


\section{Mengukir Fajar \\ Perajin Mebel Berbisnis, Berserikat dan Meraih Sertifikat Legalitas Kayu}

\section{Penyunting:}

Rika Harini Irawati

Herry Purnomo

Bayuni Shantiko 
C 2013 Pusat Penelitian Kehutanan Internasional (CIFOR)

Isi dari publikasi ini dibawah lisensi Creative Commons Attribution-NonCommercial-NoDerivs 3.0 Unported License http://creativecommons.org/licenses/by-nc-nd/3.0/

ISBN 978-602-1504-15-4

Irawati RH, Purnomo H dan Shantiko B (ed.). 2013. Mengukir fajar baru perajin mebel Jepara berbisnis, berserikat dan meraih sertifikat legalitas kayu. Bogor, Indonesia: CIFOR.

Cover foto oleh Diana Vela. Perajin Jepara mengukir relief.

Photo isi oleh koleksi pribadi dan CIFOR FVC

\section{CIFOR}

Jl. CIFOR, Situ Gede

Bogor Barat 16115

Indonesia

$\mathrm{T}+62(251) 8622-622$

F +62 (251) 8622-100

E cifor@cgiar.org

\section{cifor.org}

Kami ingin berterima kasih kepada para donatur yang telah mendukung penelitian ini melalui kontribusinya terhadap Dana CGIAR. Untuk daftar donor dapat dilihat dalam: https://www. cgiarfund.org/FundDonors

Pandangan yang diungkapkan dalam buku ini berasal dari penulis dan bukan merupakan pandangan CIFOR, para penyunting, lembaga asal penulis atau penyandang dana maupun para peninjau buku. 


\section{Daftar isi}

Daftar istilah dan akronim

Ucapan terima kasih

Pendahuluan

Bab I. Perempuan tangguh menjangkau cita $\quad 14$

1.1. Pendahuluan 14

1.2. Mencoba mendring 16

$\begin{array}{ll}\text { 1.3. Menjadi kader Posyandu } & 17\end{array}$

$\begin{array}{ll}\text { 1.4. Dari pedagang beralih menjadi petani } & 19\end{array}$

1.5. Belajar mengamplas dan mengukir $\quad 20$

1.6. Usaha mebel kecil-kecilan 22

1.7. Pendidikan anak-anak dan ibadah 25

1.8. Mengenal kegiatan proyek FVC dan manfaatnya 26

1.9. Dampak kegiatan FVC yang dirasakan sekarang dan harapan $\begin{array}{ll}\text { ke depan } & 27\end{array}$

Bab 2. Berdiri di antara pohon-pohon tumbang 30

2.1. Masa sekolah 30

2.2. Masa peralihan profesi 34

2.3. Pengalaman bekerja di bidang mebel dengan orang asing $\quad 39$

2.4. Melangkah dalam dunia baru menjadi seorang pengusahaperajin mebel

2.5. Pengalaman masa transisi 2008 dan pertemuan dengan proyek FVC CIFOR 44

2.6. Menjadi fasilitator lapangan FVC CIFOR Jepara 53

Bab 3. Hidup, berusaha, dan mendapatkan sertifikat legalitas kayu 63

3.1. Masa kecil dan remajaku 63

3.2. Bangku kuliah 65

3.3. Berkelana ke Bali dan pulang kampung 66

3.4. Investasi pada usaha mebel 68

3.5. Perjalanan usaha mebel 70

$\begin{array}{ll}\text { 3.6. Mengenal APKJ } & 74\end{array}$

3.7. Penolakan SVLK Kelompok untuk CV Mebel Jati Jepara 76 
Bab 4. Mengukir mimpi meraih prestasi $\quad 80$

$\begin{array}{ll}\text { 4.1. Riwayat hidup } & 81\end{array}$

4.2. Masa lalu sebagai tukang ukir kayu $\quad 84$

$\begin{array}{ll}\text { 4.3. Masa depan } & 87\end{array}$

4.4. Program dan pembiayaan $\quad 94$

4.5. Kesimpulan dan saran $\quad 97$

Bab 5. Tukang ukir merantau, mengembangkan usaha, dan berorganisasi

5.1. Masa kecil dan pendidikan 100

5.2. Merantau ke Jakarta dan Tangerang 103

5.3. Merantau ke Dili, Timor-Timur 104

5.4. Pulang kampung ke Jepara 119

$\begin{array}{ll}\text { 5.5. Merintis usaha di Jepara } & 121\end{array}$

5.6. Berorganisasi kemasyarakatan secara aktif 124

5.7. Penutup 134

Bab 6. Pengembangan industri mebel Jepara melalui proyek Furniture Value Chain

6.1. Perjalanan sebagai PNS di Kabupaten Jepara 136

6.2. Keterlibatan dalam Proyek Penelitian Rantai Nilai Industri Mebel yang dilaksanakan oleh CIFOR 142

6.3. Harapan-harapan untuk kemajuan ke depan 167

6.4. Beberapa hal yang dapat menjadi inspirasi dan yang harus dihindari 


\section{Daftar gambar}

\section{Gambar}

1.1. Lokasi geografis Kabupaten Jepara

1.2. Pelatihan lacak balak kayu (chain of custody) yang diadakan tahun 2009

1.3. Sertifikat SVLK yang diperoleh APKJ untuk kategori kelompok perajin

1.1. Nama saya Khoisiyah

1.2. Pekerjaan mengukir membutuhkan keahlian dan ketekunan $\quad 21$

$\begin{array}{ll}\text { 1.3. Suasana bengkel kerja di rumah saya } & 23\end{array}$

1.4. Suasana pelatihan untuk perempuan yang diadakan oleh APKJ 28

2.1. Mengikuti lomba mengukir terbanyak versi MURI di Jepara $\quad 35$

2.2. Suasana dalam pameran PPE Kemayoran Jakarta 51

2.3. Saya diminta memberikan sambutan pembukaan Knowledge Fair di Rapat Tahunan CIFOR 2010

2.4. Memfasilitasi pelatihan finishing untuk perempuan 61

3.1. Foto Latif ketika SMP 63

3.2. Menjadi pembicara dalam acara market dialog di Kedutaan Besar Republik Indonesia di London, tahun 2013

3.3. Presentasi dalam acara market dialog di Kedutaan Besar Republik Indonesia di Brussel, Belgia, tahun 2013

3.4. SVLK menghiasi ruang kerja saya

4.1. Belajar membuat patung burung

4.2. Patung ukir naga hasil karya saya yang pertama

4.3. Skema empat kebutuhan untuk menggapai mimpi

4.4. Proses mengukir patung naga dengan bantuan gergaji mesin

4.5. Katalog Indonesia Furniture Center (IFC)

4.6. Menjadi pemenang terbaik desain ukir pada China-ASEAN

International Competition and Atraction Wood Carving 2012 di Nan Ning, China

5.1. Foto Suryadi ketika kecil

5.2. Pernikahan kami di Kota Dili tanggal 2 Oktober 1993

5.3. Proses menghasilkan karya patung ukir

5.4. Pintu gerbang Sentra Industri Seni Patung dan Ukir Mulyoharjo

5.5 Set meja dan kursi akar salah satu hasil karya saya 
6.1. Berfoto bersama Dekan Fakultas Pertanian Universitas Jenderal Soedirman setelah wisuda

6.2. Berfoto bersama pejabat Bappenas dan peserta Program

Pendidikan REDS Lingkage Indonesia-Belanda sebelum keberangkatan ke Rotterdam, Belanda

6.3. Mengantar Dr. Ogenis Brillhante, Staf Pengajar IHS Erasmus University Rotterdam Belanda ke Desa Troso

6.4. Kunjungan tim peninjau ACIAR ke lokasi penanaman JUN yang merupakan inisiasi proyek FVC 


\section{Daftar istilah dan akronim}

ACIAR Australian Centre for International Agricultural Research

AMKRI Asosiasi Mebel Kayu dan Rotan Indonesia

APKJ

Asosiasi Pengrajin Kecil/Kayu Jepara

Asmindo

Asosiasi Industri Permebelan dan Kerajinan Indonesia

Bakosurtanal

Badan Koordinasi Survei dan Pemetaan Nasional

Balitbanghut

Badan Penelitian dan Pengembangan Kehutanan

Bappeda

BPEN

Badan Perencana Pembangunan Daerah

CIFOR

Badan Pengembangan Ekspor Nasional

Disperindag

Center for International Forestry Research

FF

Dinas Perindustrian dan Perdagangan

FVC

Field Facilitator (Fasilitator lapangan)

GPS

Furniture Value Chain

IFFINA

Global Positioning System

IPB

International Furniture and Craft Fair Indonesia

Institut Pertanian Bogor

IPNU

Ikatan Pemuda Nahdhlatul Ulama

IWCS

International Wood Culture Society

Javlec

Java Learning Center

JFDC

Jepara Furniture Design Centre

JTTC

JUN

Jepara Trade and Tourism Centre

Kadinda

Jati Unggul Nusantara

Kamar Dagang dan Industri Daerah 
LC Letter of Credit

NESO Netherlands Education Support Office

OCI Organisasi Centra Industri

Orari Organisasi Radio Amatir Indonesia

PDRB Produk Domestik Regional Bruto

Pemda Pemerintah Daerah

PNS Pegawai Negeri Sipil

PKK Pembinaan Kesejahteraan Keluarga

Posyandu Pos Pelayanan Terpadu

PPE

Pameran Produk Ekspor

RA Research Assistant

SKPD Satuan Kerja Perangkat Daerah

STTDNU Sekolah Tinggi Teknologi dan Desain Nahdlatul Ulama

SVLK

Sistem Verifikasi Legalitas Kayu

UKM Usaha Kecil Menengah

UMKM Usaha Mikro Kecil dan Menengah 


\section{Ucapan terima kasih}

Ucapan terima kasih dan penghargaan setinggi-tingginya kami sampaikan kepada berbagai pihak yang telah berperan atas penerbitan buku ini. Terima kasih kami ucapkan kepada ACIAR (Australian Centre for International Agricultural Research) yang telah mendanai kegiatan proyek Furniture Value Chain-CIFOR dan para penulis kisah inspiratif (Khoisiyah, Sulthon, Latif, Legiman, Suryadi, dan Adi Nugroho) yang telah bersedia meluangkan waktunya untuk berbagi pengalaman dan perjalanan menuju kesuksesan di bidang permebelan. Seluruh tulisan dalam buku ini adalah pandangan individu penulis dan tidak mewakili pandangan atau kebijakan donor serta lembaga-lembaga lain yang terlibat.

Secara khusus kami berterima kasih kepada Andrew Wardell, Gideon Suharyanto, Dina Hubudin, Bayuni Shantiko dari CIFOR; Rachman Efendi dan Nunung Parlinah dari Balitbang Kementerian Kehutanan; Dodik Ridho Nurrohmat, Bahruni dan Efi Yuliati Yovi dari IPB; serta para mitra proyek FVC di Jepara; rekan-rekan dari Forum Rembug Klaster Industri Furnitur Jepara, Asosiasi Pengrajin Kayu Jepara, Asmindo Jepara, Dinas Kehutanan Jepara dan Pemerintah Daerah Jepara yang telah mendukung proses terciptanya buku ini. Dukungan sangat berarti juga kami terima dari para rekanan dan mitra proyek yang telah meluangkan waktu untuk mendiskusikan isi tulisan, serta memberikan umpan balik kepada penyunting untuk perbaikan tulisan ini.

Kami menyadari masih banyak kekurangan dalam penulisan buku ini. Oleh karena itu, kami sangat terbuka untuk berbagai komentar, masukan, serta saran demi perbaikan penulisan selanjutnya.

Para penyunting 



\section{Pendahuluan}

CIFOR adalah Pusat Penelitian Kehutanan Internasional yang merupakan puncak perwujudan komitmen dari lebih 30 pemerintah negara-negara di dunia yang peduli terhadap masa depan hutan tropis setelah Earth Summit di Rio de Janeiro, pada tahun 1992. Pemerintah Indonesia melalui Menteri Luar Negeri Ali Alatas dan Menteri Kehutanan Djamaluddin Suryohadikusumo memfasilitasi berdirinya CIFOR pada tahun 1993 sebagai organisasi antarpemerintah dengan kantor pusat di Bogor. CIFOR melakukan penelitian tentang pengelolaan hutan, konservasi, perubahan iklim, kehutanan masyarakat dan industri hasil hutan, serta perdagangan dan investasi di Asia, Afrika, dan Amerika Latin.

CIFOR mempunyai perhatian khusus pada industri yang berbasis masyarakat, hutan, dan budaya lokal seperti mebel. Kelestarian industri mebel bermanfaat dalam memberi insentif kepada masyarakat untuk menanam pohon, menyediakan lapangan kerja dan penghidupan bagi masyarakat, pengembangan budaya lokal, dan penyimpanan karbon di luar hutan.

\section{Kondisi geografis Kabupaten Jepara}

Kabupaten Jepara mempunyai luas sekitar $100.413,189$ ha yang meliputi 16 kecamatan, 183 desa, dan 11 kelurahan (Gambar 1.1). Di sebelah utara 


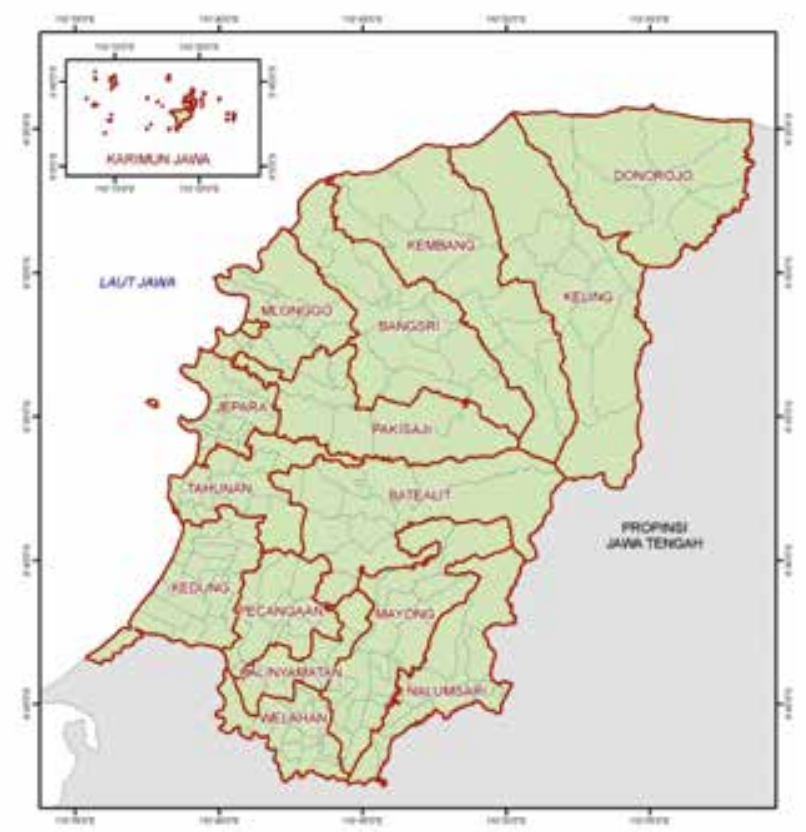

\section{Gambar 1.1. Lokasi geografis Kabupaten Jepara}

dan barat berbatasan dengan Laut Jawa, di sebelah selatan dengan Kabupaten Demak dan di sebelah timur dengan Kabupaten Pati dan Kabupaten Kudus. Lebih dari 95\% wilayahnya berada di daratan Pulau Jawa dan sisanya merupakan gugusan pulau yang dikenal dengan Kepulauan Karimunjawa.

Jepara memiliki topografi antara 0-1.301 m di atas permukaan laut dengan daerah dataran tinggi yaitu di sekitar Gunung Muria dan Gunung Clering, dataran rendah, dan pantai. Menurut Peta Rupa Bumi Indonesia skala 1:25000 dari Bakosurtanal (Badan Koordinasi Survei dan Pemetaan Nasional), tutupan lahan di Kabupaten Jepara diklasifikasikan dalam 10 kelas yakni: persawahan $(32,56 \%)$, perumahan $(18,82 \%)$, perkebunan $(18,82 \%)$, tegalan/ladang $(11,74 \%)$, hutan $(5,80 \%)$, belukar $(2,56 \%)$, tubuh air/danau/ rawa $(1,42 \%)$, sungai $(0,66 \%)$, padang rumput $(0,41 \%)$ dan hutan bakau 
(0,03\%). Penduduk Kabupaten Jepara sedikit di atas satu juta jiwa, dengan proporsi yang hampir seimbang antara laki-laki dan perempuan. Kepadatan penduduk tersebar di sebelah barat dan selatan kabupaten. Di sebelah timur, yaitu di sekitar Gunung Muria dan di pantai di bagian utara, di sekitar Gunung Clering yang merupakan daerah hutan dengan kepadatan penduduk tidak begitu tinggi. Keberadaan infrastruktur cukup baik yang ditandai dengan kepadatan jalan yang tersebar merata. Daerah dengan kepadatan jalan rendah ada di utara dan timur dengan jenis tutupan lahan adalah hutan. Sedangkan untuk kepadatan jalan rendah yang ada di sebelah selatan adalah karena daerah tersebut merupakan rawa dan tambak.

\section{Industri mebel Jepara}

Sejak ratusan tahun yang lalu, industri mebel dan ukir di Jepara telah menjadi tulang punggung perekonomian kabupaten ini. Oleh karena itu, data keberadaan industri mebel dapat mewakili gambaran tentang situasi industri yang sebenarnya.

Mebel merupakan salah satu dari empat komoditas ekspor utama Indonesia selain minyak dan gas bumi. Tiga komoditas ekspor lainnya adalah kelapa sawit, garmen, dan karet. Ekspor mebel Indonesia bernilai 1,4 miliar dolar AS atau setara dengan Rp 13 triliun. Perdagangan mebel dunia tahun 2010 mencapai 135 miliar dolar AS atau sekitar 1\% dari total perdagangan dunia di bidang manufaktur. Sebesar 54\% dari ekspor mebel berasal dari negara sedang berkembang termasuk Indonesia, Malaysia, Meksiko, Polandia, dan China. Rasio impor dengan konsumsi melebihi 31\%. Mebel dari kayu jati dan mahoni paling diminati di dunia karena faktor kekuatan dan estetika yang dimiliki oleh kedua jenis kayu tersebut.

Indonesia sangat berkepentingan dengan keberlanjutan industri mebel karena penyerapan tenaga kerja yang besar, penguasaan teknologi dan tenaga terampil yang berpotensi, serta memiliki nilai tambah yang tinggi sekaligus berbahan baku dari sumber yang bisa terbarui, yaitu hutan. Selain berbagai alasan ini, peran mebel di Indonesia juga merupakan bagian dari budaya dan peradaban masyarakat. Jepara diprakirakan menyumbang $10 \%$ dari total ekspor mebel Indonesia tahun 2010 berdasarkan data Dinas Perindustrian 
dan Perdagangan Jepara. Dari sisi perekonomian lokal, industri mebel dan ukiran kayu Jepara menyumbang 26\% ekonomi lokal dan 10\% dari total ekspor mebel Indonesia.

Pada tahun 2010, terdapat 11.981 unit usaha mebel di Jepara yang terdiri atas $92 \%$ unit usaha kecil, $6 \%$ unit usaha menengah, dan $2 \%$ unit usaha skala besar, dengan jumlah pekerja lebih dari 100.000 orang. Jika dibandingkan dengan data tahun 2005 yang dinyatakan dalam Roda, dkk. (2007), bahwa terdapat 15.000 unit usaha mebel dan kerajinan kayu Jepara, maka angka ini menggambarkan penurunan. Mebel tidak hanya merupakan bagian sangat penting dari perekonomian Jepara, tetapi juga merupakan denyut nadi dan budaya masyarakatnya. Mereka meyakini bahwa keahlian dan keterampilan membuat mebel merupakan warisan sejarah yang harus terus dijaga kelestariannya. Mebel Jepara dikembangkan dalam sejarah penciptaan yang panjang. Keterampilan membuat mebel telah dimiliki oleh orang Jepara sejak berabad yang lalu yaitu sejak zaman Ratu Shima (abad VII), Ratu Kalinyamat (abad XVI), dan R.A. Kartini (abad XIX). Para leluhur mereka mewariskan keterampilan itu secara turun-temurun dalam suatu sistem pewarisan keterampilan dan proses pembelajaran yang unik.

Brak adalah tempat proses produksi mebel yang umumnya berskala kecil. Pada tahun 2010, terdapat 8.281 brak, yang setiap unit brak mengonsumsi $104,15 \mathrm{~m}^{3}$ kayu per tahun. Konsumsi bahan baku kayu untuk brak skala kecil dan mikro sekitar 99,27 $\mathrm{m}^{3}$ per tahun, sedangkan skala menengah dan besar masing-masing $282 \mathrm{~m}^{3}$ dan $1.115 \mathrm{~m}^{3}$ per tahun. Karena itu total prakiraan konsumsi kayu yang diserap oleh industri mebel dan kerajinan kayu Jepara adalah sebesar $863.147 \mathrm{~m}^{3} /$ tahun. Sejumlah $82 \%$ brak menjual produknya khusus untuk pasar domestik dan hanya sekitar 9\% untuk kebutuhan pasar ekspor. Sisanya menjual untuk ekspor dan domestik. Dari $82 \%$ yang menjual untuk pasar domestik juga ada kemungkinan kemudian dijual untuk pasar ekspor melalui saluran pemasaran yang lain. Sekitar 22\% brak yang masih beroperasi saat ini didirikan pada tahun 1998-2000, di masa ketika terjadi ekspor mebel kayu melonjak. 
Pasokan bahan baku kayu tertinggi berasal dari hutan rakyat di Jawa Tengah dan sekitar 11,47\% kebutuhan bahan baku dipasok dari Sulawesi dan Sumatera. Besarnya persentase pasokan bahan baku sangat ditentukan oleh mutu kayu dan harga. Rasio antara ketersediaan bahan baku dan kebutuhan bahan baku yang tinggi membuat ketergantungan produksi mebel Jepara terhadap pasokan bahan baku kayu dari luar Jepara. Sekitar 93,36\% pasokan bahan baku kayu berasal dari luar Jepara sangat tinggi. Hal ini membuat kelangsungan usaha mebel Jepara rentan. Selain itu, kendali harga bahan baku semakin rendah sehingga dapat menurunkan kemampuan daya saing.

\section{Riset aksi yang dilakukan CIFOR dan mitranya di Jepara}

Riset aksi (action research) untuk meningkatkan efisiensi rantai nilai dan meningkatkan penghidupan perajin mebel (Furniture Value Chains atau FVC) adalah sebuah proyek penelitian yang didanai oleh Pusat Penelitian Pertanian Internasional Australia (Australian Centre for International Agricultural Research atau ACIAR) yang dilaksanakan sejak tahun 2008 hingga tahun 2013. Tujuan utama riset ini adalah untuk mengupayakan terciptanya perbaikan struktur dan fungsi industri mebel Jepara, dari perolehan bahan baku kayu hingga proses pemasaran ke konsumen.

Peneliti, aktor lokal, dan para pihak terkait menilai efisiensi rantai nilai mebel yang terjadi saat ini, kemudian berusaha mengembangkan dan melaksanakan rencana untuk peningkatan efisiensi, kapasitas institusi, dan nilai tambah mebel. Perbaikan dilakukan dalam bentuk kebijakan pemerintah dan peningkatan efisiensi dalam rantai nilai mebel, agar dapat menghidupi ribuan pengusaha mebel, mempertahankan lapangan kerja, meningkatkan penghasilan perajin skala kecil, dan memberikan mereka peran yang lebih besar di dalam rantai nilai. Proyek Penelitian FVC dilaksanakan CIFOR bekerja sama dengan Pemerintah Daerah (Pemda) Jepara, Badan Penelitian dan Pengembangan Kehutanan (Balitbanghut) Kementerian Kehutanan, dan Fakultas Kehutanan Instititut Pertanian Bogor (IPB). 
Pelaksanaan riset aksi ini mencakup serangkaian kegiatan refleksi, perencanaan, tindakan, dan pemantauan yang dilakukan berulang-ulang berdasarkan prinsip riset aksi yang dikemukakan oleh Henocque dan Denis (2001) serta Selener (1997). "Refleksi" merupakan pengkajian dan pemahaman yang mendalam tentang industri mebel Jepara, sedangkan "perencanaan" merupakan gambaran kegiatan yang akan dilakukan untuk meningkatkan kinerja perajin dan pihak terkait dalam industri mebel Jepara. Perencanaan ini kemudian dilanjutkan dengan "tindakan" nyata di lapangan, serta melakukan "pemantauan" atas dampak dan akibat dari tindakan yang diambil. Kemudian hasil dari pemantauan dijadikan refleksi untuk kegiatan selanjutnya. Siklus ini kemudian berputar kembali. Proses penulisan dan penyebaran buku ini merupakan bagian dari refleksi atas keadaan mebel di Jepara berdasarkan pandangan para aktor yang terlibat langsung dalam menjalankan usaha dan dalam bidang lain di industri mebel Jepara.

Tim peneliti FVC melakukan riset aksi ini dengan mencoba menjadi bagian dari masyarakat mebel Jepara. Beragam diskusi dan pertemuan dengan banyak pihak terkait telah dilakukan selama lima tahun pelaksanaan penelitian ini di Jepara. Begitu juga beragam pelatihan, survei, serta bertemu langsung dengan pelaku usaha mebel dilakukan tim peneliti agar dapat lebih menyelami apa yang sebenarnya terjadi di Jepara. Menjadi pihak luar yang mencoba memahami hal yang terjadi tidak dapat dicapai hanya dengan membaca laporan atau data. Menjalin komunikasi dan berteman dengan banyak pihak menjadi tantangan tersendiri bagi kami, anggota tim peneliti untuk dapat diterima oleh semua pihak.

Walaupun tujuan penelitian ini berfokus pada peningkatan usaha kecil, kami juga harus mampu bekerja sama untuk saling menguntungkan dengan pengusaha besar dan asosiasinya. Kami juga harus mampu bersinergi dengan upaya-upaya yang telah dilakukan oleh pemerintah daerah dan Asosiasi Industri Permebelan dan Kerajinan Indonesia (Asmindo) dalam rangka meningkatkan kemajuan industri mebel. Kami juga berusaha memperkuat peran pemerintah daerah dan menjembatani komunikasi antara pemerintah dan dunia usaha. Kami juga bekerja sama dengan media massa, terutama 
radio untuk menyampaikan pesan-pesan dan produk yang kami hasilkan kepada seluruh perajin Jepara.

Tim peneliti mencoba untuk tidak hanya terpaku pada pelaksanaan riset secara standar, tidak terjebak dalam beragam survei, pertemuan, lokakarya, serta pelatihan yang dilakukan. Kami mencoba memfasilitasi aksi-aksi sebagai bagian dari upaya menguji hipotesis yang terformulasikan saat proses 'refleksi' berlangsung. Jika aksi yang dilakukan mampu membawa hasil yang baik, maka perubahan perilaku (menjadi lebih baik) juga akan terjadi. Ini sejalan dengan definisi riset aksi yang menekankan pada peningkatan pemahaman dan perubahan perilaku yang terjadi pada saat yang hampir bersamaan.

Ada empat skenario yang dikerjakan untuk meningkatkan kehidupan usaha mebel skala kecil yaitu: berkolaborasi dengan pihak pemasok bahan baku (collaborating down), peningkatan ke tingkatan rantai nilai yang lebih tinggi (moving up), produk hijau (green product), dan asosiasi (association). Skenario pertama di mana para perajin kecil berkolaborasi dengan pedagang dan petani hutan, diharapkan dapat mengantisipasi terjadinya kelangkaan bahan baku, keterlambatan pengiriman kayu, dan rendahnya kualitas bahan baku kayu yang memengaruhi kualitas mebel.

Skenario ke dua adalah moving up, di mana kami meningkatkan kapasitas perajin sehingga mereka tidak hanya memproduksi mebel tetapi juga naik ke tingkatan rantai nilai yang lebih tinggi yaitu sebagai pemasar. Kegiatan FVC memberi pelatihan pemasaran secara langsung maupun online melalui portal pemasaran, yaitu www.javamebel.com. Para perajin juga difasilitasi untuk turut serta dalam pameran baik yang bertaraf nasional maupun internasional. Dengan demikian mereka dapat berinteraksi secara langsung dengan pembeli dan calon pembeli, memiliki pengetahuan dan keterampilan mengenai cara berkomunikasi serta menindaklanjuti perkenalan yang terjalin.

Skenario ke tiga adalah green product. Skenario ini dilakukan untuk menghasilkan produk bersertifikat (furnitur berlabel ramah lingkungan hidup/ecolabel) atau green product yang disyaratkan oleh banyak pembeli 
luar negeri. Menghasilkan produk bersertifikat memerlukan koordinasi multipihak dari petani hutan, pedagang kayu, produsen, dan penjual mebel. Skenario green product ini sejalan dengan inisiatif pemerintah tentang Sistem Verifikasi Legalitas Kayu (SVLK) dan menunjang skema indikasi geografis Mebel Ukir Jepara (MUJ) yang sedang digalakkan oleh Pemerintah Jepara.

Kemudian skenario ke empat adalah association. Skenario ini dimaksudkan agar para perajin membentuk dan bersatu dalam kelompok atau asosiasi. Skenario ini juga bertujuan agar terjadi pengorganisasian bagi usaha kecil yang membantu mereka untuk mengakses lembaga keuangan dan pasar. Asosiasi atau koperasi adalah bentuk umum dari skenario ini. Skenario ini sudah terwujud dalam bentuk Asosiasi Pengrajin Kecil Jepara (APKJ) yang harus terus menerus diperkuat, misalnya dengan mendirikan koperasi. Selain sebagai sarana untuk menunjang usaha mereka dalam hal

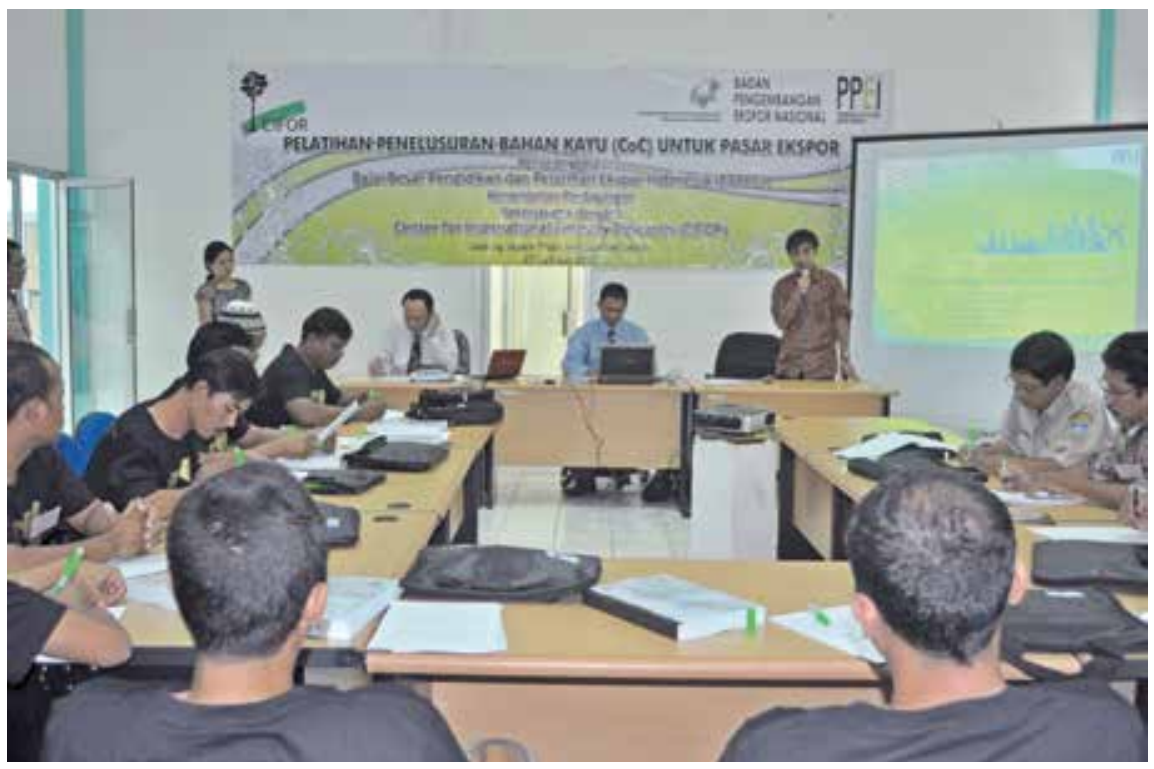

Gambar 1.2. Pelatihan lacak balak kayu (chain of custody) yang diadakan tahun 2009 
permodalan, koperasi juga bermanfaat untuk mengakses bantuan pinjaman dari pemerintah atau lembaga keuangan yang hanya bisa tersalurkan melalui koperasi.

Di samping empat skenario tersebut, kami bekerja sama dengan para pihak di Jepara terutama Bappeda (Badan Perencana Pembangunan Daerah), akademia, Asmindo (Asosiasi Industri Permebelan dan Kerajinan Indonesia), APKJ, Kadinda (Kamar Dagang dan Industri Daerah) untuk mengembangkan roadmap atau peta jalan industri mebel di Jepara 20132023. Peta jalan ini setelah didiskusikan dengan para pihak, termasuk bupati dan DPRD Jepara, akan diusulkan menjadi peraturan daerah (Perda) di Kabupaten Jepara.

Sejalan dengan skenario green product, FVC mengadakan pelatihan lacak balak kayu atau chain of custody (CoC) tanggal 27-29 Juli 2009. CIFOR, IPB dan Litbanghut bekerja sama dengan Badan Pendidikan dan Pelatihan Ekspor Indonesia (BPPEI) memberikan teori dan praktik CoC. FVC kemudian mengembangkan penilaian mandiri CoC bagi para anggota $\mathrm{APKJ}$. Pelatihan CoC ini dilanjutkan dengan keikutsertaan anggota APKJ pada pelatihan berikutnya yang diselenggarakan oleh Lembaga Ekolabel Indonesia (LEI) di UGM Yogyakarta tanggal 21-22 Desember 2009. Pelatihan ini melingkupi istilah sertifikasi produk kayu, berbagi pengalaman dengan perusahaan ekspor yang sudah menggunakan sertifikasi tersebut dan sistem wajib sertifikasi dari pemerintah sebagai tindak lanjut dari VPA (Voluntary Partnership Agreement) antara Pemerintah Indonesia dengan masyarakat Uni Eropa tentang legalitas produk kayu yang diekspor Indonesia ke Uni Eropa.

Anggota APKJ mengikuti pelatihan-pelatihan serupa pada tahun 2010 sebagai tindak lanjut VPA yang kemudian menjadi SVLK. Pada tahun 2011, APKJ mendapatkan sosialisasi SVLK di hotel Jepara Indah yang difasilitasi oleh MFP-DfID (Multi-stakeholder Forestry Programme Department for International Development UK) bekerja sama dengan Yayasan Hutan Tropis. Pada awal 2012, APKJ mengikuti pelatihan SVLK yang diselenggarakan oleh MFP-DfID. Pada bulan Oktober 2012, Javlec (Java Learning Center) yang 


\section{Sertifikat}

Standar

No. Registrasi Sertifikat

Pemikk Sertifikat:

Ruang Lingrup:

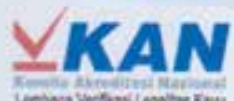

Leboga Wrbas Legatas Kay incrous of
Peraturan Direktur Jenderal Bina Usaha Kehutanan Nomor: P.8/VI-BPPHH/ 2012 tanggal 17 Desember 2012 Tentang Standar dan Pedoman Pelaksanaan Ponilaian Kinerja Pengelolaan Hutan Produksi Lestari (PHPL) dan Verifikasi Legalitas Kayu (VLK)

824303130023

PT TUV Rhenland Indonesia mensertifcas:

ASOSIASI PENGRAJIN KECIL JEPARA (APKJ)

Kantor dan Lokasi Pobris:

Gedung JTC. JI. Raya Jepara - Kudus KM 11,5 Pecangan Jepara. Propinsi Jawa Tengah - Indonesia

Akta Notaris Pejabat Akta Tanah HA Qomar Nasikh, SH Nomor 15 Tanggal $10-07-2009$

Kelompok Industri Rumah TanggaPengraejn dengan Anggota Kelompok Sertikasi seperti tercantum dalam Lampiran Sertikicat ini.

Terbikti telah memenuhi Standar Verificasi Legaltas Kayu sesuai Peraturan Drektur Jenderal Bina Usaha Kehutanan Nomor P 8/V1-8PPHH/2012 tanggal 17 Desember 2012 Lampiran 2.7 Pedoman Pelaksanaan Venfikasi Legaltas Kayu Pada Industri Rumah TangoalPengrajin

Masa Berlaku: Sertikat ini berlaku dari 30-05-2013 sampai 29-05-2019.

Jakarta. 30-05-2013

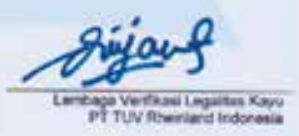

wwwtevicom

\section{Gambar 1.3. Sertifikat SVLK yang diperoleh APKJ untuk kategori kelompok perajin}


bekerja sama dengan MFP-DfID menawarkan untuk mendampingi atau memfasilitasi APKJ supaya bisa mendapatkan sertifikat SVLK secara bersama.

Lewat pendampingan ini, 35 anggota APKJ mengikuti proses audit SVLK. Jumlah ini kemudian menyusut menjadi 15 anggota dan akhirnya menjadi 9 orang. Penyusutan ini terjadi karena kesulitan perajin kecil dalam memenuhi kelengkapan dokumentasi yang diperlukan. Akhirnya pada awal Mei 2013, group kami (APKJ) diaudit oleh TUV Rheinland selama tiga hari dengan hasil baik dan lulus. Kelulusan ini ditandai dengan Sertifikat SVLK tertanggal 30 Mei 2013 dan berlaku selama enam tahun.

\section{Aktor lokal}

Peran para aktor lokal sangat penting dalam pelaksanaan riset aksi. Mereka sudah lama berkutat dalam dinamika industri mebel dan tetap berusaha meski jatuh bangun dalam mengembangkan industrinya. Buku ini mengungkapkan beberapa pengalaman pribadi para pelaku industri mebel, dari perajin laki-laki dan perempuan serta pengambil kebijakan. Cerita-cerita ini memberikan perspektif nyata mengenai mebel Jepara dari para aktor industri di lapangan.

Khoisiyah adalah perempuan yang aktif di masyarakat dan juga menekuni dunia mebel di Jepara. Darah Jepara yang mengalir dalam tubuhnya, membuatnya selalu ingin belajar tentang mebel, terutama dalam hal mengukir. Perempuan adalah makhluk yang gesit melakukan tugas ganda; dan ini dibuktikan dengan cerita Khoisiyah yang dalam kehidupan sehari-harinya memiliki berbagai peran dan tugas pekerjaan; sebagai ibu rumah tangga, aktif di masyarakat sebagai kader PKK dan Posyandu serta menjalankan usaha mebel sekaligus beragam wirausaha lain yang dilakukan bersama suaminya. Pelatihan dan kegiatan dari FVC yang pernah diikutinya semakin membuka mata dan kesempatannya untuk lebih memajukan usaha demi kehidupan keluarga dan lingkungannya.

Sulthon termasuk sedikit generasi muda yang memutuskan untuk meneruskan tradisi mebel Jepara. Dia berasal dari keluarga petani dan pernah menggeluti berbagai profesi di luar bidang mebel dan ukiran seperti 
pegawai LSM lokal, pengajar kursus bahasa Inggris, dan penjual produk multilevel marketing (MLM). Sampai akhirnya kehidupannya mulai berubah setelah dia memutuskan untuk menempuh kuliah di jurusan desain. Bekal ilmu desain dan kemampuan menggambar mengantarkan Sulthon dari satu perusahaan ke perusahaan lain hingga membuka pergaulannya dengan para pembeli dari berbagai negara. Memutuskan untuk terjun lebih dalam ke dunia mebel merupakan keputusan yang cukup berani. Kemudian setelah bergabung dengan APKJ, Sulthon menyadari manfaatnya, antara lain pengalaman menyiapkan dan mengelola keikutsertaan dalam pameran produk mebel dalam skala nasional dan internasional. Kemampuannya menggabungkan berbagai ilmu yang diperoleh di bangku kuliah, mengikuti berbagai pelatihan dan berinteraksi dengan banyak kalangan menjadikan Sulthon sebagai pribadi sekaligus perajin dengan kemampuan yang unik.

Abdul Latif atau biasa dipanggil Latif, adalah pengusaha mebel yang dilahirkan dari keluarga petani dan berlatar belakang pendidikan keguruan. Dia terjun ke dunia mebel awalnya sebagai sopir colt pengangkut barang ke gudang, lalu memberanikan diri untuk berinvestasi kayu dan menjadi makelar mebel hingga dan akhirnya bisa menjadi eksportir. Perjalanan panjang yang dilaluinya tidak mudah dan selalu lancar, tetapi penuh perjuangan dan risiko yang harus dihadapi. Latif pun tergabung sebagai anggota APKJ. Meski kadang merasa tidak memiliki kemampuan yang mumpuni dalam berorganisasi, ia tetap memegang peranan penting dalam perjalanan penting APKJ, terutama ketika sedang menghadapi pameran. Keberaniannya untuk tetap mengikuti SVLK meski dengan biaya sendiri, perlu diapresiasi dan ditularkan semangatnya kepada perajin mebel lain di Jepara dan Indonesia.

Legiman Arya adalah perajin kecil dengan semangat yang besar. Dia menceritakan bagaimana awal menjadi seorang pengukir; mulai dari belajar dengan cara mengamati orang yang lebih terampil hingga belajar pada seorang ahli di luar daerah Jepara. Gaya ukiran yang dihasilkannya memang unik, karena merupakan paduan antara seni ukir dengan menggunakan gergaji dan ukiran halus khas Jepara. Kisahnya juga menggambarkan keuletan dan ketangguhannya dalam menghadapi setiap tantangan, serta 
cara menghadapi masalah dalam pekerjaan dengan cara berpikir prestasi. Semangat dan keberanian Legiman disalurkan melalui berbagai macam organisasi yang diikutinya, salah satunya adalah APKJ. Harapannya, organisasi yang diikuti sekarang akan membuka jalan demi terciptanya kemajuan industri mebel Jepara di masa mendatang.

Suryadi adalah seorang perajin patung yang juga memulai usahanya dari bawah. Selain memiliki keterampilan mengukir yang mumpuni, ia juga memiliki kemampuan elektro yang mampu menghidupi keluarganya sebelum terjun mendalami industri mebel dan patung. Pekerjaan yang berhubungan dengan mebel justru dimulai bukan di Jepara, namun di ujung Timur Indonesia (waktu itu) yaitu di Dili, Timor-Timur. Keberanian untuk merantau meski sempat ditangisi keluarga, tidak membuat semangatnya meluntur. Bahkan bisa dibuktikan bahwa setelah pulang dari rantau, secara perlahan ia bisa merangkak naik memulai usaha mebelnya sendiri bahkan berhasil menyatukan para perajin di daerah sekitarnya melalui wadah sentra dan koperasi. Koperasi yang digagas olehnya bahkan bisa memperoleh kepercayaan dari bank dan berhasil menyalurkan modal usaha bagi para perajin di sekitarnya.

Adi Nugroho adalah seorang Pegawai Negeri Sipil (PNS) yang sekarang berkedudukan di Bappeda Jepara. Keterlibatannya dalam project FVC bisa dikatakan sudah berlangsung sebelum proyek ini dimulai. Dalam tulisannya, ia mengakui bahwa banyak terdapat perbedaan cara yang dilakukan oleh seorang birokrat dengan cara kerja tim peneliti FVC, terutama dalam pengumpulan dan pengolahan data. Namun perbedaan ini bukan untuk dijadikan sebagai bahan perdebatan panjang, sebaliknya justru dapat digunakan sebagai pembuka wawasan dan sebagai bahan acuan dalam pelaksanaan tugasnya sebagai birokrat di masa mendatang. 


\section{Babl.}

\section{Perempuan tangguh menjangkau cita}

Oleh: Khoisiyah

\subsection{Pendahuluan}

Nama saya Khoisiyah, lahir tanggal 7 Mei 1965, di Desa Jondang, Kecamatan Kedung, Kabupaten Jepara. Saya menempuh pendidikan dasar di SD Negeri Bugel 3 lalu melanjutkan ke Madrasah Tsanawiyah Menganti. Setelah lulus, kemudian saya melanjutkan ke Madrasah Aliyah (setingkat SMA) Menganti.

Saya merasa masa kecil saya tidak seperti anakanak lainnya. Ketika teman-teman sebaya saya menjalani masa kecilnya dengan bermain dan

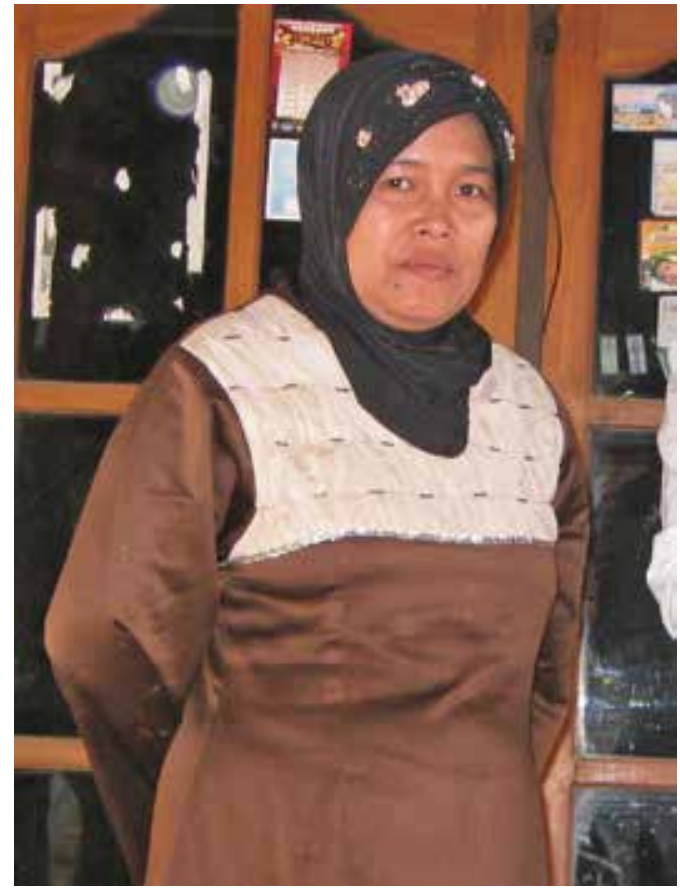

Gambar 1.1. Nama saya Khoisiyah 
berbahagia seperti bermain pasar-pasaran, petak umpet, serta permainan lainnya, saya harus membantu orang tua bekerja di pasar. Hasil upah bekerja di pasar saya kumpulkan untuk bisa memenuhi kebutuhan sendiri tanpa harus meminta kepada orang tua lagi. Perjalanan usaha saya dimulai dengan usaha kredit barang kebutuhan rumah tangga. Saya memulai usaha kredit ini tahun 1987 dengan modal yang sangat terbatas, demi untuk menambah penghasilan. Untuk usaha ini saya berjuang kesana-kemari mencari konsumen agar usaha tetap berjalan.

Sejak menikah, saya juga menggarap sawah. Hasil garapan sawah ini sedikit demi sedikit saya kumpulkan sampai akhirnya mempunyai cukup modal untuk memulai usaha mebel kecil-kecilan. Usaha mebel ini saya mulai tahun 2005. Saya juga belajar mengukir, mengamplas dan belajar mengenal produk mebel untuk di dalam dan di luar rumah. Saya merasa bahwa usaha mebel ini mengasyikkan dan peluang usahanya menjanjikan. Seperti halnya orang Jepara lainnya, saya pun sangat mencintai usaha mebel.

Hingga saat ini, saya sudah mengirimkan produk mebel saya ke beberapa kota di Indonesia. Usaha saya ini didukung sepenuhnya oleh keluarga dan terus berkembang hingga memiliki konsumen di beberapa provinsi di Indonesia. Saat ini, saya sudah mempunyai dua anak laki-laki. Meskipun saya tidak bersekolah sampai jenjang yang tinggi, jiwa wirausaha saya telah menjadikan saya berkembang. Saya bukan wanita lemah yang hanya bisa menadahkan tangan pada suami, namun saya mempunyai tekad kuat untuk maju.

Setelah menamatkan sekolah di Madrasah Aliyah Menganti, saya tidak melanjutkan sekolah karena biaya yang besar untuk masuk ke perguruan tinggi. Namun saya harus ikut suatu organisasi agar saya tidak hanya berdiam di rumah dan menjadi gadis yang kurang pergaulan. Bersama teman-teman, saya akhirnya bergabung dalam Ikatan Pemuda Nahdlatul Ulama atau yang sekarang lebih dikenal dengan sebutan IPNU. Melalui perkumpulan ini, saya mendapat teman yang cukup banyak dan dari berbagai kalangan serta dari desa yang berbeda. Ilmu yang saya dapatkan tentang religi pun cukup untuk 
mengantarkan saya untuk bekerja sebagai guru TPQ (Taman Pendidikan Al Quran).

Saya kenal banyak guru di desa saya yang akhirnya mengantarkan saya untuk menjadi pendidik di madrasah di desa saya. Saat itu saya berpikir, "Mengapa tidak saya coba saja untuk menjadi guru madrasah? Saya cukup percaya diri dan memiliki kemampuan untuk mengajar anak-anak mengaji.” Akhirnya, saya menjadi guru di madrasah desa. Pengalaman ini sangat mengasyikkan bagi saya. Bertemu dengan anak-anak yang ceria, berbagi ilmu dengan para guru madrasah, serta mengajar anak-anak mengaji, sangat membuat saya senang dan bersemangat dalam hidup. Setelah menjadi pengajar di madrasah selama dua tahun, akhirnya saya memutuskan berhenti setelah melangsungkan pernikahan. Alasannya sederhana, honor yang saya dapatkan tidak cukup untuk membantu menghidupi rumah tangga.

\subsection{Mencoba mendring}

Ketika kira-kira berumur 18 tahun, saya bertekad untuk mandiri dan tidak menyusahkan orang tua lagi. Untuk itu saya sedikit demi sedikit mengumpulkan uang jajan dan upah yang diterima ketika mengajar serta membantu orang tua untuk digunakan sebagai modal awal usaha. Usaha yang terpikir oleh saya adalah berjualan barang dengan cara kredit. Hal ini didasari oleh hobi berbelanja saya dan kadang barang yang saya beli disukai oleh teman-teman dan tetangga. Berjualan seperti ini biasa dikenal dengan mendring yaitu pembelian suatu barang (pakaian, peralatan dapur, elektronik dan lain sebagainya dengan sistem angsuran yang ditagihkan setiap minggu). Biasanya jangka waktu kredit ini lamanya tiga bulan. Saya lalu berkeliling kampung dengan bermodalkan buku catatan angsuran dan pembelian.

Saya menawarkan kepada para tetangga untuk memesan apa saja yang mereka inginkan dan membayarnya secara bertahap. Setiap minggu saya berkeliling kampung menemui pelanggan untuk menarik uang angsuran mereka. Pesanan mereka bermacam-macam, dari baju untuk anaknya sampai panci, kompor, tikar, gelas, dan perabotan rumah tangga lainnya. Namun kendala yang saya dapatkan begitu banyak, antara lain mereka yang mogok saat angsuran, sehingga modal berjualan terganggu. Ada juga yang belum 
selesai membayar sudah kabur merantau ke luar kota. Pekerjaan ini tetap saya lanjutkan ketika menikah.

Saya tergolong menikah di usia muda. Saya bertemu suami ketika sedang berkeliling kampung untuk menarik angsuran pada tetangga. Saat itu saya sedang ke rumah salah satu pelanggan, kemudian dia menyapa dan saya pun jatuh hati pada pandangan pertama. Dia pun kemudian sering datang ke rumah dan orang tua saya pun menyukainya karena sifatnya yang humoris. Tak lama kemudian, akhirnya saya diizinkan menikah dengan suami yang bernama Usup. Namun pernikahan tidak menghambat saya untuk bekerja. Setelah menikah, saya dan suami masih tinggal bersama kedua orang tua saya karena suami belum punya modal untuk membuatkan rumah yang bisa kami tempati.

Saya meminta pendapat suami tentang keinginan saya membantu mencari tambahan uang untuk memenuhi kebutuhan rumah tangga kami. Ia mengizinkan saya untuk membuka usaha sendiri. Setelah uang yang saya hasilkan dari pekerjaan mendring ini terkumpul, saya lalu membuka sebuah warung sembako kecil di depan rumah. Namun mengelola usaha ini bukanlah hal yang mudah. Kendala yang saya hadapi pun bermacammacam. Sebagian orang dari luar desa mampir membeli dagangan saya. Namun kebanyakan pembelinya adalah tetangga dekat sehingga saya pun tak enak jika tidak memberi potongan harga. Bahkan jika ada yang nganjuk (berhutang) ke warung pasti saya berikan. Alhasil dagangan saya ludes dan saya kesulitan modal untuk kulakan lagi. Saya juga berjualan bensin eceran di samping warung ini. Dari jualan bensinlah sedikit demi sedikit saya bisa bangun lagi. Saya bisa belanja untuk mengisi warung lagi.

\subsection{Menjadi kader Posyandu}

Setelah menikah, saya mengikuti perkumpulan ibu-ibu Pembinaan Kesejahteraan Keluarga (PKK) di desa. Pertemuannya dilakukan setiap hari Kamis pukul 14.00 WIB. Dalam perkumpulan PKK ini saya dipercaya untuk memimpin pokja (kelompok kerja) 4 dan menjadi kader posyandu (pos pelayanan terpadu). Program-program PKK menjadikan saya seorang perempuan yang banyak tahu tentang bidang rumah tangga. Bersama para 
ibu lainnya, saya bisa bertukar pikiran dalam segala hal yang berhubungan dengan rumah tangga dan keluarga.

Menjadi ketua pokja 4 sangat menyenangkan. Saya bisa membuat berbagai kerajinan layaknya seseorang yang memiliki bakat dalam bidang keterampilan tangan, misalnya membuat aneka tas dan membuat karangan bunga serta hal-hal keputrian yang lainnya. Tidak diragukan lagi bagaimana lihainya saya dalam bidang masak-memasak. Selama menjadi anggota PKK, saya juga mendapat kepercayaan untuk menjadi seorang kader posyandu. Dalam program posyandu, saya mendapat tugas untuk mencatat berbagai masalah balita dan mengurus pemberian konsumsi atau makanan bergizi bagi ibu dan balitanya.

Setiap ada lomba PKK, saya sangat antusias mengikutinya karena banyak manfaat yang bisa saya dapatkan nanti. Lomba tingkat kabupaten yang pernah saya ikuti, membuat saya mengetahui banyak hal dan pengalaman. Setelah mengikuti lomba, saya belajar untuk mempraktikkan hasil yang saya dapatkan dari lomba itu ke rumah. Saya pun mendapat teman yang banyak dari kader-kader PKK dari berbagai daerah.

Selain perkumpulan PKK, saya pun mengikuti kegiatan arisan dan yasinan (membaca surat Yasin dari kitab suci Al Quran) setiap Senin di Pondok Pesantren Darurrahman yang berada tidak jauh dari rumah. Selain mendapat pahala karena yasinan, saya juga berkesempatan menjadi bendahara arisan ibu-ibu ini. Ketika menjadi bendahara, saya mendapat pengalaman dalam mengelola keuangan. Saya harus berhati-hati dalam menjaga uang yang dipercayakan kepada saya. Bahkan dari jabatan ini, saya mendapat uang fungsional yang lumayan yang bisa digunakan untuk jajan anak-anak.

Saya memang sangat senang jika ikut dalam organisasi karena bisa mendapatkan banyak pengalaman serta mengikuti perkembangan zaman yang semakin maju. Jika saya hanya berdiam diri di rumah, maka bagaimana dengan masa depan keluarga saya? 


\subsection{Dari pedagang beralih menjadi petani}

Berdagang memang menyenangkan, sebab berbelanja (kebutuhan dagang) adalah salah satu hobi saya. Namun banyaknya kendala dalam berdagang membuat saya berpikir untuk melakukan hal lain. Saya dan suami pun menerima salah satu usulan dari orang tua yaitu mencoba untuk bertani. Saya merasa akan menemukan gairah hidup yang lain dengan bertani. Bahkan menurut orang tua, hidup saya akan menjadi begitu nyaman.

Sebenarnya, apa pun pekerjaannya akan saya lakukan bersama suami tercinta. Untunglah, suami mengerti keadaan saya yang tidak bisa diam. Suami saya pun tidak pernah memaksa saya untuk selalu diam di rumah dan menjadi ibu rumah tangga yang bisanya hanya masak dan mengurusi anak-anak. Saya ingin sekali membantu suami mencari tambahan uang untuk masa depan anak-anak. Saya ingin mereka tidak seperti saya yang tidak melanjutkan sekolah ke jenjang yang lebih tinggi karena ketiadaan biaya. Saya sadar betul akan pentingnya pendidikan, sehingga anak-anak saya haruslah mengenyam pendidikan yang cukup.

Maka dari itulah, saya dan suami lalu mencoba menggarap sawah. Seperti yang orang tua saya lakukan saat itu, sawah seluas satu hektar saya garap dengan menanam padi. Benih padi sudah saya dapatkan dari bapak, saya hanya tinggal menanamnya. Saya dan suami sangat beruntung karena tanah sawah yang kami miliki sangat subur sehingga tidak ada kendala yang berat. Saat kami menggarap sawah, waktu yang saya gunakan untuk mengurus rumah menjadi berkurang karena setelah sholat subuh saya dan suami sudah berangkat ke sawah untuk mencabuti rumput yang menggangu di sawah dan menyiram tanaman. Sore harinya, saya tetap ke sawah karena garapan sawah ini kita lakukan berdua tidak dibantu orang lain, jadi kami harus bekerja keras.

Saat musim hujan, saya dan suami menanam padi di sawah. Sedangkan pada musim ketigo (kemarau) kami menanam terung dan cabai. Hasil panen sangat menentukan kelangsungan hidup kami, jika melimpah sebanding dengan apa yang kami kerjakan selama ini. Namun, kami juga merasa kesulitan untuk menggarap sawah yang luas itu berdua saja. Akhirnya kami 
putuskan untuk mempekerjakan orang yang bertugas merawat kesuburan tanah dan membersihkan gulma yang dapat mengganggu pertumbuhan padi di sawah.

Pengairan di sawah kami juga sangat terjaga. Saat pertama kali panen padi, hasilnya sangat bagus yaitu gemuk dan berisi. Total hasil panenan saat itu yaitu sejumlah 40 sak atau karung berukuran $60 \mathrm{~kg}$. Saat panen pertama ini, separuh hasilnya dijual dan uangnya digunakan untuk membeli sebuah sepeda motor bekas. Alhamdulillah, saya dan suami sekarang bisa naik motor. Kendaraan roda dua inilah yang akhirnya mengantar kami ke mana saja. Sisa padi yang tidak dijual saya gunakan untuk persediaan makan keluarga kecilku. Saat saya mengandung, suami agak kesulitan menggarap sawah karena tidak ada yang membantunya. Akhirnya, ia mengajak adiknya untuk menggarap sawah bersama dan hasilnya pun dibagi dua.

Saya rasa bertani memang sangat menguntungkan, sekarang sawahku bertambah luas dan hasil panen padinya pun lebih banyak. Saya yang dulu tinggal di rumah orang tua, sekarang bahkan bisa membeli rumah yang kami tempati. Sementara orang tua saya lebih memilih tinggal di rumah sederhana di belakang rumah kami. Mereka ingin agar saya bisa memanfaatkan rumah ini dengan baik, karena lokasi rumah ini dekat dengan jalan raya yang bisa membuka peluang usaha.

\subsection{Belajar mengamplas dan mengukir}

Banyak perempuan di desa saya yang berperan ganda, selain menjadi ibu rumah tangga juga ikut bekerja untuk menambah nafkah keluarga. Mereka adalah perempuan pekerja keras dan berprinsip untuk tidak menggantungkan diri pada suami. Biasanya pekerjaan kasar seperti menukang dan mengukir kayu adalah pekerjaan yang hanya dilakukan oleh laki-laki. Namun jika datang ke desa saya, maka tidak akan sulit untuk melihat para perempuan yang melakukan pekerjaan kasar tersebut. Pekerjaan yang sangat menguras tenaga dan membuat tangan lentik mereka menjadi kasar dan mengapal.

Saat saya menjalani kegiatan rumah tangga seperti menyapu, bersih-bersih rumah dan lain sebagainya, saya masih punya waktu luang untuk mengobrol 
dengan tetangga saya.

Bagi saya, mereka adalah perempuan-perempuan yang tangguh, bisa bekerja mengukir kayu berjam-jam lamanya. Saya yang hanya bisa menemani mereka mengobrol merasa rugi, mengapa saya tidak ikut belajar mengukir seperti mereka saja? Karena saya yakin pasti bisa. Awalnya, garapan yang mereka kerjakan saya gunakan untuk berlatih. Pada waktu itu, hambatan yang saya dapatkan tidak begitu rumit.

Awalnya saya merusakkan hasil ukiran teman-teman. Bahkan jumlahnya sampai puluhan. Padahal itu pesanan orang untuk mereka garap dan nilai upahnya lumayan untuk jajan. Namun karena

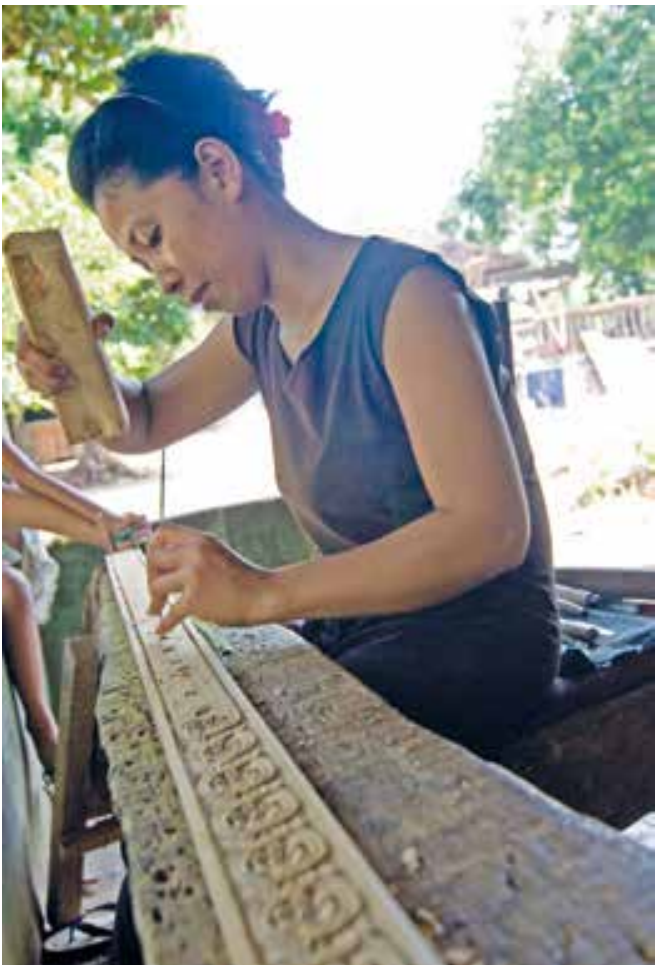

Gambar 1.2. Pekerjaan mengukir membutuhkan keahlian dan ketekunan hasil ukiran saya tidak karuan, maka saya pun harus mengganti kerugian teman-teman. Tak berapa lama berselang akhirnya saya mulai bisa mengukir dengan halus dan rapi. Kegiatan ini membuat kami semua senang, mengobrol sambil menghasilkan ukiran yang bagus.

Lama kelamaan, saya pun bosan dengan mengukir, sehingga saya mulai belajar mengamplas. Saya merasa mengamplas sangat mudah sehingga bisa saya taklukkan dengan sekejap mata. Namun saya tidak terlalu menyukai pekerjaan mengamplas karena debunya ke mana-mana sehingga seringkali mengalami batuk dan pilek. Saya sampai berpikir jika kelak saya bisa punya 
usaha mebel sendiri saya tak mau berurusan dengan mengamplas, namun akan lebih mengurus keuangannya atau menjadi managernya.

\subsection{Usaha mebel kecil-kecilan}

Setelah sukses bertani, kami sedikit banyak sudah mempunyai simpanan untuk modal untuk membuat brak kecil mebel. Mempunyai usaha mebel kecil-kecilan adalah cita-cita suami saya. Sayapun sebagai seorang istri akan mendukung keputusan suami tersebut. Sambil tetap menjalankan bertani, membuka warung sembako, dan sedikit menerima pesanan mendring, saya mulai berkenalan dengan banyak orang, terutama dengan pengusaha mebel dari beberapa desa yang dekat dengan desa saya. Saya banyak belajar tentang bagaimana memulai bisnis mebel di Jepara dari mereka.

Saat itu, suami sudah memiliki modal untuk memproduksi kayu menjadi barang jadi. Pada awalnya, sangat sulit memikirkan ke mana kami harus menjual barang produksi kami ini. Suami kemudian memutuskan untuk menjadi tukang kayu karena seperti layaknya pemuda Jepara lainnya, dia juga memiliki kemampuan mengukir dan menjadi tukang kayu. Selain suami, saya juga merekrut anak sendiri untuk membantu kami, serta anak muda dari desa yang memiliki kemampuan menjadi tukang kayu.

Saya sendiri yang memegang manajemen keuangan usaha baru kami. Saya juga berperan sebagai tenaga pemasaran untuk mencari pelanggan untuk barang yang kami produksi. Kendala awal yang kami hadapi adalah konsumen. Saya sempat kewalahan mencari pembeli barang yang sudah diproduksi ketika barang di rumah kami sangat menumpuk. Kemudian saya menawarkan barang produksi kami ke beberapa gudang di berbagai tempat di Jepara.

Tidak lama berselang, ada seorang laki-laki yang mencari barang jadi untuk toko mebelnya di Menganti. Dia menyambangi rumah kami dan menawar beberapa barang yang kami produksi. Setelah melihat-lihat, orang tersebut membeli beberapa barang produksi kami. Sepertinya dia puas dengan produksi kami dan menjadi pelanggan kami yang pertama. Kami pun 


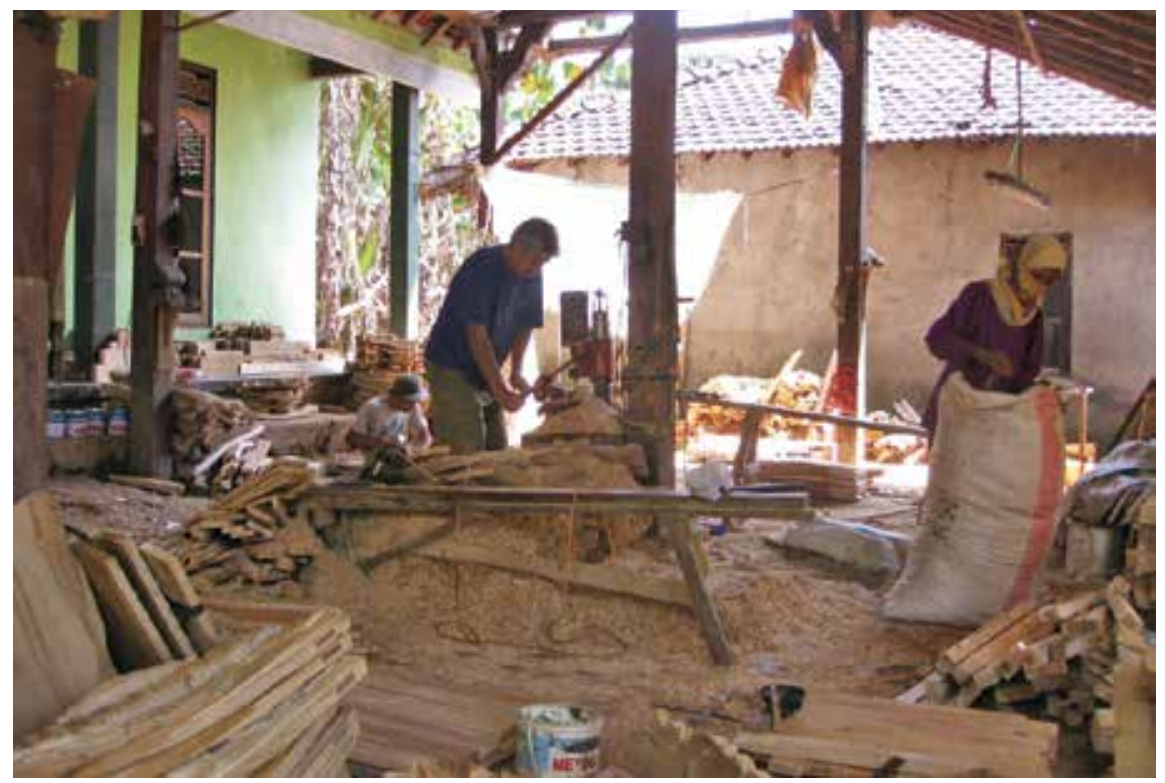

\section{Gambar 1.3. Suasana bengkel kerja di rumah saya}

menjalin kerja sama yang menguntungkan. Usaha produksi mebel kami berjalan bersama dengan sawah garapan serta usaha dagang.

Akhirnya banyak pelanggan yang silih-berganti datang ke gudang saya. Saya juga tak gentar kesana-kemari mencari konsumen baru. Kendala kami sekarang adalah jumlah karyawan yang kurang, padahal banyak pesanan yang mulai berdatangan. Saya pun mulai mencari karyawan baru. Karyawan kami sekarang bertambah menjadi 10 orang. Usaha mebel kami ini memproduksi kursi hongkong, pot, dan barang-barang lain yang mulai dipesan banyak pelanggan.

Kemajuan usaha mebel ini sangat saya perhatikan. Saya berusaha mempertahankan kualitas produksi agar tetap maksimal, agar semua pelanggan menjadi yakin dan puas akan hasil produksi kami. Saya juga suka memasarkan produksi usaha kami ke luar kota. Sampai akhirnya saya bertemu dengan teman lama yang mempunyai ruang pamer mebel di 
Surabaya. Saya pun diminta untuk mengirimkan barang-barang yang kami produksi ke Surabaya.

Setelah bisa menjual ke luar kota saya sangat bersyukur. Berarti usaha kami sudah mengalami kemajuan dan kepercayaan pelanggan makin bertambah. Perekonomian kami juga makin meningkat. Kehidupan keluarga sudah berkecukupan sehingga kebutuhan anak-anak bisa terpenuhi seluruhnya.

Kegiatan saya sehari-hari menjadi seperti ini: setiap pagi kami menggarap sawah, lalu siangnya suami bekerja mengukir kayu dan saya bekerja di toko sembako hingga sore hari. Setelah itu, keliling kampung menagih kredit yang menjadi tunggakan para tetangga.

Hari demi hari telah terlalui, kini anak kami sudah menginjak remaja. Saat SMP, anak kami yang pertama ingin sekali mempunyai kendaraan sendiri. Saya belikan dia sepeda, namun tidak pernah dipakainya. Ternyata banyak temannya yang naik sepeda motor sehingga dia pun menginginkan hal yang sama. Dia tidak mau menggunakan motor yang selama ini kami pakai untuk bekerja. Akhirnya kami berjanji padanya jika dia naik kelas dengan nilai bagus maka kami akan membelikannya sepeda motor seperti milik temantemannya. Anak kami senang sekali mendengarnya. Hal ini memacunya untuk bersemangat dalam mengejar nilai dan kami pun bersemangat dalam bekerja demi keinginan anak tercinta. Anak-anaklah yang menjadi motivasi untuk terus mengembangkan diri kami.

Sekarang semakin banyak teman dan mitra kerja saya di bidang mebel. Dari banyaknya teman dan kenalan saya ini akhirnya barang produksi kami bisa menjadi semakin maju karena pemasarannya semakin luas hingga ke luar Pulau Jawa. Pakanbaru adalah target usaha saya selanjutnya. Saya punya pesanan dari orang yang dikenalkan oleh teman. Pelanggan baru saya ini menjadi pelanggan tetap usaha saya. Jumlah produksi yang semakin bertambah karena pesanan yang tidak pernah sepi membuat saya kewalahan mencari karyawan lagi. Sekarang Alhamdulillah karyawan kami bertambah dan permintaan pasar bisa terpenuhi. Bahkan saya juga bisa memasarkan sampai ke Manado. 
Kiat-kiat sukses yang kami lakukan adalah (a) bekerja keras dan tidak mudah mengeluh dan (b) selalu berdoa agar diberi kesuksesan. Dengan adanya proyek CIFOR ini kami dapat banyak teman sehingga dapat berbagi pengalaman untuk memantapkan langkah-langkah kami menuju kesuksesan tersebut.

\subsection{Pendidikan anak-anak dan ibadah}

Anak saya yang pertama setelah lulus sekolah menengah atas tidak mau melanjutkan ke jenjang perkuliahan. Namun keinginan agar anak saya melanjutkan pendidikannya tidak berhenti. Meski tidak mau mendengarkan dan lebih suka bekerja dengan ayahnya dibandingkan memikirkan pelajaran di sekolah, dia lebih suka ikut bekerja sebagai karyawan perajin kayu untuk produksi mebel kami. Akhirnya, saya menghargai keputusannya. Dengan bantuan anak pertama, produksi barang tidak pernah berhenti karena dia sangat terampil mengukir serta bisa menjadikan kayu mentah menjadi barang yang berkualitas sehingga bisa dijual hingga ke luar Jawa.

Anak kami yang ke dua sekarang setelah lulus sekolah menengah pertama (SMP) dan melanjutkan ke pesantren di Surabaya. Saya berharap setelah dia tamat pesantren, saya ingin agar meneruskan pendidikannya ke jenjang yang lebih tinggi. Saya sangat berharap ia bisa mengejar cita-citanya dan menjadi orang yang sukses karena usahanya dan karena ilmunya yang tinggi, sementara saya hanya bisa mendukungnya dengan bantuan material untuk pendidikannya. Saya tetap bangga pada anak-anak dan tidak pernah menentang apa pun jalan yang mereka pilih. Saya hanya berusaha untuk mengawasi mereka agar tidak terjerumus ke jalan yang tidak baik.

Ketika kedua anak laki-lakiku beranjak dewasa dan mandiri, saya mulai berkonsentrasi ke pekerjaan lagi. Mebel memang usaha yang menjanjikan. Saya semakin dipercaya banyak pelanggan karena memberikan hasil produksi sesuai yang mereka pesan. Dengan berjalannya waktu, usaha yang saya tekuni dengan susah payah ini semakin berkembang. Semua ini saya jalani dengan berbagai hambatan yang terus saya lalui dan pelajari. 
Dalam kehidupan dunia ini, tentu tidaklah cukup dengan bekal harta saja. Kita pun juga harus memikirkan hidup kita di akherat kelak. Dengan bekal pendidikan agama yang saya dapatkan di lingkungan keluarga, saya pun mengisi hidup ini supaya seimbang dengan terus mengaji dan menjalankan ibadah dengan giat dan penuh ketekunan. Alhamdulillah saya dan suami mempunyai tabungan yang cukup untuk bisa mendaftar sebagai calon haji. Saya dan suami bertekad untuk menjalankan kewajiban kita sebagai manusia yang beriman untuk menjalankan ibadah haji. Namun di Jepara, antrian haji sangat panjang, jika mendaftar tahun ini berangkatnya bisa sampai lima tahun lagi. Saya dan suami harus sabar menunggu. Kami juga harus selalu bersyukur dengan nikmat yang diberikan oleh Allah kepada kami hingga saat ini.

\subsection{Mengenal kegiatan proyek FVC dan manfaatnya}

Setelah saya mengenal FVC lewat berbagai kegiatannya, saya kemudian menjadi anggota APKJ. Pandangan pertama kali tentang kegiatan FVC adalah jika terlibat dengan kegiatannya akan bermanfaat bagi peluang usaha yang saya jalani. Salah satunya adalah bisa menambah mitra kerja terutama setelah bergabung dengan APKJ. Jangkauan pemasaran pun semakin luas. Kegiatan yang dilakukan FVC di Jepara sangat menguntungkan bagi saya.

Manfaat utama yang saya dapatkan adalah informasi yang bermanfaat tentang cara agar barang yang kita buat bisa diterima oleh konsumen dan bisa menjadi produk yang berkualitas serta berdaya jual tinggi. Hal ini saya dapatkan dari berbagai kegiatan yang dilakukan FVC di Jepara, terutama dari pelatihan-pelatihan yang diadakan. Melalui berbagai pelatihan ini, saya juga mendapat relasi atau teman yang banyak untuk bisa saling berbagi informasi tentang pasar dan hal-hal lain yang berkaitan dengan usaha mebel sehingga saya bisa mengembangkan usaha yang saya jalani.

Pengaruh FVC bagi saya sangat banyak, dengan adanya kegiatan ini, perlahan-lahan usaha saya semakin berkembang dan stabil. Konsumen yang saya dapatkan pun semakin meningkat sehingga jumlah produksi kami semakin banyak. Hal ini karena saya selalu berusaha untuk menerapkankan apa pun yang saya dapatkan dari kegiatan di luar rumah ke dalam kehidupan 
sehari-hari. Sama halnya dengan kegiatan FVC yang banyak memberikan wawasan tentang dunia mebel. Saya berusaha menerapkan hasil pelatihan tersebut dalam usaha yang saya lakukan. Ternyata hal ini berpengaruh ke dalam hasil produksi dan kerja saya. Kualitas barang yang kami produksi meningkat dan kepercayaan pelanggan tetap terjaga. Hasilnya, penghasilan kami pun meningkat.

\subsection{Dampak kegiatan FVC yang dirasakan sekarang dan harapan ke depan}

Dari kegiatan FVC yang saya ikuti, ada beberapa dampak yang saya rasakan secara langsung, di antaranya yaitu:

- Penghasilan saya bertambah

Dengan mengikuti berbagai kegiatan pelatihan yang diadakan FVC, kemampuan saya untuk memproduksi mebel dengan kualitas yang baik juga meningkat. Hal berguna yang didapatkan dari pelatihan saya coba terapkan pada pekerjaan saya, sehingga produk yang kami buat menjadi lebih berkualitas dan membuat para pelanggan puas lalu kembali memesan kepada kami. Akhirnya, penghasilan yang saya dapatkan juga bertambah dengan banyaknya pelanggan yang datang kembali.

- Konsumen saya meningkat

Saya selalu mencoba untuk mempertahankan pelanggan dengan memberikan kualitas terbaik dari barang yang kami produksi. Saya pun selalu berusaha menjalin hubungan baik dengan teman dan kenalan yang saya temui di mana saja. Karena siapa tahu, dari kenalan tersebut akan mendapat pesanan dan menjadi pelanggan kami.

- Barang yang saya produksi semakin bervariasi dan berkualitas Adanya pelatihan tentang membuat produk mebel yang berkualitas dan tentang tren mebel yang sedang disukai, membuat saya semakin terpacu untuk berusaha membuat barang yang lebih beragam macamnya. Kualitas produk pun selalu diusahakan untuk tetap baik dan sesuai pesanan sehingga tidak akan mengecewakan pelanggan saya.

- Bisa bersosialisasi dengan berbagai macam pengusaha dan mendapat teman yang banyak dan saling bertukar informasi Dengan mengikuti kegiatan FVC, saya bisa bertemu banyak orang terutama para pengusaha dan perajin mebel di sekitar Jepara. 


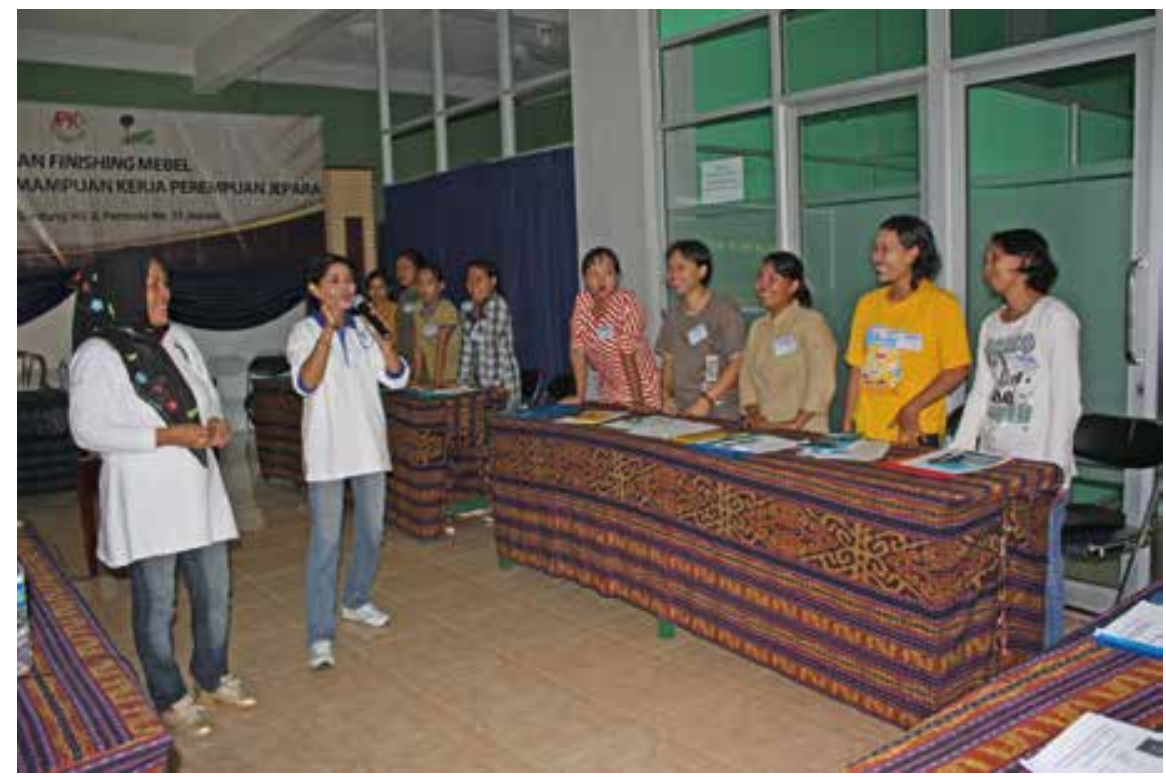

Gambar 1.4. Suasana pelatihan untuk perempuan yang diadakan oleh APKJ

Dari mereka, saya bisa bertukar infomasi mengenai hal-hal yang berhubungan dengan dunia mebel dan pasarnya. Selain itu, teman saya menjadi bertambah.

- Manajemen keuangan saya bisa terkendali dan terukur Salah satu pelatihan yang saya ikuti adalah tentang manajemen keuangan. Hal yang saya dapatkan ketika pelatihan saya coba terapkan dalam pengaturan keuangan saya sehari-hari, khususnya dalam manajemen usaha. Hasilnya, saya jadi bisa mengendalikan keuangan saya. Segala sesuatunya menjadi lebih terukur dan tidak ada yang terbuang percuma.

Harapan untuk masa depan tentunya adalah supaya usaha saya semakin berkembang, maju, dan selalu stabil meskipun banyak saingan. Hal-hal baik yang saya peroleh dari kegiatan-kegiatan yang saya ikuti tentunya diharapkan dapat membuat saya semakin kreatif dalam usaha mebel dan ukir. 
Mempertahankan hubungan baik dan selalu berusaha mencari pasar agar semakin banyak konsumen dan pesanan akan terus saya lakukan, sehingga usaha saya akan terus berjalan lancar dan tidak tertinggal dalam persaingan usaha.

Hal lain yang saya harapkan adalah bisa merambah ke pasar manca negara. Tentunya perlu persiapan dan peningkatan kemampuan yang harus saya miliki. Untuk itu, saya berharap agar bisa menambah pengetahuan tentang hal-hal ini. Saya juga berharap semoga kekeluargaan yang terjalin dengan adanya kegiatan FVC ini semakin terikat dengan baik dan bisa saling berbagi informasi dan saling bertukar pengalaman. 


\section{Bab 2.}

\section{Berdiri di antara pohon-pohon tumbang}

Oleh: Sulthon

\subsection{Masa sekolah}

Nama saya Sulthon, lahir di Desa Bugel RT 08 RW 03, yang sekarang berubah karena perubahan wilayah menjadi RT 16 RW 04 Kecamatan Kedung, Kabupaten Jepara. Di desa ini, saya diasuh oleh kedua orang tua saya dan sampai sekarang saya bertempat tinggal. Kedua orang tua saya adalah petani yang sehari-harinya hanya ke sawah. Namun bapak saya lebih banyak beraktivitas menjual es dawet, merantau ke Jawa Timur tepatnya di Kabupaten Sidoarjo.

Meski ekonomi keluarga kami tergolong pas-pasan atau boleh dibilang kurang mampu, orang tua kami selalu mengajarkan untuk menjadi seorang yang bisa berbagi dengan orang lain. Hal ini ditunjukkan dalam berbagai perilaku keseharian. Ibu saya selalu memberi contoh yang baik terhadap anak-anaknya. Di kala kami sedang memanen beberapa pohon yang berbuah seperti sawo, mangga, dan lain-lain, tak lupa ibuku membagikan kepada tetangga sekitar. Sempat terbersit dan terucapkan kepada ibu, "Bu, kenapa sih ibu selalu membagikan buah-buahan ini kepada tetangga kita, sementara anak-anak Ibu hanya kebagian sedikit-sedikit, sedangkan kalau mereka panen kita jarang dikasih?" sambil berekspresi jengkel kepada ibu. Ibu hanya bilang, "Sudahlah." Ibu saya juga seorang yang religius, rajin ke pondok dalam 
acara-acara pengajian. Setiap mau tidur, sempat saya mengungkapkan rasa jengkel saya karena ingin segera dikeloni, sementara ibu masih membaca doadoa sambil membawa tasbih. Beliau tidak hanya berkata namun berusaha berbuat untuk dapat dicontoh oleh anak-anaknya.

Saya adalah anak bungsu dari delapan bersaudara. Saya sekolah di Madrasah Ibtidaiyah Matholiul Huda Bugel setingkat SD yang ada di desa saya. Sejak TK, kelas satu sampai 5 SD, orang tua saya masih lengkap mendampingi saya walau dengan berbagai keterbatasan ekonomi. Namun di awal kelas 6 setelah saya dikhitankan, ibu terkena stroke dan meninggal seketika setelah beberapa saat dibawa ke rumah sakit namun tidak tertolong. Untunglah sejak kelas $3 \mathrm{SD}$, ibu meminta saya untuk belajar mengukir kepada tetangga teman bermain yang umurnya lebih tua dari saya. Waktu itu saya mengukir kursi gembel namanya, sebuah kursi yang terkenal dan banyak diproduksi di daerah saya kala itu. Saat itu saya tidak terlalu yakin kalau saya akan bisa, namun kenyataannya setelah ibu saya meninggal, saya sempat mengukir di tempat tetangga saya yang membuat mebel kursi gembel tersebut. Saya juga sudah mendapatkan bayaran atau upah pada waktu itu yang sudah membuat saya merasa percaya diri dan yakin bahwa saya bisa menghasilkan uang.

Sejak saat itu, seolah saya tidak percaya kalau ibu sudah tiada lagi di dunia ini. Kehidupan seperti tidak bisa lagi saya nikmati. Saya merindukan ketika tidur selalu ditemani ibu, setiap menangis ada yang memeluk dan meredam tangisan. Hari-hari sekolahku seolah tiada kegembiraan sampai akhirnya saya lulus dari kelas $6 \mathrm{MI} / \mathrm{SD}$. Saya kemudian diasuh oleh kakak tertua, selang tidak terlalu lama kemudian, ikut paman selama sekitar enam bulan. Di sana saya tidak bisa melanjutkan pendidikan formal setingkat SMP atau sederajat. Saya mencoba sekolah di Diniyah Mangun Sejati, 500 m dari tempat saya tinggal. Hingga suatu ketika, bapak pulang dari merantau dan menawari untuk ikut merantau ke Sidoarjo. Meski belum lulus kelas 1 Diniyah Wustho, saat itu saya keluar dan bilang kepada teman, Suradi, kalau saya akan berangkat ke Sidoarjo. Jika saya kembali dalam satu atau dua minggu, itu artinya saya akan melanjutkan sekolah di Diniyah ini, namun jika lebih dari itu berarti saya tidak melanjutkan. 
Berangkatlah saya merantau bersama bapak ke Sidoarjo untuk jualan es dawet. Pada tahun 1991 inilah saya mengawali hidup baru di daerah orangorang yang belum saya kenal, logat, dan gaya bahasanya pun terasa aneh di telinga saya. Selama beberapa hari di sana hidup terasa lebih berat. Setiap sore saya ikut membantu bapak menyiapkan adonan untuk pembuatan dawet serta pemanisnya dan pada malam harinya, sekitar jam 1 atau jam 2 dini hari, saya memarut kelapa untuk pembuatan santan sampai waktu subuh tiba. Sangat berat ternyata hidup di perantauan dengan seabreg aktivitasnya.

Selama beberapa hari di sana, tiba-tiba ada sebuah tawaran untuk bersekolah di sekolah yang baru tanpa membayar uang gedung. Kabar itu pun direspon oleh bapak dengan baik dan memberikan tawaran kepada saya untuk kembali bersekolah. Begitu saya ditawari, saya langsung setuju dan kebetulan hal itu yang sangat saya inginkan seperti anak-anak lain yang bersekolah pada masanya. Berbagai suka dan duka selama tiga tahun saya jalani, bangun jam 1 atau 2 pagi dini hari sampai setelah sholat subuh kemudian ke pasar, selesai membungkus es dawet kemudian pulang, mandi, kemudian sarapan sesaat, dan berangkat sekolah. Begitu aktivitas sehari-hari selama hidup di perantauan.

Ada banyak teman di sana, selain teman-teman sekitar tempat kost saya, juga teman-teman sesama perantauan dari Jombang yang punya usaha mebel kusen dan pintu rumah. Di sana saya banyak mengamati bagaimana seorang pemilik usaha dalam melayani kliennya, bagaimana menghitung, atau menentukan harga jualnya. Hari-hari di sana saya sudah terbiasa melihat aktivitas pembuatan mebel meski tidak sekompleks yang ada di Jepara.

Teman-teman sekolah saya juga banyak dan mereka sangat mencintai saya. Banyak guru yang suka dan prihatin terhadap saya yang merupakan anak Jepara satu-satunya di sekolahan itu. Mulai dari saya masuk ke sekolah itu di kelas satu sampai akhir sekolah pada kelas tiga MTs, saya selalu mendapatkan rangking 1 dari 21 siswa di kelas tersebut. Sesekali waktu teman-teman mengajak saya ke rumahnya untuk melihat aktivitas mereka membuat kerajinan blangkon. Beberapa dari mereka mengatakan bahwa uang saku saya adalah yang terbanyak sampai-sampai bisa menabung meski hanya dengan 
beberapa ribu rupiah saja. Hal ini karena teman-teman saya rata-rata berasal dari golongan ekonomi lemah atau biasa saja.

Tiba saatnya saya lulus MTs atau setingkat SMP pada tahun 1994, dan tak lama kemudian saya kembali ke Jepara untuk melanjutkan sekolah setingkat SMA. Sebenarnya saya tidak tega untuk meninggalkan bapak bekerja sendirian di sana, namun saya merasa hubungan dengan bapak kurang begitu harmonis karena beliau kurang memahami saya sebagai anak sekolah yang setiap saat harus masuk sekolah dan segera berangkat. Saat ada banyak pelanggan, beliau meminta untuk membantu sampai pelanggan terlayani semua sehingga saya sering terlambat sekolah. Begitu pula jika saya meminta uang untuk membayar SPP, beliau bilang, nanti dulu bungkus dawetnya yang banyak sampai pelanggan terlayani. Perasaan marah selalu ada padaku di saat-saat seperti ini.

Suatu ketika, saat terlambat datang ke sekolah, ada seorang siswa adik kelas yang terlambat masuk juga. Karena ia takut tidak boleh masuk kelas, akhirnya memarkir sepedanya cepat-cepat tanpa melihat posisinya sudah parkir dengan benar atau belum, langsung dia masuk kelas. Tiba-tiba sepeda anak tersebut roboh dan menimpa seluruh sepeda yang ada dengan jumlah lebih dari 40 sepeda yang ikut roboh. Karena yang terakhir berada di situ adalah saya, dikiranya saya yang merobohkan, dihukumlah saya untuk memarkirkan sepeda-sepeda tersebut dengan urutan parkir yang benar. Sungguh marah dan terpukul rasanya, namun saya hanyalah seorang murid yang tidak punya argumen lebih tinggi dari guru saya waktu itu sehingga saya hanya pasrah dan diam.

Selama merantau, saya sudah siapkan uang jajan untuk saya tabung dan sampai saya lulus uang itu mempunyai jumlah total sekitar Rp150.000,00 yang saya rencanakan untuk biaya pulang ke Jepara dan untuk masuk ke SMA. Tekad saya jika uang ini tidak cukup sampai saya lulus dan hanya bisa digunakan sampai kelas satu saja, maka saya akan pasrah dan yang penting saya sudah berusaha. Sesekali saya tinggal bersama kakak perempuan tertua saya, kadang juga saya tinggal dan ikut makan bersama kakak laki-laki saya. Setiap sekolah tidak pernah ada uang jajan, namun kadang-kadang ada teman saya yang baik dan mengajak saya untuk makan bersama. 
Sebelum saya lulus, saya sudah terbiasa dengan bekerja menjadi seorang tukang ukir saat liburan semester. Jumlah uang yang saya dapatkan memang belum besar, tapi cukup untuk beberapa kebutuhan, buat uang jajan sendiri atau untuk membantu membayar uang SPP. Sebelum saya lulus juga, tepatnya di kelas 2 Aliyah tahun 1996, bapak saya mengalami kecelakaan di tempat bekerja di Jawa Timur. Saat itu beliau selesai melaksanakan sholat subuh, berangkatlah dengan rombong atau tempat di mana segala keperluan es dawet dapat ditempatkan dan didorong atau dipindahkan. Sewaktu ditarik di posisi jalan yang menikung, dari arah barat ada kendaraan yang menabrak bapak saya beserta rombongnya. Sejak saat itulah bapak sudah tidak bisa bekerja lagi.

Selama sekolah, biaya sekolah saya lebih banyak tertolong dengan menjual hasil kebun peninggalan ibu saya yang ada di Desa Wanusobo, berupa pisang dan mangga yang kami jual setiap panennya. Namun saat menjelang ujian, saya dibantu oleh kakak termuda saya yang pada waktu itu sudah bekerja sebagai tukang ukir dan sudah menghasilkan. Tiba saatnya pengumuman kelulusan sekolah saya, saat itu adalah hari Kamis dan hari Jumatnya saya libur. Tanpa menunggu lama, langsung pada hari Sabtunya saya bekerja sebagai tukang ukir di Desa Menganti pada pertengahan tahun 1997. Saat itulah saya mengetahui rasanya pegang uang dengan hasil keringat sendiri. Hal yang sudah menjadi impian sekian lama untuk segera lepas dari jenjang pendidikan dan segera mengaplikasikan seluruh kemampuan di bidang kerja akhirnya tercapai.

\subsection{Masa peralihan profesi}

Pada pertengahan tahun 1997, saya bekerja sebagai tukang ukir subkontrak PT. Mitland Smith Indonesia sampai akhir tahun 2000, yang sampai sekarang perusahaannya masih solid namun lebih banyak beroperasi di Semarang. Padahal dulu banyak subkontraknya di Jepara. Setelah menjadi seorang ukir tersebut, banyak hal yang saya lakukan di antaranya adalah pernah bergabung dengan sebuah LSM lokal yang ada di Tegalsambi. Meski peran saya tidak terlalu penting di sana, banyak hal penting yang saya dapatkan di antaranya adalah bagaimana berinteraksi dengan berbagai hal dan juga kawan baru yang selama ini belum pernah saya temui. 


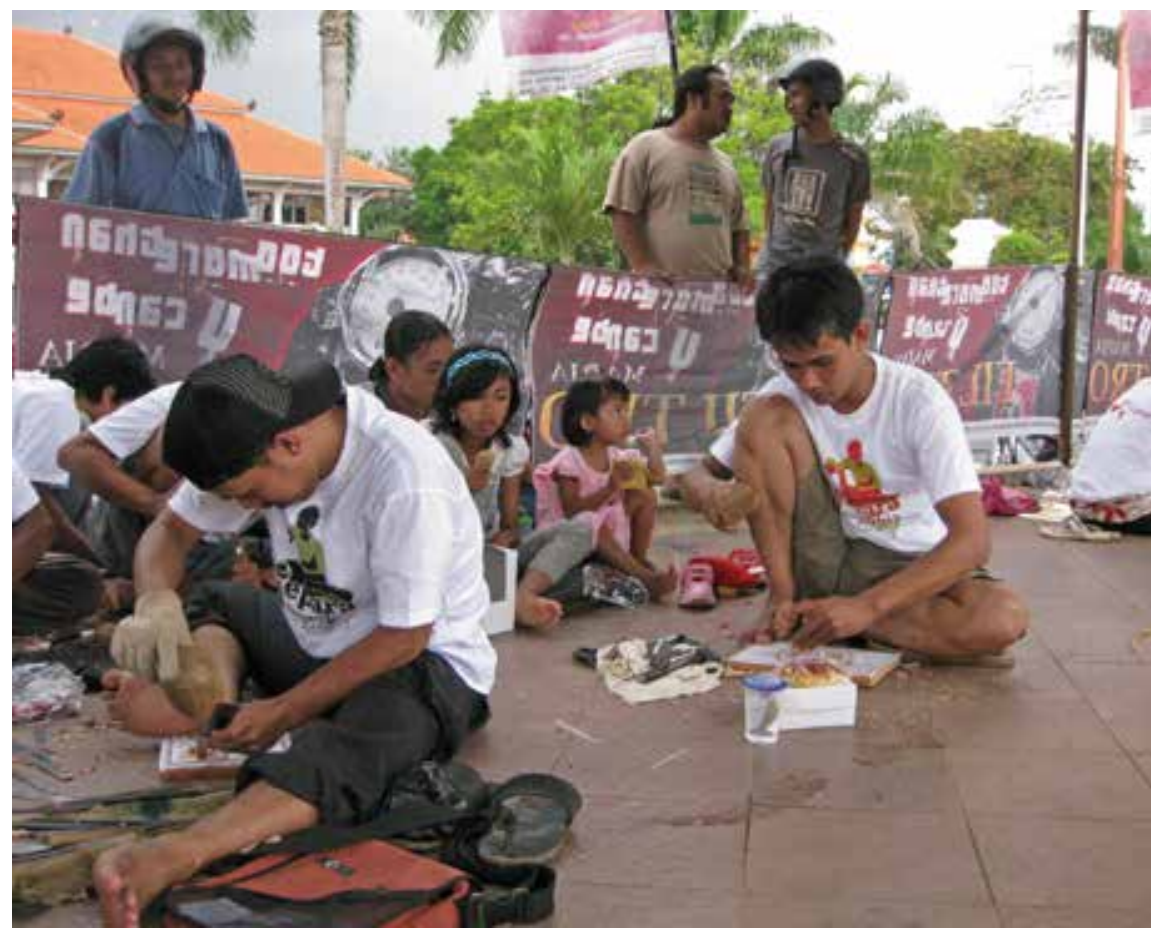

Gambar 2.1. Mengikuti lomba mengukir terbanyak versi MURI di Jepara

Pada masa itu juga saya diminta oleh Yayasan Maulana Mangun Sejati Desa Bugel yang dipimpin oleh K.H. Amin untuk mengelola sebuah koperasi. Di lembaga ini, saya menjabat sebagai juru buku selama 2 tahun. Berbagai pengalaman saya dapatkan berhadapan dengan bermacam karakteristik orang pada saat melakukan peminjaman di koperasi kami dengan berbagai macam alasan. Selama berkecimpung di koperasi ini, berbagai macam gaya orang untuk mendapatkan apa yang ia mau, ada yang berhasil kemudian lancar dalam mengangsur, namun banyak pula terjadi sebaliknya. Ada juga yang setelah mendapatkan pinjaman dari koperasi kami, mereka mengangsur hanya pada minggu pertama dan minggu ke dua atau ke tiga, namun pada minggu berikutnya mereka tidak melakukan angsuran dan akhirnya sulit untuk dihubungi, walhasil terjadi kredit macet. 
Pada tahun itu pula sempat selama 2 bulan saya kursus di Nissan Fortuna Jepara mengambil kursus bahasa Inggris. Tujuan saya kursus di sini bukan semata-mata untuk mendapatkan pelajaran dari tempat kursus tersebut namun juga untuk mencari banyak teman sebagai lawan bicara serta untuk menguji nyali saya dalam hal percakapan bahasa Inggris yang selama ini saya pelajari dari sekolah maupun dari banyak buku-buku referensi yang saya baca.

Usai kursus selama 2 bulan, saya mencoba untuk menguji nyali sekaligus mengembangkan keterampilan bahasa Inggris saya lebih matang dengan cara saya memberikan kursus kepada teman atau siapa pun yang bersedia. Pernah saya memberikan kursus di dua tempat di Desa Dongos, satu tempat di Desa Jondang, dan di Desa Menganti. Pernah pula saya mengajar untuk para bapak yang sedang belajar di Paket C setingkat dengan SMA di Bugel serta mengajar di Diniyah Islamiyah Mangun Sejati Bugel. Tidak semua aktivitas saya ini menghasilkan secara finansial, namun saya lebih fokus pada bagaimana ilmu saya bisa bermanfaat buat orang lain. Selain itu juga untuk meningkatkankemam puan saya pada saat muncul kesulitan-kesulitan ketika mengajar.

Pada pertengahan 1999, sudah selama satu tahun saya mengajar bahasa Inggris di Jondang, tak jauh dari desa saya. Orang-orang yang saya ajar kala itu adalah dari kalangan siswa sekolah SMP dan SMA, juga para pekerja yang mau bergabung mengembangkan kemampuannya dalam bahasa Inggris.

Pada masa ini juga saya mencoba berbagai kegiatan Multi Level Marketing (MLM) dan semuanya belum pernah berhasil secara gemilang. Meski demikian, saya menyukai gaya dan semangat orang-orang yang ada di bisnis ini. Inti yang saya dapatkan dari kegiatan bisnis MLM ini adalah bagaimana memotivasi diri sendiri dengan cara memberi motivasi kepada orang lain. Kegiatan yang kelihatannya hanya sebatas kumpul-kumpul kemudian menjual produk-produk MLM ini selintas banyak buang-buang energi, namun dari banyak bertemu orang-orang baru dengan latar belakang pendidikan serta profesi yang berbeda inilah, saya banyak menimba ilmu dan pengalaman yang tidak tertulis. 
Sampai pada akhir tahun 2000, saya beraktivitas sebagai tukang ukir dengan berbagai macam aktivitas sampingan yang lain dan akhirnya mendapatkan sebuah pemikiran untuk berganti profesi lain. Hal yang mendasari saya untuk beralih profesi adalah karena bekerja sebagai tukang ukir butuh tenaga besar namun hasilnya tidak begitu besar. Saya membayangkan bagaimana kalau saya tua nanti, apakah memungkinkan saya masih menjadi tukang ukir, sementara itu saya masih punya keinginan untuk melanjutkan kuliah saya? Lalu apakah nanti saya mampu menyekolahkan anak-anak saya ke jenjang yang yang lebih tinggi?

Pertanyaan-pertanyaan itu terus bergejolak dalam benak saya. Suatu ketika ada sebuah tawaran dari teman saya, Ahmad Zainuddin kalau ada sebuah pemilik ruang pameran di Desa Rengging, Kecamatan Pecangaan yang membutuhkan karyawan sebagai shopkeeper pelayan toko ini. Tanpa basabasi saya terima tawaran itu meski gaji yang ditawarkan tidaklah sesuai yang saya harapkan. Gaji Rp 250 ribu per bulan sangat jauh dari hasil yang saya terima pada saat saya mengukir yang rata-rata di atas $\mathrm{Rp} 750 \mathrm{ribu}$ tiap bulannya.

Alasan saya untuk menerima pekerjaan ini adalah saya ingin mengetahui lebih banyak tentang mebel, mendapatkan pengalaman-pengalaman bagaimana menghadapi klien, melatih ketrampilan saya berbahasa Inggris, dan hal-hal penting lain yang berkaitan. Ternyata dalam perjalanannya saya tidak hanya sebagai pelayan toko saja tetapi juga diminta oleh sang juragan untuk menggambar produk dari beberapa pesanan. Dengan kemampuan terbatas karena tidak mempunyai latar belakang menggambar, saya kerjakan tugas tersebut yang akhirnya lama-kelamaan justru para tukang di situ menanyakan hal-hal berkaitan dengan produk yang digarap kepada saya sebagai tukang gambarnya. Pengalaman ini justru yang akhirnya menginspirasi saya untuk kuliah di bidang desain.

Lima bulan berjalan sudah saya bekerja di ruang pameran ini dengan pekerjaan sedikit lebih banyak dari kesepakatan semula, belum ada kenaikan gaji sebagaimana yang dijanjikan oleh bos saya yang waktu itu dalam perjanjian awal disebutkan akan dinaikkan setelah lima bulan. Saat 
itulah saya mengajukan untuk bekerja paruh waktu dengan alasan mau melanjutkan kuliah saya. Namun beliau menjawab tidak bisa karena sulit untuk menggajinya meski dengan perincian Rp 250 ribu dikurangi paruh waktu yang bisa saja mulai kerja dari jam 2 siang atau lebih. Akhirnya saya putuskan untuk keluar dan mencari pekerjaan di tempat lain pada akhir bulan Juli 2001.

Sebelum akhir masa kerja saya di tempat itu, saya bertemu dengan seorang pembeli dari Australia yang akhirnya menawari saya bekerja di perusahaannya. Sore itu, pembeli tersebut memesan beberapa produk di tempat bos saya. Sebelum ia pulang, ternyata bos saya sudah pulang lebih awal sehingga saya harus pulang agak larut. Setelah transaksi kami selesai, saya bertanya kepadanya dengan pertanyaan, "apakah mister pulang ke arah kiri atau ke kanan?” menggunakan bahasa Inggris. Kemudian dia menjawab, "Kenapa?" Kemudian saya menerangkan kalau saya tidak punya kendaraan untuk pulang dan tidak ada transportasi umum ke arah rumah saya. Kemudian orang asing itu bertanya lagi "Ke rumahmu ada berapa kali belokan?" Saya bilang "Tiga kali." Lalu dia menjawab "OK, saya antar kamu pulang." Dengan perasaan sangat gembira saya ucapkan terima kasih kepadanya.

Dalam perjalanan pulang, saya bercerita banyak termasuk tentang niat saya untuk keluar dari perusahaan tempat saya sedang bekerja. Kemudian dia juga menanyakan kenapa saya ingin keluar. Akhirnya saya jelaskan kalau saya ingin melanjutkan kuliah namun bos menolak saya untuk bekerja paruh waktu. Sampai pada akhirnya dia menawarkan untuk bekerja di bengkel kerjanya. Sempat saya lontarkan kepadanya apakah saya bisa bekerja sementara saya tidak punya keahlian yang sesuai. Dia bilang kalau saya bisa menggambar lebih baik daripada dia.

Sesampainya di rumah, kami mengobrol sebentar hingga akhirnya dia memberi saya alamat email untuk mengabari kapan saya siap untuk bekerja. Sesegera mungkin saya mengirim email dan menyatakan siap untuk bekerja. Tepatnya pada tanggal 1 Agustus 2001, saya bekerja di tempat orang Australia tersebut. Namun tak lama saya bekerja di sana, tepatnya 
tanggal 21 Agustus 2001, ayah saya meninggal dunia karena penyakit komplikasi yang sudah bertahun-tahun dideritanya. Bos saya inipun dengan belasungkawa yang mendalam ikut melayat atas kematian ayah saya. Hal ini yang membuat saya sangat hormat kepadanya, meskipun dia orang asing rasa kemanusiaannya tetap seperti orang-orang kita sendiri. Meski saya belum mendapatkan gaji saya yang pertama, saya sudah menganggap ini sebagai awal kesuksesan. Saya membayangkan andai kata bapak dan ibu saya masih ada dan saya bisa bekerja dengan orang asing dengan gaji yang lumayan, betapa bangganya mereka. Saya akan berikan gaji pertama saya untuk membahagiakan mereka, namun itu tidak mungkin karena mereka telah tiada. Hanya doa-doa dan perbuatan baik yang diajarkan serta yang bisa saya amalkan yang dapat membuat mereka bahagia di alam kuburnya.

Pada bulan Agustus itu juga saya akhirnya bisa melanjutkan kuliah saya di ATIKA atau yang sekarang berubah namanya menjadi STTDNU-Jepara (Sekolah Tinggi Teknologi dan Desain Nahdlatul Ulama). Kuliah ini memadukan aktivitas dalam bekerja yang sehari-harinya menggambar dan kontrol kualitas dengan apa yang sedang saya pelajari di kampus. Meski kuliah saya hanya 1 semester dan akhirnya saya cuti untuk beberapa saat karena pada semester 2 saya menikah dengan gadis pujaan saya. Di sekolah ini saya mampu mendesain, menggambar, dan memadukan produk satu dengan produk yang lain yang akhirnya kemampuan ini dapat memperkuat posisi saya sebagai drafter dan pengontrol kualitas.

\subsection{Pengalaman bekerja di bidang mebel dengan orang asing}

Belum satu tahun bekerja sama dengan orang Australia yang punya pasar di Singapura bersama partner perempuannya, akhirnya mereka berpisah karena sesuatu hal. Kemudian saya berada di antara dua pilihan, memilih orang yang memberikan jalan perubahan dan kemajuan kepada saya atau memilih bekerja dengan partner perempuannya yang sebenarnya tidak terlalu dekat dengan saya. Partner perempuannya adalah warga negara Filipina, namun lama tinggal di Singapura. Saya akhirnya memilih untuk bekerja dengan perempuan itu karena saya merasa pada waktu itu bos yang dari Australia sudah banyak tahu tentang mebel dan konstruksinya, sedangkan 
yang perempuan belum tahu banyak tentang hal itu. Saya berpikir kalau saya pilih yang laki-laki maka dia akan jaya dan yang perempuannya akan mati bisnisnya, tapi kalau saya pilih yang perempuan nantinya akan sama-sama jalan dan besar bersama.

Banyak pengalaman yang saya dapatkan selama bekerja dengan bos saya dari Filipina ini, baik pengalaman pahit ataupun yang manis. Dia adalah orang yang sangat dermawan, sehingga pada akhirnya saya menganggap dia seperti kakak saya sendiri, begitu pula dia menganggap saya bukan sebagai karyawan tapi sebagai seorang adik. Kadang-kadang saya merasa jengkel karena sesuatu hal kemudian kami bertengkar, namun tak selang beberapa menit baikan lagi, begitu selalu.

Selama saya jadi anak buahnya, banyak hal yang saya dapatkan termasuk bagaimana menjaga konsistensi kualitas produk. Ada memang saat-saat dia marah ketika mendapatkan produk yang tidak berkualitas karena pecah atau karena kualitas kayunya yang buruk sehingga dia marah dengan mengucapkan "bodoh" dan sejenisnya kepada saya. Selain itu juga peristiwaperistiwa lain ketika dia mengucapkan kalimat-kalimat yang pada waktu itu saya sangat tidak menyukainya. Hal yang paling membuat saya malu adalah ketika dia dan teman-teman sesama perempuan dari Indonesia datang bersama di tempat pemasok, dan di saat itu pula ada keluhan dari dia karena ada beberapa kayu yang tidak sesuai dengan pesanan. Secara spontan dia mengucapkan kata-kata bodoh kepada saya di hadapan teman-teman perempuannya itu. Dalam hati saya sangatlah marah, namun apa boleh dikata, karena saya butuh pekerjaan ini dan jika saya bandingkan dengan bekerja di tempat lain sungguh tidak menantang keilmuan saya serta gajinya yang tidak seberapa.

Dari pengalaman-pengalaman selama bekerja dengan orang asing tersebut saya mencoba hal-hal baik yang bisa saya terapkan dalam kehidupan bisnis sehari-hari sampai sekarang. Termasuk sikap tegas terhadap para pemasok sesuai apa yang sudah menjadi kesepakatan transaksi awal, kemudian jika mereka tidak dapat menyediakan barang sesuai pesanan maka harus diambil 
tindakan tegas sebagai konsekuensinya, mereparasi jika memungkinkan, atau menolak barang yang telah diproduksi.

Hal tersebut yang kami lakukan dalam menjalankan bisnis mebel selama ini sambil sesekali waktu memberikan pemahaman terhadap para perajin betapa pentingnya menaati persetujuan awal pemesanan barang.

Pada tahun 2005, saya diminta oleh bos untuk ke Singapura, tempat dia tinggal dan menjalankan bisnisnya. Perjalanan ini sebagai awal saya menginjakkan kaki di negeri orang. Saya ditemani oleh salah seorang karyawan atau tukang kayu dari perajin mebel kayu jati tua yang ada di Bangsri. Tujuan kami diundang ke sana adalah untuk mereparasi beberapa barang yang rusak, baik karena pecah, lecet, atau karena finishingnya yang mengelupas. Kami pergi dengan perasaan was-was campur takut karena belum punya banyak pengalaman di sana untuk melaksanakan tugas-tugas yang diberikan oleh sang bos.

Setibanya di Bandara Changi Singapura, saya sedikit digojlog oleh pihak imigrasi yang berwajah India, super lebat kumis dan jenggotnya. Dia memberikan pertanyaan kepada saya apakah saya ke Singapura untuk bekerja atau untuk kunjungan saja. Saat itu saya menjawab hanya untuk kunjungan dan lihat pameran mebel saja. Namun seolah dia tidak percaya sehingga dia minta nama dan nomer telpon sang bos. Izin yang saya minta untuk tinggal 1 bulan di sana ditolak dengan hanya diberi izin 1 minggu saja. Maklum, karena passport saya masih baru dan bersih sehingga sangat mudah untuk dipersulit oleh pihak imigrasi.

Setelah berbagai pertanyaan bisa saya jawab, berhasillah saya masuk dan tak lama kemudian bos saya sudah menunggu di balik kaca pintu masuk kantor imigrasi. Dipeluk dan diciumlah saya layaknya seorang adik yang lama tidak bertemu. Satu bulan saya di sana bekerja dan berperan membantu sebagai pelayan toko, dan kadang-kadang sebagai tukang reparasi mebel, mengerjakan finishing, dan juga melakukan delivery kepada customer dengan banyak hal yang bisa saya pelajari. Terutama ketika melakukan delivery 
kepada customer sementara ada masalah dengan produk yang dipesannya, sungguh membingungkan. Hal yang paling menakutkan buat saya adalah ketika hidup di negeri orang kemudian ketahuan tanpa permit kerja, namun kenyataannya saya bekerja di sana. Tidak bisa saya bayangkan hukuman apa yang akan saya terima. Alhamdulillah, selama saya di sana tidak terjadi halhal yang tidak diinginkan.

Sampai akhirnya pada tahun 2007, tepatnya di bulan Februari bersamaan dengan pameran produk mebel international yang ada di Changi, saya diminta lagi datang ke Singapura untuk melakukan hal yang sama seperti pada tahun 2005. Namun kedatangan saya saat ini sendirian tanpa membawa teman dari Jepara. Perasaan percaya diri saya sudah lumayan tinggi sehingga mantap di setiap langkah. Pernah suatu ketika di tahun tersebut juga melakukan reparasi sebuah sofa set di sebuah cafe 'BALIBA' di sebuah Kota Orchard namanya. Sofa tersebut hasil dari desain saya dengan nama boomerang sofa yang kakinya lebih tinggi dari normalnya karena bantalan yang dipilih tebalnya lebih dari yang seharusnya. Saya sewa seorang pekerja India untuk menemani saya angkat bongkar barang dan akhirnya selesai selama dua jam dengan hasil yang memuaskan.

\subsection{Melangkah dalam dunia baru menjadi seorang pengusaha-perajin mebel}

Menjadi seorang pengusaha mebel bukanlah cita-cita saya karena yang saya tahu menjadi seorang mebelair identik dengan sebuah kegiatan yang rumit dan memusingkan. Hal ini terlintas dalam benak saya karena saya dekat dengan area permebelan yang pada saatnya orang sering marahmarah saat ada sebuah pekerjaan yang tidak sesuai yang diharapkan. Sebagai contoh, ketika ada karyawan yang tidak masuk kerja pada saat yang sangat dibutuhkan untuk menyelesaikan sebuah pesanan, atau terjadinya kesalahan konstruksi yang mengakibatkan sebuah produk tidak kuat atau kedalaman ukiran yang mengakibatkan tidak elok dipandang dan lain sebagainya.

Terlebih jika berurusan dengan keuangan, misalnya pekerja mengharapkan gaji atau bayaran mereka di hari Kamis. Namun di hari-hari lain para pekerja 
tersebut membutuhkan uang untuk hal-hal yang bersifat mendesak dan pengusaha mebel tidak memiliki uang. Tentu saja kondisi ini memusingkan.

Selintas melihat dari kesuksesan dari seseorang terbayang dengan sebuah kesibukan dalam melakukan banyak hal, seperti bertemu dengan klien, travelling, mempunyai kendaraan yang bagus, melakukan sesuatu yang disukai dengan fasilitas yang mendukung seperti pergi haji, berekreasi, mendatangi keluarga jauh dengan mudah. Itu adalah sebagian dari citacita saya, tapi belum tahu dalam hal apa bisnis yang akan digeluti dan yang terlintas hanyalah kesibukan dan kesuksesan.

Waktu itu saya sudah menikah dan mempunyai dua orang anak di mana tanggung jawab sebagai kepala rumah tangga sudah semakin banyak tuntutannya baik secara material maupun spiritual. Berusaha sekeras mungkin untuk mencapai sebuah impian kesuksesan mutlak dilakukan. Karena kami lahir bukan dari keluarga yang membagikan banyak harta, semangat perjuangan hidup saja yang diwariskan untuk dapat kami teruskan.

Saat itu mebel merupakan satu-satunya bisnis yang mempunyai prospek bagi saya, di samping sudah lama saya geluti dan saya pelajari sehingga hal ini menjadi pilihan satu-satunya pada waktu itu. Lonjakan bisnis di Jepara ini yang dimulai dari adanya krisis moneter Indonesia tahun 1998 sampai dengan sekitar 2005, bisnis mebel yang dimiliki oleh bos saya terlihat baikbaik saja bahkan sempat pada akhir 2005, saya diundang ke Singapura untuk melihat dan merasakan langsung bagaimana proses penjualan yang ada di negara tersebut. Saat saya datang tahun itu, para pengunjung memang ramai dan menghasilkan banyak transaksi penjualan. Namun hal ini berubah ketika saya datang kembali tahun 2007, kondisi bisnis tidak terlalu sibuk. Hingga satu bulan lamanya saya di sana, penjualan tidak mencapai angka minimal yang diharapkan.

Tahun 2008 awal, kondisi permebelan semakin parah dengan adanya krisis ekonomi dunia. Tepatnya pada bulan Maret 2008, kami sesama pekerja terakhir berkumpul bersama untuk pergi ke Singapura tersebut. Sejak saat itu, saya sudah tidak lagi menerima gaji tiap bulannya dan saat itu juga saya 
mengubah pola pikir saya bagaimana menjadi seorang pengusaha. Selama ini saya bergantung pada gaji, tidak pernah terbersit jika suatu ketika bisnis yang saya geluti dan bergantung pada orang lain itu, tiba saat surutnya.

Kehidupan yang saya jalani pada bulan-bulan di tahun 2008 ini tidak seperti biasanya, banyak keinginan saya yang tertunda karena faktor finansial yang tidak mendukung. Kehidupan lebih prihatin serta membelanjakan keuangan dengan sangat hati-hati. Berbagai cara saya untuk mendapatkan klien yang membutuhkan jasa saya sebagai seorang perajin, namun tidak banyak yang saya dapatkan sesuai harapan karena kondisi pada saat itu. Saya lebih banyak berkonsentrasi pada pembuatan mebel berbahan kayu jati recycle. Sesekali dapat beberapa custom order dan sesekali surut. Belum tentu dalam dua minggu mendapatkan klien yang memberi pekerjaan.

\subsection{Pengalaman masa transisi 2008 dan pertemuan dengan proyek FVC CIFOR}

Selama hampir 7 tahun sejak pertengahan tahun 2001 sampai dengan awal 2008, saya menikmati pekerjaan sebagai representasi sang bos, dan selama itu pula saya menimba banyak ilmu dan pengalaman berinteraksi dalam dunia bisnis permebelan. Dalam hal-hal yang berkaitan dengan finansial hampir secara keseluruhan mencukupi kebutuhan kami sekeluarga. Jarang sekali kami mempunyai permasalahan yang ada kaitannya dengan keuangan. Kami merasa bahwa bisnis ini akan terus berlangsung tanpa mengalami gejolak yang berarti.

Pada tahun 2008 tepatnya bulan Maret, kehidupan bisnis partner saya mulai bergejolak seiring dengan adanya krisis ekonomi dunia. Hal ini menyebabkan bisnis mebel yang sudah kami geluti sekian lama tidak dapat bertahan. Harga jual di pasar Singapura semakin merosot, persaingan yang semakin tidak bisa dikendalikan serta bahan baku dan bahan pendukung dalam negeri yang terus menerus mengalami kenaikan yang tentu saja ini berpengaruh erat bagi kehidupan saya yang saat itu menggantungkan diri pada satu-satunya bisnis yang saya geluti. 
Berbulan-bulan kehidupan saya dan keluarga dalam keprihatinan karena sebelumnya kami hidup hanya dengan gaji tiap bulannya. Tidak ada sumber pendapatan lain dan selama tahun itu pula hasil yang kami dapatkan digunakan untuk memulai membangun rumah dan membiayai kuliah saya di ATIKA-STTDNU Jepara. Tidak ada pula yang kami tabung untuk rencana bisnis ke depan. Banyak sekali lamaran yang saya ajukan diterima oleh perusahaan, namun tak satupun perusahaan yang menggaji tinggi sesuai dengan harapan saya. Gaji yang ditawarkan hanya berkisar dari Rp 900 ribu sampai dengan satu juta rupiah saja, sampai akhirnya saya hanya menunggu saat-saat saya bisa meraih angka sesuai harapan. Hari demi hari, minggu demi minggu, dan bulan demi bulan saya lewati hanyalah berisi pengeluaranpengeluaran tanpa adanya pendapatan untuk keluarga saya.

Melihat keadaan keluarga saya, semakin terpuruk dan teriris rasanya hati saya. Apalagi ketika lahir anak saya yang ke dua pada awal Januari 2008, gaji yang saya diterima tidak pada waktunya. Terkadang telat sampai 2 minggu karena suasana penjualan yang ada di Singapura sepi bahkan yang ada kondisi minus untuk menutupi segala biaya operasional perusahaan.

Dengan penuh semangat untuk mengentaskan kehidupan keluarga dari kekurangan secara ekonomi, di awal tahun 2007 saya bekerja sebagai drafter di sebuah perusahaan mebel PT. Michael Scott di desa Menganti. Gaji bulanan yang saya terima kala itu sebesar satu juta limaratus ribu rupiah. Bersamaan ini pula saya juga diminta oleh pihak kampus tempat saya kuliah untuk menjadi dosen grafis. Tawaran itupun saya terima sebagai pengisi waktu-waktu kosong saya yaitu pada hari Sabtu sore dan Minggu pagi sampai malam hari selama satu tahun. Hari-hari seperti ini saya lewati dengan penuh harapan untuk mendapatkan kesempatan yang lebih baik, mendapatkan penghasilan yang lebih dari apa yang saya dapatkan pada saat itu. Namun belum lama bekerja di perusahaan itu, datanglah tawaran dari sesama teman saya di bidang kayu lawas dan menawari pekerjaan sebagai pelayan toko di sebuah perusahaan mebel antik yang ada di Lebuawu Jepara dengan gaji yang sama sebagaimana seorang drafter. 
Kemudian saya berpindah kerja ke tempat mebel antik tersebut. Selama bekerja di tempat mebel antik ini, banyak ilmu dan referensi yang saya pelajari, di antaranya adalah bagaimana old wood atau recycle ini tidak hanya bergantung kepada kayu jati tua saja. Produk yang dijual di perusahaan antik ini dari yang murni old antique teak, ada yang campuran, dan bahkan ada yang bukan jati. Koleksi yang begitu banyak dengan berbagai material kayu membuat pikiran saya lebih terbuka bahwa siapa saja bisa menjual produk mebelnya dengan harga yang mempunyai margin tinggi, bergantung dari desain dan bagaimana cara memasarkannya.

Hanya sekitar empat bulan saja bekerja di perusahaan ini dengan penjualan yang tidak terlalu banyak karena memang pada musim sepi pesanan akhirnya dengan berat hati saya mengundurkan diri. Dengan perasaat takut saya menyampaikan pengunduran diri saya kepada pemilik dengan alasan bahwa saat itu kondisi penjualan sedang sangat sepi, saya khawatir pemilik akan buang-buang uang saja untuk menggaji saya. Dengan ekspresi penuh persahabatan sang pemilik pun memberikan izin atas pengunduran diri saya.

Usai bekerja di perusahaan antik itu tepatnya pada pertengahan 2007, kami mencoba bisnis jualan sembako, dengan menyewa sebuah toko kecil di tetangga desa kami. Kami tahu bahwa sangat berat untuk bersaing dalam bisnis tersebut karena di daerah sekitar banyak sekali toko-toko penjual sembako. Namun saat itu kami optimis karena kami dapat menjual beras khususnya sedikit lebih murah karena ibu mertua mempunyai bisnis jual beras dengan kapasitas yang lebih besar dan pembelian dari penanam padi secara langsung. Namun kenyataannya, kehidupan kami tidak semakin membaik, tambah bulan hutang kami menjadi semakin bertambah sampai dengan akhir bulan September 2008.

Sampai suatu ketika pada bulan Oktober tahun itu, saya ditawari pekerjaan oleh dua orang teman saya, sesama tukang ukir yang pada waktu itu sedang bekerja di sebuah perusahaan mebel di Semarang. Dia menawarkan pekerjaan menjadi seorang supervisi di sebuah perusahaan milik orang asing dari Timur Tengah. Teman saya yang satunya adalah ketika sama-sama kuliah UT (Universitas Terbuka-Semarang) tahun 1999 yang menawari untuk menjadi 
pemandu seorang peneliti. Saat itu saya belum tahu jika peneliti tersebut ada kaitannya dengan CIFOR dan FVC, bahkan saya juga belum tahu apa itu CIFOR dan proyeknya.

Sore kala saya mendapatkan dua tawaran itu, rasanya sulit untuk menentukan yang mana. Satu sisi, saya ingin ada pekerjaan yang tidak hanya sementara, sehingga waktu itu saya lebih memilih tawaran dari Semarang karena saya berpikir bekerja dengan orang asing dengan posisi yang lumayan dengan harapan saya akan mendapatkan angka sesuai dengan posisi yang ditawarkan. Pada malam harinya, saya sakit perut dan saya coba minum obat, namun badan saya malah menjadi panas. Saya tunggu sampai jam 8 malam, masih juga panas akhirnya saya pergi ke dokter terdekat.

Sampai di rumah saya minum obat tersebut, meski biasanya dalam beberapa menit badan saya berkeringat dan berangsur sembuh, namun tidak kali ini, justru badan saya semakin panas sampai jam 11 malam. Dengan tekad yang kuat keinginan saya untuk sembuh karena pada pagi harinya saya harus pergi ke Semarang untuk wawancara ke perusahaan asing tersebut. Akhirnya, tanpa resep dari siapa pun saya minum air satu gelas besar setiap 20-30 menit, dan tiap 20-30 menit itu pula saya ke belakang buang air kecil. Dalam hitungan gelas yang ke-10 akhirnya badan saya berangsur normal. Pada jam 2 pagi, saya yakin sudah sembuh sampai susah tidur menjelang subuh tiba.

Pagi itu dengan tubuh yang masih agak lemas saya berangkat dari rumah dengan penuh semangat untuk mendapatkan pekerjaan yang mapan yang bisa diharapkan kesejahteraannya untuk keluarga. Namun apa yang terjadi ketika wawancara dimulai, dari pihak pengusaha asing tersebut merasa cocok dengan saya, namun gaji yang ditawarkan hanya Rp1.500.000,00 per bulan dengan alasan bahwa pekerjaan di tempat tersebut harus diniati dengan iklas dan sambil beramal. Orang tersebut juga tidak memaksakan saya untuk bekerja di sana namun meminta saya berdiskusi dengan istri saya serta mempertimbangkan apakah cocok bekerja dengan sistem seperti yang ditawarkan. Dalam hati saya langsung menolak namun tidak saya sampaikan seketika itu. 
Setelah wawancara usai langsung saya pulang, dan dalam perjalanan dengan penuh rasa kecewa dan tidak mengingat wawancara itu lagi saya langsung menghubungi teman saya yang menawarkan untuk menjadi pemandu seorang peneliti di mana seleksinya akan dilakukan pada jam 3 sore di hari yang sama. Saya menyatakan setuju untuk ikut dalam seleksi tersebut. Sesampainya di rumah, saya ceritakan seluruh hal yang saya dapatkan dari Semarang kepada istri saya. Respon istri saya menyatakan kalau dia juga tidak setuju saya bekerja di tempat yang jauh namun hasil yang didapatkan tidak seberapa.

Setelah istirahat beberapa saat, berangkatlah saya ke Hotel Jepara Indah di mana peneliti tersebut menginap. Di sana ada tiga kandidat yang ikut seleksi termasuk saya. Dipanggil satu persatu dan diwawancarai menggunakan bahasa Inggris. Dalam wawancara tersebut ada hal penting yang menjadi kriteria diterima dan tidaknya menjadi pemandu peneliti. Pertama adalah bisa berbahasa Inggris tertulis dan secara lisan dan ke dua adalah mengetahui atau menguasai tentang dunia perkayuan atau permebelan karena penelitiannya seputar hal ini. Hampir dari semua pertanyaan itu saya bisa menjawabnya dengan mudah karena memang saya memahami bidang itu.

Pada malam harinya, saya sudah mendapatkan sedikit bocoran dari teman saya kalau ada kemungkinan besar saya yang akan diterima sebagai RA atau asisten peneliti peneliti. Sekitar jam 12 malam, saya mendapatkan SMS kalau saya diterima sebagai RA dan diundang pada pagi harinya untuk bertemu di Hotel Jepara Indah untuk menandatangani kontrak sebagai RA. Hal yang mengejutkan saya ketika pertemuan itu adalah setelah saya tandatangani surat kontrak dan saya langsung menerima 50\% dari kontrak saya selama 2 bulan dengan besaran lebih dari delapan juta rupiah. Seketika itu juga saya mencari informasi kos atau kontrak rumah untuk peneliti tersebut di Desa Tegal Sambi kemudian ngobrol sebentar seputar tugas-tugas yang akan saya kerjakan, sampai pada sore harinya saya pulang dan kabar gembira itu langsung saya kabarkan kepada istri saya. Betapa gembira istri saya sekian lama tidak bekerja kemudian mendapatkan hasil yang tidak disangka-sangka, serta diterima di muka sebelum bekerja. Sungguh Allah Maha Tahu, Maha Pengasih, dan Penyayang hambanya. 
Peneliti ini bernama Anne Prestvick, seorang mahasiswi S3 dari Norwegia yang sedang mengambil gelar PhD-nya dengan mengadakan penelitian di Jepara seputar efisiensi dan berapa besaran penghasilan para perajin yang ada di Jepara. Dalam penelitian ini, saya membawahi 4 enumerator yang terdiri dari para mahasiswa STTDNU dan STIENU Jepara. Saya berperan sebagai konsultan dalam penelitian ini, entry data, serta pengawas para enumerator.

Selama dua bulan bekerja sebagai RA, saya bertemu dengan beberapa pihak yang ada dalam proyek penelitian Furniture Value Chain, orang-orang CIFOR yang terlibat di dalamnya termasuk para asosiasi dan lembaga yang berkepentingan dalam bidang perkayuan dan juga pemerintahan. Pengalaman semakin bertambah, terlibat dalam diskusi-diskusi besar tentang hal-hal yang berkenaan dengan permebelan dan berbagai kehidupan para aktornya.

Setelah dua bulan berlangsung akhirnya kontrak saya usai, namun ada beberapa target jumlah kuesioner yang belum tercapai sehingga ada sedikit tambahan waktu yang mesti saya selesaikan. Setelah dua bulan itu juga saya ditawari oleh pimpinan proyek FVC, Dr. Herry Purnomo untuk ikut berlanjut membantu dalam proyek tersebut sebagai fasilitator di lapangan. Namun saya menyatakan kalau saya masih dalam penyelesaian hasil penelitiannya Anne Prestvick. Tak lama kemudian, kesempatan itu diberikan kepada orang lain dan akhirnya saya kembali sebagai perajin yang belum banyak pengalaman di bidang pemasaran sehingga pesanan pun belum begitu banyak.

Saya kembali kepada kehidupan dan aktivitas seperti biasanya menjadi perajin sambil melakukan aktivitas lain yang menghasilkan pendapatan. Sesekali waktu saya mencoba menyebarkan informasi kalau saya membuka kursus kilat grafis dan bahasa Inggris percakapan. Ada beberapa respon baik yang saya dapatkan, namun sejauh itu masih belum bisa menutupi kebutuhan saya sehari-hari. Hari-hari saya penuhi dengan keinginan beraktivitas yang dapat menghasilkan uang. 
Setelah selesai kontrak sebagai RA saya ikut dalam bagian kecil dari proyek FVC ini yaitu pada proses pembentukan asosiasi APKJ. Namun beberapa pertemuan yang saya ikuti membuat saya berpikir seperti buang-buang waktu dan energi. Hal ini terlintas karena dorongan faktor ekonomi yang sedang tidak stabil. Akhirnya saya tidak kelihatan dalam beberapa pertemuan dan bahkan saat pembentukan APKJ pun saya tidak berada di sana.

Beberapa minggu sebelum APKJ terbentuk, beberapa anggota asosiasi tersebut kursus bahasa Inggris kepada saya sehingga banyak informasi tentang perjalanan pendirian asosiasi. Fasilitator CIFOR yang ada di Jepara pada saat itupun sering meng-SMS saya untuk ikut bergabung dalam asosiasi yang baru terbentuk ini. Dia mengatakan bahwa manfaat yang akan didapat nantinya sangatlah besar. Namun ajakan itu sesekali saya jawab tanpa semangat, dan sesekali tidak saya tanggapi karena fokus pertimbangan saya adalah memenuhi kebutuhan finansial.

Hingga suatu ketika APKJ akan melakukan pameran PPE di Kemayoran Jakarta. Siswa bahasa Inggris saya yang juga berperan sebagai pengurus asosiasi pada waktu itu membujuk saya bersama wakil ketua asosiasi untuk dapat segera bergabung. Beberapa kali saya menolaknya, namun ada sebuah tantangan yang membuat saya setuju, jangan sampai mereka menganggap bahwa ketidakmauan saya ikut dalam pameran adalah karena ketidakpercayaan diri saya dalam berkomunikasi dengan buyer. Akhirnya saya menyetujui dan saya masuk sebagai pengurus sebagai koordinator pemasaran. Sejak itulah saya bergabung dalam APKJ dan mengikuti kegiatan-kegiatannya.

Selama menjadi anggota APKJ inipun tidak ada perubahan secara finansial meskipun diakui banyak teman saya bertambah selain pengetahuanpengetahuan juga bertambah. Hingga suatu hari saya jalan-jalan di Kota Jepara dan entah mengapa saya ingin sekali mampir ke tempat kakek dari istri saya yang ada di Kesa Karangbagusan Demaan, Jepara, mbah Rokhim namanya. 


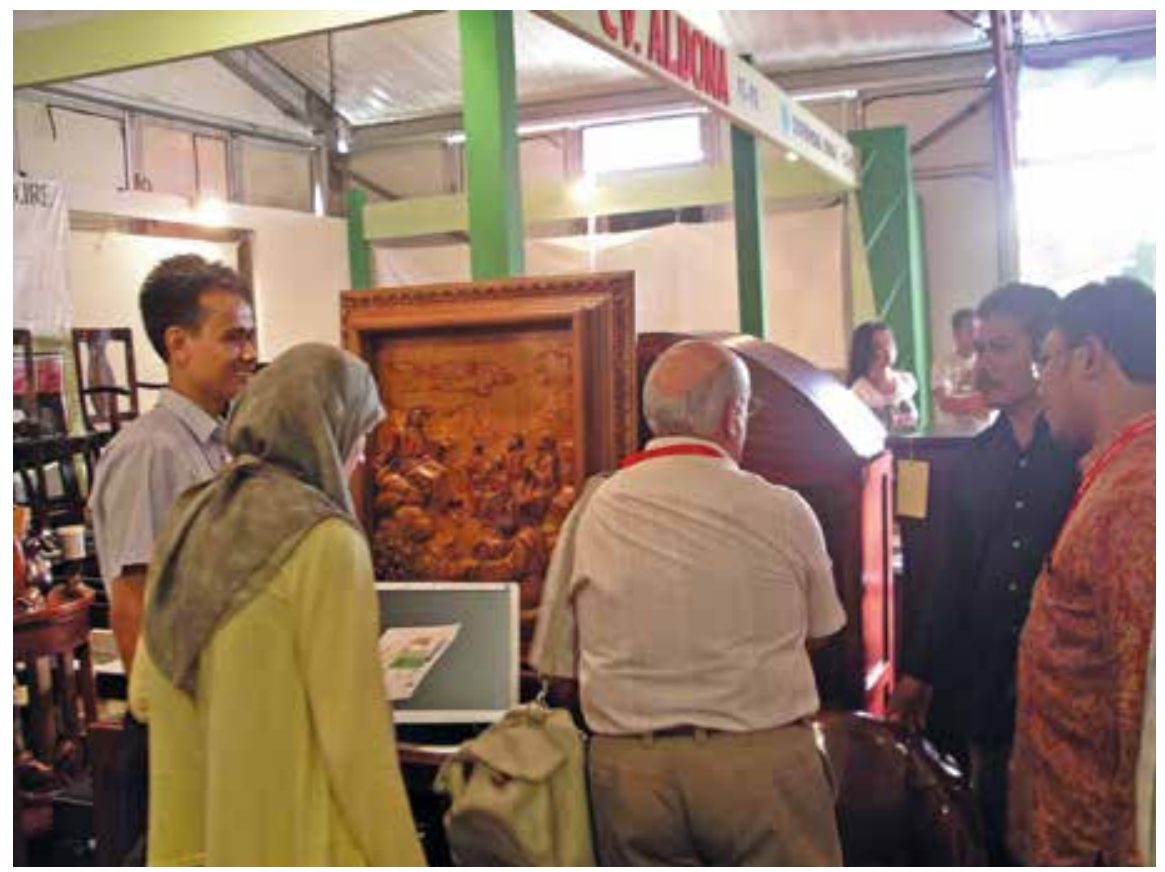

Gambar 2.2. Suasana dalam pameran PPE Kemayoran Jakarta

Siang itu beliau sedang menyapu halaman rumah dan dengan santainya saya menghentikan sepeda motor saya. Tanpa mengawali pertanyaan salam atau yang lain beliau langsung bertanya "Sulthon, gimana kamu sudah dapat pekerjaan atau belum?" Seperti didikte segera saya jawab, "Belum mbah." Dalam benak saya bertanya-tanya, kok mbah Rokhim tahu ya kalau saya nggak punya kerja. Langsung saya dipersilahkan duduk dan tanpa bertanya yang lain beliau memberikan petuahnya bahwa saya disarankan untuk tetap bekerja meskipun hanya mendapatkan upah yang menurut saya jumlahnya sedikit dan tidak sesuai status atau gelar yang saya punya. Membiarkan diri tidak melakukan pekerjaan yang menghasilkan sementara tanggung jawab saya sebagai kepala rumah tangga justru semakin memperpuruk keadaan dan memberikan peluang untuk mempunyai hutang lebih besar. Namun 
dengan bekerja, meski hasilnya kecil akan sedikit menutupi kemungkinan lubang yang akan menjadi lebih besar serta memberikan atau mendatangkan kemungkinan lain untuk mendapatkan peluang yang lebih menjanjikan.

Setelah mendapatkan petuah tersebut di atas, segera sesampainya di rumah, langsung saya memperbaharui lamaran kerja saya yang memang sudah saya siapkan dalam file dengan hanya mengganti nama perusahaan yang dituju serta tanggal pengajuan lamaran. Bergegas dengan membawa flashdisk saya segera ke warnet dan mengirim lamaran tersebut ke beberapa perusahaan hasil browsing di internet. Pada pagi harinya, saya langsung mendapatkan balasan dengan ditelpon langsung dari salah satu perusahaan yang saya kirimi pengajuan kerja tersebut. Kemudian pagi harinya lagi, saya ada wawancara dengan beberapa pertanyaan yang tentu saja dengan mudah saya jawab karena saya berpikir gaji yang standar pastinya akan diberi pertanyaan yang standar pula.

Dari hasil wawancara perusahaan hanya mampu menggaji saya satu juta rupiah. Saat itu saya dipekerjakan sebagai drafter grafis dengan menggunakan program Autocad. Namun pada pagi harinya di saat hari pertama bekerja, tiba-tiba saya ditunjukkan sebuah mesin CNC baru yang dimiliki oleh perusahaan tersebut, dan mereka berencana untuk melatih saya mengoperasikan mesin tersebut. Dalam benak saya mengatakan bahwa saya bekerja di sini hanya sebagai batu loncatan saja sehingga pada saatnya saya mendapatkan kesempatan untuk mendapatkan posisi yang lebih menguntungkan, maka saya akan pindah tempat lain yang lebih menjanjikan tersebut.

Selama bekerja di perusahaan ini, hal yang paling menarik adalah saya dilatih mengoperasikan mesin besar CNC (Computer Numeric Control) sebagai mesin pembuat mebel dengan basis perintahnya melalui komputer. Tidak banyak orang yang punya kesempatan belajar tentang mesin ini, apalagi sampai mengaplikasikannya. Beruntunglah saya mengerti, mempraktikkan, serta mengoperasikan mesin ini. 
Tiba saatnya apa yang menjadi keinginan saya terkabul. Suatu ketika tepatnya hari Minggu di bulan Maret 2009 yang sebenarnya hari itu adalah hari libur, saya dilatih ahli CNC dari Denmark, di mana hal-hal sulit yang sering menjadi kendala para operator mesin tersebut diberikan dan diajarkan hari itu. Tiba-tiba saat istirahat usai pelatihan saya ditelpon mantan bos saya dari Singapura, dia minta saya untuk menanyakan mengenai pesanan bolt tempat tidur kanopi yang dia pesan beberapa minggu sebelumnya. Lebih dari tiga menit lamanya kami ngobrol di dekat toilet kantor. Namun setelah pagi harinya saya masuk kerja, ternyata sepulangnya saya dipanggil ke kantor dan diberi gaji oleh bagian personalia dengan ucapan " "Ini sebagai gaji terakhir dan mulai besok mas Sulthon sudah diperhentikan kerja di sini.” Dengan tidak begitu kaget saya hanya menanyakan, "Kenapa Pak, ada yang salah dengan kerjaan saya?” Dia bilang tidak ada. "Lalu kenapa, Pak?” Dia bilang, "Saya tidak tahu, ini hanya perintah dari bos, saya tidak tahu alasannya."

Usai bekerja di situ, saya sempat bertanya-tanya beberapa hari mengapa dikeluarkan dari perusahaan tersebut. Dari sisi lain saya teringat bahwa doa saya ketika masuk pertama kali yang terlintas ketika saya mendapatkan training CNC adalah minta segera keluar setelah mendapatkan banyak ilmu, karena pekerjaan itu hanya sebagai batu loncatan saja untuk mendapatkan pekerjaan yang lebih baik dari segi finansial, dan ternyata terkabul doa tersebut. Namun di sisi lain, saya teringat kemungkinan karena komunikasi saya dengan orang yang dianggap asing pada saat hari terakhir pelatihan sehingga bos beranggapan bahwa saya akan meniru dan menyebarkan desain miliknya kepada orang lain. Namun apapun kemungkinan yang ada, saya tetap bersyukur telah mendapatkan kesempatan pekerjaan dan pembelajaran yang luar biasa.

\subsection{Menjadi fasilitator lapangan FVC CIFOR Jepara}

Beberapa bulan saya bergabung dengan APKJ dengan mengikuti beberapa kegiatannya, termasuk turut serta dalam berbagai pelatihan yang difasilitasi oleh CIFOR sendiri maupun dari pemerintah. Banyak khasanah keilmuan yang saya dapatkan. Sampai suatu ketika, saya mendengar dari Field Facilitator (FF) kalau saya diinginkan oleh pihak proyek FVC ini untuk 
menjadi FF menggantikan yang lama. Informasi ini pun tidak saya tanggapi serius karena saya merasa pekerjaan ini mungkin akan sangat berat untuk dijalani.

Suatu ketika pihak pimpinan proyek mengontak saya langsung untuk memberikan tawaran tersebut. Saya masih setengah menolak tawaran itu. Alasan saya menolaknya adalah karena idealisme personal mengingat ketidaksukaan saya untuk banyak berhubungan dengan hal-hal birokratis. Dalam benak saya waktu itu, saya merasa sulit berkomunikasi dengan mereka karena karena latar belakang saya dari seorang tukang ukir biasa atau karena pekerjaan yang tanpa kantor dan selalu ada di lapangan dengan tidak dibebani oleh banyak aturan. Alasan yang ke dua adalah, karena FF lama adalah teman baik saya serta saya merasa bahwa orang-orang lama tentu lebih berpengalaman dan tinggal meneruskan saja apa yang sudah diketahuinya. Namun akhirnya, tawaran itupun saya terima dengan segala kekurangan saya dan juga memohon kepada pimpinan proyek untuk selalu memberikan bimbingan atas apa yang sedang dan yang akan saya kerjakan.

Saat awal-awal menjadi FF sepertinya tidak banyak yang bisa saya kerjakan. Pikiran-pikiran normatif saya berawal dari seorang yang bukan seorang peneliti atau tahu banyak tentang kehutanan. Namun seiring waktu berjalan, akhirnya saya tahu apa yang akan dan sedang, serta yang harus saya kerjakan.

\section{Beberapa pengalaman baru selama menjadi FF dan anggota APKJ}

1. Berdiskusi dengan banyak pihak dari berbagai macam latar belakang pendidikan, pengalaman, dan karakteristik serta gaya penyampaiannya. Pengalaman ini memang sudah pernah saya alami sebelumnya, namun terjadi karena adanya persamaan level pendidikan ataupun rata-rata usia. Namun di sini, saya menemui berbagai macam orang dengan keinginan, gaya, bahkan ego yang berbeda. Saya mencoba mempelajari dari apa yang mereka tampilkan, bagaimana gaya para birokrat memberikan sebuah performa di depan publik, bagaimana gaya para akademisi, bagaimana para perajin menyampaikan uneg-uneg-nya, bagaimana praktisi mebel memberikan pengalamannya; semua saya pelajari sehingga hal ini menjadi sebuah masukan positif bagi pola komunikasi dengan mereka. 
2. Beraktivitas tanpa batas ruang dan waktu.

Menjadi FF sama halnya dengan menjadi seorang pelayan. Pelayan banyak orang dengan berbagai ragam keperluan dalam sebuah tujuan luas untuk kepentingan bersama. Perbedaannya sangat jauh dibandingkan dengan aktivitas sebelumnya. Pada siang hari melakukan aktivitas sebagai seorang konsultan dengan bertugas banyak di lapangan, mengenali berbagai jenis permasalahan, berdiskusi dengan para pihak, menyiapkan segala kebutuhan yang diperlukan oleh proyek. Sementara pada malam harinya, terkadang masih melakukan hal yang sama sesuai keperluan, dan malam-malam biasanya lebih berkonsentrasi kepada bisnis pribadi sebagai seorang perajin mebel, begitu selalu adanya. Notebook, blackberry, dan alat pendukung lainnya hampir setiap hari bersama saya, kecuali saat tidur meski biasanya alat-alat kecil masih ada di samping saya.

Memang pekerjaan terasa melelahkan, namun ini adalah perjuangan untuk menggapai cita-cita menjadi manusia yang berguna tidak hanya bagi keluarga namun juga bagi masyarakat luas. Tak peduli bahwa apa yang kita lakukan ini dipandang oleh Tuhan dan manusia adalah baik atau buruk karena Tuhan dan manusia punya ketentuan dan penilaian tersendiri. Namun sebagai manusia biasa, hanya bisa berusaha sepanjang yang kita ketahui itu baik, maka kita berusaha melakukannya.

3. Menjalin kerja sama dengan berbagai macam organisasi pemerintah dan nonpemerintah.

Kemampuan berkomunikasi secara baik tidak setiap orang memilikinya. Membaca suasana hati, menyelaraskan gaya bahasa yang dipakai, sopan santun berdasarkan adat setempat, berusaha memahami bidang dan area tertentu adalah makanan setiap hari yang perlu diterapkan untuk meraih komunikasi yang baik agar terjadi sesuatu yang sinergis. Seorang FF adalah tangan panjangnya proyek untuk dapat mengomunikasikan segala yang diperlukan untuk mencapai tujuan proyek penelitian ini. Diperlukan nafas yang panjang untuk menganalisis berbagai macam karakteristik sehingga mudah untuk dapat bekerja sama. Contoh, kerja sama dengan IWAPI pada akhir tahun 2011-2012 dalam hal pemberdayaan perempuan. Saya sebagai kaum laki-laki berusaha 
berkomunikasi dengan para anggota yang semuanya adalah perempuan dari berbagai usia dan beradat Jawa, tentu saja harus memiliki talenta berbahasa Jawa yang baik, serta berusaha agar apa saja yang kita sampaikan mereka terima dengan senang hati.

4. Pengalaman mengikuti berbagai pameran lokal dan internasional. Saya membayangkan jika pola berpikir saya tertutup, takut dengan perubahan, galau dengan keadaan dan tidak mau bergabung dalam sebuah organisasi, mungkin pengalaman saya tidak sekaya hari ini. Bertemu dengan banyak orang sama dengan menambah keilmuan saya setiap saat. Selama menjadi anggota APKJ saya banyak ditunjuk sebagai duta APKJ dan didampingi oleh teman-teman yang lain bergantian. Pameran pertama kali yang saya ikuti tahun 2009 adalah PPE (Pameran Produk Ekspor), sebuah pameran Internasional yang diadakan di Kemayoran Jakarta setiap bulan Oktober. Saat itu saya masih menjadi pengurus APKJ saja, belum menjadi FF.

Dilanjutkan awal 2010, saya mengikuti pameran Jepara Expo yang ada di Gedung JTTC. Kemudian pameran internasional yang ke dua juga masih di Kemayoran, PPE 2010. Pada bulan Maret 2011 kami mendapat fasilitas untuk dapat mengikuti pameran di IFFINA 2011. Meski stand yang kita miliki hanya kecil saja, cukup banyak pengalaman pameran yang khusus untuk mebel ini. Pada Oktober 2011, kami mendapatkan stand paling besar dari sebelumnya yaitu pada PPE di Kemayoran Jakarta juga. Pada Juli 2012, pameran di Annual Meeting CIFOR juga kami laksanakan atas undangan penyelenggara kegiatan.

Pameran di kegiatan pertemuan tahunan ini sangat laris dengan produk-produk mebel dan suvenirnya. Pameran-pameran ini didanai CIFOR lewat proyek FVC-nya yang mendukung asosiasi sebagai bagian dari skenario moving up-nya. Tujuannya adalah menjadikan para perajin menghasilkan produk-produk mebelnya dan juga mempunyai kemampuan untuk menjual atau memasarkannya sendiri. Saat ini APKJ yang terdiri dari beberapa personal yang sudah terlatih, mampu untuk melakukan pameran sendiri dengan pendanaan sendiri meskipun 


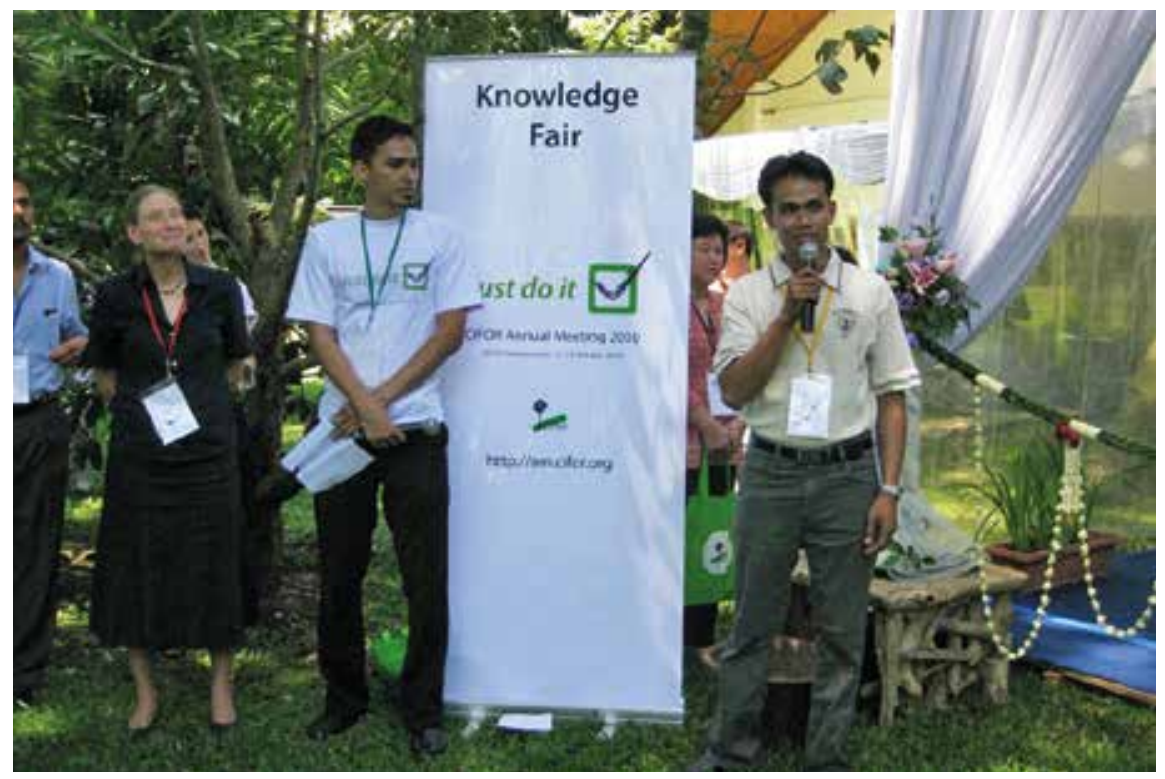

Gambar 2.3. Saya diminta memberikan sambutan pembukaan Knowledge Fair di Rapat Tahunan CIFOR 2010

masih dengan cara gabungan. Perluasan jaringan dengan kementerian serta dinas-dinas yang ada di provinsi serta di daerah Jepara sendiri pun dilakukan untuk mendapatkan fasilitas-fasilitas berupa pameran dan peralatan produksi sehingga manfaat secara kualitatif dapat menyebar luas kepada anggota yang lain.

5. Mengetahui dan meerapkan kebijakan pemerintah secara mandatori akan adanya kebijakan Sistem Verifikasi Legalitas Kayu (SVLK).

SVLK sudah banyak didengungkan sekian lama meski banyak masyarakat Jepara yang tidak mengetahuinya. Berbagi elemen yang ada di kota ini belum menanggapi secara intensif karena isu ini dipandang belum menarik untuk ditindaklanjuti sebagai hal penting yang akan menentukan sebagian nasib tata usaha kayu yang ada di Jepara. 
Pada akhir 2012 dan awal 2013 ini, SVLK menjadi sebuah isu yang paling menarik di antara pengusaha kayu menengah dan atas yang tentu saja berpengaruh erat bagi para pengusaha kecil dan mikro. Bagaimana tidak, karena di Jepara kebanyakan perusahaan menengah dan besar bekerja sama dengan para perajin kecil dan mikro itu sendiri sehingga kebijakan itu mengikat semua elemen yang berkepentingan di dalamnya.

APKJ yang anggotanya termasuk saya menanggapi kebijakan ini secara serius dan mempunyai niat kuat untuk dapat melaksanakan kebijakan tersebut. Sebelum isu ini marak di Jepara, APKJ sudah banyak terlibat dalam pembahasan-pembahasan agar kebijakan ini dapat berjalan baik serta lebih banyak berpihak kepada kepentingan usaha mikro, kecil, dan menengah. Bahkan kebijakan pusat akan adanya SVLK ini sudah banyak diwarnai oleh usulan-usulan APKJ.

Sesuai dengan skenario proyek FVC ini tentang green product, APKJ juga melaksanakan kegiatan sertifikasi SVLK yang prosesnya mengikuti sertifikasi kelompok. Memang lumayan berat mengondisikan para perajin yang tidak terbiasa dengan pendokumentasian usaha mereka. Namun dengan gigih, beberapa anggota yang tergabung dalam kelompok ini mengikuti proses tersebut dengan baik.

6. Pengalaman mendampingi para mahasiswa luar negeri saat magang di CIFOR dan ditugaskan di Jepara.

Meski rata-rata mahasiwa yang saya dampingi dalam penelitiannya menggunakan bahasa Inggris, asal negara mereka menentukan aksen dan gaya bahasa yang digunakan. Bahkan karakteristik yang dimiliki mereka juga berbeda, ada yang toleran, ada pula yang saklek atau leterleg dengan sangat sedikit toleransi.

Anne Prestvick, seorang mahasiswi dari Norwegia adalah orang pertama yang saya dampingi dalam penelitiannya di Jepara pada akhir 2008. Dari pengalaman ini saya mengenal CIFOR, mengenal dunia penelitian, serta membuat saya banyak tahu tentang berbagai organisasi di bidang perkayuan serta personil yang ada di dalamnya. Dalam penelitian ini 
saya membawahi 4 orang enumerator, memberikan supervisi, mengolah data dari kuesioner kemudian melaporkan hasilnya kepada peneliti, Anne Prestvick.

Susan Nansereko adalah seorang mahasiswi Kopenhagen berkebangsaan Afrika. Dalam posisi sebagai Research Assistant ini saya belum menjadi FF FVC, masih sebagai pengurus APKJ saja serta melaksanakan aktivitas sebagai seorang perajin. Dalam penelitian ini saya berperan lebih banyak sebagai pemandu bahasa, mengantarkan peneliti ke mana saja yang ia ingin tuju. Tempat-tempat yang kami kunjungi dan wawancarai banyak ke perusahaan kecil, menengah, dan besar serta ke para penjual kayu, dan para penjual alat-alat perlengkapan/penunjang proses produksi mebel.

Diana Vela adalah seorang mahasiswi berkebangsaan Brasil. Dia sangat ramah dengan masyarakat sekitar. Meski tidak fasih berbahasa Indonesia ia sering berjalan-jalan sendiri di sekitar rumah saya di mana dia tinggal sementara. Sambil membawa kamera dia coba berkomunikasi dengan orang-orang sekitar, hingga suatu ketika dia keluar rumah menjelang hari gelap, seseorang menganggap dia tersesat, lalu orang tersebut menawari untuk mengantar pulang. Dengan hanya menyebut kata Sulthon dengan cepat orang tersebut mengantar sampai depan rumah saya. Penelitian yang dia lakukan kali ini adalah tentang manfaat atau dampak dari berorganisasi. Penelitian ini diarahkan kepada para anggota APKJ dan nonAPKJ.

James Erbaugh adalah seorang mahasiswa Oxford University berkebangsaan Amerika. Dia sangat mudah bergaul karena selain bisa berbahasa Indonesia dengan pengalamannya mengajar hampir setahun di Kota Pati, dia juga suka berolah raga lari di pagi atau sore hari. Dia juga menawarkan kepada teman-teman yang saya kenalkan atau ia temui, dengan senang hati bersedia jika diundang ke suatu institusi/sekolahan untuk sekedar bertemu memberikan motivasi terhadap murid-murid untuk berbahasa Inggris. Penelitian yang dilakukan oleh mahasiswa ini seputar petani hutan dan kehidupannya. Dalam penelitian ini, dia mengontrak 2 orang enumerator alumnus mahasiwa STIENU Jepara, 
Agus Riyanto dan Tas'an. Dalam waktu 30 hari mereka mendapatkan sekitar 300 responden dengan berbagai jawaban sebagaimana pertanyaanpertanyaan yang ada dalam kuesioner.

7. Mendapatkan manfaat kualitatif dan kuantitatif. Masih banyak masyarakat kita yang beranggapan bahwa mengikuti sebuah organisasi dan berbaur dalam sebuah kegiatan hanya buangbuang waktu dan energi saja. Masih banyak pula yang beranggapan bahwa yang disebut hal bermanfaat adalah secara kuantitatif, yaitu berapa besar manfaat finansial yang dapat kita raih. Namun manfaat kualitatif banyak diabaikan.

Suatu hari, saya memberikan kuesioner kepada beberapa perajin baik yang berbasis organisasi maupun nonorganisasi, dalam rangka penelitian beberapa mahasiswa luar negeri yang magang di CIFOR dan bertugas di Jepara. Pertanyaan yang kami berikan seputar manfaat mengikuti organisasi, misalnya bergabung di APKJ. "Apa manfaat yang sudah anda dapatkan selama mengikuti APKJ?" Ada beberapa yang menjawab, "Saya tidak mendapatkan apa-apa, nggak pernah dikasib order oleh APKJ." Pertanyaan lanjutan, "Apakah anda pernah mengikuti training-training yang diberikan atau diadakan oleh APKJ?" dia menjawab, "Pernah." "Kira-kira apa yang Anda rasakan setelah mengikuti training tersebut?". "Ya, sedikit ada pengalaman sih... sama mendapatkan banyak teman." Begitu kira-kira jawaban dari mereka.

Dari komunikasi tersebut di atas dapat disimpulkan bahwa teman-teman masih banyak beranggapan bahwa yang disebut manfaat adalah yang bisa memberikan hal-hal berkaitan dengan uang. Sedangkan hal-hal yang berkaitan dengan keilmuan itu dianggap biasa saja, bukan sebuah manfaat.

Bagi saya pribadi, manfaat yang saya rasakan sangat luar biasa. Secara kualitatif saya mendapatkan banyak ilmu dan pengalaman baru. Secara kuantitatif saya mendapatkan banyak relasi, baik di acara pelatihan, lokakarya, menjalin hubungan kerja sama kegiatan, maupun relasi pada saat 


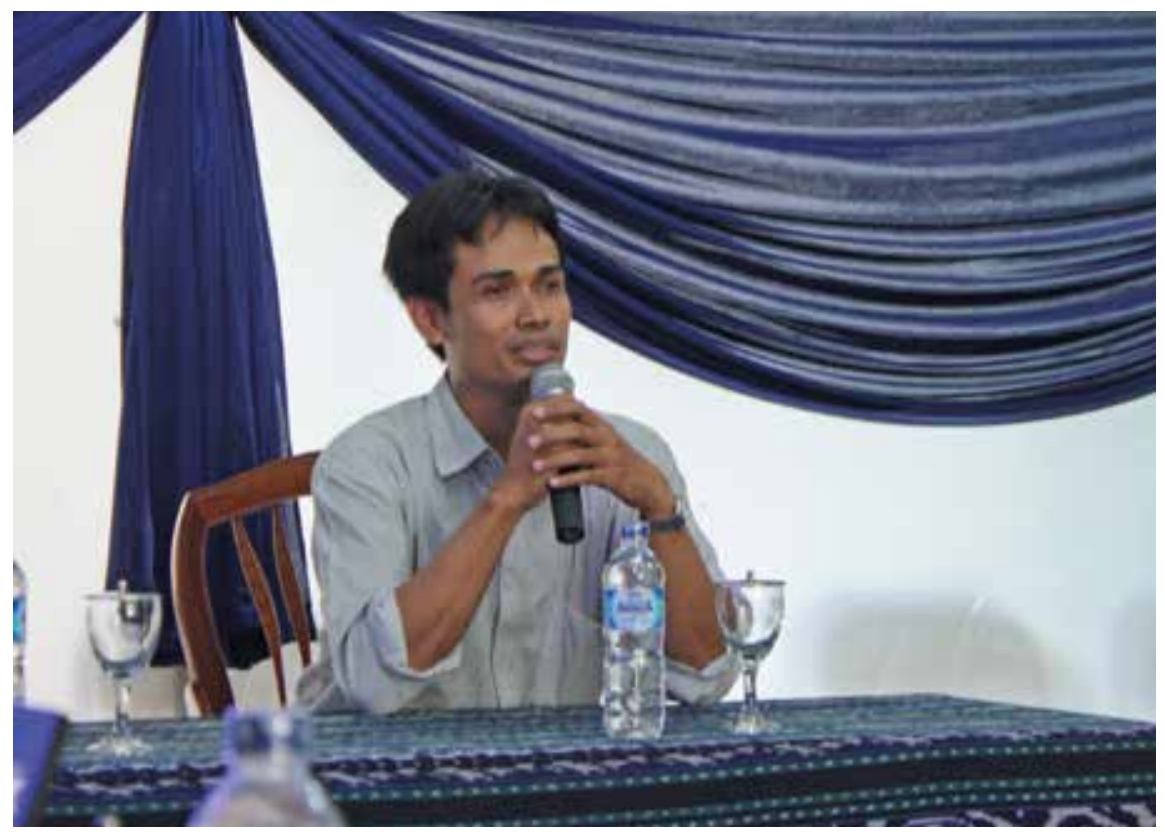

Gambar 2.4. Memfasilitasi pelatihan finishing untuk perempuan

mengikuti acara besar seperti seminar bisnis dan pameran internasional bisa ditindaklanjuti dengan pembicaraan-pembicaraan yang menuju arah bisnis.

Dari bertemu banyak orang dengan berbagai latar belakang itu pula saya mencoba menggabungkan keilmuan yang saya miliki antara menjadi seorang perajin dengan keterampilan desain mebel dan mengekspresikannya dalam bentuk-bentuk grafis serta menerapkannya menjadi sebuah alat pemasaran yang representatif baik yang online maupun offline. Ini membuat produkproduk yang saya miliki sampai saat ini mudah saya tawarkan kepada pelanggan maupun calon pelanggan. Karena banyak hal yang mendukung itulah saya semakin percaya diri dan mantap dalam setiap langkah dalam memasarkan produk-produk saya meski saat ini justru lebih dari 90\% pemasaran produk saya lakukan online. 
Masih banyak hal lain yang tidak bisa saya sebutkan satu persatu sebagai pengalaman yang sangat berharga serta manfaat-manfaat yang saya dapatkan. Dari berbagai pengalaman selama menjadi anggota APKJ dan juga menjadi FF CIFOR, saya bertemu banyak orang dan karakteristiknya; saya mencoba merangkum ilmu yang sekian banyaknya saya dapatkan untuk menyikapi berbagai hal dengan lebih bijaksana. Semoga kisah-kisah yang baik dalam tulisan saya bisa menjadi inspirasi khususnya bagi anak-anak dan keluarga saya. Semoga siapa pun yang membaca kisah saya ini bisa menjadi sebuah inspirasi untuk dapat diterapkan dalam kehidupan bermasyarakat sebagai sebuah contoh pengalaman yang dapat ditingkatkan agar lebih baik lagi. 


\section{Bab 3. \\ Hidup, berusaha, dan mendapatkan sertifikat legalitas kayu}

Oleh: Abdul Latif

\subsection{Masa kecil dan remajaku}

Hari Jum'at Wage bulan Asyura adalah hari yang sangat disakralkan bagi sebagian orang. Bertepatan dengan hari itu tepatnya tanggal 15 Desember 1968, lahirlah Abdul Latif, seorang anak petani desa yang masih jauh dari keramaian kota. Bahkan pada waktu saya lahir, di desa kami belum terjamah listrik. Dari sepuluh bersaudara, saya anak ke-9, saudara wanita 2 orang dan laki laki 8 orang. Sungguh keluarga yang sangat besar bila kita bandingkan dengan keluarga di zaman sekarang. Untungnya, orang tua saya

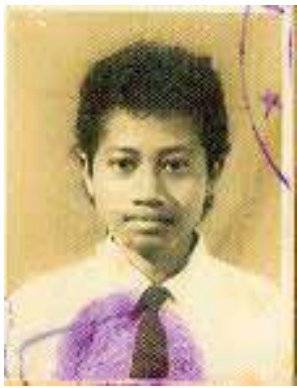

Gambar 3.1. Foto Latif ketika SMP berkecukupan untuk makan sehari-hari.

Kakak saya adalah seorang guru SD di desa tetangga. Sebagaimana cerita Iwan Fals dalam lagunya Oemar Bakrie, kakak saya pergi mengajar naik sepeda onthel menyusuri jalan terjal yang masih berbatu. Saat itu saya pernah diajak untuk ke sekolah karena di rumah tidak ada yang menemani, semua anggota keluarga sibuk dengan urusannya masing-masing; ada yang ke kebun, ke sawah, dan juga pergi ke sekolah. Lama kelamaan saya sering ikut dan saat itulah orang tua saya menitipkan saya bersekolah yang searah dengan tempat kakak mengajar. Waktu itu karena baru berumur lima tahun 
saya merupakan siswa titipan. Hingga saat kenaikan kelas, saya pun tidak diikutkan naik kelas karena belum cukup umur. Di sekolah, nilai saya paspasan saja seperti teman-teman lain. Saat itu ke sekolah masih nyeker (tidak bersepatu). Teman-temanku pun tidak ada yang pakai sepatu dan seragam pun belum punya, tapi kami punya semangat besar untuk bersekolah menuntut ilmu supaya pintar dan kebanyakan dari kami saat itu bercita-cita untuk menjadi dokter.

Selain bekerja sebagai seorang petani, bapak saya adalah guru mengaji. Para tetangga banyak yang datang mengaji pada bapak sehabis maghrib sampai waktu isya tiba. Ada suatu kebiasaan pada keluarga kami kalau waktu maghrib semua anak harus masuk rumah dan sholat berjama'ah di rumah bersama tetangga yang datang untuk mengaji. Karena kebiasaan itu, Alhamdulillah pada saat saya SD kelas 3 sudah bisa khatam al Quran. Setelah sholat isya', tibalah waktu makan malam dan kami sekeluarga harus berkumpul bersama. Mungkin kalau waktu makannya tidak bersamaan, nanti ada yang tidak kebagian karena jumlah anggota keluarga kami ada 12 orang.

Setelah lulus sekolah dasar, saatnya untuk memilih sekolah lanjutan tingkat pertama dan pilihan itu ada di sekolah swasta terdekat yaitu di Kecamatan Mlonggo. Kalau ke sekolah, saya harus berjalan kaki sejauh 10 kilometer pulang-pergi dan melintasi sebuah sungai. Saat itu saya sekolah sore hari. Pagi harinya, saya harus menggembalakan empat ekor kerbau. Selama masa sekolah ini ada hal tak terlupakan, yaitu saya hanya punya satu seragam sekolah dan sepasang sepatu yang saya pakai sampai rusak dan Alhamdulillah masih bisa lulus.

Setelah lulus SMP, saya memilih untuk melanjutkan sekolah. Tapi pilihan ini sebenarnya hanya sebagai pelarian, karena kalau tak melanjutkan sekolah, saya pasti diberi tugas menggembala kerbau seharian dan membantu bertani. Akhirnya, pilihan jatuh pada sekolah lanjutan tingkat atas yang berada di Kecamatan Bangsri. Prestasi saya biasa-biasa saja, di kelas satu saya dapat rangking 22. Namun pada semester berikutnya saya dapat memperbaiki prestasi belajar dan akhirnya di kelas tiga, saya bisa mendapat rangking satu. 
Setelah lulus sekolah lanjutan atas, bangku kuliah memang menjadi dambaan saya dan teman-teman. Saya ingin melanjutkan kuliah di keguruan yang nantinya bisa punya kemampuan untuk mendidik dan dan mengabdi pada negeri tercinta ini. Tapi harapan itu tertunda sampai satu tahun karena masih menunggu kakak saya yang masih duduk di bangku kuliah hingga satu tahun lamanya.

\subsection{Bangku kuliah}

Setelah menunggu selama setahun saya berangkat untuk mendaftar kuliah tanpa sepengetahuan orang tua. Setelah diterima barulah saya beri tahu orang tua, mereka mendukung sepenuhnya. Saya punya sahabat yang hingga kini masih sering berkomunikasi. Saat duduk di bangku kuliah, kami sering menghabiskan waktu dan nongkrong di pinggir jalan bersama. Pada beberapa kesempatan teman saya berkata, "Coba kamu amati pada setiap mobil yang lewat kalau penumpangnya berjejal dan mobilnya jelek, itu bisa dipastikan penumpangnya adalah orang Jawa." Memang seperti itulah yang terjadi di desa kami. Bila mobilnya bagus dan penumpangnya hanya satu atau dua orang, bisa dipastikan penumpangnya bukan orang Jawa. Hal ini terbukti dalam pengamatan selama beberapa bulan setiap kami bersama. Kami iseng-iseng mencoba mencari pembuktian itu dan hasilnya sekitar $80 \%$ benar adanya.

Sepertinya penumpang mobil bagus tersebut kebanyakan bukan pegawai negeri dan bukan seorang guru. Maklum, karena latar belakang pendidikan kami adalah keguruan, maka kami membandingkan dengan kehidupan yang akan dihadapi mendatang. Lalu mengapa kami berjuang keras ingin menjadi guru? Karena menurut kami, peluang pekerjaannya masih banyak, apalagi dengan jurusan bahasa Inggris yang kami pilih.

Hal yang kami pikirkan saat itu adalah bagaimana kami bisa lulus dengan nilai yang baik dan bisa cepat diterima sebagai seorang guru negeri. Memang itu benar, karena yang didengungkan di sekolah sejak duduk di bangku sekolah dasar adalah selalu menjunjung tinggi status seorang guru. Itu memang benar tapi kekurangannya, murid-murid tidak diberi wawasan yang lain, misalnya mengenai perekonomian atau bagaimana misalnya untuk 
berhubungan dengan negara-negara lain. Kalau ada pertanyaan di kelas mengenai cita-cita kamu apa? Maka jawabannya yang banyak adalah ingin menjadi dokter, guru, pilot, dan hampir tidak ada yang ingin jadi pengusaha. Tidak ada teman yang mempunyai jiwa kewirausahaan. Kalau cita-cita kita pilot, mengapa kita tidak cita-cita yang nantinya bisa membayar pilot, bahkan punya pegawai pilot kalau kita punya pesawat pribadi?

Ketika kuliah, ada salah satu dosen saya yang selalu mengritik habis-habisan kondisi negara ini. Dia merasa heran mengapa banyak sekali sarjana yang pengangguran dan selalu kesana-kemari mencari pekerjaan. Buktinya, kalau ada penerimaan pegawai, mayoritas yang melamar adalah sarjana meski peluang untuk diterimanya hanya $2 \%$ bahkan kadang-kadang hanya $0,02 \%$. Dari situ timbul pertanyaan mengapa kita yang diberikan kemampuan berpikir lebih dari orang-orang di sekeliling kita malah jadi begini? Mengapa kita sekolah agar pintar ternyata malah jadi bodoh seperti ini setelah lulus sekolah? Saat itu dosen saya berkata, "Saya berharap setiap mahasiswa saya setelah lulus akan bisa menciptakan pekerjaan dan bukan mencari pekerjaan. Kalau seorang sarjana minimal bisa memperkerjakan tiga sampai lima orang, maka angka pengangguran di Indonesia bisa dikurangi."

\subsection{Berkelana ke Bali dan pulang kampung}

Setelah menyelesaikan bangku kuliah pada tahun 1994, saya menganggur. Kemudian, setelah beberapa bulan berlalu saya ada ide untuk menggunakan ilmu bahasa Inggris dengan datang ke Bali untuk mengadu nasib. Saya mendatangi berbagai instansi dan kantor-kantor. Dari pintu ke pintu, saya membawa map yang berisi fotokopi lembar ijazah dan lamaran kerja tetapi ternyata sulit untuk mendapatkan pekerjaan yang sesuai dengan harapan. Ironisnya, saya malah mendapatkan teman yang sudah mapan dan sehariharinya bisa berfoya-foya menikmati hasil kerja kerasnya hingga saya pun terpengaruh.

Setelah enam bulan berlalu, saya berpikir kalau hidup di Bali memang enak untuk kaum muda tapi saya selalu memikirkan masa depan. Apa jadinya kalau gaya hidup seperti anak muda ini saya jalani terus menerus? Akhirnya 
saya putuskan untuk pulang kampung saja. Sesampainya di tempat kelahiran di Jepara, saya ingin sekali bekerja, tapi harus kerja apa? Lalu ada teman saya yang bekerja menjadi sopir dan saya sering ikut dia. Saya belajar menyetir mobil sampai mendapat SIM A. Dari situlah saya merasa mempunyai keterampilan di luar pendidikan formal yang saya jalani selama ini.

Pada pertengahan tahun 1994, perekonomian di desa saya mulai tumbuh pesat seiring dengan banyaknya produksi mebel yang diekspor ke luar negeri. Saya sebagai anak seorang petani dari keluarga yang tidak punya latar belakang bisnis, belum punya keberanian untuk berbisnis. Saat itu yang bisa saya lakukan hanya jadi seorang sopir colt. Gaji minggu pertama dari hasil nyupir saya belikan kipas angin yang saat itu bisa mengatasi panasnya matahari dan udara Jepara.

Saya bertahan sebagai sopir colt selama dua tahun. Tugas saya mengangkut kayu dan mebel dari penggergajian ke tempat perajin, juga membawa mebel ke gudang yang mengekspor mebel ke luar negeri. Sementara pada malam hari, saya mengantar para pedagang makanan ke tempat orang yang punya hajatan seperti sunatan, pernikahan, dll. Kerja keras seperti itulah yang dapat saya lakukan untuk menghasilkan uang dan sedikit demi sedikit bisa menyisihkan hasilnya untuk ditabung.

Selama itu saya tidak pernah mendaftar menjadi seorang guru walaupun saya berlatar belakang pendidikan guru. Saat itu gaji seorang guru hanya 300 ribu rupiah sebulan untuk golongan $3 \mathrm{~A}$, sementara penghasilan seorang sopir bisa Rp 35 ribu sampai Rp 60 ribu dalam satu hari. Banyak omongan atau cibiran bahwa "Disekolahno adoh-adoh kok cuma jadi supir colt di desa (sekolah tinggi-tinggi tapi kok hanya menjadi sopir colt di desa)?”

Saya berpikiran bahwa kerja apapun tak masalah yang penting halal. Bagi saya, keberhasilan seseorang itu harus dimulai dengan perjuangan ketekunan dan kejujuran. Saya tidak pernah malu menjalani profesi sebagai sopir karena saya punya penghasilan yang lebih besar dari pegawai. Jika saya punya manajemen keuangan yang baik, hasilnya juga bisa lebih menjanjikan. Menabung itu harus dibiasakan sehingga lama kelamaan bisa menjadi 
kebiasaan. Namun, dari perjalanan ini saya tetap berpikir bagaimana agar bisa menjadi pengusaha dan saya tidak mau hanya bekerja menjadi sopir.

Ketika itu usia saya sudah 25 tahun. Teman-teman sebaya saya sudah mulai menikah dan membangun rumah tangga. Saya juga ingin berumah tangga secepatnya pada saat usia masih produktif dan harus dimanfaatkan semaksimal mungkin agar tak tergilas oleh waktu. Karena waktu berjalan terus, pernikahan itu pasti akan terjadi suatu saat nanti, lalu mengapa kita harus menundanya? Apa yang harus ditakutkan? Saya berkeyakinan kalau berumahtangga pasti tetap akan banyak masalah yang dihadapi tapi pada setiap masalah itu pasti ada jalan keluarnya. Jika pernikahan diundur sampai usia matang dan mapan, maka saya mungkin sudah terlalu tua dan pada waktu anak-anak saya butuh biaya sekolah, saya sudah menjelang usia senja dan tidak mampu bekerja lagi. Lalu bagaimana nasib anak-anak saya nantinya?

Akhirnya saya pun menikah. Namun setelah menikah, saya malah menganggur selama enam bulan dan hanya pindah dari tempat mertua ke tempat orang tua secara bergiliran setiap dua minggu sekali. Hingga rasa jenuh itu datang dan daripada menganggur terus, saya kembali menjadi seorang sopir. Kebetulan mertua saya punya truk dan saya mulai bekerja sebagai sopir truk pengangkut kayu randu (kapuk) untuk dijadikan papan cor dan dipasarkan ke Jakarta. Kegiatan menabung tetap saya teruskan hingga akhirnya ada kakak yang usaha mebelnya mengalami kesulitan keuangan dan membutuhkan permodalan.

\subsection{Investasi pada usaha mebel}

Saat itulah saya masuk menjadi investor kecil dengan modal nominal yang bisa dibelikan kayu 8 meter kubik. Istri yang memegang catatan keuangan kegiatan mebel dan saya tetap menjadi sopir truk. Dua tahun usaha mebel itu berjalan. Makin hari makin ada kemajuan dan saya diajak untuk menangani mebel dan berhenti menjadi sopir. Setiap hari kerja saya mengolah kayu mulai dari menyediakan bahan untuk tukang sampai servis atau menyempurnakan mebel sampai laku dijual dan alhasil perusahaaan menjadi semakin maju hingga bisa membeli mobil kijang. Tapi sayangnya pada 
tahun ke tiga, usaha kami mengalami kemunduran hingga jatuh bangkrut. Ada pengalamaan unik ketika menjadi seorang perajin mebel, saat itu saya membeli kayu satu truk untuk membuat bangku yang dijual ke perusahaan besar atau gudang. Naasnya, tidak ada satu pun bangku itu terjual hingga akhirnya diobral.

Seperti umumnya dilakukan oleh perajin mebel, saya pun tidak pernah menyimpan nota pembelian kayu atau surat kayu. Setelah kayu diolah dan dibayar, maka nota dan surat kayu tidak disimpan lagi, yang ada hanya catatan perputaran uang.

Pada tahun 1999, saya menghadapi kendala dalam berbisnis sehingga menyebabkan bisnis saya hancur. Sebuah usaha rumah tangga yang bangkrut berarti tidak ada lagi yang bisa dikerjakan. Beberapa bulan kemudian, saya akhirnya diberi pertolongan oleh Allah melalui Bapak H. Bejo untuk bekerja di perusahaan beliau. Saya tak boleh mengeluh dan berpikir bahwa hidup harus berjalan terus. Dari situlah saya lebih merasakan bagaimana sulitnya menjalani kehidupan sebagai pegawai atau kuli di perusahaan mebel. Saya mengerjakan semua pekerjaan yang ada di perusahaan $\mathrm{H}$. Bejo, mulai dari menyapu, pembahanan, menggergaji, dan lain-lain. Walaupun berijazah S1, saya tidak pernah merasa menyandangnya, semua pikiran tentang gengsi dibuang jauh-jauh agar tidak berpengaruh pada kinerja saya.

Saya bertahan selama 1,5 tahun sebagai karyawan di perusahaan Pak Bejo. Saya memang punya semacam standar bahwa jika saya melakukan sesuatu, saya akan evaluasi setiap tiga atau enam bulan, sehingga saya dapat menemukan kekurangan dan kelebihannya. Kalau dalam waktu satu sampai dua tahun tidak ada perkembangan positif dalam usaha atau pekerjaan itu, maka saya akan mencari alternatif pekerjaan lain. Hidup ini terus berjalan seiring berjalannya waktu. Saya berusaha keras dan berpikir bagaimana agar saya bisa menghidupi keluarga dan keluar dari masa-masa sulit ini.

Selama jeda waktu setelah keluar dari pekerjaan selama beberapa bulan, saya juga mengamati lingkungan sekitar. Kalau semua orang di sekeliling saya ini bisa makan lantas kenapa saya sulit mendapatkannya? Saya tahu jawabannya 
adalah kerja keras tapi saya masih bingung dari mana saya memulai semua itu. Sementara latar belakang pendidikan saya adalah sebagai tenaga pendidik dan saya masih tidak mau untuk terjebak dalam impian Oemar Bakrie.

Ada sedikit cerita yang selalu terkenang di benak saya. Saya mengalami kesulitan menjelang hari raya Idul Fitri dan waktu itu tidak punya penghasilan untuk membiayai anak dan istri. Saya bingung memikirkan anak karena belum bisa membeli baju baru. Jangankan untuk membeli baju, untuk makan saja masih kesulitan. Sehari menjelang hari raya, saya pergi ke tempat mertua untuk silaturahmi bersama anak dan istri. Kami diberi oleholeh seekor ayam untuk kami makan pada hari raya nanti. Kami sekeluarga sangat senang karena di saat seperti ini saya nanti masih bisa menikmati daging ayam. Saya masih berpikir kalau ayam segini hanya digoreng akan habis dalam sekejap. Maka saya berpikir harus dimasak apa ayam ini, sambil saya jalan ke pekarangan belakang rumah dan dikagetkan dengan jatuhnya buah kelapa yang sudah kering di samping saya. Saat tahu bahwa itu adalah buah kelapa yang masih bagus, tiba-tiba air mata saya pun jatuh dan saya menangis dan berterimakasih pada Allah karena dalam masa sulitpun saya diberikan kemurahan jalan oleh Allah SWT.

Saya yang sebenarnya tidak bisa memanjat kelapa tapi Allah jatuhkan buah kelapa di samping saya dan akhirnya kami sekeluarga bisa menikmati makan opor ayam pada hari raya. Sungguh kisah yang tidak bisa saya lupakan. Dari kisah itu saya berpikir dan merenung, bahwa hidup manusia itu memang sudah ada jalannya sendiri. Kita akan dibimbing dan Allah akan memberikan kehidupan. Apalagi kalau kita mau berdoa dan berusaha secara sungguh-sungguh.

\subsection{Perjalanan usaha mebel}

Untuk mempunyai keberanian dalam wirausaha memang tidaklah mudah bagi orang yang tidak punya latar belakang dan berasal dari lingkungan keluarga petani. Banyak sekali pertimbangan yang mendasari itu. Sudah sering saya diajak dan diberi pengertian tentang usaha dari Pak Bejo, tapi masih saja merasakan takut dalam berwirausaha, karena takut tidak punya modal, takut rugi, dan lain-lain. Saya juga mendengar banyak contoh 
bagaimana kehidupan para pengusaha dan kehidupan para kaum buruh di desa sekitar, yang terus berusaha tanpa kenal kata takut dan menyerah. Namun sulit bagi saya untuk memahaminya ketika itu. Sebenarnya contoh itu jelas, tapi untuk menanamkan jiwa wirausaha itu yang sulit. Saya sering diajak jalan-jalan dan diberi contoh nyata dan itu pun sia-sia, tapi ini membuat saya mulai berpikir.

Ada suatu contoh yang membuat saya berani. Banyak di antara pengusaha mebel di Jepara yang tidak berpendidikan tinggi. Bahkan menurut cerita, ada juga yang tidak lulus sekolah dasar. Saya berpikir mengapa saya yang diberi kesempatan belajar sampai ke jenjang sekolah lebih tinggi kok tidak punya semangat seperti mereka? Dari sini saya mulai perlahan-lahan sering memikirkan hal itu.

Dalam kehidupan ini, tidak ada sesuatu yang datang secara tiba-tiba. Saya mulai berpikir bahwa mayoritas kehidupan masyarakat Jepara bergerak di bidang mebel dan mereka bisa melakukannya tidak melalui sekolah mebel atau jenjang pendidikan formal yang lain. Namun mereka bisa mengawali usahanya. Itulah pemikiran yang belum juga saya temukan. Hingga beberapa bulan kemudian, saya semakin sering melihat proses pembuatan mebel. Sampai pada suatu saat, waktu saya mengantarkan mebel ke gudang, saya ikut menyervis sebuah produk mebel dengan maksud agar tahu bagaimana proses membuat mebel.

Saya yakin kalau kita sungguh-sungguh mengerjakan sesuatu, pasti akan menuai keberhasilan dan Allah akan selalu memberi jalan yang terbaik. Intinya, kita tidak boleh melakukan sesuatu dengan sepenggal karena cobaan pasti ada, sandungan juga pasti ada, dan yang tak kalah penting, kita tidak boleh berputus asa dan terus mencoba tanpa mengenal lelah.

Pada pertengahan tahun 2001, sebelum menekuni dunia pasar mebel, saya berkonsultasi pada istri terlebih dahulu. Saya minta dukungannya sepenuhnya karena yang saya lakukan adalah untuk keluarga. Kalau saya mau menekuni usaha mebel perlu perjuangan keras yang memerlukan waktu sangat banyak. Saya bilang kalau saya akan meluangkan seluruh waktu 
untuk bekerja selama 24 jam dan istri saya setuju karena mungkin tidak ada pilihan lain.

Saya mencoba pergi jam 6 pagi karena harus mencapai rumah perajin jam 7. Saya berkeliling setiap hari ke rumah para perajin dan kalau siang saya mampir di masjid sekalian untuk sholat dhuhur dan istirahat sejenak. Pulang sampai rumah minimal jam 7 malam. Jika pada malam hari ada telpon saya pun harus menjawabnya dengan segera dan konsentrasi kembali ke pekerjaan. Jadi bisa dibilang total waktu dan tenaga saya habis untuk pekerjaan.

Saat memulainya dengan menjadi makelar mebel dan sebuah sepeda motor vespalah yang menemani saya kemana pun pergi. Namun suatu saat saya harus menjualnya karena butuh alat komunikasi seperti telpon genggam (HP). Motor itu laku seharga Rp1.100.000,00 dan itupun saya dibayar Rp 900.000,00 dulu, lalu saya berangkat ke Semarang untuk beli HP. Saya habiskan Rp750.000,00 untuk HP dan sisanya untuk beli celana.

Ada sesuatu yang unik juga karena saat itu saya punya alat komunikasi tapi tidak mempunyai alat transportasi (sepeda motor). Lalu saya memanfaatkan momen karena saya punya 10 saudara dan mereka mayoritas mempunyai sepeda motor sehingga saya membuat jadwal untuk kunjungan ke perajin dan jadwal pinjam sepeda motor. Jadi saya pinjam sepeda motor setiap hari kepada saudara-saudara secara bergantian, kadang saya belikan bensin kadang tidak. Walaupun kakak-kakak mengizinkan saya pinjam, lama-lama saya merasa malu, karena itu saya berusaha keras untuk bisa membeli sepeda motor sendiri.

Sedikit demi sedikit dari hasil kerja itu saya tabungkan untuk bisa membeli sepeda motor. Namun terasa berat karena hasil dari makelaran mebel itu hanya cukup untuk makan sekeluarga. Di tengah pergelutan saya dengan dunia mebel, suatu hari saya dibantu oleh Bapak Haji Bejo Raharjo.

Beliau memberikan order sekaligus deposit uang muka untuk mengerjakan pesanan mebel. Jadi bukan cuma semangat yang dia berikan, melainkan 
juga ibaratnya memberikan kail dan umpannya. Hasil dari pesanan tersebut membuat saya bisa mendirikan brak di depan rumah seluas 10 x 15 meter. Kemudian saya meneruskan profesi di bidang mebel ini dengan lebih giat berkeliling wilayah Jepara sambil mencari peluang. Usaha saya tidak hanya melayani penjualan mebel outdoor tapi juga melayani penjualan indoor.

Pada pertengahan tahun 2002, saya dipertemukan teman dengan pengusaha mebel yang ada di Semarang, namanya Pak Taufik. Dia adalah pemilik perusahaan bus PO Shantika. Saat proses negosiasi ke Semarang itu ada peristiwa yang sangat menyentuh. Sewaktu akan berangkat ke Semarang, anak saya sedang sakit dan harus berobat ke puskesmas. Saya tetap berangkat meninggalkannya karena semangat untuk bekerja. Setelah melalui beberapa negosiasi akhirnya berhasil dan kami mendapatkan pekerjaan itu.

Pada saat pertama kali mengerjakan order dari Pak Taufik, saya diberi pesanan produk mebel sebanyak dua kontainer dengan jangka waktu 2 minggu harus selesai. Alhamdulillah berkat izin Allah, pesanan tersebut bisa saya penuhi. Pada tahun berikutnya, saya diberi order hingga delapan kontainer dan kemudian berkembang terus sampai saya bisa membeli mobil pada tahun 2004. Saya juga bisa memiliki tempat usaha yang lebih lebar sekitar $300 \mathrm{~m}^{2}$, namun sayang pada tahun berikutnya usaha mengalami penurunan dan bisa dikatakan bangkrut. Bahkan waktu itu, saya punya hutang sekitar 150 juta rupiah. Syukur kepada Allah Maha Kuasa, saya bisa terbebas dari hutang itu dan akhirnya bisa bangkit kembali.

Pada tahun 2004, saya mulai memasarkan mebel di Yogyakarta. Ada beberapa perusahaan yang bisa saya pasok. Selama beberapa tahun, saya bisa menambah pelanggan sampai ke Solo. Kelancaran usaha itu berlangsung sampai 3 tahun hingga akhirnya ada gempa di Yogya pada tahun 2006 dan semuanya berakhir. Tiba-tiba teman lama saya sewaktu sekolah di Malang datang bersama pembeli dari Perancis. Kami bisa bekerja sama tapi bertahan hanya dua tahun. Kemudian saya tidak ada komunikasi lagi dengan teman tersebut. Saya tadinya sudah melupakan semua tentang kerja sama kami, tetapi selang dua tahun kemudian, pembeli yang dibawa teman itu datang lagi. Dia banyak bercerita tentang perjalanan kerja sama dengan 
teman itu dan menyebutkan bahwa ia melakukan korupsi sehingga maksud kedatangannya mencari saya adalah untuk mengajak kerja sama. Dalam kerja sama itu saya mau, tapi saya minta gaji bulanan dan produksinya harus di tempatku. Hal itu terjadi sampai sekarang, tapi untuk gaji bulanan hanya bertahan selama dua tahun.

\subsection{Mengenal APKJ}

Dengan segala kemampuan, saya tetap bertahan sebagai pengusaha mebel skala kecil dengan berbagai suka dan dukanya. Hingga pada akhirnya, Pak Yoyok mengajak saya untuk bergabung berorganisasi di APKJ. Saya mau bergabung asal hanya sebagai pelengkap atau sebagai anggota biasa saja. Jadi saya sering diajak kalau ada pertemuan di kantor dan didukung oleh Pak Legiman hingga sewaktu ada pameran di PPE, saya dipercaya teman-teman untuk ikut ke Jakarta dan membantu dalam penyelenggaraan pameran. Dari situ saya punya pengalaman bagaimana menangani tamu dan bagaimana bernegosiasi langsung dengan pembeli.

Saya adalah anggota yang paling tidak punya suara karena saya tidak punya banyak pengalaman dalam berorganisasi dan kurang percaya diri dengan kemampuan saya sendiri. Pada bulan Oktober 2011, saya mulai mendirikan usaha yang berbadan hukum yang kami namai CV. Mebel Jati Jepara. Saat itu ada seorang pembeli dari Perancis yang memberikan order tapi tidak memberi uang muka. Saya menawarkan jalan keluar kalau tanpa uang muka maka saya meminta pembayaran dengan LC (Letter of Credit) dan akhirnya sepakat. Konsekuensinya saya harus punya perusahaan yang berbadan hukum sebagai syarat penerima LC.

Pada tahun pertama, saya terima LC dan mengerjakan order, berarti saya menduduki posisi baru saya sebagai eksportir sungguhan, karena semua dokumen ekspor atas nama saya. Perusahaan ini baru dan pemberangkatan kontainer yang pertama di bulan Januari 2012 mengalami berbagai tantangan dalam ekspor karena ada kebijakan baru pemerintah mengenai NIK (Nomor Induk Kepabeanan). Semua perusahaan mebel yang ada di Jepara kelabakan dengan adanya kebijakan baru ini hingga banyak kontainer 
yang tertahan di pelabuhan hanya karena menunggu NIK. Namun syarat ekspor ini harus dipenuhi dan Alhamdulillah saya bisa mendapatkannya gratis melalui mediasi Asmindo dan Pemda Jepara yang mendatangkan para pejabat pembimbing pembuatan NIK dari Jakarta untuk datang di pendopo Kabupaten Jepara.

Belum lama kami disibukkan dengan peraturan ekspor baru, kami lalu dikenalkan sistem ekspor yang baru lagi yaitu SVLK yang akan diberlakukan bulan Maret 2013, tapi untuk produk mebel dari kayu jati dan mahoni berlaku pada Januari 2014. Kami semua selaku pelaku ekspor Jepara benarbenar stres dengan adanya peraturan baru yang berganti-ganti tersebut. Untungnya CV Mebel Jati Jepara sebagai perusahaan baru tentunya masih mempunyai semangat baru pula. Saya harus tetap maju untuk mempertahankan usaha. Kami semua ingin menjadi eksportir yang tangguh dan tidak melempem dengan adanya banyak ujian yang beruntun, karena kami yakin dengan adanya kesulitan ini bila bisa melaluinya maka semakin besar peluang untuk memenangkan kompetisi bisnis ini.

Pada tahun 2012, SVLK masih sulit di terapkan pada UKM di Jepara. Karena setelah kami pelajari, semua aturannya menggunakan tolok ukur perusahan besar dan standar internasional. Jika diterapkan untuk perusahaan yang kecil masih banyak ketimpangan atau banyak ditemukan ketidaksesuaian. Untuk bisa diterapkan pada perajin kecil, pemerintah mengadakan kajian di Jepara yang salah satunya lewat Javlec. Javlec melakukan pendekatan pada APKJ yang mempunyai banyak anggota perajin kecil yang ada di Jepara.

Akhirnya Ditjen BUK (Bina Usaha Kehutanan) Kementerian Kehutanan mengadakan rapat di Bogor, di Hotel Permata, pada tanggal 20 Juli 2012 untuk mengusulkan beberapa perubahan Perdirjen mengenai SVLK dengan mendatangkan beberapa pihak. Di antaranya yang hadir dari kami adalah Pak Margono selaku ketua APKJ dan saya, kemudian dari Asmindo dan dari seluruh komponen yang berkaitan dengan implementasi SVLK. 


\subsection{Penolakan SVLK Kelompok untuk CV Mebel Jati Jepara}

Pada bulan November, Javlec mengadakan pendampingan bagi SVLK kelompok dan dari APKJ banyak yang antusias mengikuti, termasuk saya. Akan tetapi, hanya perusahaan saya yang tidak diperbolehkan mengikuti SVLK kelompok. Saya dikatakan tidak boleh ikut SVLK kelompok dengan alasan perizinan-perizinan perusahaan saya sudah termasuk usaha menengah. Sebagai sesama anggota APKJ, saya merasa iri karena tak boleh ikut SVLK kelompok, apalagi program ini gratis karena dibiayai pemerintah.

Namun saya tetap bersikukuh untuk mengikuti aturan SVLK secara mandiri walau harus membayar biaya yang begitu besar. Menurut informasi yang saya terima, biayanya mencapai $\mathrm{Rp} 30$ juta ditambah biaya pendampingan dan lain-lain sehingga kalau ditotal biayanya mencapai minimal Rp 60 juta.

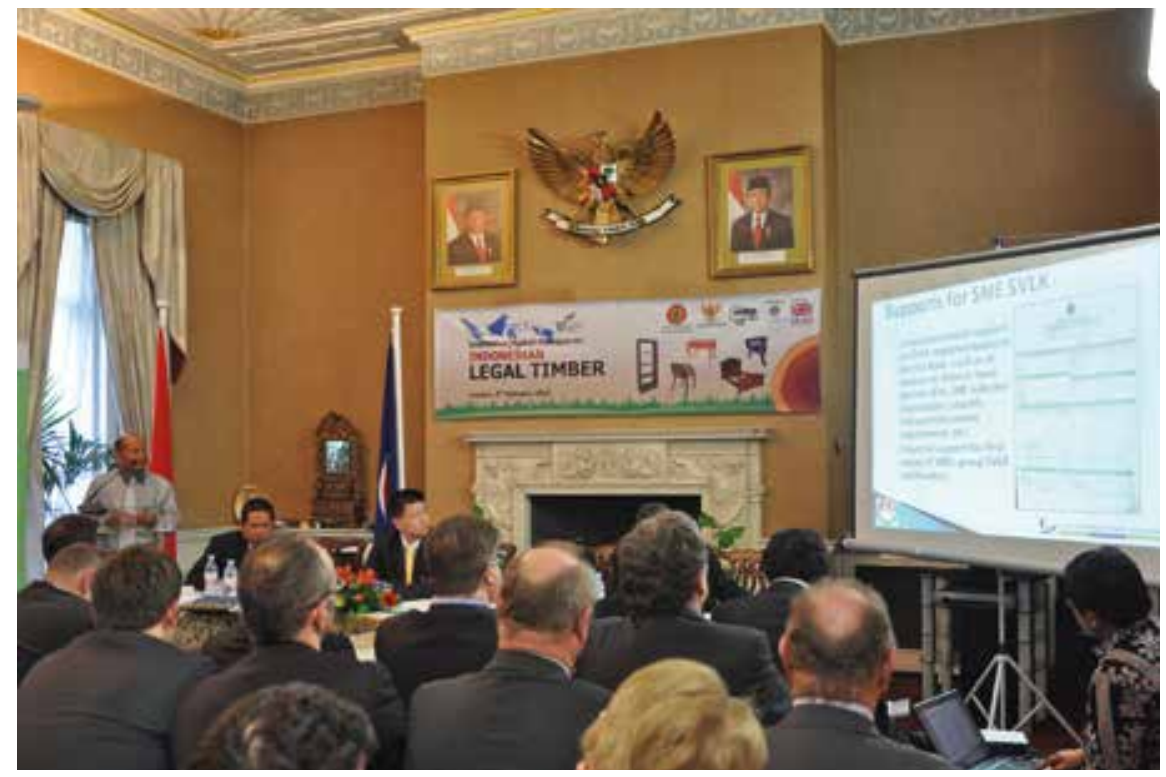

Gambar 3.2. Menjadi pembicara dalam acara market dialog di Kedutaan Besar Republik Indonesia di London, tahun 2013 


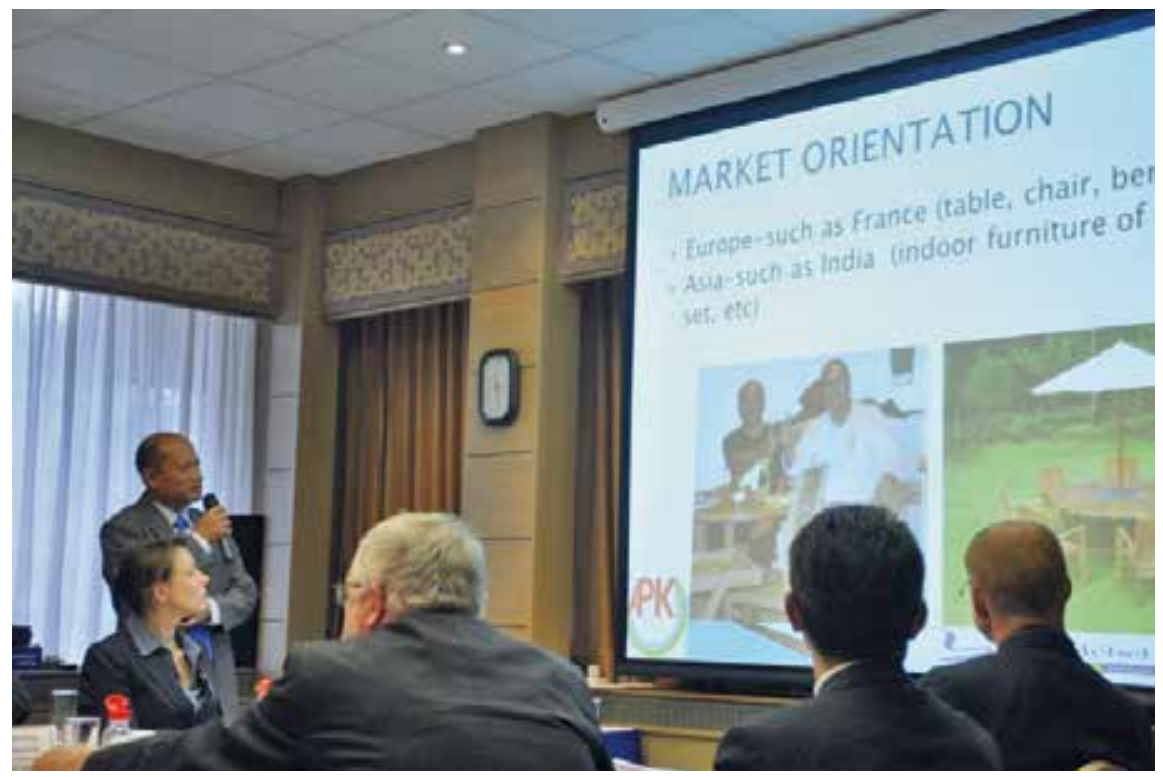

Gambar 3.3. Presentasi dalam acara market dialog di Kedutaan Besar Republik Indonesia di Brussel, Belgia, tahun 2013

Menurut saya, biaya ini harus ditanggung perusahaan karena sifatnya wajib dari pemerintah kita.

Saya merupakan satu-satunya perajin kecil yang berani mengajukan SVLK secara mandiri. Untuk mendapatkannya, persiapannya memang memerlukan perjuangan besar, di antaranya saya harus menambah tenaga administrasi sampai dua orang untuk menyiapkannya. Saya tetap berkeyakinan bahwa Allah akan selalu membuka jalan bagi hamba-Nya yang berusaha keras memperjuangkan keinginannya. Semangat saya untuk maju terus pantang mundur karena saya yakin semua masalah pasti ada jalan keluarnya. Tahap demi tahap persiapan untuk melengkapi segala kebutuhan yang berkaitan dengan SVLK bisa saya penuhi hingga akhirnya pihak pendamping menyatakan bahwa kami bisa melanjutkan persiapan dengan didampingi pihak Javlec dengan bantuan dari MFP-DfID. 
Pada bulan Desember 2012, saya diundang MFP untuk mengikuti lokakarya di Yogyakarta dengan tema pengaruh SVLK pada kemiskinan atau Poverty Impact Assesment (PIA) yang dihadiri Michael dari Inggris. Di sana saya juga diberi tugas untuk mempresentasikan mengenai semangat dari CV Mebel Jati Jepara dalam kapasitasnya sebagai pengusaha/perajin kecil yang sudah punya semangat dalam mengikuti SVLK beserta masalah serta langkah yang dihadapi dan dilakukan dalam menyiapkannya. Salah satu usaha kami adalah melakukan belajar bersama teman-teman di lingkungan CV Mebel Jati Jepara pada setiap hari Jum'at pada saat kami libur bekerja.

Pada bulan Februari 2013, saya mewakili CV Mebel Jati Jepara yang diberi kesempatan oleh MFP untuk diajak perjalanan ke London dan Belgia untuk mewakili SMEs (Small and Medium Enterprises). Perjalanan pertama kami di London dengan agenda pertemuan dengan para perwakilan Pemerintah Inggris yang berkaitan dengan regulasi kayu dan importir kayu di Kedutaan

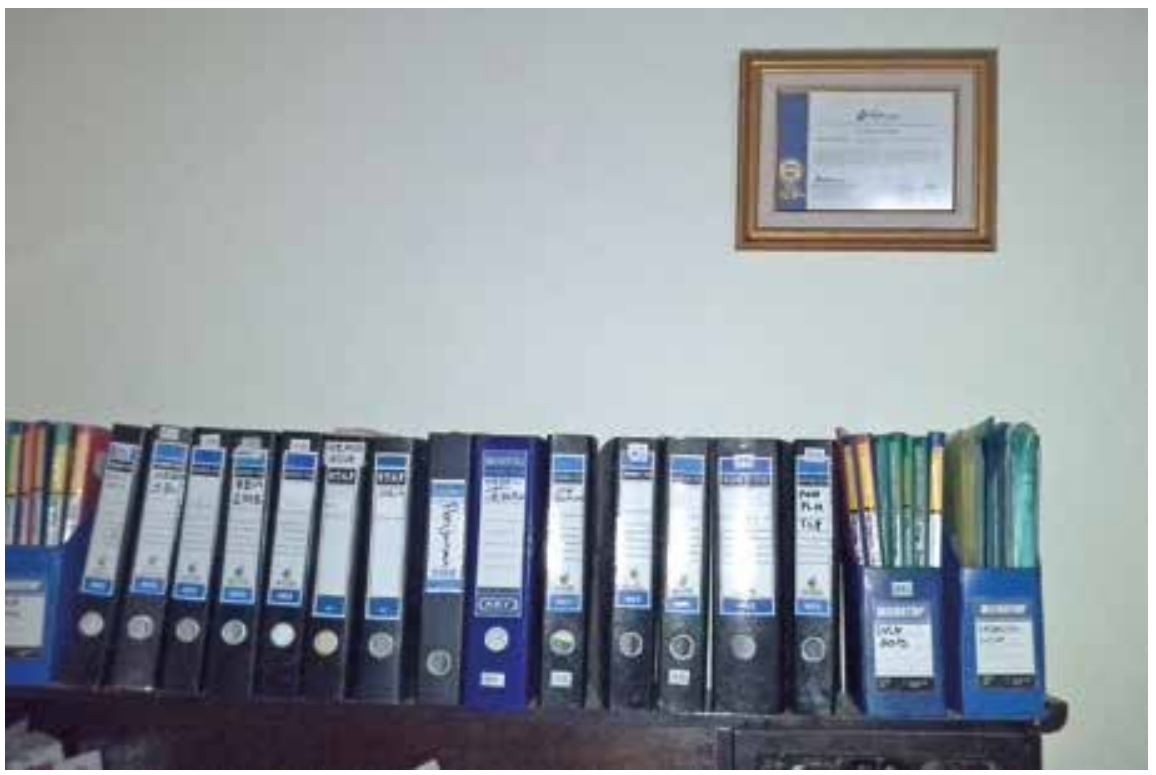

Gambar 3.4. Sertifikat SVLK menghiasi ruang kerja saya 
Besar Inggris. Di sana saya memaparkan keikutsertaan perajin kecil dan APKJ yang sangat antusias mengikuti SVLK di hadapan sekitar 60 peserta.

Kemudian pada hari berikutnya, kami berangkat ke Belgia untuk bertemu Duta Besar Belgia dan sekali lagi memberikan presentasi di hadapan para importir dan juga perwakilan dari Greenpeace.

Sepulang dari lawatan dari beberapa negara di Eropa, saya langsung menyiapkan audit SVLK yang diselenggarakan tanggal 18 Maret 2013 dengan auditor dari PT. Mutu Agung Lestari dan selesai tanggal 20 Maret 2013.

Dari pengalaman saya di atas, ada beberapa hal yang bisa digarisbawahi bagi siapa pun yang ingin memulai berwirausaha. Pertama, mantapkan hati dan jangan ragu-ragu untuk melangkah. Ketekunan dan keuletan bisa menjadi modal awal seorang wirausahawan. Jangan terlalu terpaku pada latar belakang pendidikan, jalani apa yang bisa dilakukan, meski dimulai dengan hal kecil, jika ditelateni maka akan memberikan peluang menjadi besar. Ke dua, jika sudah memulai usaha, jangan setengah-setengah atau mudah putus asa. Tantangan dan hambatan pasti ada, namun jangan menjadi alasan untuk menyerah dan harus dijadikan semangat untuk terus berpikir dan mencari solusi pemecahannya. Ke tiga, setelah berusaha sekuat tenaga, jangan lupa untuk terus berdoa. Usaha keras yang disertai doa sungguh-sungguh Insya Allah akan memberikan hasil yang sepadan. 


\section{Bab 4.}

Mengukir mimpi meraih prestasi

Oleh: Legiman Arya

Keberadaan UKM (Usaha Kecil Menengah) di lingkungan dunia kewirausahaan sudah tidak diragukan lagi. Perhatian baik dari instansi pemerintah maupun lembaga lain terkait di luar pemerintah sangat luar biasa dalam pembinaan dan programnya. Namun tidak sedikit pula yang luput dari sentuhan dan perhatian lembaga-lembaga tersebut karena keterbatasan anggaran serta kendala lainnya. Kemandirian UKM dalam meningkatkan kapasitas usaha merupakan salah satu solusi dari keterbatasan pemerintah dalam programnya.

Jepara memiliki UKM dalam jumlah yang banyak, terutama di bidang perkayuan dan hal ini menjadi perhatian serius pemerintah Jepara. Salah satu lembaga yang telah menyentuh perajin kecil kayu Jepara adalah CIFOR dengan program FVC serta lembaga APKJ yang pembentukannya difasilitasi olehnya. Harapannya adalah untuk memperbaiki keadaan perajin kecil kayu Jepara baik dari sisi peningkatan pengetahuan kewirausahaan melalui pelatihan-pelatihan, mendapatkan suara dan posisi yang sama dalam program roadmap kebijakan mebel Jepara, kegiatan penguatan pasar dengan program pameran atau masih banyak lagi yang lain. Namun peran dan upaya itu tidak cukup tanpa diikuti upaya dari diri UKM itu sendiri. Mengantisipasi kompetitor mewajibkan UKM lebih siap dalam kapasitas dan harus belajar serta dapat memetakan apa yang menjadi masalah serta 
kebutuhan yang harus diselesaikan supaya dapat meraih mimpi dan apa yang dicita-citakan. Ada tiga hal umum yang harus dipenuhi dalam meraih mimpi itu: peningkatan penghasilan, peningkatan kapasitas diri dan memperluas komunitas, serta berpikir prestasi dan doa.

Saya termasuk pemilik UKM di Jepara yang kondisinya tergolong di bawah. Namun ada keinginan besar bagi saya untuk maju dan mengubah perilaku, cara berpikir, memilih pekerjaan dan berkomunitas. Langkah demi langkah mulai dijalankan.

\subsection{Riwayat hidup}

Saya terlahir di Pati dari keluarga sederhana. Bapak saya seorang kepala desa yang sebelumnya bekerja di bidang kesehatan. Setelah besar, saya baru tahu ternyata beliau yang saya kenal sebagai bapak ternyata adalah paman saya, Supardjan nama beliau dan bapak kandung saya adalah kakak kandung paman saya tersebut bernama Sularyo.

Sewaktu saya duduk di kelas 3 SMP, ada keinginan sekolah dengan biaya sendiri, tapi ditolak bapak karena mungkin merasa malu karena merasa masih mampu membiayai. Namun saya tetap berusaha untuk membiayai sekolah sendiri. Waktu itu, saya memiliki angan-angan untuk menjadi seniman tingkat dunia dan bisa sekolah di Italia. Saya terinspirasi dari sebuah artikel di majalah yang saya sudah lupa namanya. Namun saya berpikir, tidak mungkin orang tua sanggup membiayai. Oleh sebab itu, saya ingin tetap bersekolah dengan biaya sendiri sampai tingkat yang setinggi-tingginya. Ke depannya, jika sekolah ke jenjang yang lebih tinggi saya berpikir dapat membiayai sendiri dengan biaya yang tentunya ikut naik sebanding dengan tingkat pendidikan.

Bermodalkan uang Rp 400 ribu, saya membuat sumur untuk dijual airnya di daerah saya yang waktu itu kesulitan mendapatkan air. Dibantu empat orang tenaga, saya jual air bersih dari sumur itu ke tetangga sekitar rumah. Sampai akhirnya mendapat pelanggan tetap dan hasilnya berlebih untuk membiayai sekolah saya. Kegiatan ini distop bapak ketika menjelang ujian, karena bapak berharap saya konsentrasi di ujian kelulusan dulu. 
Sebelum melanjutkan sekolah, saya mencoba mencari pengalaman ke Jepara. Konon katanya, ayah dari nenek saya berasal dari daerah Pecangaan Jepara, namun karena kurang komunikasi dan silaturahmi dengan kerabat di sana, saya kurang tertarik untuk mengetahuinya. Kurang lebih selama enam bulan saya belajar ukir kayu secara berpindah-pindah dan akhirnya pergi ke Kota Malang untuk bekerja pada seorang kontraktor bidang interior etnik dan ornamen. Bos saya waktu itu tidak tahu kalau saya sebenarnya baru belajar mengukir. Dari situlah tantangan selalu saya hadapi. Pak Deddy, begitu biasa beliau dipanggil, selalu memberi pekerjaan yang saat itu tidak mungkin saya kerjakan karena beliau tidak tahu kalau saya bukan ahli mengukir. Tantangan demi tantangan saya hadapi akhirnya suatu malam saya berpikir bagaimana untuk menghadapi semua pekerjaan ini.

Saya mendapat ide untuk mencari tenaga terampil ukir dari Jepara dan akhirnya disetujui untuk menambah tenaga ukir. Empat orang lulusan SMIK Jepara (Sekolah Menengah Industri Kerajinan yang sekarang berubah menjadi Sekolah Menengah Kejuruan Negeri), saya pekerjakan untuk membantu saya dalam tim prototipe mebel dan ornamen interior properti. Dari situ saya belajar dari mereka yang bekerja pada tim yang saya pimpin. Dalam waktu kurang dari enam bulan, saya bisa menyamai ketrampilan mengukir mereka dan tidak lama setelah itu, saya sudah dapat membuat karya seni dari kayu.

Suatu ketika ada proyek mereproduksi ukiran-ukiran yang ada di Puri Agung dan Puri Gede di Karang Asem, Bali yang sudah rusak. Orang Bali sendiri tidak berani membuat ukiran itu karena katanya angker menurut kepercayaan mereka. Dari situlah saya kenal Bapak Wayan Sadru yang ternyata ahli dan seniman ukiran kayu. Pada saat itu, saya diperbolehkan mendalami seni ukiran dari beliau di luar jam kerja serta pada malam hari. Tiga bulan lebih waktu yang saya butuhkan untuk menguasai ilmu ukiran kayu dari sanggarnya. Namun bagi saya itupun belum cukup. Saya mengambil pendidikan ukir kayu dengan cara otodidak karena saya ingin mendalami ilmu lain dan cara ini prosesnya cepat jika memiliki kemampuan bakat seni kuat. 
Sewaktu di Malang, saya berusaha melanjutkan sekolah di ABM (Akademi Bisnis Manajemen) tapi tidak selesai. Lalu saya kembali ke Jepara karena keadaan di Malang yang tidak mendukung saya untuk berkembang di bidang usaha ukiran. Saya memiliki rencana untuk membuat usaha sendiri. Di Jepara ternyata banyak tantangan yang harus saya hadapi, dari pekerjaan sebagai tukang ukir yang ternyata memberikan hasil kurang dari yang saya harapkan. Akhirnya, saya gabungkan mesin dengan keahlian mengukir, lalu saya mengambil kredit di KUD Mintorogo untuk membeli sebuah gergaji mesin. Setelah mengukir dengan gergaji mesin, saya dapat penghasilan antara Rp 300 ribu sampai Rp 400 ribu perhari. Tapi tidak setiap hari saya bekerja menggergaji karena ada pekerjaan lain yang harus saya lakukan. Akhinya saya dapat berkembang dan berorganisasi di sentral itu (Organisasi Centra Industri) serta mendirikan perusahaan jasa ukir usaha dagang (UD) Gajah Sungging Carving.

Pada akhir tahun 2008, dua hari sebelum hari raya Idul Fitri saya mengalami kecelakaan sepeda motor. Akibatnya, kedua lengan yang merupakan andalan untuk menggergaji ukir dan memberikan penghasilan yang lebih dibanding teman-teman pekerja lainnya menjadi tidak dapat digunakan untuk bekerja. Hampir setahun masa penyembuhannya. Saya hampir putus asa akan kesembuhan lengan ini karena keduanya patah. Tapi Tuhan berkehendak lain, tangan saya akhirnya sembuh seperti tidak pernah luka walau kadang nyeri linu-linu jika kelelahan.

Akhir tahun 2009, saya berpikir untuk memiliki keahlian lain yang mendukung keahlian mengukir saya. Lalu saya mengikuti berbagai pelatihan termasuk teknologi informasi dan ekspor yang diselenggarkan oleh organisasi dalam maupun luar negeri. Akhirnya, saya bergabung dalam organisasi APKJ.

Tidak ada yang istimewa pula apa yang saya alami, tidak ada perencanaan dan semua berjalan apa adanya seakan saya lupa dengan angan-angan dan cita-cita di waktu kecil yang bermimpi menjadi seniman dunia. Saya hanya berpikir berusaha menjadi yang terbaik di antara teman-teman sekitar 
lingkungan kerja; bekerja, bekerja, dan bekerja menikmati hidup sebagai tukang ukir. Saya terkadang berkumpul dengan teman-teman untuk kemajuan seni ukir Jepara ke depan, walaupun hanya diskusi ringan.

\subsection{Masa lalu sebagai tukang ukir kayu}

Awalnya saya malu bekerja sebagai tukang ukir kayu, tapi banyak dari orang lain yang ingin belajar banyak dari keahlian mengukir yang saya miliki. Akhirnya, saya menampung mereka untuk belajar ukir kayu di rumah, dengan sistem nyantrik. Awalnya, mereka yang belajar kebanyakan berasal dari sekitar Jepara, lalu berkembang sampai ke kota lain. Dari anak putus sekolah yang dititipkan, adapula dari keluarga tidak mampu. Bahkan ada yang datang dari Lampung, yang sengaja datang untuk mencari saya waktu dia melihat saya di koran tentang belajar mengukir gratis. Ada pula yang datang dari Jakarta, Kalimantan, dan kota lain.

Setelah mengalami kecelakaan, kegiatan belajar ukir kayu terganggu karena penghasilan saya menurun dratis. Tentunya saya menjadi tidak mampu untuk membiayai mereka dan hanya menampung sedikit orang dan akhirnya sekarang ditutup. Tapi ketika bersama teman-teman mendirikan LPK Ukir Sungging Mulyo, walaupun agak tersendat suatu saat saya yakin, akan ada uluran tangan dari pihak dermawan untuk mendukung melanjutkan kegiatan mulia ini.

Kebijakan dari semua pihak sangat diperlukan untuk memposisikan seni ukir Jepara sebagai warisan nenek moyang yang adiluhung dan perlu dipikirkan bagaimana regenerasi penerus ahli ukir sebagai pelestari seni ukir yang yang berkelanjutan. Menurut pemikiran saya, perlu pendekatan yang tidak hanya dari sudut pandang ekonomi saja, tapi perlu juga dari sudut pandang sosial politik dan kebijakan. Selama ini, apa yang saya lontarkan tentang ukiran Jepara dalam pertanyaan saya disikapi dari teman-teman Asmindo, APKJ atau yang lain, bahkan dari AMKRI (Asosiasi Mebel Kayu \& Rotan Indonesia) jawaban yang dilontarkan hanya dari sudut pandang ekonomi, jawaban mereka kebanyakan "Kalau pasarnya mebel ukiran ramai, maka ukiran akan berkembang tapi jika (pasar mebel ukir) sepi maka (pasar) ukiran akan menurun." 


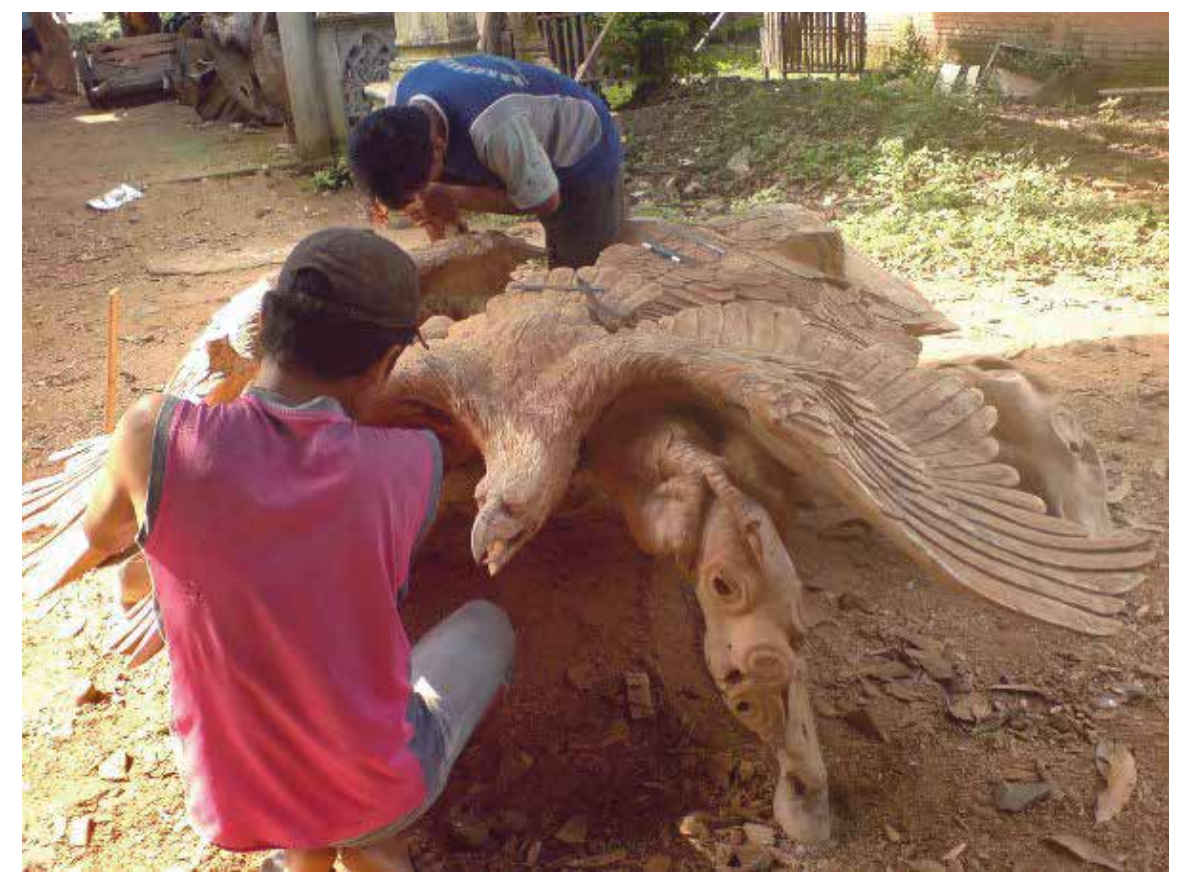

Gambar 4.1. Belajar membuat patung burung

Perlu kepedulian yang mendalam tentang regenerasi ukiran Jepara, karena akhir-akhir ini kondisi regenerasi penerus ukiran Jepara sangat berkurang dan sudah kurang menarik orang untuk belajar serta meniti karir sebagai tukang ukir. Jika keberadaan ukiran Jepara sudah kurang diminati, maka pasarnya pun akan jatuh. Maka untuk memulihkan kejayaannya perlu usaha dan biaya yang luar biasa besar. Daerah-daerah di luar Jepara memprogramkan pengembangan ukir kayu dan membuat sentral-sentral mebel ukir yang dikembangkan.

\subsubsection{Mendirikan perusahaan jasa ukir kayu}

UD Gajah Sungging Carving berdiri tahun 2006 menurut surat keterangan domisili, tapi baru terdaftar di perizinan Dinas Perindustrian pada tahun 2012 akhir. Dari UD Gajah Sungging Carving ini saya dapat menyejajarkan 


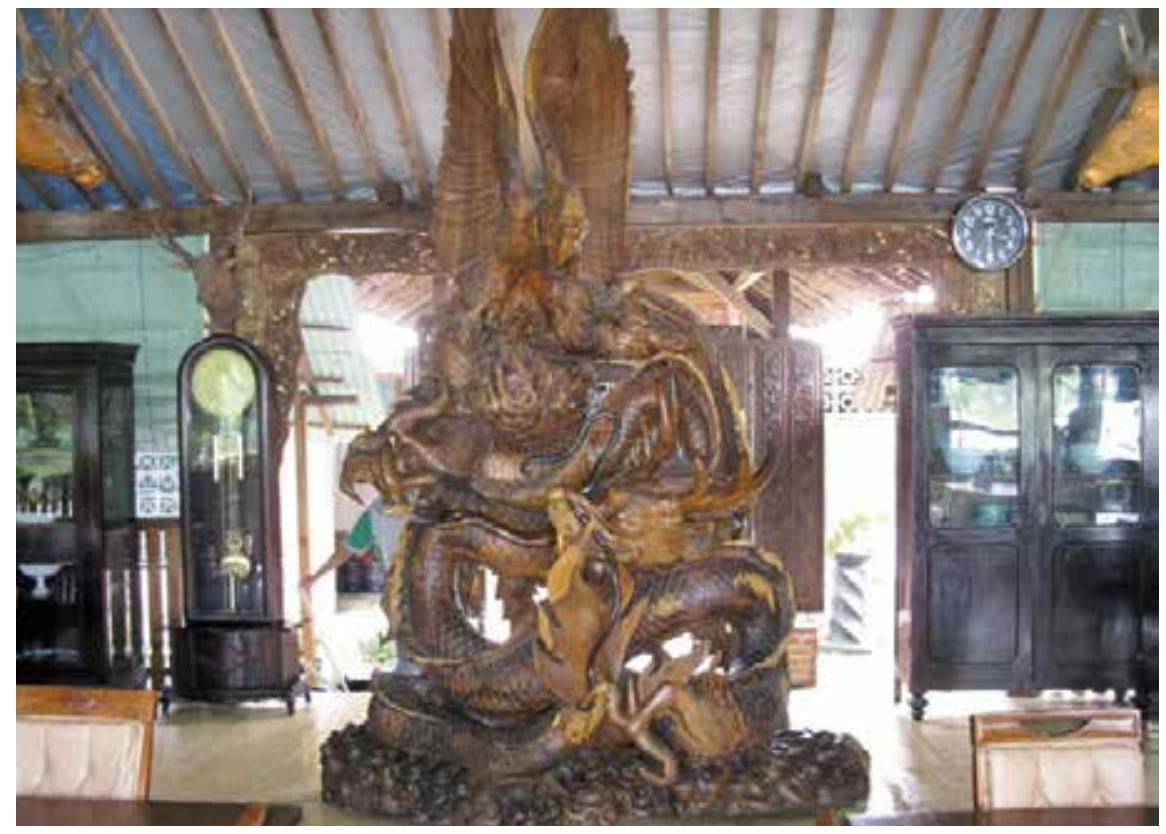

\section{Gambar 4.2. Patung ukir naga hasil karya saya yang pertama}

diri dengan penghasilan teman-teman setempat di Mulyoharjo yang sudah memiliki perusahaan. Namun dalam perkembangannya usaha ini mengalami ketertinggalan karena banyak faktor yang tidak dapat terpenuhi. Saya lalu bergabung ke Organisasi Centra Industri (OCI) yang merupakan organisasi perajin setempat dan memiliki 150 -an anggota. Sebagai anggota biasa tidak banyak pengaruh peran saya di lingkungan ini.

\subsubsection{Cara berpikir biasa}

Berjalan apa adanya, atau dalam bahasa Jawanya narimo ing pandum merupakan kalimat sangat populer dan seolah-olah menjadi panutan saya selama ini. Namun karena tuntutan dan tanggung jawab sebagai seorang pengukir, ada panggilan jiwa untuk melakukan perubahan yang lebih baik dan dapat mewariskan seni ukir Jepara ke generasi berikutnya. Sayangnya kemampuan saya terbatas, baik dari materi, ilmu, ataupun komunitas. 
Akhir 2009, saya mulai gencar mengikuti pendidikan seperti manajemen, teknologi informasi, manufaktur, maupun pembinaan profesi. Mulai dari program pelatihan daerah di Jepara, tingkat Jawa Tengah sampai program dari Kanada saya ikuti termasuk program APKJ yang bekerja sama dengan CIFOR dan ACIAR dengan tekun saya ikuti. Saya ingin agar kemampuan saya dalam keahlian mengukir, materi, dan komunitas mampu melakukan perubahan untuk ukiran Jepara di kemudian hari. Saya mulai mengerti bahwa sukses itu pengabdian, semakin besar kesuksesan yang diharapkan akan sebanding dengan besarnya pengabdian itu.

\subsection{Masa depan}

Hidup yang saya jalani beberapa tahun ke belakang di bidang ukir kayu biasa-biasa saja, meski terkadang ada angan, mimpi, rencana, dan pemikiranpemikiran ke depan dengan teman-teman seprofesi. Dalam kesendirian, saya sering membaca materi-materi pelatihan, salah satu yang menarik adalah teori AMT (Achievement Management Training), yang diadakan pada awal 2010. Dari materi itu saya dapat memetakan mimpi saya menjadi beberapa kategori (a) Mimpi/khayalan bersahabat; (b) Mimpi/khayalan berkuasa; (c) Mimpi/khayalan berprestasi dan (d) Mimpi/khayalan ragu-ragu. Keempat kategori mimpi ini saya gunakan sebagai acuan langkah untuk menuju keadaan yang lebih baik. Tapi hal tersebut baru saya praktikkan dalam ucapan dan tulisan yang berulang dan terus-menerus supaya otak saya dapat terbangun dan termotivasi dari kata-kata serta tulisan itu. Kegiatan ini murah-meriah tapi dapat mengarahkan saya untuk melakukan kegiatan positif dan lebih baik. Lebih lanjut mimpi tersebut saya maknai sbb:

- Mimpi/khayalan bersahabat: Pada kategori ini membiasakan mengucap dan menulis kata-kata seperti berjalan-jalan, duduk-duduk, mengenang, menikmati, merenung, santai, tamasya, pesta, rekreasi, tidur, menonton, dll.

- Mimpi/khayalan berkuasa: Pada kategori ini membiasakan mengucap dan menulis kata-kata seperti melakukan, memecahkan masalah, memerintahkan, membicarakan, mendiskusikan, menasihati, memeriksa, mengatasi, membahas, meneliti, dll. 
- Mimpi/khayalan berprestasi: Pada kategori ini membiasakan mengucap dan menulis kata-kata seperti sukses, bonafid, juara, prestasi, membangun, memperluas, memajukan, mendirikan, lebih baik, meningkatkan, mengembangkan, menciptakan, menemukan, dll.

- Mimpi/khayalan ragu-ragu: Pada kategori ini kurang banyak saya perhatikan.

Dari keempat kategori khayalan tersebut, kategori khayalan berkuasa dan khayalan berprestasi yang saya gunakan dalam merintis pengembangan profit, jaringan, dan berorganisasi/mendapatkan posisi. Kedua kategori ini saya gabung dengan istilah berpikir prestasi. Materi dan teori itu, membuat saya lebih mudah mendapatkan apa yang saya impikan secara bertahap. Dengan teori ini pula saya memiliki keberanian dan keyakinan kuat bahwa mimpi dapat diwujudkan dan berperan menjadi aktor perubahan. Untuk itu saya petakan dengan skema kebutuhan yang harus saya rencanakan untuk memenuhinya supaya dalam pelaksanaannya menjadi mudah, fokus, efisien, dan terarah (Gambar 4.3).

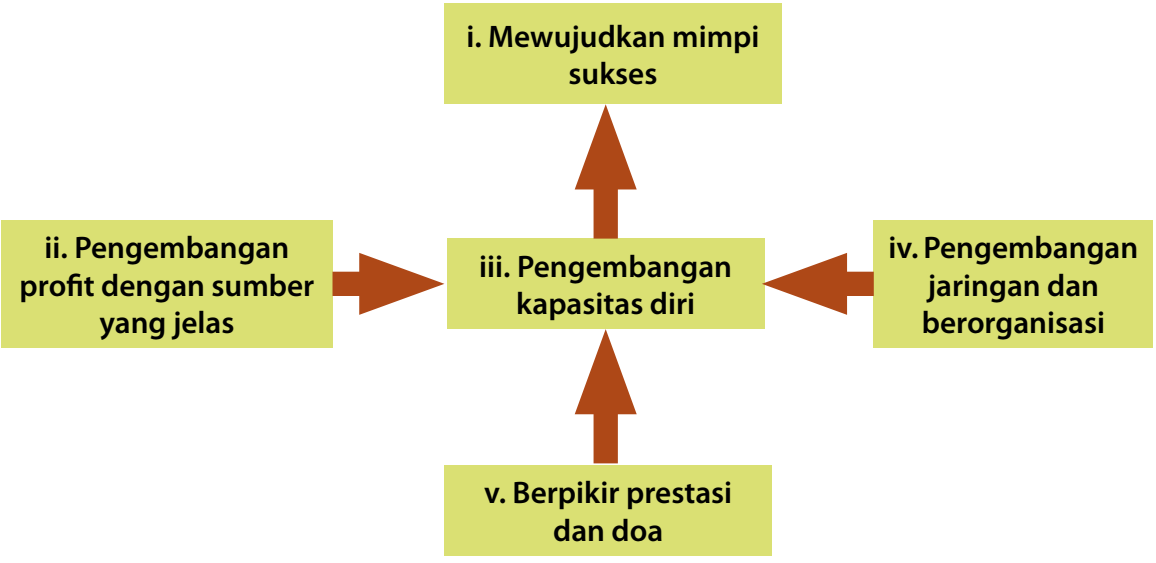

Gambar 4.3. Skema empat kebutuhan untuk menggapai mimpi 


\subsubsection{Mewujudkan mimpi sukses}

Dari skema kebutuhan di atas, tersirat dua faktor yang memengaruhi saya yaitu faktor internal dan faktor eksternal. Terlihat faktor eksternal hanya pada kebutuhan di bagian iv. pengembangan jaringan dan berorganisasi, berarti kesuksesan saya untuk menggapai cita-cita dan mimpi $80 \%$ bergantung pada kemampuan untuk memenuhi kebutuhan internal yaitu pada bagian i, ii, iii, dan v.

Faktor internal mewajibkan saya untuk mempunyai niat yang kuat, tujuan dan visi misi yang jelas, mempunyai kemampuan yang dibutuhkan, dan tak kalah pentingnya tentu disertai pengorbanan sesuai kemampuan dengan doa yang tekun.

\section{Pengembangan profit dengan sumber yang jelas}

Untuk mengembangkan profit dibutuhkan mobilitas yang tinggi dan tentu perlu biaya dan materi kuat. Untuk itu saya membangun perusahaan Gajah Sungging Carving (GSC) untuk menguatkan branding saya sebagai seniman ukir kayu dan Indonesia Furniture Center (IFC) untuk menguatkan posisi dalam berorganisasi dan mempunyai tingkat ekonomi dalam kebersamaan besar untuk menjadi perusahaan menengah besar. GSC adalah perusahaan UKM yang bergerak di bidang jasa ukir kayu, memproduksi ukiran mebel patung dan penjualan.

CV IFC merupakan payung kegiatan dari tiga UKM, yaitu Gajah Sungging Carving, Mebel Jati Jepara, dan Multi Usaha Raya. Tujuan usahanya adalah untuk meningkatkan kapasitas dan kelasnya supaya mampu menjadi perusahaan menengah dan besar dengan harapan mampu bersaing di pasar lokal dan ekspor. Selain itu harapan kami adalah agar mampu berkiprah mengembangkan industri mebel ke belahan dunia yang lebih luas, terutama di benua Amerika, Eropa dan Australia. Menjadi UKM menurut saya, masih melekat anggapan sebagai pengusaha kecil yang sarat dengan ketidakmampuan dan banyak masalah yang tidak dapat diselesaikan sendiri dan terkesan selalu merepotkan pemerintah dan lembaga lainnya. 


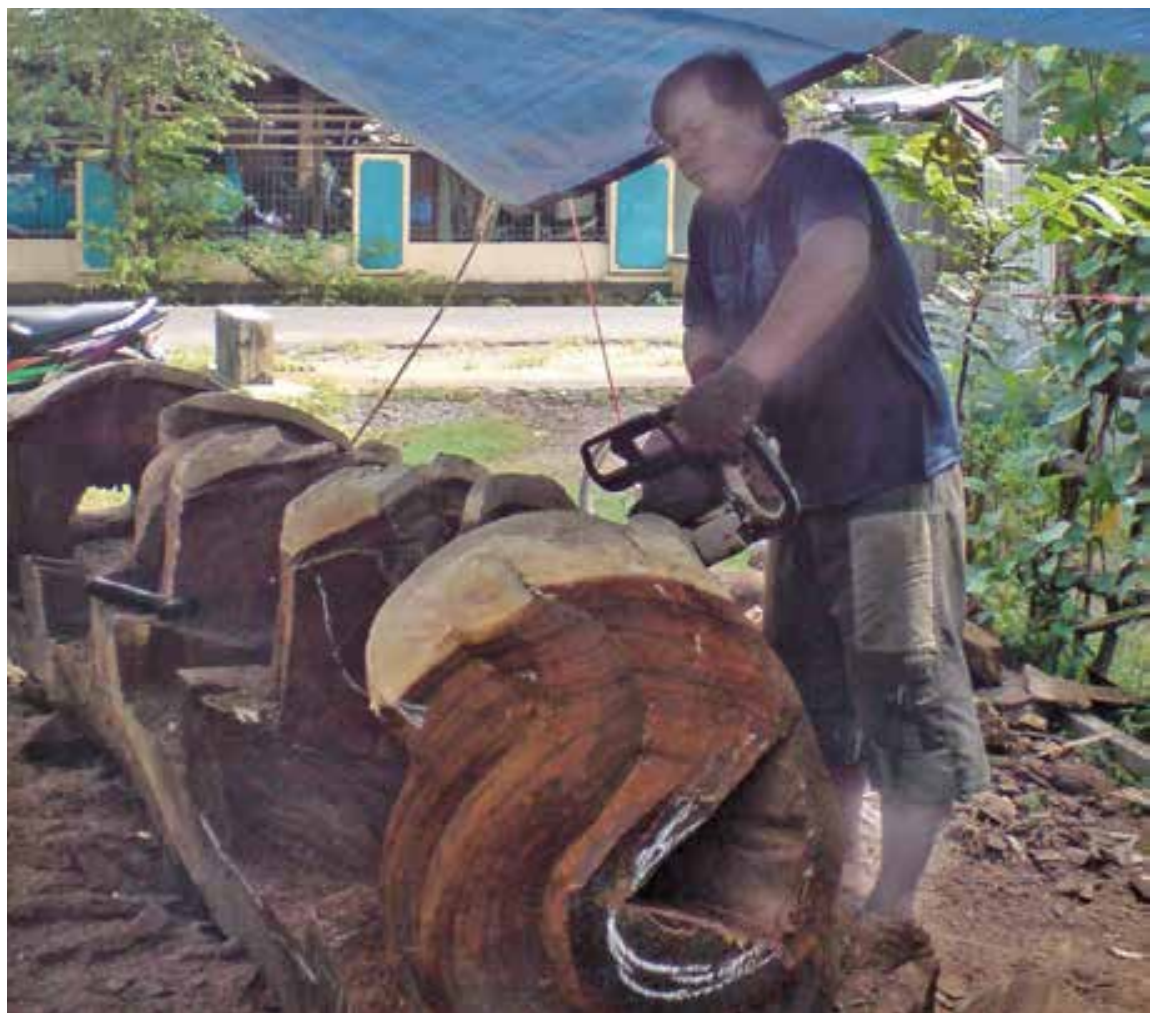

Gambar 4.4. Proses mengukir patung naga dengan bantuan gergaji mesin

Untuk membangun penguatan dan pengembangan profit dengan sumber yang jelas perlu perencanaan yang jelas serta target dan kapasitas yang terukur. Untuk itu, saya berfokus di GSC dan IFC untuk membangun profit dan penghasilan serta penyaluran bakat sebagai artisan ukir kayu. GSC berperan sebagai tempat pengembangan branding sebagai artisan ukir kayu dan IFC sebagai tempat pengembangan usaha besar bersama komunitas permebelan. Adapun rencana mewujudkan tujuan dalam 10 tahun ke depan dapat saya uraikan sebagai berikut. 


\subsubsection{Perencanaan mewujudkan impian dan cita-cita}

Untuk 10 tahun ke depan ada dua rencana untuk mewujudkan cita-cita saya yaitu: Pengembangan branding sebagai artisan wood carving. Media dan tempatnya adalah di GSC dan pengembangan usaha pada perusahaan IFC yang sekaligus membangun pengembangan jaringan pasar dan berkomunitas.

Selama dua tahun terahir ini (awal 2010 sampai 2012), saya berupaya keras dalam pembekalan untuk meraih keinginan saya, baik pembekalan di pembangunan kapasitas, kapasitas berorganisasi dan pengembangan pasar, serta kapasitas pengembangan penghasilan. Namun upaya ini terasa masih jauh untuk mencapainya dengan bekal yang saya miliki. Ada dua faktor yang menjadi kendala: faktor internal kadang sudah tercapai tapi faktor eksternalnya belum terpenuhi.

Adanya perusahaan GSC dan IFC diharapkan dapat memenuhi kebutuhan faktor internal dan faktor eksternal yang diperlukan dalam melakukan usaha secara maksimal. Namun kemudian, muncul masalah baru yaitu kapasitas manajerial saya yang masih kurang memadai. Untuk itu, dalam mewujudkan dan meningkatkan kemampuan manajerial, saya bekerja sama dengan Mr. Pitt dari GIZ dalam programnya dua tahun ke depan, yaitu bersedia menjadi konsultan manajemen strategi dan perencanaan ke depan, khususnya tentang konsep pasar serta konsep manajemen.

Manajemen konsep, manajemen strategi pengembangan pasar, strategi konsep pengembangan branding perusahaan dan personal serta konsep manajemen perusahaan yang diajarkan Mr. Pitt diharapkan dapat melengkapi kekurangan serta dapat mengatasi pemenuhan kapasitas manajerial saya. Begitu juga dengan kegiatan program ACIAR, CIFOR, GIZ, TFO Kanada, PPEI, pemerintah daerah dan pusat serta lainnya, ke depannya dengan tekun akan saya ikuti untuk pemenuhan kapasitas manajerial.

\subsubsection{Pemetaan antara kebutuhan dan masalah}

Pemenuhan kebutuhan saja tidak cukup. Dalam pemenuhannya perlu dipetakan supaya seimbang, efisien, tepat sasaran, dan terukur. Tak lupa 


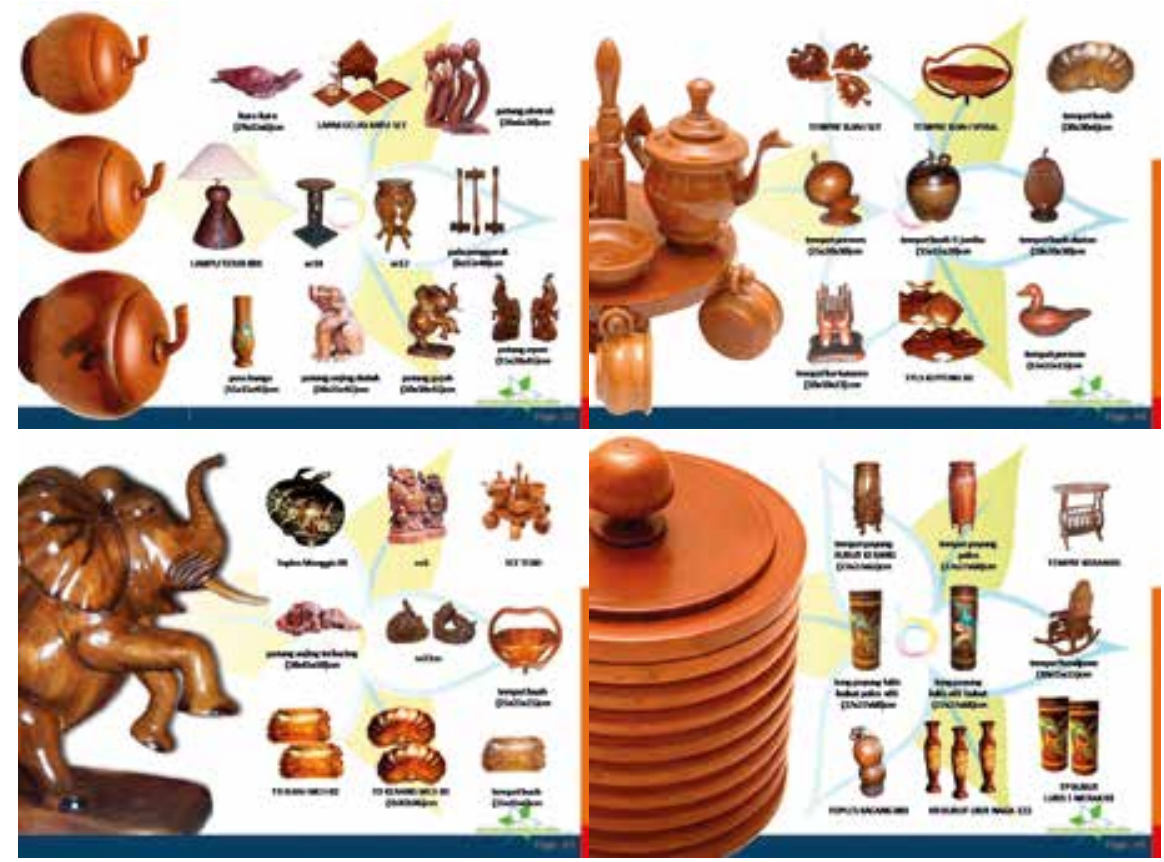

Gambar 4.5. Katalog Indonesia Furniture Center (IFC)

selalu berpikir prestasi dan doa. Keadaan saya yang serba pas-pasan membuat saya berpikir pas-pasan juga. Untuk itu, walau hanya untuk memenuhi kebutuhan kecil, harus dipetakan pemenuhannya. Karena sumber masalah yang saya alami biasanya diawali dengan menganggap mudah kebutuhan kecil yang dipandang mudah untuk dipenuhi, maka melalui peta kebutuhan, saya akan dapat menemukan masalah lebih awal. Dengan begitu masalah dapat saya selesaikan tahap demi tahap supaya terasa ringan.

\subsubsection{Pengembangan kapasitas diri}

Akhir 2010, saya bergabung di APKJ sebagai anggota dan langsung menjadi pengurus bidang pengembangan SDM. Bersama teman-teman pengurus APKJ kami bahu-membahu memperjuangkan aspirasi UKM perajin kayu Jepara. Dalam kegiatan internasional, saya mengikuti konferensi komunitas 
kayu dan lembaga lainya seperti IWCS (International Wood Culture Society) di Bangalore, India, tentang pemanfaatan fungsi kayu secara bijaksana dan lestari yang memengaruhi budaya dan ekonomi dunia. Selain itu, saya melakukan kegiatan dan pelatihan bersama Disperindag Jepara maupun Jawa Tengah, serta mengembangkan jaringan dan berorganisasi di tingkat lokal, kabupaten dan provinsi.

Menyadari keterbatasan saya, baik dari kapasitas diri dan kemampuan sebagai UKM, saya harus menggali potensi yang ada pada diri, dengan berpedoman pada:

\section{Masalah saya jadikan potensi,}

tantangan dan tantangan saya jadikan ujian, keterbatasan dan ketidakmampuan saya jadikan modal, serta kebutuhan yang tak terpenuhi saya jadikan solusi.

Untuk menggapai kesuksesan tidak hanya cita-cita yang besar, tekad, dan keinginan yang besar serta keyakinan yang kuat, tapi menyadari saya termasuk UKM yang di bawah standar dengan modal terbatas, maka saya perlu yang lain, yaitu berpikir prestasi.

CIFOR bersama APKJ dan program FVC-nya memberikan kesempatan saya bergabung di dalamnya dan dari sini saya memperhatikan satu persatu mereka, karena di sini pula saya merasa paling bodoh. Namun saya merasa seperti terus ditantang oleh perkataan kakek saya: "Kalau ingin pinter kumpullah dengan mereka yang pinter dan jika ingin sukses kumpullah dengan mereka yang sukses. "Dari situ saya mulai belajar seperti mereka. Bahkan jika Pak Herry Purnomo dari CIFOR datang ke Jepara, saya diam-diam sangat memperhatikan cara bicaranya, cara memberi solusi, kebijakannya dan sistem manajerialnya serta cara berpikirnya; yang akhirnya saya tiru. Kesempatan untuk bertemu dengan orang hebat dalam bentuk seminar atau pelatihan saya tiru juga. Akhirnya, cara bicara, cara berpikir dan yang lainnya mulai bisa saya imbangi. Dari sinilah saya menerapkan cara berpikir prestasi. Doa tak kalah penting, dengan berpikir prestasi sebagai pembangkit roh untuk 
sukses dengan tata cara yang benar. Keyakinan yang kuat dan besar adalah salah satu modal untuk mewujudkan kesuksesan.

\subsection{Program dan pembiayaan}

Pada awal Januari 2013, saya mengalami kesulitan di bidang pembiayaan, bukannya salah prosedur tapi memang sudah saya prakirakan sejak awal. Saya sudah banyak menanyakan tentang sistem pembiayaan beberapa bank tentang UKM. Dalam kajian saya tentang UKM bidang usaha kayu di Jepara, ada dua kategori UKM yang bermasalah dalam usahanya, yaitu:

- UKM yang memang bermasalah karena usahanya bermasalah

- UKM yang bermasalah bukan karena usahanya bermasalah, tapi karena dalam posisi fase naik kelas.

UKM yang dalam posisi fase naik kelas ini rawan gagal dalam melakukan kegiatan usahanya. Hal ini menarik untuk dibahas karena UKM ini nantinya akan dapat lebih mandiri dan dapat membantu serta memberikan inspirasi dan motivasi untuk maju dan sukses bagi UKM setingkat di bawahnya. Saya sendiri dalam mendirikan CV IFC adalah untuk naik kelas ke bidang usaha pemasaran atau perusahaan pemasaran, yang awalnya UD GSC hanya sebagai perusahaan jasa ukiran kayu dan produksi saja.

Modal dan investasi yang saya kucurkan di CV IFC jika diberikan pada UD GSC sudah lebih dari cukup untuk mengembangkannya. Melalui CV IFC saya tidak sekedar mengembangkan usaha yang asalnya kecil menjadi lebih besar, tetapi supaya perusahaan mempunyai kapasitas dan jangkauan yang lebih luas. Tujuannya adalah mengembangkan pasar karena teman-teman UKM di Jepara mengalami kesulitan dalam memasarkan produksinya.

Pihak perbankan rupanya tidak mau terlalu jauh membahas tentang masalah UKM, asal pinjamannya dapat kembali tanpa masalah. Padahal seandainya pihak perbankan sudi menggarap masalah proses naik kelas perusahaan yang saya bangun di CV IFC ini, nilai manfaatnya akan sangat besar. Bank tidak hanya sekedar memberikan kredit tapi juga menambah satu perusahaan yang 
lebih mandiri dan dapat membantu UKM di bawahnya dalam pemasaran serta dapat memotivasi untuk menirunya.

Namun kesulitan yang saya hadapi itu saya anggap saja jeda untuk evaluasi dan istirahat sejenak dan saya programkan supaya pada April 2013 sudah teratasi. Program pendampingan dari Disperindag Jawa Tengah, PPEI, dan LPEI sebenarnya lebih awal sudah saya bangun tapi prosesnya lambat karena masih dalam kondisi tarik-ulur dan saya tergolong orang baru di sini. Setidaknya ke depan hubungan akan terjalin lebih baik dan saling menguntungkan, sehingga CV IFC dapat mengembangkan pasar dan mengatasi masalah internal dan eksternal perusahaan ketika pembangunan fisik dirasa sudah cukup.

Di samping itu, program penguatan pasar dengan DJPEN sudah terbangun dengan baik, yang diawali dengan mengikuti pameran di IFFINA 2013 di Jakarta pada tanggal 11-14 Maret 2013. Namun untuk mendapatkan fasilitas penguatan pasar, yaitu mengikuti pameran itu masih perlu pengkondisian karena yang membutuhkan banyak sekali sedangkan fasilitas stand pameran dari DJPEN hanya 15 stand untuk seluruh UKM binaannya di Indonesia. Tim yang saya siapkan untuk mendapatkan fasilitas pameran itu tidak sia-sia karena setidaknya satu stand pameran sudah diraih.

Saya berangkat ke Tanzania tanggal 16 Maret 2013 untuk mengikuti International Competition and Attraction Wood Carving 2013 di Tanzania, Afrika, dan sebagai salah satu delegasi yang mewakili Indonesia dalam satu paket acara itu. Di acara yang sama tahun 2012 kawasan kerja sama dagang CAFTA China-ASEAN di Nang Ning, China, saya mendapatkan kemenangan sebagai peserta terbaik desain ukiran kayu dan mendapatkan gelar master carving versi pemerintah China bersama dua peserta lain dari China. Saya memiliki tujuan lain ketika mengikuti acara ini, yaitu bagaimana bisa meningkatkan kemampuan saya sebagai pengusaha bidang kayu dan sekaligus sebagai pelaku yang memiliki keahlian bidang ukiran kayu yang mampu mengembangkan penggabungan keahlian teknik mengukir dan nilai entertainment. Maksudnya adalah menciptakan kesempatan untuk mendapatkan uang dari bidang kayu tidak hanya lewat nilai jual dari nilai 


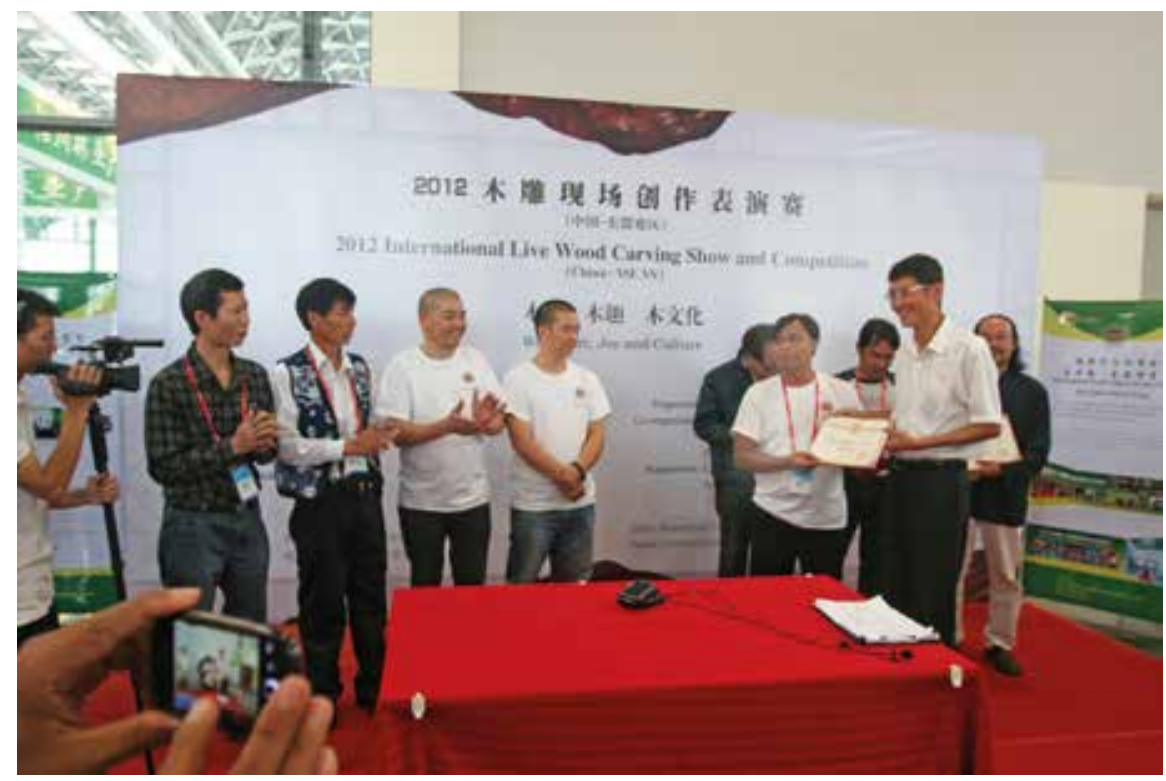

Gambar 4.6. Menjadi pemenang terbaik desain ukir pada China-ASEAN International Competition and Atraction Wood Carving 2012 di Nan Ning, China

seni dan produksinya tapi juga dari nilai pertunjukan yang dikemas untuk memberikan semacam hiburan dan daya tarik untuk lebih mencintai kayu supaya perlakuan pemanfaatan kayu lebih bijaksana dan berkelanjutan.

Di samping itu, nilai entertainment pun diangkat sebagai nilai tambah karena yang dijual adalah pertunjukan mengukirnya. Eksplorasi penggunaan kayu dan pohon yang ditebang dapat sangat ditekan sedangkan nilai tambah yang didapat sangat tinggi. Misalnya, dalam acara di China tanggal 15-18 November 2012, atraksi yang saya tampilkan hanya memerlukan dua balok kayu ukuran diameter $50 \mathrm{~cm}$ panjang $2 \mathrm{~m}$ dengan tenaga saya sendiri dan beberapa kru. Kru teknis, tenaga promosi dan tim pengatur acara dapat menghasilkan uang yang berjumlah sama dengan produksi yang dilakukan di pabrik yang memerlukan ratusan kubik kayu, ratusan tenaga, waktu yang lebih lama, dan alat-alat dengan investasi yang mahal serta sumber energi 
yang banyak. Ini hanya dari sudut pandang pemanfaatan kayu dan nilai efisiensi penggunaan kayu saja.

Jelasnya, ada dua manfaat yang bisa saya petik dari acara internasional itu. Pertama, kami merasakan manfaat misi saya mengembangkan kapasitas dan pengembangan jaringan yang saya susun untuk menggapai tekad saya. Ke dua, saya dan teman-teman di tim CV IFC berkesempatan untuk menjadikan perusahaan ini menjadi perusahaan pemasaran mebel dan produk lain berskala internasional. Kedua manfaat ini yang nantinya dapat membantu kesulitan pemasaran yang selama ini dialami teman-teman para perajin kayu Jepara di sekitar lingkungan saya.

Di Tanzania juga ada kesepakatan kerja dengan wakil delegasi Malaysia yang saya bangun mulai dari acara di China. Semoga ada hasil dari upaya saya mengikuti acara internasional ini karena banyak hal yang saya harapkan dari sana. Jelasnya, saya sudah menjadi bagian dari komunitas dan peserta tetap dalam acara dan gerakan mengembangkan budaya kayu yang memengaruhi masyarakat dunia dari sudut pandang ekonomi, budaya, politik, dan sosial. Di sini pula saya mendapatkan kesempatan untuk memberikan sumbangsih dari keahlian saya dalam misinya untuk memanfaatkan kayu dengan bijaksana.

\subsection{Kesimpulan dan saran}

\section{Kesimpulan}

- Keterbatasan, ketidakmampuan, kurang pengetahuan, dan kapasitas berpikir biasa bukanlah halangan bagi saya untuk berkembang seperti mereka yang sudah sukses, baik yang dicapai sendiri maupun warisan.

- Kemauan keras, keyakinan, dan berpikir untuk berprestasi besar serta doa yang benar akan membuat tidak ada hal yang mustahil. Keberadaan pemerintah, perbankan, program lembaga dan lainnya hanyalah 20\% dalam memengaruhi sukses kita; kesuksesan kita adalah $80 \%$ tergantung pada diri kita sendiri. 
- Motivasi diri kita dalam mengembangkan kapasitas, profil, jaringan, dan berkomunitas serta berpikir prestasi dan doa akan sebanding dengan kesuksesan yang ingin kita raih.

- Sebagai UKM tidak salah kita merapat ke pemerintah atau lembaga lainnya untuk mendapatkan kemudahan dan fasilitas, tapi jika sudah besar perhatian kepada yang kecil tetap jangan dilupakan untuk memberi sedikit bantuan atau contoh agar mereka juga bisa menjadi besar.

- Upaya untuk menjadi besar tidak dapat dilakukan sendiri tapi dengan kerja tim yang kompak bersatu dan saling mendukung. Berpikir besar dan berani mewujudkannya adalah salah satu proses menuju sukses.

- Untuk mendapatkan kesuksesan dan mimpi yang kita inginkan, tidak cukup hanya kerja keras siang dan malam sampai berdarah-darah, tapi perlu putar otak dan harus terampil bekerja sama dalam tim yang solid.

\section{Saran}

Tanpa bermaksud menggurui saya membagikan cerita nyata yang saya alami dalam keseharian, upaya yang saya lakukan untuk lebih maju bukannya tak beralasan. Banyak fasilitas yang saya dapatkan dari pemerintah dan lembaga terkait seperti CIFOR, APKJ, dan lembaga lain. Karena itu kesuksesan yang saya peroleh dapat saya ceritakan, saya tularkan, saya sumbangkan, dan saya programkan bagi mereka yang belum mendapatkan fasilitas ini. Ada panggilan yang kuat dan rasa malu pada yang lain karena saya selalu mendapatkan fasilitas tapi belum bisa seperti yang diharapkan. Karena itu saran saya untuk teman-teman pengurus dan anggota APKJ:

\section{Anjuran}

- Sekali-kali berspekulasilah walau babak-belur, remuk tanpa daya dan rupa. Karena melaluinya kamu merasakan dan mengalami apa yang belum pernah kamu pikirkan.

- Belajarlah menghargai supaya kelak di kemudian hari kamu akan dihargai dan menjadi besar.

- Jadilah pembawa perubahan walaupun kecil dan sesaat, karena setelahnya kamu akan dikenang sebagai pahlawan. 


\section{Larangan}

- Jangan takut salah karena kamu ini kecil, jika terjadi kesalahan pun tidak akan membawa pengaruh yang berarti, tapi jika benar kamu akan menjadi lebih besar dan sukses.

- Carilah peluang karena peluang bukanlah pemberian tapi sebuah perjuangan. Di APKJ serasa semua sudah ada, hanya cara mendapatkan peluang yang belum.

- Berpikir prestasi supaya seperti orang yang telah berprestasi sebagai modal termurah untuk menggapai sukses. 


\section{Bab 5.}

Tukang ukir merantau, mengembangkan usaha, dan berorganisasi

Oleh: M. Suryadi

\subsection{Masa kecil dan pendidikan}

Nama saya Muhammad Suryadi, lahir di Jepara, 20 Juli 1966, di sebuah desa kecil yaitu Mulyoharjo, Kecamatan Jepara, Kabupaten Jepara, Jawa Tengah. Sehari-hari akrab dengan panggilan "Moh" meski ada juga yang memanggil "Seger". Saya adalah anak ke tiga dari lima bersaudara.

Waktu itu orang tua saya bekerja sebagai pegawai rendahan di salah satu kantor pemerintahan kabupaten di Kota Jepara dengan gaji bulanan sangat kecil. Memang penghasilan orang tua saya sangat pas-pasan dan jauh berbeda jika dibandingkan dengan penghasilan tukang kayu atau tukang ukir saat itu, tetapi semuanya tetap kami syukuri.

Pada tahun 1972, saya masuk sekolah kecil atau dikenal dengan sekolah taman kanak-kanak. Satu tahun kemudian saya masuk sekolah dasar satusatunya yang ada di Desa Mulyoharjo. Pada waktu itu, dinding bangunan 
sekolah masih terbuat dari anyaman bambu dan banyak lubang-lubang besar. Di sekolah, saya bukan termasuk anak yang cerdas dan pandai, tetapi juga tidak terlalu bodoh. Setiap hari saya berangkat ke sekolah hanya dengan sarapan seadanya, bahkan juga terkadang tidak sarapan. Orang tua hanya memberi uang saku sebesar Rp10 yang hanya cukup untuk beli bakwan dan mendoan. Meski begitu tetap saya syukuri. Ketika pulang sekolah saya hanya makan nasi campur jagung dan lauk juga seadanya. Kalau makan di rumah kurang kenyang, biasanya saya ke rumah nenek untuk minta makan lagi supaya lebih kenyang. Kadang-kadang pulang sekolah saya tidak langsung ke rumah tapi justru ke rumah nenek yang tidak jauh dari rumah orang tua saya untuk minta makan dan dengan harapan diberi uang saku untuk besoknya.

Suatu hari, saya bangun pagi-pagi dengan semangat mau ke sekolah. Biasanya saya jalan kaki, tetapi pagi itu saya dipinjami sepeda onthel butut satu-satunya milik orang tua yang biasa dipakai untuk perjalanan ke kantor. Sepeda itu menggunakan kunci keamanan jarum putar seperti kunci gembok biasa yang umum dipasang di sepeda, dengan kode angka rahasia jarum jam yang sudah saya ketahui caranya, namun saya tidak mau ambil risiko jika dibawa ke sekolah. Tak lama kemudian, saya ke sekolah naik sepeda onthel dengan rasa bangganya dan juga sengaja tidak dikunci. Tiba-tiba teman saya datang untuk mencoba kuncinya yang antik itu. Padahal saya sudah peringatkan supaya jangan dikunci, ternyata malah dikunci. Saat itu hanya terpikir bagaimana membuka kuncinya kembali. Saya mencoba untuk membukanya sampai beberapa waktu lamanya, namun hingga pulang sekolah belum berhasil juga. Hampir dua jam lamanya saya otak-atik kembali kuncinya tapi tetap tidak bisa dan akhirnya sepeda onthel itu saya pikul sampai di rumah dengan dibantu teman-teman. Setelah itu, saya berjanji tidak mau membawa sepeda lagi karena kapok.

Untuk mengisi waktu luang sekolah, saya ikut menggembala kambing kakek. Kadang saya juga menggembalakannya sendiri sampai kelas IV SD. Kemudian, saya mulai belajar mengukir pada Pak Dirdjo Kemad yang tempatnya tidak jauh dari rumah. Ketika itu Pak Dirdjo dipercaya oleh beberapa juragan dari kota untuk mengerjakan pekerjaan mengukir. Selama kurang lebih tiga tahun saya bekerja dengan penuh ketekunan dan 
kedisiplinan, hingga mampu dan dianggap lulus oleh sang guru Dirdjo. Kemudian saya diperbolehkan untuk memborong sendiri pekerjaan mengukir yang diterima oleh Pak Dirdjo. Maka setiap pulang sekolah, saya lalu mengukir agar mendapatkan upah dari sang juragan. Saya sangat senang bisa mencari uang sendiri walaupun jumlahnya tidak seberapa, tapi cukuplah untuk memenuhi kebutuhan sendiri. Namun kadang saya tinggalkan pekerjaan mengukir untuk bemain dengan teman-teman sebaya sampai tidak ingat waktu. Ketika itu, saya berpikir bahwa membagi waktu sangatlah penting, kapan untuk sekolah, untuk menyelesaikan pekerjaan serta waktu untuk bermain. Belajar membagi waktu saya terapkan cukup lama, hingga saya lulus SMP tahun 1983, walaupun belum sempurna. Setelah lulus SMP dengan nilai pas-pasan, saya memberanikan diri untuk mendaftar di SMAN 1 Jepara, tetapi hasilnya tidak cukup baik karena tidak diterima. Saya tidak patah semangat untuk terus belajar.

Lalu saya berinisiatif untuk masuk sekolah yang sifatnya adalah pendidikan kejuruan yaitu kursus elektronika dan kelistrikan yang nonformal selama kurang lebih tiga tahun hingga selesai. Selain itu, saya masih belajar di rumah dengan menambah pengetahuan dan ilmu-ilmu lainnya, khususnya elektronika dan listrik mengingat perkembangannya sangatlah pesat. Jadi saya belajar secara otodidak dengan membeli buku-buku terbaru untuk menambah ilmu dan wawasan yang lebih luas. Ilmu yang dipelajari saya terapkan di lapangan dengan membuka servis elektronika di rumah dan ternyata mendapat respon yang baik dan banyak tetangga yang datang. Alatalat elektronika yang diservis seperti: tv, radio, kulkas, tape, amplifier, dan alat-alat lainnya yang berhubungan dengan elektro dan listrik. Banyak pula tetangga yang datang minta tolong untuk membetulkan peralatan listriknya dengan berbagai masalah. Bahkan ada juga yang minta bantuan untuk menambah jaringan listrik di rumahnya atau di tempat usahanya. Listrik PLN baru masuk Desa Mulyoharjo pada tahun 1986, sehingga masyarakat bisa menikmati terangnya lampu listrik dan alat elektronik lainnya.

Di sela-sela kekosongan dan kesibukan di bidang elektro dan kelistrikan, saya masih mengukir dan juga bermain sepak bola dengan teman-teman pada sore harinya. Pekerjaan mengukir tidak sulit didapatkan karena di daerah saya ada 
yang membuat mebel seperti almari, bufet, dan ornamen lainnya. Karena tidak banyak perajin mebel di sekitar tempat saya, kadang-kadang saya juga mencari pekerjaan mengukir di tempat lain. Keberlangsungan perajin mebel di tempat saya kurang menjanjikan harapan untuk seorang pengukir, jadi saya mencari pekerjaan mengukir yang lebih baik di tempat lain. Kemudian saya tiap hari bekerja di tempat lain, selama kurang lebih dua tahun.

\subsection{Merantau ke Jakarta dan Tangerang}

Suatu ketika saya ditawari oleh teman untuk diajak ke Jakarta pada tahun 1987, karena di sana ada perusahaan yang membutuhkan tenaga ukir. Saya langsung setuju dan pada hari keberangkatan hatiku sangat senang karena ingin cepat-cepat melihat kota metropolitan yang katanya sangat megah dan indah. Sesampainya di Jakarta, saya terkagum-kagum melihat bangunan dan gedung pencakar langit yang tinggi. Di sana saya bekerja mengukir dan memulai kehidupan baru di rantau dan harus menyesuaikan dengan lingkungan sekitar. Setelah beberapa minggu mengukir dengan penuh semangat, ternyata pekerjaan mengukir ini tidak berlangsung lama, hanya sekitar dua bulan saja. Saya kembali pulang dari rantau dengan membawa sedikit rejeki dan pengalaman berharga yang tak terlupakan. Saya harus dapat menyesuaikan lagi dengan pergaulan teman-teman yang saya tinggalkan selama di rantau.

Saya memulai lagi kehidupan dengan mengukir di kampung halaman. Memang pekerjaan mengukir, elektro, dan listrik sudah menjadi semacam pekerjaan yang mengikat dalam diri saya. Lalu, beberapa tahun kemudian, saya mendapat tawaran mengukir lagi di Kota Tangerang yang juga saya sanggupi dengan sepenuh hati karena ingin mencari pengalaman dan rejeki di rantau. Sesampainya di Tangerang, menurut saya suasananya tidak begitu jauh dengan Jakarta. Kemudian saya diajak memasuki gudang yang sangat besar dan luas milik sebuah perusahaan asing, ternyata di dalamnya sudah banyak pekerja pengukirnya, dengan cara borongan ataupun harian. Namun saya tidak patah semangat dan tetap dengan pendirian yang kokoh untuk bekerja di rantau. 
Esok harinya, saya langsung bekerja dengan penuh semangat dengan diselimuti perasaan gembira karena bisa mengerjakan pekerjaan yang diberikan. Kemampuan mengukir yang saya miliki membuat saya merasa percaya diri di manapun bekerja. Tak terasa waktu telah berlalu hingga tiba sore hari untuk istirahat. Setelah istirahat sejenak, saya kembali lagi untuk bekerja lembur bersama teman-teman lainnya sampai larut malam dan baru beristirahat untuk tidur. Esok harinya bekerja lagi seperti biasanya, memang demikian kalau hidup dan bekerja di rantau haruslah giat dan ini sudah menjadi prinsip saya. Bekerja di Tangerang sebetulnya lumayan baik namun pekerjaan ini tidak lebih dari satu bulan sudah selesai. Maklumlah, tenaga kerjanya banyak sekali. Lalu saya pulang kampung dan menata kembali pergaulan dengan lingkungan khususnya teman-teman di rumah. Kehidupan tetap berjalan dan harus terus bekerja demi mencapai cita-cita untuk masa depan.

Kira-kira awal tahun 1992, suatu hari tiba-tiba orang tua saya berkata "Opo kowe ora kepingin kawin, konco-koncomu wes podo kawin lan duwe anak (Apa kamu tidak ingin menikah, teman-temanmu semua sudah menikah dan mempunyai anak)?" Lalu saya menjawab tanpa sengaja "Nggeh mangkeh tahun 1993 (ya, nanti tahun 1993). Padahal saat itu saya belum ada persiapan apa-apa dan juga belum memiliki calon. Waktu telah berjalan namun saya masih pasif dan belum menanggapinya dengan serius meski ini saya anggap sebagai janji kepada orang tua. Pada suatu malam, saya bermimpi terbang bersama awan-awan putih dan dibawa ke tempat yang tak pernah saya kenal sebelumnya. Saya melihatnya seperti sebuah perkampungan dengan halaman yang luas. Mimpi seperti ini belum pernah saya alami sebelumnya. Apakah pertanda buruk atau baik mimpi saya itu ya? Semua itu tidak saya ambil pusing, mimpi adalah bunganya tidur.

\subsection{Merantau ke Dili, Timor-Timur}

Pada tahun 1992, saya mendapatkan tawaran untuk bekerja mengukir di tempat yang jauh yaitu di Dili, Timor-Timur, yang kala itu masih termasuk salah satu bagian provinsi di Indonesia. Begitu mendapat tawaran bekerja ini, saya langsung bicarakan dengan orang tua dan keluarga, tapi apa jawabnya "Ojo nang, neng Timor-Timur iku daerah rawan lan gawat akeh tentara podo 
gugur neng kono (Jangan "nang" panggilan anak laki-laki, di Timor-Timur itu daerahnya masih rawan dan gawat banyak tentara yang gugur di sana).” Begitu jawaban dari orang tua seakan tidak setuju dan tidak merestui jika saya pergi bekerja di sana. Namun saya mempunyai prinsip di manapun bekerja dan selama masih di wilayah Indonesia, Insya Allah aman. Lebihlebih saya memiliki keyakinan dan juga konon katanya masyarakat di sana sudah dapat menerima siaran televisi swasta. Jadi, saya tambah yakin bahwa kehidupan masyarakat di sana sudah lebih baik dan apa yang dikhawatirkan oleh orang tua saya selama ini hanya untuk menghalangi niat saya.

Ternyata benar juga kata mereka, Timor-Timur adalah daerah konflik yang anti Indonesia. Namun, saya tetap dengan pendirian dan tetap dengan keinginan saya untuk mencari pengalaman dan rejeki di tempat nan jauh. Karena kesempatan ini mungkin tidak akan muncul dua kali, maka tidak akan saya sia-siakan. Walaupun akhirnya saya nekad dan sedikit mengabaikan nasihat orang tua, saya tetap berangkat untuk mengambil kesempatan ini.

Pada bulan Agustus 1992, saya berangkat ke Timor-Timur. Pagi-pagi sekali saya bangun untuk persiapan keberangkatan dengan membawa pakaian dan bekal secukupnya. Lalu saya memohon doa dan restu orang tua dan keluarga, agar dalam perjalanan dan bekerja di sana diberi keselamatan, kemudahan, dan rejeki yang barokah. Orang tua dan saudara-saudara melepas keberangkatan saya ke Timor-Timur dengan meneteskan air mata seakan saya tidak akan kembali untuk selamanya. Kemudian saya berangkat bersama teman-teman menuju ke Surabaya dengan menggunakan bus umum, lalu menuju sebuah penginapan yang sudah disediakan oleh perusahaan.

Sesampainya di penginapan, saya beristirahat sejenak kemudian berjalanjalan keliling kota Surabaya bersama teman-teman pada malam hari, yang tak lebih dari empat jam, kemudian pulang untuk istirahat dan tidur. Baru keesokan harinya, kami dijemput dengan menggunakan mobil perusahaan yang ada di Surabaya menuju Bandara Juanda, Surabaya. Sesampainya di bandara pesawat meninggalkan landasan menuju Denpasar. Tak lama kemudian, saya melihat awan-awan putih yang sangat indah, di dalam benak 
saya berkata, berarti benar dan nyata mimpi-mimpi saya selama ini, akhirnya menjadi kenyataan. Ini merupakan pengalaman pertama saya naik pesawat dan pengalaman yang tidak terlupakan.

Kurang dari satu jam pesawat sudah mendarat di Bandara Ngurah Rai, Denpasar, Bali. Kemudian saya dan teman-teman pindah pesawat yang menuju ke Dili dan kebetulan pesawat yang kami tumpangi adalah pesawat Merpati. Tepat pukul 13.00 waktu Indonesia Bagian Timur, pesawat sudah mendarat di Dili, dengan waktu penerbangan kurang dari empat jam. Dengan mengucap syukur Alhamdulillah, saya dan teman-teman selamat sampai tujuan. Kami turun dari pesawat dan ternyata jemputan dari perusahaan sudah siap. Jarak dari bandara ke lokasi perusahaan di mana saya bekerja cukup dekat, hanya sekitar satu kilometer.

Dalam perjalanan menuju ke perusahaan, saya tengok kiri-kanan, tampak di tepi jalan masih sepi dari bangunan maupun rumah tempat tinggal. Sesampainya di perusahaan, kami disambut oleh pimpinan perusahaan dan acara ramah-tamah untuk perkenalan. Lalu mereka menunjukkan mess sebagai tempat tinggal selama bekerja di sini. Tak lama kemudian, saya dan teman-teman menuju mess untuk melihat keadaan di dalamnya. Ternyata sudah disiapkan tempat tidur dan kebutuhan alat-alat memasak serta perlengkapan lainnya. Lalu saya membaringkan badan sebentar untuk istirahat sejenak.

Namun belum begitu hilang capeknya, sudah ada panggilan untuk diajak makan di luar bersama-sama. Lebih-lebih yang mengajak adalah pimpinan perusahaan, jadi saya langsung semangat selain juga sudah sangat lapar karena hampir seharian belum terisi makanan. Saya dan teman-teman dipersilahkan naik kendaraannya dengan menggunakan mobil hardtop dan beliau berkata "Ayo cari makan, kalian semua lapar kan?" Saya terdiam sejenak dengan rasa malu untuk menjawabnya. Dalam hati sebetulnya merasa senang mempunyai pimpinan yang begitu perhatian kepada anak buahnya. Ini mungkin juga merupakan pelayanan perusahaan yang cukup ternama di Kota Dili ini. Perusahaan yang demikianlah yang saya harapkan bisa menjamin karyawannya, baik dari segi kesehatan, kesejahteraan, dan lainnya. 
Jarak yang ditempuh dari perusahaan ke kota cukup jauh, sekitar $4 \mathrm{~km}$ hanya untuk mencari rumah makan di Kota Dili. Memang agak susah, harus berputar-putar dulu baru ada yang cocok atau sesuai selera. Lalu saya dan teman-teman makan dengan selera masing-masing hingga kenyang. Tak lama kemudian, kami pulang dengan penuh kebahagiaan karena perut sudah terisi penuh. Tidak terasa kami sudah sampai di mess perusahaan.

Saya mengucapkan terima kasih, lalu bergegas ke mess untuk beristirahat sejenak. Kemudian, saya dan teman-teman dihampiri oleh kepala bagian produksi dan diajak masuk ke dalam perusahaan untuk melihat produkproduk yang dikerjakan di dalam perusahaan. Ternyata cukup lengkap dan modern peralatan atau mesin-mesin yang dimiliki. Mesin-mesin tersebut untuk memproduksi barang-barang seperti pena, kipas, tempat pena, dupa, minyak, patung, dan kerajinan lainnya yang terbuat dari kayu cendana.

Ada juga produk lainnya yang dikerjakan oleh perusahaan yaitu kerajinan marmer yang membuat saya terkagum-kagum. Saya juga diperkenalkan dengan karyawan-karyawan lainnya hingga sore hari sampai jam kerja perusahaan tutup.

Sebelum kembali ke mess, saya dan teman-teman mendapat pesan bahwa besok pagi diminta menghadap di bagian personalia perusahaan untuk menandatangani kontrak kerja. Setelah mendengar apa yang disampaikan oleh pimpinan produksi, lalu kami menuju mess untuk membersihkan badan karena seharian belum mandi dan istirahat.

Pagi-pagi sekali saya sudah bangun untuk menyiapkan diri memulai kerja pada hari pertama di tempat ini. Begitu kantor dibuka, saya buru-buru masuk ke dalam ruangan sambil menunggu bagian personalia datang. Tak lama kemudian yang saya tunggu telah datang, saya memberi salam terlebih dahulu dengan ucapan "Selamat pagi, Mbak Rut." dan dia membalas salam saya dan tersenyum ramah. Tak lama kemudian, kontrak diberikan dan saya dipersilakan untuk membacanya. Jika sudah menyetujui isi kontrak baru boleh ditandatangani. Lalu saya baca dengan teliti isi kontrak tersebut dan baru tahu nama perusahaannya yaitu PT. Bathara Indra Group di 
mana salah satu cabangnya ada di Kota Dili dan pusatnya ada di Jakarta. Saya dibayar dengan gaji yang cukup untuk hidup satu bulan dan isi kontrak menjelaskan bahwa kontrak berlaku hanya satu tahun dan dapat diperpanjang setiap tahunnya. Setelah semua isi dalam kontrak saya pahami, kemudian saya tandatangani dengan membaca bismillah dalam hati dengan niat untuk bekerja.

Kemudian saya meninggalkan ruangan kantor dan menuju bagian ruang kerja ukir. Ternyata di situ sudah disiapkan berbagai jenis ukuran kayu cendana untuk diukir patung. Ketika saya mulai untuk mengukir, saya tidak bisa konsentrasi karena ada suara bising mesin pabrik yang begitu kerasnya. Cara untuk mengatasi suara bising tersebut saya coba dengan menutupi telinga dengan kapas. Memang agak mendingan tetapi tidak nyaman di telinga. Namun apa boleh buat, daripada mendengar suara bising dan tidak bisa konsentrasi, terpaksa telinga saya tutup. Setiap hari kerja saya tutup telinga dengan kapas, kadang dibuka sebentar, lalu tutup lagi hingga berlangsung hampir dua minggu baru dapat menyesuaikan suara-suara bising pabrik.

Sudah beberapa hari saya bekerja di perusahaan ini, namun belum begitu bergaul dengan karyawan-karyawan lainnya. Saya harus dapat menyesuaikan dengan lingkungan sekitar perusahaan lebih-lebih dengan orang pribumi Timor-Timur. Karyawan perusahaan ternyata banyak juga orang rantauan seperti dari NTT, NTB, Jawa, Sumatra, Sulawesi, Kalimantan, dan Ambon. Jadi saya merasa tidak sendiri di tempat rantau tapi banyak juga temanteman lainnya yang datang dari berbagai daerah di Indonesia dan semua saya anggap sebagai saudara.

Tidak terasa saya bekerja di perusahaan sudah satu bulan lamanya dan akan menerima gaji untuk pertama kalinya. Gaji itu sudah saya rencanakan untuk membayar makan bulanan dan membeli kebutuhan setiap bulannya. Kalau ingin pergi ke tempat-tempat wisata atau tempat keramaian, saya harus menyisihkan uang sendiri yaitu uang dari lemburan. Perusahaan memberikan kesempatan bagi karyawannya untuk lembur di luar jam kerja harian, jadi kesempatan ini saya gunakan untuk mencari uang tambahan. 
Di samping mengambil kerja lembur, saya juga mengikuti kegiatan-kegiatan lain di luar perusahaan, seperti kegiatan olah raga sepak bola, sepeda santai, maupun kegiatan lainnya. Berbagai kegiatan dan kesibukan ini membuat saya lebih kerasan hidup di perantauan. Saya tidak melulu bekerja dan bekerja saja yang akan terasa sangat membosankan, paling tidak saya dapat menyesuaikan diri dengan lingkungan setempat.

Waktu dan kehidupan terus berjalan, tidak terasa saya bekerja di rantau sudah hampir setahun, namun saya merasa masih ada yang kurang. Setiap hari, saya berpikir bagaimana kehidupan ini tetap berjalan dengan normal. Saya selama ini masih kepikiran janji kepada orang tua yang sampai saat ini masih belum terlaksana yaitu menikah. Mengingat usia saya sudah 26 tahun dan jika saya nikah nanti pada usia tua, kasihan anak keturunan jika orang tuanya sudah tidak dapat bekerja sementara anak-anak masih kecil.

Setelah saya pikir-pikir, akhirnya saya putuskan tahun depan di tahun 1993, saya harus nikah bagaimanapun caranya. Memang semua ini sangat sulit karena: pertama, saya belum mempunyai calon; ke dua jauh dari keluarga; dan ke tiga, modal belum begitu cukup. Memang manusia bisanya hanya merencanakan namun hasilnya nanti atas kehendak-Nya apakah rencana saya bisa terlaksana atau tidak. Namun dalam hati saya sangat yakin sekali rencana ini pasti dapat berjalan lancar, asal niat dan ketulusan itu diimbangi dengan usaha sungguh-sunguh. Maka dengan keyakinan itulah, saya menjadi percaya diri dan setiap kali ada kesempatan untuk bermain ke rumah teman maupun acara lainnya, pasti saya jalani karena dapat menjadi kesempatan untuk mengenal lebih jauh terutama dengan teman wanita.

Sebenarnya banyak teman wanita namun saya belum bisa untuk langsung cepat-cepat memilihnya karena harus mengetahui sifat dan perilakunya terlebih dahulu. Saya tidak bisa seperti memilih kucing di dalam karung, mana yang ketemu duluan langsung diambil dan dianggap cocok. Saya harus hati-hati dan selektif untuk memastikan pilihan hidup. Setelah berbulanbulan lamanya memilih dari beberapa teman wanita, ternyata ada tiga pilihan yang cocok menurut hati nurani. Selanjutnya saya harus memilih salah satu di antaranya karena tidak mungkin dipilih semuanya. Memang semua 
itu butuh pengorbanan dan perjuangan yang penuh risiko demi mencari pasangan hidup yang sakinah, mawwadah, warrohmah.

Akhirnya, saya menemukan pilihan pasangan hidup yang sesuai dengan keinginan dan idaman saya, yaitu gadis yang berasal dari Kota Makassar, Sulawesi Selatan. Gadis ini adalah teman bekerja saya di perusahaan yang sama. Dia ternyata memiliki perasaan yang sama dengan saya. Setiap kali liburan kerja, saya sempatkan pergi bersama untuk berlibur ke pantai atau ke mana saja yang penting bisa jalan-jalan berdua. Bahkan pergi memenuhi acara undangan pun saya lakukan. Kadang saya berpikir kenapa menjadi senekat ini, padahal jauh dari sanak saudara dan keluarga, tetapi hal ini tidak menjadi halangan yang berarti.

Dukungan dan motivasi tetaplah ada dari teman-teman, terutama dukungan dari pimpinan perusahaan. Saya beranggapan bahwa teman-teman di perantauan adalah saudara-saudara yang paling dekat dan paling hebat. Kurang lebih sepuluh bulan saya berpacaran dengan gadis idaman saya. Pada akhirnya, saya putuskan untuk menikah saja dari pada nanti terjadi hal-hal atau gangguan-gangguan lain yang tidak saya inginkan. Pada suatu hari, saya membicarakan rencana pernikahan ini kepada teman-teman dan mereka sangat terkejut mendengarnya. Lalu saya minta tolong salah seorang teman agar dapat mendampingi saya nanti dalam menyampaikan pembicaraan mengenai lamaran dan sekaligus jadwal pernikahan kepada keluarga calon istri saya. Kemudian esok harinya, saya datang ke rumah keluarganya sekitar pukul 19.30 waktu setempat dengan didampingi teman. Kebetulan juga rumahnya tidak jauh dari tempat kerja jadi kami cukup jalan kaki saja. Setelah disambut dan dipersilakan masuk rumah, saya utarakan dengan hatihati maksud dan tujuan kedatangan saya dan tak lama akhirnya mendapat persetujuan dari pihak keluarganya. Saya sangat bersyukur kepada Allah SWT karena rencana-rencana saya mulai terurai satu persatu tanpa halangan.

\subsubsection{Pernikahan di Dili dan syukuran di Makassar}

Pada tanggal 2 Oktober 1993, saya melaksanakan pernikahan di kantor urusan agama (KUA) Kota Dili, dengan Ijab Kabul di hadapan penghulu dan saksi-saksi. Pernikahan kami hanya dilaksanakan di KUA, tetapi tidak 
menjadi halangan dan kenyataannya dapat berjalan dengan hikmad dan lancar. Saya mengucapkan terima kasih pada teman-teman atas dukungannya dan khususnya kepada pimpinan perusahaan yang sudi menjadi saksi dalam pernikahan hingga selesainya acara.

Setelah acara pernikahan usai, langsung temanteman saya ajak ke rumah untuk menikmati

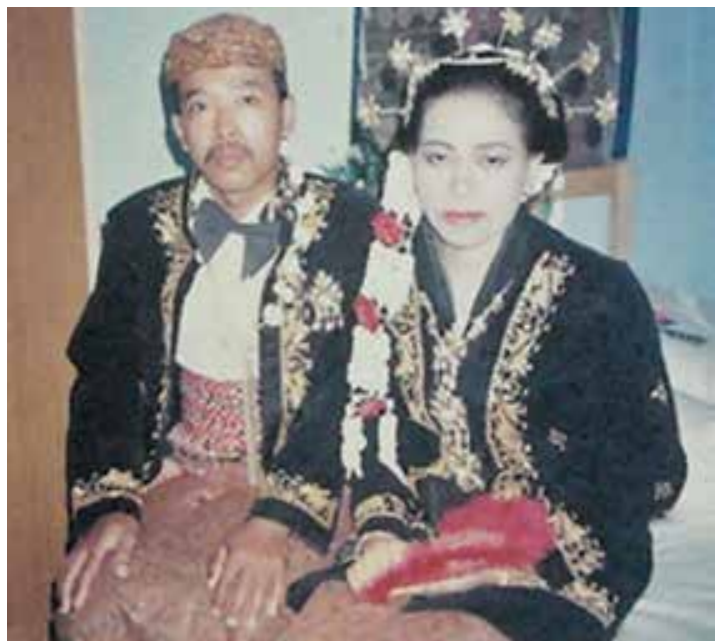

Gambar 5.2. Pernikahan kami di Kota Dili tanggal 2 Oktober 1993

hidangan makan yang sudah disediakan oleh pihak keluarga istri. Memang dari pihak keluarga mengadakan acara sederhana untuk menyambut pernikahan ini. Seminggu sudah pernikahan berjalan, saya dan istri merencanakan pulang ke Makassar untuk menemui orang tua dan keluarga di kampung.

Pagi-pagi sekali, kami sudah berada di Pelabuhan Dili untuk mempersiapkan keberangkatan menuju Makassar. Perjalanan ini sangatlah jauh kalau ditempuh dengan kapal laut memakan waktu dua hari dua malam.

Perjalanan dengan kapal laut sangatlah menyenangkan karena tidak merasakan goncangan ombak laut dan seperti di rumah besar biasa. Akhirnya kapal berlabuh dengan selamat di Kota Makassar pada pagi hari pukul tujuh waktu setempat. Segera kami mencari angkutan menuju Kabupaten Maros yang perjalanannya ditempuh kurang lebih satu jam. Sesampainya di rumah ibu angkatnya, saya bersama istri disambut gembira dan penuh kekeluargaan. Kami kemudian beristirahat dan menginap semalaman karena besok pagi masih melanjutkan perjalanan ke Camba. 
Saya sudah bangun pagi-pagi dan siap untuk melanjutkan perjalanan ke Camba, hanya cukup jalan kaki saja untuk menuju pangkalan angkutan ke Camba. Ternyata perjalanan ke Camba cukup jauh dan jalannya berbelokbelok. Hampir empat jam kami menghabiskan waktu di perjalanan untuk menuju ke Camba. Saya merasa tersanjung karena di rumah sudah banyak sanak-saudara dan tetangga yang menunggu kedatangan kami. Kami memperkenalkan diri kemudian ngobrol-ngobrol untuk mengakrabkan persaudaraan. Sanak saudara dan para tetangga di sekitar rumah memang sengaja diundang oleh pihak keluarga untuk membantu dalam menyambut acara syukuran pernikahan kami. Keesokan harinya saya bangun pagi-pagi untuk persiapan acara syukuran pernikahan yang dilaksanakan oleh keluarga dengan menggunakan adat dan budaya Bugis. Acarapun dimulai dengan suasana hening dan penuh kedamaian.

Para sesepuh, pinisepuh, tokoh-tokoh desa dan para sanak saudara berkumpul untuk menyaksikan acara syukuran pernikahan yang sederhana itu. Acaranya berjalan lancar. Akhirnya acara syukuran pernikahan usai dan kembali seperti biasa. Esok harinya, seharian saya diajak jalan-jalan melihat suasana pedesaan dan juga diajak ke rumah saudara-saudara istri untuk lebih mengakrabkan persaudaraan. Rasa rindu dengan keluarga masih belum pulih, namun karena ada tugas pekerjaan di perusahaan yang harus saya lakukan dengan profesional, maka kami harus segera kembali ke Dili.

\subsubsection{Kembali ke Dili dan bekerja di perusahaan}

Pagi-pagi kami sudah bangun untuk menyiapkan diri pulang ke Dili. Memang berat rasanya berpamitan dengan orang tua mengingat rasa rindu yang belum terobati. Maksud hati ingin tinggal lama-lama di rumah orang tua, namun tuntutan hidup dan pekerjaan maka harus kembali ke Dili. Lalu saya berpamitan dan memohon doa restu orang tua agar perjalanan kami pulang tidak ada halangan suatu apa pun dan semoga diberi keselamatan sampai tujuan. Perjalanan dari kampung hingga ke pelabuhan Makassar cukup jauh, sekitar enam jam. Karena itu saya ingin menginap di Maros lagi semalaman sambil berpamitan dengan keluarga. 
Pagi harinya, saya berpamitan dan langsung menuju ke pelabuhan Makassar, lalu naik kapal laut menuju Dili. Setelah dua hari dalam perjalanan, akhirnya sampai juga dengan selamat di Dili. Saya dan istri harus cepat-cepat masuk kerja karena izin cuti nikah telah habis dan kami tidak mau bermalasmalasan dengan alasan apa pun.

Di hari pertama setelah nikah, saya dan istri mulai masuk kerja kembali di perusahaan seperti biasa, bergabung dengan teman-teman lainnya. Setiap hari, kegiatan saya adalah bekerja dan bekerja, tidak hanya mengerjakan ukir-ukiran saja tetapi juga mengerjakan pekerjaan sampingan servis elektro. Untuk meluangkan waktu dengan lingkungan masyarakat baru saya sempatkan di hari-hari libur. Mengingat saya belum berpengalaman tentang kehidupan berkeluarga, saya memanfaatkan kesempatan ini untuk belajar dan melakukan yang terbaik di lingkungan sekitar walaupun waktu saya sangat terbatas.

Kehidupan bermasyarakat membuat saya tambah mengerti dan memahami arti kehidupan yang sebenarnya, karena bermasyarakat itu tidak memandang golongan, agama, maupun etnis, semuanya bersatu padu. Setelah sekian lama menempati mess yang disediakan oleh perusahaan bersama teman-teman, akhirnya saya memutuskan untuk pindah rumah dengan biaya sendiri. Saya ingin belajar hidup satu atap satu keluarga, di samping itu istri saya sedang hamil tua. Jadi saya harus menyiapkan kebutuhan rumah tangga sendiri dan kebutuhan perlengkapan kelahiran anak pertama. Alasan lainnya adalah saya tidak mau mengganggu kegiatan teman-teman dan juga ingin berdekatan dengan rumah keluarga istri.

Setelah menempati rumah kontrakan dalam beberapa minggu, saya rasakan kedamaian dan ketenteraman berumah tangga karena sedang menanti kelahiran si jabang bayi dan sebentar lagi akan dipanggil bapak.

Pada suatu malam, perut istri saya mulai terasa sakit sekali. Dalam pikiranku ini pasti mau melahirkan dan tak lama kemudian saya bawa ke rumah sakit umum di Kota Dili. Perjalanan dengan sepeda motor pada tengah malam itu 
saya sangat was-was sekali dan pikiran saya hanya berdoa dan berdoa, semoga selamat sampai tujuan, walaupun saya harus berangkat untuk mengantarnya dalam suasana kota yang sedang rawan. Syukur alhamdulillah kami sampai di rumah sakit dengan keadaan selamat dan langsung saya bawa ke ruang bersalin. Saya tunggu-tunggu semalaman belum ada tanda-tanda kelahiran dan sampai pagi pun masih sama, istri saya hanya merasakan kesakitan di bagian perut.

\subsubsection{Menanti kelahiran anak pertama}

Akhirnya pukul 10 pagi tanggal 3 April 1995, lahirlah seorang anak perempuan secara normal dengan sehat. Saya bersyukur sekali ke hadirat Yang Kuasa karena diberi anugerah yang tak terhingga nilainya. Dengan kelahiran anak pertama ini akan menambah kelengkapan keluarga saya. Untuk merawat si kecil perlu waktu dan tenaga ekstra agar dapat berkembang dengan baik. Namun saya belum mempunyai pengalaman merawat anak, oleh karenanya mertua dari Makassar diminta datang ke Dili agar dapat ikut merawat serta mengawasi pertumbuhan si kecil. Satu bulan lamanya mereka tinggal di rumah dan setelah kami dirasa mampu dan tahu cara merawat si kecil, mereka lalu pulang ke Makassar.

Beberapa hari kemudian, setelah kepulangan orang tua ke Makassar, saya mengadakan syukuran untuk memberi nama si kecil Putri Lestari dengan harapan semoga ia menjadi seorang wanita yang sesuai dengan keluhuran kewanitaannya dan juga sholehah.

Bulan berganti bulan, saya melihat petumbuhan si kecil yang semakin besar, sehat, dan lucu, namun yang menjadi pemikiran saya adalah bagaimana untuk mencari tenaga yang dapat merawat si kecil karena sebentar lagi istri akan masuk kerja lagi karena masa cuti melahirkan telah habis. Lalu saya minta tolong kepada teman untuk mencarikan saudaranya untuk dapat membantu merawat si kecil. Keesokan harinya teman saya sudah membawa orang ke rumah yang bersedia merawat si kecil, lega rasanya kami. Istri sekarang mulai fokus kembali ke pekerjaan di perusahaan. 
Pekerjaan membuat ukiran patung dari perusahaan semuanya dapat selesai dengan baik dan kadang pula saya diminta untuk menggantikan menjadi pemeriksa produksi atau kontrol kualitas. Ukiran patung dan produkproduk kerajinan lainnya akan diperiksa terlebih dahulu sebelum masuk ke gudang dan untuk dipasarkan. Di samping itu, perusahaan juga memberikan jaminan kesehatan atau jamsostek kepada karyawannya apabila sakit atau hal lain yang berhubungan dengan kesehatan, jadi bekerja merasa terlindungi dari masalah kesehatan.

Sekitar tiga tahun sudah saya bekerja di PT. Bathara Indra Group dan saya berencana ingin pulang kampung bersama keluarga. Memang keinginan dan rencana pulang kampung ke Jepara sudah ada sejak lama, namun tertundatunda karena banyak kebutuhan keluarga. Akhirnya, pada bulan November 1995, keinginan pulang ke Jepara terlaksana, dan waktu itu si kecil baru berumur tujuh bulan jadi masih ragu dengan kekuatan tubuhnya. Kami memilih perjalanan pulang dengan pesawat menuju Bali. Dua jam perjalanan kemudian sampailah di bandara Denpasar, lalu dilanjutkan dengan naik bus ke Semarang dan dengan taksi ke Jepara. Kurang lebih selama dua jam perjalanan, sampailah kami di Jepara dengan selamat dan si kecil baikbaik saja.

Begitu sampai di depan rumah, saya langsung disambut dengan penuh kebahagiaan dan kerinduan karena begitu lama tidak pulang. Orang tua dan saudara-saudara sangat kangen lebih-lebih kepada si kecil. Seharian saya beramah-tamah dengan keluarga dan tetangga dekat akhirnya capek dan istirahat sejenak. Namun tak lama setelah bangun, kami kembali ngobrol-ngobrol sampai malam. Saya perhatikan di rumah sepertinya sedang menyiapkan suatu acara.

Ternyata benar, pagi-pagi sekali sudah banyak sanak saudara yang datang ke rumah untuk membantu pelaksanaan syukuran si kecil. Sebagai anak perempuan ia harus disunat dan bila tidak akan memengaruhi pertumbuhannya. Menurut tradisi orang Jawa, konon katanya apabila tidak dilaksanakan sunatan jika kelak besar nanti tidak laku kawin. Setelah semua acara sunatan selesai, saya bersiap untuk kembali ke Dili. 
Pagi sebelum subuh saya sudah bangun dengan semua persiapan yang saya anggap sudah cukup. Kami lalu berpamitan dan mohon doa restu kepada orang tua dan saudara agar selamat dan sehat sampai tujuan. Kami menuju ke terminal Semarang dan sekalian membeli tiket kapal laut, kemudian ke Surabaya dengan menggunakan bus malam. Sesampainya di Surabaya pukul enam pagi, kami langsung ke pelabuhan Tanjung Perak. Hanya menunggu sekitar tiga puluh menit di atas kapal, kapal kemudian berangkat meninggalkan pelabuhan. Perjalanan dengan kapal laut dari Surabaya menuju Dili berlangsung sekitar dua hari. Selama perjalanan ini si kecil baik-baik saja. Setelah dua hari akhirnya sampai juga di pelabuhan Dili pada pukul delapan malam dalam keadaan sehat dan selamat, lalu kami langsung mencari taksi ke arah rumah di Comoro. Perjalanan dari pelabuhan sekitar dua puluh menit dan alhamdulillah sampailah kami di rumah.

Keesokan harinya, saya sudah masuk kantor seperti biasa. Saya sekarang tidak lagi menjadi karyawan kontrak, melainkan karyawan borongan. Jadi saya tidak terikat dengan perusahaan dan begitu juga dengan teman lain yang seprofesi. Bekerja borongan juga bisa dirasakan enaknya akan tetapi bergantung pada kesungguhannya untuk bekerja; kalau giat bekerja pasti ada hasil lebihnya. Bekerja borongan memberi kesempatan saya untuk lebih giat dalam mencari lebih banyak uang untuk keluarga dan beberapa bulan ke depan akan ada tambahan anggota keluarga baru.

Memang kebutuhan-kebutuhan keluarga makin hari makin bertambah dan jika tidak bekerja lebih giat tentu akan menambah beban yang harus saya tanggung. Sebetulnya saya masih beruntung dibantu oleh istri karena status istri sebagai karyawan tetap di perusahaan dengan gaji lumayan setiap bulan untuk membantu kebutuhan keluarga. Di saat-saat perusahaan memberikan kesempatan bekerja borongan kepada karyawannya, tentu saja hal ini memicu semangat untuk bekerja lebih giat. Namun pekerjaan borongan ini tidak dapat berlangsung lama dan juga sangat disayangkan, makin hari makin berkurang pekerjaannya sehingga makin banyak pula temanteman yang dipulangkan ke Jawa satu persatu. Saya tidak tahu mengenai manajemen perusahaan namun yang saya ketahui pada saat itu adalah mengenai keamanan yang mulai tidak kondusif lagi. 


\subsubsection{Menjadi anggota ORARI Timor-Timur}

Waktu itu kebetulan saya sudah masuk dalam keanggotaan ORARI (Organisasi Radio Amatir Indonesia) di Timor-Timur pada tanggal 15 Maret 1995, dengan nama panggilan di udara YD9RXM. Keanggotaan ini memungkinkan saya dapat memantau keadaan yang sebenarnya lewat perangkat komunikasi yang saya miliki. Bahkan pernah saya lakukan penyadapan dari alat komunikasi milik Polri dan ABRI demi ingin mengetahui dan mendapatkan informasi dan kadang pula bertanya langsung kepada teman sesama anggota.

Selama saya menjadi anggota ORARI, sedikit banyak saya mengetahui perkembangan dan situasi di daerah Dili dan sekitarnya. Bahkan saya pernah diberi tugas untuk memantau dan juga membantu kelancaran kegiatankegiatan seperti: bencana alam, Porda (Pekan Olah Raga Daerah) dan kegiatan adat Timor, serta berbagai kegiatan olahraga lainnya. Gentingnya situasi di Timor-Timur menjadi alasan perusahaan mengurangi karyawannya untuk dirumahkan. Hal ini wajar-wajar saja karena perusahaan memberikan pesangon dan melakukan hal yang tidak melanggar tatanan ketenagakerjaan yang diatur oleh pemerintah.

Setelah perusahaan mengurangi karyawannya, keadaan di pabrik saat itu sangat lengang dan tidak begitu bising karena aktivitas banyak yang berkurang. Akhirnya tukang pengukir tinggal lima orang yang masih ditangguhkan bekerja untuk menyelesaikan pekerjaan pesanan yang harus diselesaikan sebelum akhir tahun. Walaupun pekerjaan mulai berkurang dan karyawannya pun juga berkurang, saya tetap giat bekerja, karena waktu bekerja di perusahaan yang hanya tinggal beberapa bulan ke depan. Saya harus dapat menyiapkan diri sedini mungkin manakala tidak lagi bekerja di perusahaan ini.

Waktu terus berjalan dan pekerjaan pun mulai berangsur-angsur selesai lebih awal dari prakiraan akhir tahun. Teman-teman pulang satu-persatu dan karyawan lainnya dipulangkan hingga perusahan benar-benar tutup dengan alasan keamanan tidak kondusif. Langkah-langkah perusahaan ini sudah 
benar termasuk kewajiban-kewajibannya terhadap karyawan sudah terpenuhi sesuai dengan aturan ketenagakerjaan.

Di saat-saat menjelang perusahaan mau tutup, saya masih diberi kesempatan untuk menempati mess hingga akhir tahun 1996. Seperti biasanya, saya bangun pagi dan mengajak si kecil jalan-jalan di sekitar perusahaan. Tibatiba, istri saya mengajak ke rumah sakit bersalin. Kemudian si kecil saya titipkan ke orang kepercayaan saya yang dulunya pernah bantu-bantu di rumah dan kami cepat-cepat ke rumah sakit bersalin terdekat.

\subsubsection{Menanti kelahiran anak kedua}

Tak lama ditangani oleh perawat persalinan selama kurang lebih sepuluh menit, lahirlah seorang anak laki-laki secara normal dan sehat. Dengan mengucap alhamdulillah atas kelahiran anak ke dua, saya memberinya nama Putra Setiawan yang lahir pada hari Minggu, tanggal 10 November 1996, pukul 08.00 pagi waktu setempat. Kami menyambut dengan diiringi doa semoga menjadi anak laki-laki yang setia, jujur, dan berguna bagi nusa bangsa. Setelah beberapa hari di rumah sakit, akhirnya istri dan anak saya bawa pulang. Waktu itu di mess kelihatan sepi padahal biasanya ramai banyak teman. Dengan pengalaman anak pertama, paling tidak kami dapat merawat si kecil walaupun tentu ada kekurangan-kekurangannya. Ketika itu saya berbagi tugas untuk merawat anak-anak yang masih kecil dan semua itu saya maklumi dan sadari karena jauh dari orang tua serta saudara. Hal terpenting adalah bagaimana langkah ke depan supaya dapat membesarkan anak-anak ini dengan kemandirian orang tuanya.

Mengingat waktu yang diberikan oleh perusahaan untuk menempati mess hanya tinggal beberapa minggu lagi, saya harus dapat memutuskan antara pulang ke Jepara atau tetap tinggal di Dili dengan membuka usaha baru dengan semua risiko yang harus dilewati. Usaha baru yang saya rencanakan adalah membuka usaha servis elektro dan usaha ukiran di tempat yang padat perumahan. Alhamdulillah dalam kebimbangan ini, saya diberi pekerjaan mengukir akar kayu cendana dari pimpinan perusahaan dan katanya ukiran itu untuk hadiah, jadi minta dibuatkan yang bagus. Dalam waktu yang tersisa itu, saya gunakan sebaik mungkin untuk mengerjakan pekerjaan 
mengukir sementara juga harus dapat meluangkan waktu untuk mengurus akte atau surat-surat kelahiran anak-anak di kantor Desa Comoro dan kantor pemerintahan catatan sipil Kota Dili. Dalam waktu yang sangat sempit ini saya harus dapat menyelesaikan berbagai masalah terutama keluarga dan pekerjaan.

Dengan semangat kerja keras dan berbagai cara untuk meluangkan waktu, akhirnya pekerjaan dapat saya selesaikan dengan baik. Setelah pekerjaan mengukir itu selesai, saya menerima upah yang sesuai dengan hasil karya seni yang saya buat. Setelah semua urusan dan masalah dapat selesai sesuai jadwal yang direncanakan, dalam hati saya ingin melanjutkan rencana membuka usaha baru, maka harus bertindak secepatnya. Namun tidak terasa waktu sudah di akhir tahun dan di sela-sela waktu itu saya manfaatkan kesempatan untuk mencari-cari rumah kontrakan yang strategis dan akhirnya ada yang sesuai namun harganya cukup mahal.

Walaupun waktu itu sempat bernegosiasi dengan yang punya rumah, harganya tidak bisa turun lagi. Lalu saya pulang karena tidak berani memutuskan sendiri dan perlu dimusyawarahkan dengan istri. Setelah tahu harga kontrakan sangat mahal maka saya diminta untuk membatalkan saja niat membuka usaha di Timor-Timur. Istri saya juga mengutarakan keinginannya pulang ke Jepara daripada di Dili yang situasinya tidak menentu.

\subsection{Pulang kampung ke Jepara}

Akhirnya saya putuskan pulang ke Jepara dengan keluarga. Semua barang yang saya miliki dijual, seperti sepeda motor, almari pakaian, tempat tidur, dan alat-alat rumah tangga. Masih ada barang-barang rumah tangga lainnya yang belum terjual dan supaya tidak membebani kepulangan saya nanti, barang-barang tersebut saya kemas hingga menjadi dua boks ukuran besar dengan menggunakan triplek dan kayu supaya aman dalam pengiriman. Baru esok harinya, saya kirim melalui paket pos reguler di Kota Dili. Menurut pegawai kantor pos, diprakirakan barang sampai di Jepara sekitar dua puluh hari lagi. Bagi saya hal ini tidak masalah, yang penting barang sampai di tujuan dalam keadaan aman dan baik. 
Sesampainya di mess, saya segera menyiapkan barang-barang bawaan untuk kepulangan nanti, terutama pakaian anak-anak dan juga perlengkapan lainnya. Saya dan istri tinggal menghitung hari saja karena sebentar lagi akan meninggalkan Kota Dili yang selama ini menjadi saksi kisah kehidupan yang tak terlupakan. Kami tetap berharap semoga Kota Dili tetap menjadi tempat yang aman dan damai. Namun anak pertama tampaknya tidak mengizinkan atau merestui orang tuanya meninggalkan Dili, karena dia tiba-tiba sakit panas dan terus tambah tinggi juga sempat kejang-kejang. Saya berupaya sebisa mungkin untuk dapat menurunkan panasnya dengan mengompreskan air es. Ketika panasnya mulai turun, saya bawa ke dokter praktik spesialis anak untuk mendapatkan perawatan medis. Dalam kepanikan waktu itu, saya sampai lupa mengantri seperti pasien-pasien lainnya.

Setelah mendapatkan perawatan dan pemeriksaan dari dokter, saya diberi resep untuk membeli obat di apotik dan dokternya berpesan bila nanti kejang-kejang lagi obat tersebut dapat digunakan sesuai petunjuk. Kami kemudian pulang dengan taksi untuk beristirahat karena waktu itu sudah sekitar pukul sembilan malam. Keadaan si kecil masih panas namun tidak terlalu tinggi. Semalaman saya menjaganya untuk melihat perkembangan obat yang diberikan oleh dokter. Hingga pagi badannya masih tetap panas walaupun tidak terlalu tinggi dan juga lemas sekali. Saya sangat mengkhawatirkannya dan merasa kasihan panasnya tidak turun-turun.

Akhirnya anak saya bawa ke rumah sakit umum di Kota Dili dengan harapan panasnya bisa terobati. Sehari semalam lamanya saya menunggu di rumah sakit namun dokter belum berani memberikan obat kepada si kecil. Malah saya kena teguran dari dokter yang ternyata orangnya sama dengan yang menangani waktu saya periksa ke tempat praktiknya. Tanyanya "Kenapa putri bapak dibawa ke sini? Putri bapak besok pagi dibawa pulang saja, karena dia lemas itu adalah pengaruh obat yang diberikan kemarin.” Pagi sebelum subuh si kecil sudah bangun dan bermain-main di atas tempat tidurnya, saya jadi kaget dan terbangun dari tidur, kemudian saya pegang badannya dan ternyata sudah turun panasnya. Syukur alhamdulillah putriku sudah sembuh. Sambil menunggu waktu agak siang, saya berkemas-kemas menyiapkan kepulangan. Pada pukul delapan pagi, saya keluar dari rumah 
sakit sambil menggendong si kecil dengan penuh kegembiraan karena ia sudah sembuh dan sehat seperti sediakala.

Saya merencanakan pulang ke Jepara di awal Januari 1997 dengan menggunakan kapal laut yang memakai kamar tersendiri, mengingat anakanak yang masih kecil dan demi menjaga kesehatan, kenyamanan, dan keamanan. Kami khawatir sekali bila di kelas ekonomi mungkin ketahanan tubuh anak-anak belum begitu kebal untuk berbaur dengan berbagai penumpang lain. Selain itu, kemungkinan besar dapat terganggu oleh orangorang di sekelilingnya dan juga dari segi kenyamanan serta keamanan tidak begitu terjamin.

Keberangkatan hanya tinggal menunggu beberapa jam saja karena kapal dijadwalkan akan berlabuh dan bersandar pada pukul 16.00. Saat yang ditunggu-tunggu pun tiba, waktunya untuk berangkat menuju ke pelabuhan, lebih baik menunggu kapal datang daripada ketinggalan kapal. Tak lama kemudian kapal tiba dan saya segera membawa keluarga naik ke kapal dan mencari nomor kamar sesuai tiket. Setelah berdesak-desakan dengan penumpang lain, akhirnya sampailah di kamar dan anak-anak saya baringkan di tempat tidur agar dapat menyesuaikan suasana ruangan kamar. Sekitar dua jam lamanya kapal berlabuh untuk menunggu penumpangnya sebelum meninggalkan pelabuhan Kota Dili.

\subsection{Merintis usaha di Jepara}

Pada tanggal 10 Januari 1997, saya kembali menginjakkan kaki di Jepara. Kepulangan saya bersama keluarga disambut dengan penuh kegembiraan. Saya memulai dan menata kehidupan baru bersama keluarga kecil di kampung halaman. Saya juga harus dapat menyesuaikan diri dengan lingkungan sekitar.

Sekitar dua bulan sudah saya tinggal di kampung bersama keluarga dan kehidupan terus berjalan, namun saya belum melakukan tindakan yang menghasilkan sesuatu. Oleh karena itu, rencana untuk mendirikan kios servis elektro yang tertunda waktu di Dili akan saya bangun di kampung, sebagai usaha cadangan selain mengukir. Mengingat di kampung belum ada 


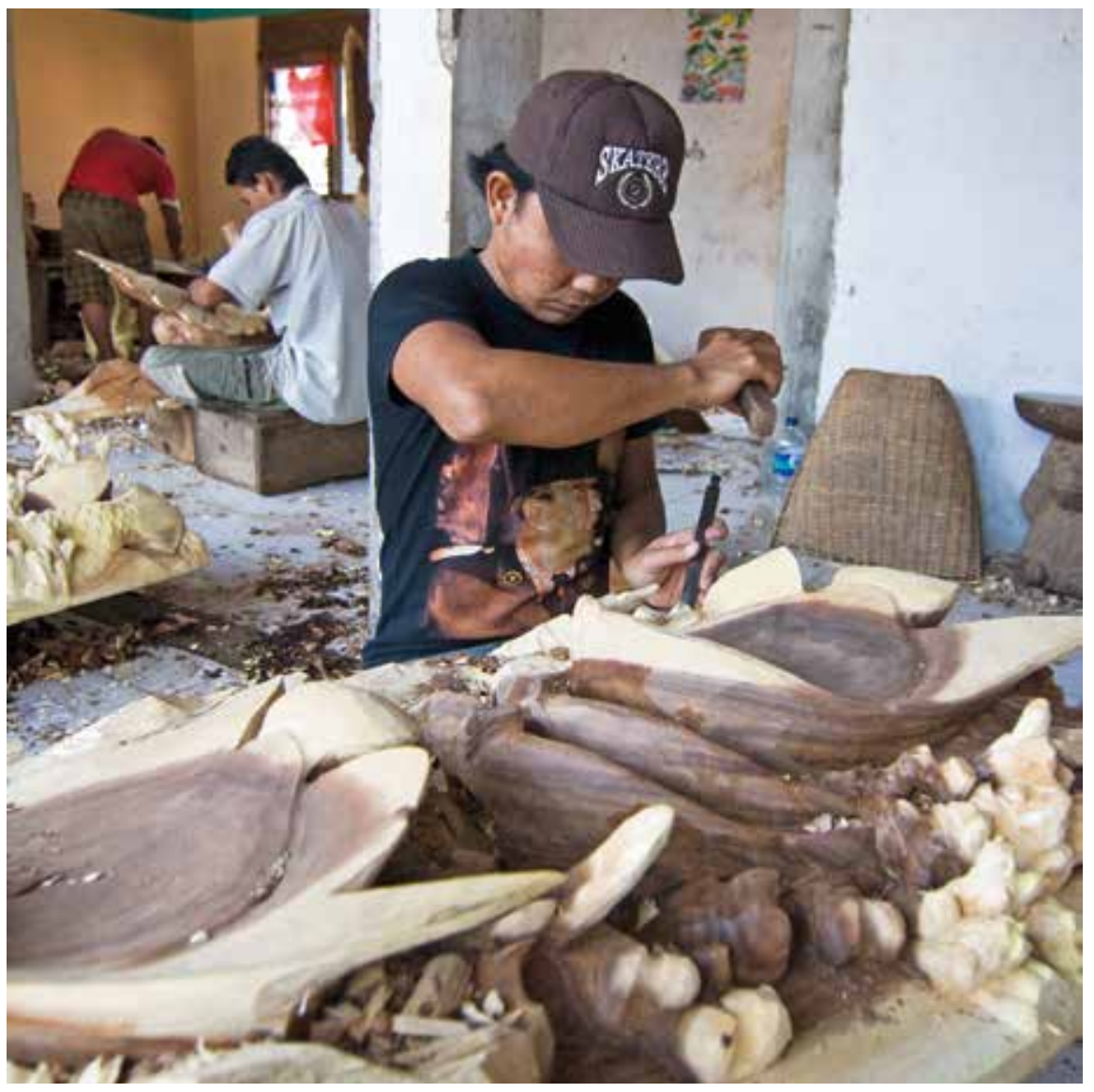

Gambar 5.3. Proses menghasilkan karya patung ukir

pesaingnya, paling tidak setiap bulannya saya mendapat penghasilan untuk memenuhi kebutuhan keluarga. Saya sangat optimis kalau membuka usaha jasa servis elektro ini pasti dapat berjalan dengan baik.

Bulan Maret 1997, saya mulai membangun kios di depan rumah orang tua dengan ukuran tidak begitu besar dan yang penting dapat untuk bekerja. Pembangunan kios tidak lebih dari satu bulan dan sudah dapat ditempati 
untuk bekerja, namun barang-barang elektro milik pelanggan sudah banyak yang antri untuk giliran diperbaiki. Saya kadang bekerja sampai larut malam untuk dapat menyelesaikan pekerjaan servis agar pelanggan tidak merasa kecewa. Saya ingin memberikan pelayanan yang terbaik kepada pelanggan supaya barangnya cepat selesai.

Setelah saya tekuni lebih dari satu bulan lamanya dan pekerjaan ini memberikan pendapatan yang lumayan. Namun saya ingin juga memanfaatkan keterampilan mengukir patung untuk waktu-waktu senggang, karena saya melihat potensi di kampung belum begitu banyak pengukir yang terampil dan mahir. Pada waktu itu, pemilik usaha kerajinan hanya ada sekitar lima belas perajin patung dan mebel. Kesempatan untuk mengukir masih banyak dan paling tidak kesempatan ini harus dapat dimanfaatkan terutama untuk jasa pengukirnya. Karena sebagian besar perajin belum memiliki pengukir tetap dan terampil yang dapat diandalkan jika sewaktuwaktu ada pesanan mereka masih menggantungkan pengukir dari luar yang sekiranya mau dan mampu untuk mengerjakan pekerjaan yang sesuai dengan permintaan pembeli atau sesuai dengan gambar yang ada.

Suatu saat saya mencoba menawarkan jasa sebagai pengukir patung di salah satu pemilik usaha kerajinan yang langsung diterima dan diberi pekerjaan. Kemudian pekerjaan itu saya kerjakan di rumah dan selesai lebih cepat. Namun sebelum saya setorkan kepada pemiliknya malah sudah dibawakan pekerjaan lainnya. Saya pikir pekerjaan ini jika saya kerjakan sendiri tidak akan selesai dengan waktu tertentu, maka saya harus mencari teman untuk ikut membantu mengerjakannya. Dengan persiapan tempat kerja yang seadanya, hanya berupa terpal plastik sebagai atapnya dan tiang bambu, saya menggunakannya sebagai tempat usaha buruh tukang ukir.

Saat itu saya belum mempunyai modal yang cukup untuk membuka usaha sendiri, namun dengan niat yang tulus dan usaha keras, saya yakin suatu saat pasti dapat memilikinya. Untuk mengerjakan pekerjaan ukir patung yang ukurannya lebih besar pastinya tidak dapat dikerjakan sendiri dan tentunya butuh bantuan tenaga dari yang lain. Saya dibantu tiga orang tenaga ukir untuk mengerjakan ukiran patung besar karena pesanan ini harus 
diselesaikan dengan waktu yang sudah dijadwalkan. Jadi pekerjaan yang menjadi tanggung jawab yang sudah dibebankan kepada saya harus dapat diselesaikan tepat waktu, bagaimanapun caranya. Saya dan teman-teman harus bekerja dengan sungguh-sungguh sampai lembur supaya pekerjaan cepat selesai dan kepercayaan tetap terjaga dengan harmonis.

Hari berganti hari, bulan berganti bulan, pekerjaan tetap lancar karena semakin bertambah pemilik usaha yang memberikan pekerjaan. Dari penghasilan mengukir saya dapat menyisihkan sebagian setiap kali mendapatkan upah dan dari beberapa penghasilan lain, saya kumpulkan untuk rencana membuat pondasi rumah. Saat itu saya belum memiliki tempat tinggal dan masih satu atap dengan orang tua dan adik-adik. Jadi apapun kesulitannya, saya harus tetap berusaha untuk mandiri dari keluarga.

Di bulan Agustus 1997, pembangunan pondasi rumah mulai berjalan dan saya harus menyiapkan biaya dan material yang dibutuhkan oleh pekerja bangunan dan perlahan namun pasti, berjalanlah pembangunan rumah. Akhirnya pembangunan gubug kecil sebagai tempat tinggal keluarga dapat ditempati walaupun baru selesai separuhnya, yang penting dapat untuk berteduh.

Pada tanggal 29 Desember 1997, keluarga kami mulai pindah dari rumah orang tua. Saya tidak mempunyai cukup biaya untuk menyelesaikan pembangunan rumah hingga betul-betul layak sebagai tempat tinggal karena saya hanyalah seorang tukang ukir dengan penghasilan pas-pasan. Namun saya percaya dan asalkan bekerja dengan sungguh-sungguh, Insya Allah ada jalan keluar untuk memperbaiki rumah walaupun sambil berjalan atau bertahap. Sekitar enam bulan saya sudah menempati dan tinggal di rumah kecil sebagai tempat tinggal yang sederhana. Pergaulan kami di lingkungan masyarakat umumnya juga menjadi lebih baik.

\subsection{Berorganisasi kemasyarakatan secara aktif}

Kepercayaan masyarakat terhadap saya mulai tumbuh dan saya dipilih sebagai panutan di lingkungan sekitar untuk menjadi ketua wilayah 
Rukun Tetangga (RT). Ini merupakan beban yang sangat berat manakala kepercayaan yang diberikan ternyata tidak dapat terlaksana dengan baik. Namun saya harus benar-benar berusaha agar dapat melaksanakan dan menjaga apa yang menjadi amanah dari warga.

Setelah beberapa bulan menjadi ketua RT, saya pun dipercaya menjadi ketua pemuda dan kesenian di tingkat Desa Mulyoharjo. Jadi beban saya semakin berat tetapi semua ini saya sadari sebagai amanah. Syukur alhamdulillah saya dapat membagi waktu antara kepentingan keluarga dan keperluan lingkungan masyarakat sehingga semua dapat berjalan lancar.

Perjalanan hidup manusia memang sudah digariskan oleh Yang Kuasa dan manusia hanya tinggal menjalani sesuai perintahnya, jadi apa yang telah saya jalani selama ini sudah menjadi kondratnya. Walaupun demikian, manusia tetap harus berusaha demi untuk memenuhi kebutuhan hidup dan kesejahteraan keluarganya dan juga kepentingan umum, dan lebih pentingnya lagi hidup bermasyarakat dengan penuh kedamaian dan ketenteraman. Singkat kata, kehidupan keluarga saya dari tahun ke tahun semakin membaik dan mungkin saja ini sebagai anugerah Yang Kuasa. Kadang kalanya kehidupan saya juga mengalami kesusahan, namun semua dapat dilewati secara perlahan.

Memang perjalanan hidup yang selama ini saya alami tidak semuanya mulus dan lancar. Liku-liku saya alami karena saya menyadari bahwa tidak ada yang saya banggakan lagi selain tenaga, pikiran, dan keterampilan yang dimiliki. Dengan kemampuan inilah yang saya banggakan untuk dapat menghidupi dan memenuhi kebutuhan keluarga. Kehidupan terus berjalan dan bekerja pun tetap harus jalan agar dapat mengimbangi kebutuhan hidup, mengingat pertumbuhan dan perkembangan anak-anak saya yang semakin tahun semakin besar dan keperluan keluarga memerlukan biaya besar pula. Pekerjaan mengukir juga lambat laun saya rasa semakin berkurang karena mulai muncul satu persatu pengukir-pengukir baru yang bersedia menerima harga borongan lebih murah. Namun saya tidak patah semangat dan tentunya bersyukur karena saya masih diberi kesehatan sehingga dapat digunakan untuk bekerja lebih giat lagi. 


\subsubsection{Awal perintisan usaha ukiran tahun 2000 dan perencanaan kelompok}

Perkembangan ukiran patung maupun ukiran lainnya yang ada di sekitar saya berjalan cepat. Muncul perajin-perajin baru yang ikut andil dalam pemasaran produknya di lokasi yang sama. Saat itu, saya berpikir bagaimana agar teman-teman perajin dapat berkumpul dan bersatu di dalam suatu wadah untuk menyalurkan aspirasinya dalam peningkatan hasil produk dan meningkatkan pemasaran.

Dengan keseriusan dan juga niat hati yang tulus, saya mulai bergerak dan bekerja untuk mencari langkah-langkah awal yaitu pendekatan ke masingmasing perajin supaya mereka mau diajak berkumpul. Ternyata mereka sangat tertarik bilamana ada yang berkenan untuk membantu dan mengurus hal-hal untuk mengembangkan usahanya.

Sebagai langkah awal, saya mengundang teman-teman perajin berkumpul untuk mengawali dan mendirikan sebuah kelompok dengan tujuan meningkatkan usaha dan kewirausahaan masing-masing perajin yang nantinya juga untuk kepentingan bersama kelompoknya. Pada waktu itu, saya mengundang sekitar 20 orang perajin ukir dan perajin mebel dan mereka bersepakat untuk mendirikan kelompok yang bernama Kelompok Seni Ukir Desa Mulyoharjo dan saya terpilih sebagai ketuanya. Jadi beban saya menjadi bertambah berat lagi karena harus memikirkan beberapa masalah, baik untuk keluarga sendiri maupun lingkungan masyarakat. Namun karena semua itu yang sudah menjadi keinginan dan kehendak masyarakat banyak, saya harus jalankan sesuai dengan amanat warga dan masyarakat atau kelompok lainnya.

\subsubsection{Berdirinya kelompok seni ukir dan sentra patung Mulyoharjo}

Sejak berdirinya kelompok Seni Ukir Desa Mulyoharjo pada tahun 2001, saya mencoba bergerak bagaimana cara mengembangkannya menjadi sebuah kelompok yang aktif dan dapat berguna bagi anggotanya. Ketika itu, saya mencoba untuk mencari bantuan pendanaan ke Dinas Indagkop Jepara dan saya langsung mendapatkan respon. Namun sayangnya yang ditawarkan untuk kelompok hanya sekitar sepuluh juta rupiah. Maka saya 


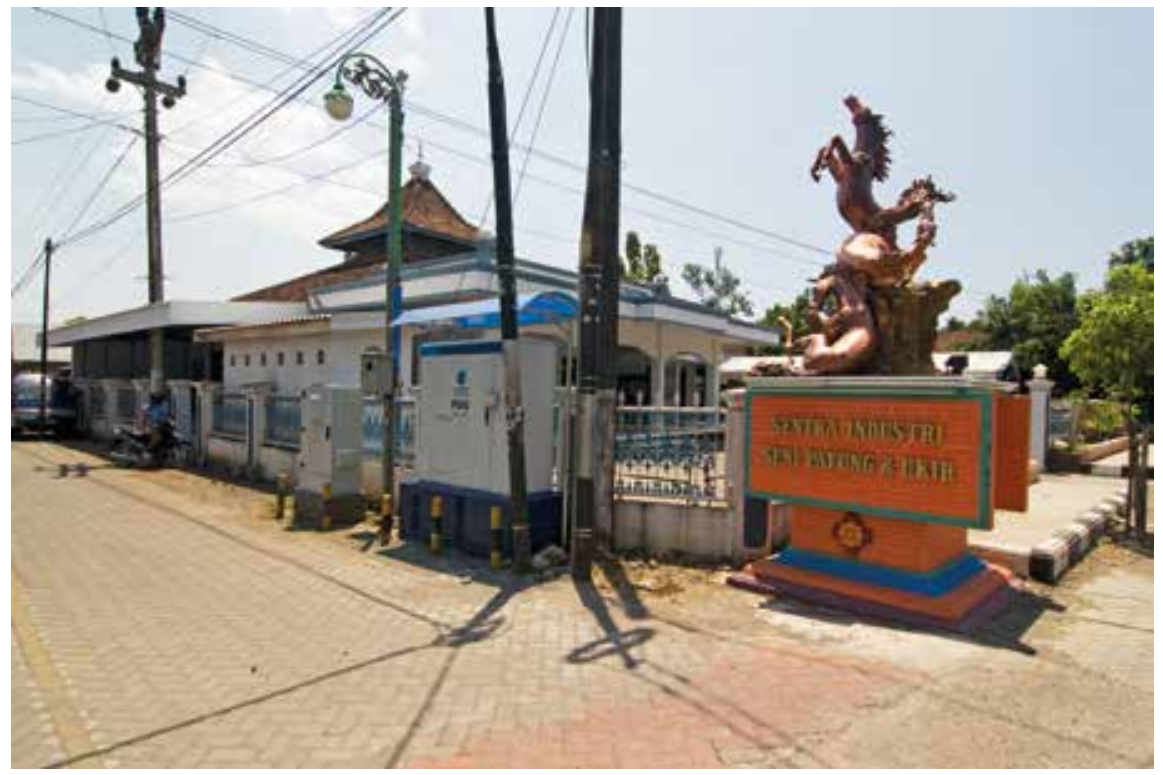

Gambar 5.4. Pintu gerbang Sentra Industri Seni Patung dan Ukir Mulyoharjo

tidak jadi mengambilnya karena belum mencukupi untuk semua anggota yang notabene mereka sudah bermodalkan lebih dari nominal itu dan juga bagaimana harus membaginya.

Kemudian pada suatu hari, saya mencoba untuk mencari informasi ke dinas Indagkop kembali yang berkaitan dengan bantuan permodalan usaha. Menurut informasi yang saya dapat, untuk mendapatkan bantuan permodalan usaha yang lebih besar baik dari instansi terkait maupun dari perbankan, saya dianjurkan untuk membuat sebuah koperasi yang berbadan hukum. Setelah mendapatkan informasi ini, saya malah menjadi ragu apakah mampu mendirikan koperasi yang berbadan hukum itu karena kami tidak memiliki latar belakang pendidikan yang berhubungan dengan koperasi.

Namun saya ingin berusaha dengan sungguh-sungguh dan ingin tahu tentang koperasi serta mau berbagi dengan teman-teman dan dinas terkait yang memiliki kemampuan berkoperasi. Ternyata hanya perlu waktu 
beberapa hari saja untuk mempelajari caranya berkoperasi. Akhirnya saya juga mendapatkan penjelasan tentang syarat-syarat mendirikan dan pembentukan koperasi yang berbadan hukum. Kemudian saya menawarkan kembali kepada teman-teman anggota kelompok seni ukir untuk membentuk sebuah lembaga koperasi formal yang berhubungan dengan permodalan dan mengajak mereka menjadi anggota koperasi.

\subsubsection{Terbentuknya Koperasi Pemuda Tunas Patria dan perkembangannya}

Akhirnya pada tahun 2002, terbentuklah koperasi yang bernama Koperasi Pemuda Tunas Patria atau disingkat dengan Kopatria yang pada waktu itu beranggotakan 25 orang dan saya terpilih menjadi ketuanya. Teman-teman anggota semuanya memberikan kepercayaan dan bertumpu pada saya untuk melaksanakan kegiatan serta maju dan mundurnya organisasi yang telah

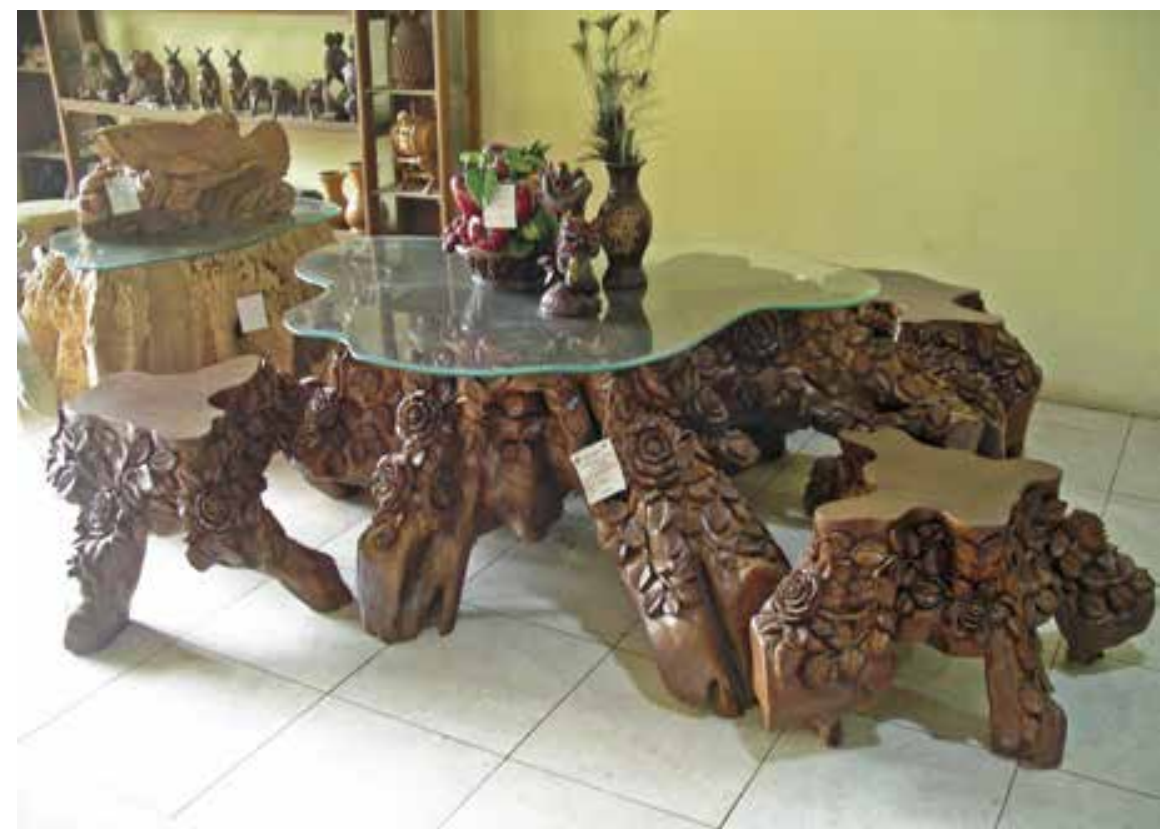

Gambar 5.5 Set meja dan kursi akar salah satu hasil karya saya 
dirintis. Kadang saya pikir-pikir, rintisan dan gagasan yang saya buat ini malah menjadikan sebuah beban tambahan bagi saya, namun semua ini pasti ada hikmahnya dan saya anggap sebagai sebuah perjuangan yang hampir sudah ada di tengah-tengah sebuah sungai yang penuh air.

Namun keinginan untuk melangkahkan kaki membuat saya berpikir seribu kali, mengingat modal awal yang dimiliki Koperasi dan Kelompok Seni Ukir tidak seberapa banyak. Selain itu tantangannya adalah bagaimana caranya modal itu dapat berkembang dan dimanfaatkan sebaik-baiknya untuk anggota. Jika saya hanya mengelola modal yang dimiliki oleh koperasi saja, sampai kapan modal itu bisa berkembang?

Lalu saya mencari tahu kepada teman-teman yang sudah berkecimpung lama di perbankan. Melalui proses panjang dan banyak liku-liku yang harus dilewati, akhirnya proposal pengajuan pinjaman kepada pihak bank dapat disetujui dengan nilai awal sebesar Rp 260 juta pada tahun 2002. Ini merupakan awal penerimaan yang cukup besar bagi Kopatria karena mendapatkan modal pinjaman dari salah satu bank ternama yaitu Bank Bukopin Cabang Semarang. Modal ini harus benar-benar dikelola koperasi dan disalurkan untuk peningkatan usaha anggota.

\subsubsection{Hasil produk kerajinan dan legalitas usaha}

Sejak perintisan usaha kerajinan ukir dari tahun 2000 sampai tahun 2005, usaha saya mengalami pasang surut. Bersumber pada keinginan supaya dapat berkembang dan mendapatkan kepercayaan dari pasar, maka saya merencanakan untuk mendaftarkannya menjadi usaha yang legal.

Rencana pendaftaran izin usaha masih menunggu waktu karena sudah ada beberapa jadwal pameran di antaranya di bulan Juni 2005 mengikuti pameran Houseware Fair di JCC Jakarta melalui BPEN (Badan Pengembangan Ekspor Nasional) dengan mendapatkan fasilitas potongan harga stand sebesar 50\%. Kemudian ada lagi fasilitas kontak dagang ke Bali dari Dinas Koperasi \& UKM Jawa Tengah pada bulan Agustus 2005 bersama rombongan UKM se-Jawa Tengah. 
Setelah jalan-jalan selama empat hari di Bali dan kegiatan lainnya, rencana yang tertunda untuk melegalkan izin usaha saya tindak lanjuti kembali dan pada saat itu tempat kantor perizinannya masih satu atap di Dinas Industri \& Perdagangan, Koperasi \& Penanaman Modal Jepara. Kebetulan banyak orang di sana yang saya kenal dan mintai tolong. Tak lama kemudian, surat izin usaha saya keluar dengan nama perusahaan Suryaputra Art, terhitung tanggal 19 Agustus 2005 sampai dengan 19 Maret 2010. Dengan adanya surat izin usaha perdagangan kerajinan dan mebel itu, saya semakin percaya diri dengan konsumen lokal maupun internasional.

\subsubsection{Menjadi pengurus ASMINDO Komda Jepara dan perkembangannya}

Pada tanggal 4 Agustus 2008, saya dikukuhkan menjadi pengurus Asmindo Komda Jepara untuk periode tahun 2008-2013 dan sebagai pengurus baru harus dapat menyusun program kerja yang sesuai dengan bidangnya. Saya dipilih dan ditunjuk masuk di bidang Kerajinan \& Desain Inovasi.

Sebagai langkah awal pengurus baru Asmindo diharapkan membuat draft atau usulan rencana kerja dan bagi semua yang namanya tercantum di pengurusan dapat menyampaikan pendapat sesuai bidangnya masingmasing. Saat itu saya menyampaikan rencana kerja untuk mengupayakan peningkatan produktivitas, kualitas, dan kreativitas produk kerajinan di Jepara yang disertai dengan inovasi-inovasi desain yang diharapkan mampu menembus pasar ekspor.

Saya diharapkan dapat bekerja sama dengan JFDC sebagai lembaga $\mathrm{R} \& \mathrm{D}$-nya Asmindo khususnya dalam hal inovasi desain sehingga dapat bermanfaat bagi anggota. Perkembangan kelembagaan Asmindo Jepara dari tahun ke tahun semakin membaik, terutama kekompakan para pengurusnya, sehingga dapat berbuat sesuatu yang berguna bagi anggota.

Agenda kegiatan Asmido Jepara sendiri setiap tahunnya yaitu memberikan data kepada anggota tentang pelaksanaan kegiatan pameran IFFINA (International Furniture \& Craft Fair Indonesia) dan pameran lainnya yang diselenggarakan di Indonesia maupun di luar negeri. IFFINA merupakan 
pameran industri mebel dan kerajinan tingkat internasional dengan konsep bisnis ke bisnis yang pertama kali diadakan di Indonesia. Pameran IFFINA ini diharapkan dapat mendorong pertumbuhan dan perkembangan industri mebel dan kerajinan di Jepara dan Indonesia pada umumnya. Indonesia juga merupakan salah satu barometer perkembangan mebel dan kerajinan di tingkat internasional. Industri mebel dan kerajinan pun merupakan industri yang telah menjadi urat nadi bagi perekonomian rakyat Indonesia dan khususnya masyarakat Jepara.

\subsubsection{Musyawarah perajin Desa Mulyoharjo}

Mulyoharjo dulu terkenal dengan ukiran macan kurung. Namun seiring perkembangan zaman, ukiran ini mulai ditinggalkan dan mereka beralih dengan ukiran patung, mebel, relief, suvenir dan kerajinan lainnya. Tahun 2003-an adalah masa kejayaan yang pernah dialami oleh perajin seakan menjadi berkah dan berpihak pada kami tanpa akhir, akan tetapi realitanya tidak dimbangi dengan berbagai kesiapan yang menyeluruh. Kami asyik memproduksi apa saja tanpa belajar sistem dan kontrol produksi yang baik dan jenis produk apa saja yang dibuat serta dapat dijual, kemudian masyarakat sekeliling ikut ramai-ramai memproduksi kerajinan yang sama. Lalu yang terjadi adalah kejayaan yang berangsur usai.

Memang masih banyak hal yang belum dilakukan oleh pengurus selama memimpin, mulai dari setiap tuntutan, usulan, dan kritik dari anggota dan bagaimana OCI dapat memberikan manfaat dan juga harapan kepada anggotanya. Tuntutan dan harapan inilah yang memerlukan kebijakan secara organisatoris untuk mengubah paradigma ke depan. Tidak cukup hanya sekedar berkumpul akan tetapi harus bekerja sama dan bahu-membahu untuk mencapai tujuan yang lebih baik.

Pada tahun 2008, handicraft dan mebel mengalami kelesuan. Pada akhirnya perajin tidak dapat memprediksikan kapan kejayaan yang dulu pernah dirasakan oleh anggota perajin akan terjadi lagi. Kami harus memikirkan situasi krisis globalisasi dan krisis finansial yang berdampak pada bisnis kami dan bagaimana harus bertahan untuk menghadapi gempuran dan persaingan yang sangat ketat. Kami tidak mungkin berjalan sendiri-sendiri namun harus 
bersatu padu untuk menyamakan persepsi dan visi untuk membangun usaha dan mengembangkan industri kerajinan kayu Desa Mulyoharjo agar lebih solid. Untuk ke depannya, semoga arahan dan tujuan kerajinan patung, mebel, relief, dan suvenir Desa Mulyoharjo dapat berkesinambungan.

\subsubsection{Menjadi Pengurus APKJ}

Sebelum terbentuknya Asosiasi Pengrajin Kecil Jepara (APKJ) pada tanggal 23 Desember 2008, dulu ada wacana di dalam musyawarah perumusan nama yaitu Asosiasi Pengrajin Jepara (APJ) yang bertempat di gedung JTTC yang difasilitasi oleh CIFOR. Waktu itu saya bergabung dengan kelompok dan ikut merumuskan pembentukan asosiasi perajin dengan masingmasing kelompok untuk dapat membuat draft visi, misi, maksud tujuan, dan langkah-langkah asosiasi yang didirikan. Seiring perkembangan dan keseriusan dari teman-teman perajin kami membentuk asosiasi yang nantinya akan berguna sebagai wadah dan inspirasi para perajin kacil itu sendiri.

Karena industri mebel dan kerajinan tidak terpisahkan dari kehidupan masyarakat Jepara, maka perlu adanya pemberdayaan dan pengembangan yang lebih serius. Akhirnya dilaksanakan deklarasi APKJ pada tanggal 9 Juni 2009 yang bertempat di gedung JTTC Rengging Pecangaan Jepara. Deklarasi kepengurusan baru yang terpilih diharapkan dapat memberikan manfaat dan programnya ke depan diharapkan dapat berguna bagi anggotanya. Pada saat itu, saya mengucapkan selamat dan semoga sukses kepada pengurus khususnya tim 8 yang dapat mengantarkan hingga terbentuknya APKJ.

Pada hari Rabu, tanggal 11 Juli 2012, APKJ melaksanakan Musyawarah Daerah guna melaporkan kinerja kepengurusan selama tiga tahun, yang bertempat di gedung JTTC Rengging Pecangaan Jepara. Musyawarah Daerah APKJ II dihadiri oleh Dinas Kehutanan Kab. Jepara, Dinas Indag Kab. Jepara, CIFOR dan Anggota APKJ. Selain menyelenggarakan Musda dan re-organisasi pengurus untuk periode tahun 2012-2017 dan kami mempertemukan anggota APKJ untuk menilai dan memberikan masukan kepada pengurus 2009-2012. 


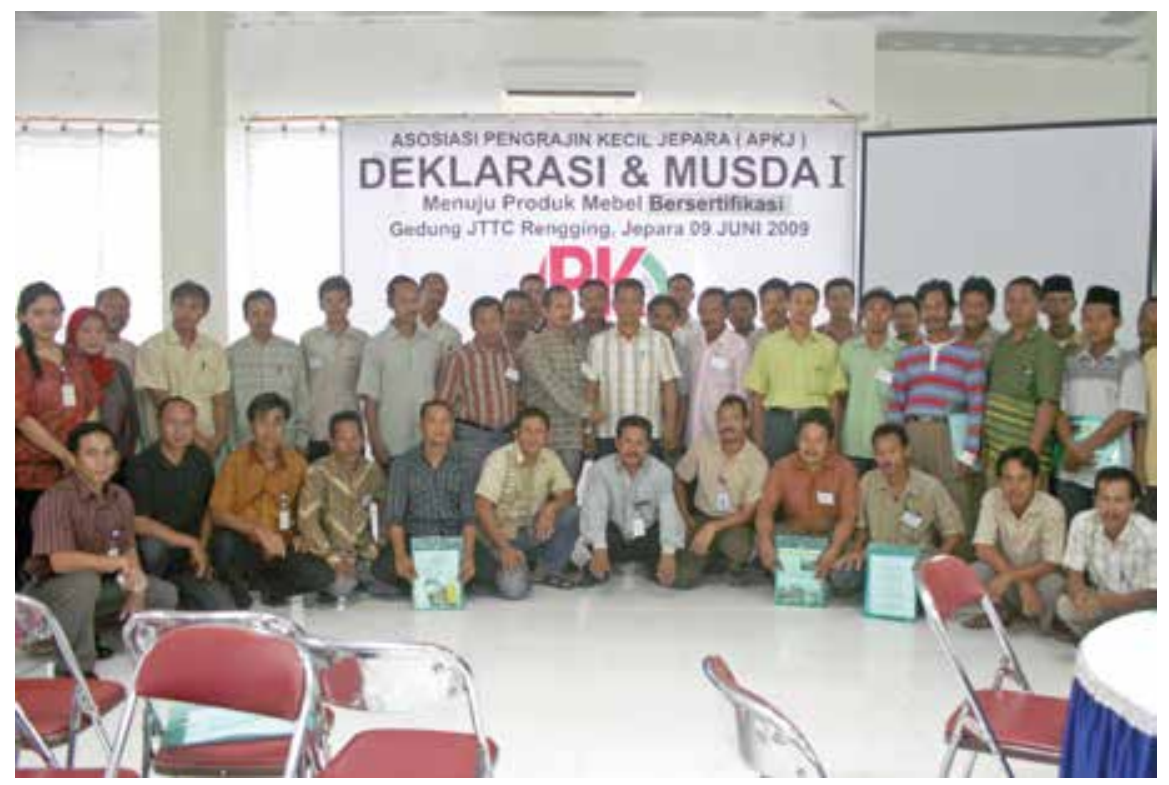

Gambar 5.6. Keterlibatan saya dalam deklarasi dan Musda I APKJ

MUSDA dilaksanakan berlandaskan Anggaran Dasar dan Anggaran Rumah Tangga (AD/ART) APKJ pada AD Bab. II pasal 6 tentang musyawarah daerah dan ART Bab. IV pasal 15 tentang musyawarah daerah yang mengacu pada keputusan rapat Dewan Pengurus. Ketika Musda dilaksanakan terlihat banyak hal yang perlu untuk mendapatkan perhatian khusus, di mana AD/ART APKJ sangat memerlukan perubahan mengingat perkembangan dan keberlangsungan APKJ di masa depan. Di antaranya, nama Asosiasi Pengrajin Kecil Jepara diubah menjadi Asosiasi Perajin Kayu Jepara dan masa jabatan kepengurusan diubah dari tiga tahun menjadi lima tahun dan tentunya masih banyak pasal per pasal yang disesuaikan dengan perkembangan.

Setelah laporan pertanggungjawaban pengurus periode 2009-2012 dapat diterima dan disahkan oleh Musda dan telah dinyatakan demisioner, maka kepengurusan APKJ untuk masa bakti 2012-2017 dapat ditetapkan dan 
mendapatkan pengesahan dari Musyawarah Daerah. Keputusan Musyawarah Daerah APKJ adalah:

1. Menetapkan tata tertib Musda II APKJ

2. Menetapkan perubahan AD/ART APKJ

3. Menetapkan program Kerja

4. Pengesahan laporan pengurus periode 2009-2012

5. Menetapkan pengurus untuk masa bakti tahun 2012-2017

\subsection{Penutup}

Demikianlah kisah perjalanan hidup seorang tukang ukir dan organisasinya. Tentu banyak kekurangan dan kesalahan dalam penulisan cerita, terima kasih dan mudah-mudahan bermanfaat. CIFOR sebagai lembaga riset industri kerajinan kayu di Jepara berperan sebagai pendamping dan mediator asosiasi APKJ, yang lahir atas prakarsa CIFOR. Tujuannya adalah agar para perajin mebel dan ukir di Jepara dapat terwadahi di dalam asosiasi atau lembaga.

Karena Jepara merupakan daerah yang paling banyak membutuhkan bahan kayu dan sebagian besar kayu yang didatangkan dari luar Jepara, sehingga ketergantungan ini menciptakan kerawanan untuk keberlangsungan usaha perajin. Akibatnya, perajin tidak dapat mengendalikan harga karena mutu dari bahan kayu yang sangat rendah. Namun demikian, perajin tetap memproduksi mebel dengan kualitas rendah agar dapat menghidupi keberlangsungan usahanya. Tentu saja tindakan perajin ini tidak dapat berlangsung cukup lama, sehingga banyak yang mengalami tutup usahanya karena mebel yang diproduksi tidak laku dijual.

Untuk menyikapi hal tersebut, perlu adanya pendampingan dari CIFOR melalui asosiasi APKJ, khususnya dalam mengatasi berbagai masalah yang dihadapi oleh perajin dan bagaimana mempertahankan keberlangsungan usaha mebel mereka. Pelatihan-pelatihan yang berhubungan dengan industri mebel juga perlu terus dilakukan, terutama peningkatan sumber daya manusia yang berkualitas. Selain itu, untuk meningkatkan mutu dan penghasilan serta kehidupan para perajin mebel Jepara perlu adanya efisiensi rantai nilai mebel atau FVC. Pada dasarnya, rantai nilai akan menentukan keberhasilan yang strategis dan terarah. 
Oleh karena itu, kegiatan-kegiatan CIFOR di Jepara sangat diperlukan, tidak hanya bagi perajin mebel saja tetapi juga sangat berguna bagi pemerintah Kabupaten Jepara. Kegiatan dan tugas CIFOR selama di Jepara untuk mendampingi APKJ dan perajinnya akan membawa manfaat dan dampak positif, mengingat masih banyaknya permasalahan perajin mebel yang harus diselesaikan, seperti persyaratan legalitas kayu atau SVLK yang selama ini menjadi momok bersama.

Dampak dan pengaruh CIFOR pada usaha kerajinan kayu di Jepara, khususnya di bidang handicraft yang saya jalankan tentunya tidak menjadi persoalan yang berarti. Keberadaan CIFOR di Jepara utamanya hanya sebagai riset kayu log jati dan industri mebel, sedangkan bahan baku yang saya gunakan adalah akar kayu jati dan sebagian kayu trembesi, sono, dan mahoni. Jika memungkinkan CIFOR dapat bekerja lebih mendalam lagi dalam kegiatannya agar semua jenis kayu yang ada di Jepara, khususnya di Sentra Patung Mulyoharjo, dapat diagendakan dalam penelitian atau risetnya. Di sana terdapat perajin handicraft yang berjumlah sekitar 130 perajin yang umumnya menggunakan kayu jati, sono, mahoni, trembesi/ meh, nangka, mangga, jengkol, pete, dan masih banyak lagi jenis kayu lainnya. 


\section{Bab 6.}

Pengembangan industri mebel Jepara melalui proyek Furniture Value Chain

Oleh: Adi Nugroho Prasastyanto

\subsection{Perjalanan sebagai PNS di Kabupaten Jepara}

Sejak kecil saya bercita-cita untuk bisa menjadi orang yang paling sedikit, bisa berguna untuk orang lain. Media untuk mewujudkan keinginan ini dalam benak saya saat itu adalah dengan menjadi Pegawai Negeri Sipil (PNS). Mengapa menjadi PNS? Mungkin ini dilhami oleh orang-orang di sekitar saya, karena saya lahir dalam keluarga PNS. Ayah saya seorang PNS di Departemen Pendidikan dan Kebudayaan (saat ini berubah menjadi Kementerian Pendidikan Nasional) dan ibu saya seorang PNS yang berprofesi sebagai guru bahasa Inggris di Sekolah Menengah Pertama (SMP). Saya lahir di Semarang pada bulan Juli 1961, tetapi saya menghabiskan masa kecil saya di Jakarta karena ayah saya pindah tugas dari Kantor Wilayah Departemen Pendidikan dan Kebudayaan Jawa Tengah ke kantor pusat di Jakarta dan ibu saya juga pindah mengajar dari Semarang ke salah satu sekolah negeri di Jakarta.

Masa kecil sejak saya sekolah di Taman Kanak-Kanak (TK) hingga Sekolah Menengah Atas (SMA) saya habiskan di Jakarta. Untuk menyelesaikan pendidikan saya, hampir tidak ada kesulitan yang berarti. Pada saat saya duduk di Sekolah Dasar, saya termasuk murid yang dapat menyelesaikan dengan nilai yang cukup baik. Hal ini karena orang tua saya yang cukup berpendidikan sehingga saya dapat bertanya pada kedua orang tua apabila 


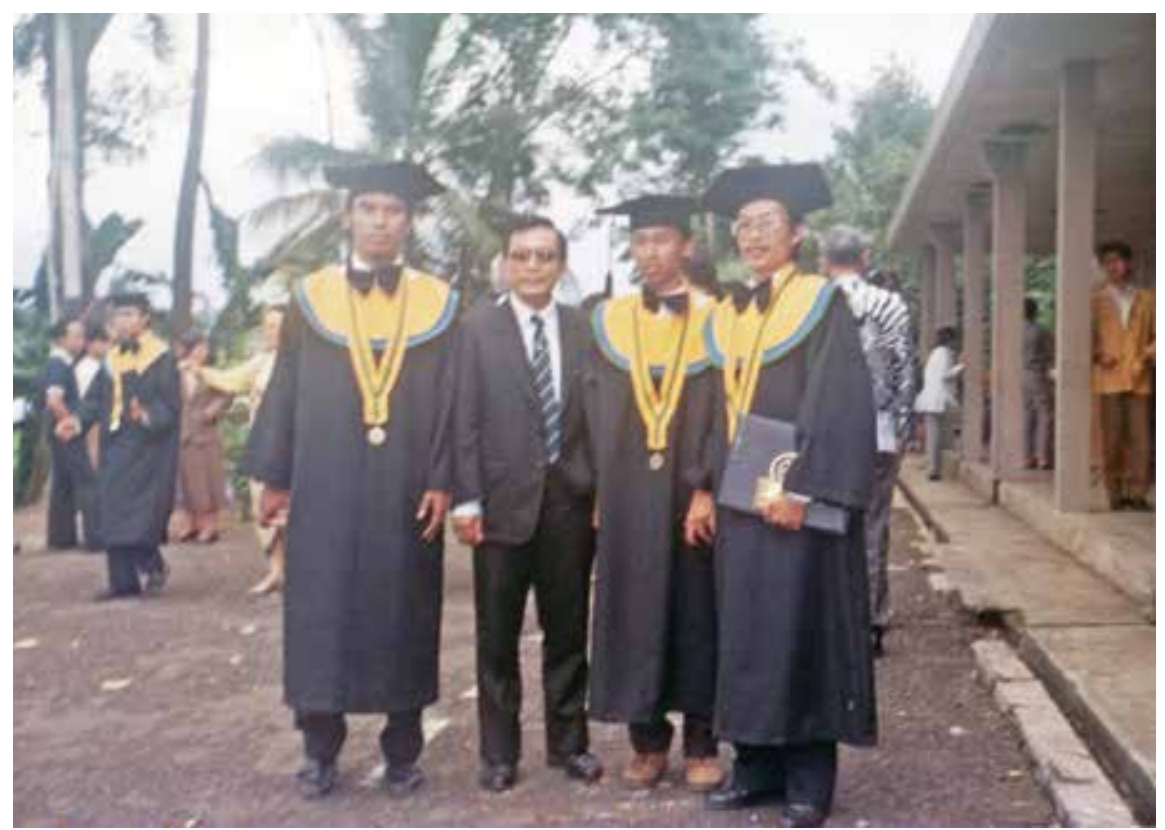

Gambar 6.1. Berfoto bersama Dekan Fakultas Pertanian Universitas Jenderal Soedirman setelah wisuda

ada pelajaran yang tidak dapat saya mengerti di sekolah. Demikian pula pada saat SMP dan SMA, yang dapat saya lalui dengan baik tanpa ada hambatan yang berarti.

Saya lulus SMA pada tahun 1980 dari sebuah sekolah yang cukup favorit di Jakarta pada saat itu. Setelah lulus SMA tahun 1981, saya melanjutkan pendidikan ke Fakultas Pertanian Universitas Jenderal Soedirman di Purwokerto. Saya berpikir pada saat itu nantinya saya akan bekerja pada sebuah lembaga pemerintah yang ada kaitannya dengan pertanian. Namun prakiraan ini belakangan saya ketahui tidak sepenuhnya tepat, walaupun akhirnya saya mengabdikan diri sebagai Pegawai Negeri Sipil.

Setelah tamat perguruan tinggi tahun 1987, saya bekerja selama kurang lebih empat tahun pada sebuah perusahaan swasta di Jakarta. Akan tetapi ketika 
kesempatan datang, karena sejak kecil bercita-cita bekerja sebagai pegawai pemerintah, saya mendaftar sebagai PNS di lingkungan Departemen Dalam Negeri. Setelah dinyatakan lulus ujian seleksi ternyata saya di tempatkan di daerah otonom tingkat II Kabupaten Jepara (pada saat itu sebutan untuk daerah kabupaten adalah Kabupaten Daerah Tingkat II), sehingga kalau kita menyebut Jepara pada waktu itu adalah Kabupaten Dati II Jepara dan di sinilah awal keterlibatan saya di Kabupaten Jepara sebagai abdi negara yang ditugaskan di daerah.

Saya pertama menginjakkan kaki di Kabupaten Jepara ketika mulai bekerja sebagai PNS pada tahun 1991, tepatnya pada bulan Maret. Pada saat itu status saya adalah sebagai pegawai Departemen Dalam Negeri yang diperbantukan di daerah otonom Tingkat II.

Sebelum bekerja di Kabupaten Jepara, saya sudah mengenalnya karena sudah beberapa kali berkunjung, sekedar untuk berwisata. Saat itu yang saya ketahui dari Kabupaten Jepara adalah kerajinan ukiran kayunya yang terkenal terutama kursi, lemari, dan tempat tidur yang mempunyai ciri khas berbeda dari produk daerah lain di Indonesia. Ornamen ukirannya khas dan dibuat oleh orang-orang yang mempunyai keterampilan tinggi.

Ketika saya pertama kali menginjakkan kaki di Kabupaten Jepara, yang terlihat adalah jajaran toko mebel yang memajang aneka mebel dari kayu di sepanjang jalan, dari mulai masuk daerah di depan Kecamatan Tahunan sampai masuk ke Kota Jepara. Terlihat di sepanjang jalan itu ruang pajang yang dipenuhi hasil kerajinan mebel yang bagus. Sepintas berkesan bahwa para pelaku industri kerajinan mebel ukir di Kabupaten Jepara sepertinya hidup berkecukupan, bahkan terbilang mewah.

Belakangan saya ketahui ternyata banyak persoalan yang harus diselesaikan oleh para pelaku industri kerajinan mebel ukir di kota ini. Para perajin, pengusaha/eksportir dan pelaku yang terkait dengan industri yang menjadi andalan di kabupaten ini perlu bekerja sama supaya masing-masing pelaku pada rantai nilai industri ini mendapat keuntungan yang adil sesuai peran dan fungsinya masing-masing. Inilah barangkali salah satu tugas pemerintah 
daerah dalam hal ini dinas yang membawahi perindustrian, untuk memikirkan bersama dengan para pihak yang terkait, mencari solusi untuk memajukan industri mebel yang merupakan tulang punggung perekonomian masyarakat Jepara.

Ketika pertama bekerja di Kabupaten Jepara, Bupati Jepara saat itu menempatkan saya di Badan Perencanaan Pembangunan Daerah (Bappeda). Dengan membawa surat penugasan dari Sekretaris Daerah saya melapor kepada Kepala Bappeda. Waktu itu, orang dengan ijazah sarjana strata 1 di pemerintah daerah tingkat kabupaten belum sebanyak sekarang, saya pikir mungkin sama kondisinya antara Jepara dengan daerah-daerah lain di seluruh Indonesia. Kalau di Jawa saja yang dekat dengan pemerintahan pusat kondisinya seperti itu, mungkin di luar Jawa lebih sedikit lagi orang yang berijazah S1 yang mau mengabdikan dirinya bekerja di tingkat kabupaten.

Pada awal bekerja di Bappeda, saya ditempatkan di Bidang Fisik dan Prasarana. Sebetulnya penempatan ini agak kurang pas dengan pendidikan S1 saya. Mungkin karena pejabat Kepala Bidang yang kepangkatannya sama dengan saya hanya di bidang tersebut. Sebab dalam aturan kepangkatan PNS, seseorang dengan ijazah S1 langsung mendapat pangkat dengan golongan ruang IIIa, sementara hampir semua Kepala Bidang di Bappeda saat itu pangkatnya belum mencapai golongan ruang IIIa.

Karena sudah menjadi tekad saya untuk menjadi seorang PNS, maka penugasan itu saya jalani dengan senang hati walaupun tugas-tugas yang saya laksanakan secara teknis memang tidak terlalu berhubungan dengan pendidikan saya. Pada saat itu saya bertugas sebagai staf di Seksi Penghijauan dan Lingkungan Hidup. Meskipun secara teknis tugas-tugas kedinasan yang saya jalani waktu itu tidak terlalu berhubungan dengan bidang keahlian pertanian, pengalaman-pengalaman saya selama kuliah sangat membantu saya, terutama dalam melakukan analisis dan pemecahan masalah yang saya hadapi dalam tugas sehari-hari.

Selama bekerja di Bappeda Kabupaten Jepara, saya berpindah-pindah di berbagai bidang. Dalam struktur organisasi Bappeda Kabupaten Jepara pada 
saat itu, ada Kepala Bappeda, Sekretariat, dan empat bidang yaitu: Bidang Fisik dan Prasarana, Bidang Ekonomi, Bidang Pendataan dan Laporan, serta Bidang Sosial Budaya. Penempatan saya pada bidang-bidang yang berbeda ini akhirnya saya sadari merupakan hal yang bermanfaat, sehingga saya dapat mempunyai gambaran yang utuh tentang bagaimana sebuah lembaga perencanaan di daerah kabupaten seharusnya bekerja dalam melaksanakan tugas dan fungsinya.

Pada Tahun 1999, saya mengikuti seleksi yang diselenggarakan oleh Departemen Dalam Negeri (sekarang Kementerian Dalam Negeri) untuk mengikuti pendidikan strata 2. Saat itu saya dinyatakan lulus dan berkesempatan mengikuti pendidikan di Magister Ekonomika Pembangunan (MEP) Universitas Gajah Mada dan saya mengambil jurusan Keuangan Daerah. Pendidikan ini saya jalani selama lebih kurang 18 bulan. Setelah lulus dari MEP UGM, saya ditempatkan di Kantor Pengolahan Data Elektronik, kemudian dimutasi ke Badan Kepegawaian Daerah (BKD) sebagai Kepala Bidang Perencanaan dan Pengembangan Pegawai. Sekali lagi, tugas-tugasnya di luar keahlian yang saya pelajari selama mengikuti pendidikan tinggi S1 dan S2.

Kemudian pada tahun 2007, tepatnya bulan Juli, saya dimutasikan ke Bidang Ekonomi Bappeda sebagai Kepala Bidang Ekonomi. Barangkali pengalaman-pengalaman selama saya menjalankan tugas inilah yang sedikit banyak berhubungan dengan permasalahan seputar industri di Kabupaten Jepara, yang di dalamnya ada industri kerajinan mebel ukir yang merupakan tulang punggung perekonomian daerah.

Pada tahun 2010, saya mendapatkan beasiswa dari Netherlands Education Support Office (NESO) yang bekerja sama dengan Bappenas (Badan Perencanaan Pembangunan Nasional) menyelenggarakan Program Pendidikan Regional Economic Development Support (REDS) Lingkage, yang dilaksanakan di Indonesia (di Universitas Gadjah Mada) selama dua minggu dan di Belanda yaitu di Institute For Housing and Urban Development Studies (IHS) Erasmus University Rotterdam selama tiga minggu. Pengalaman mengikuti pendidikan di Belanda sangat berguna 


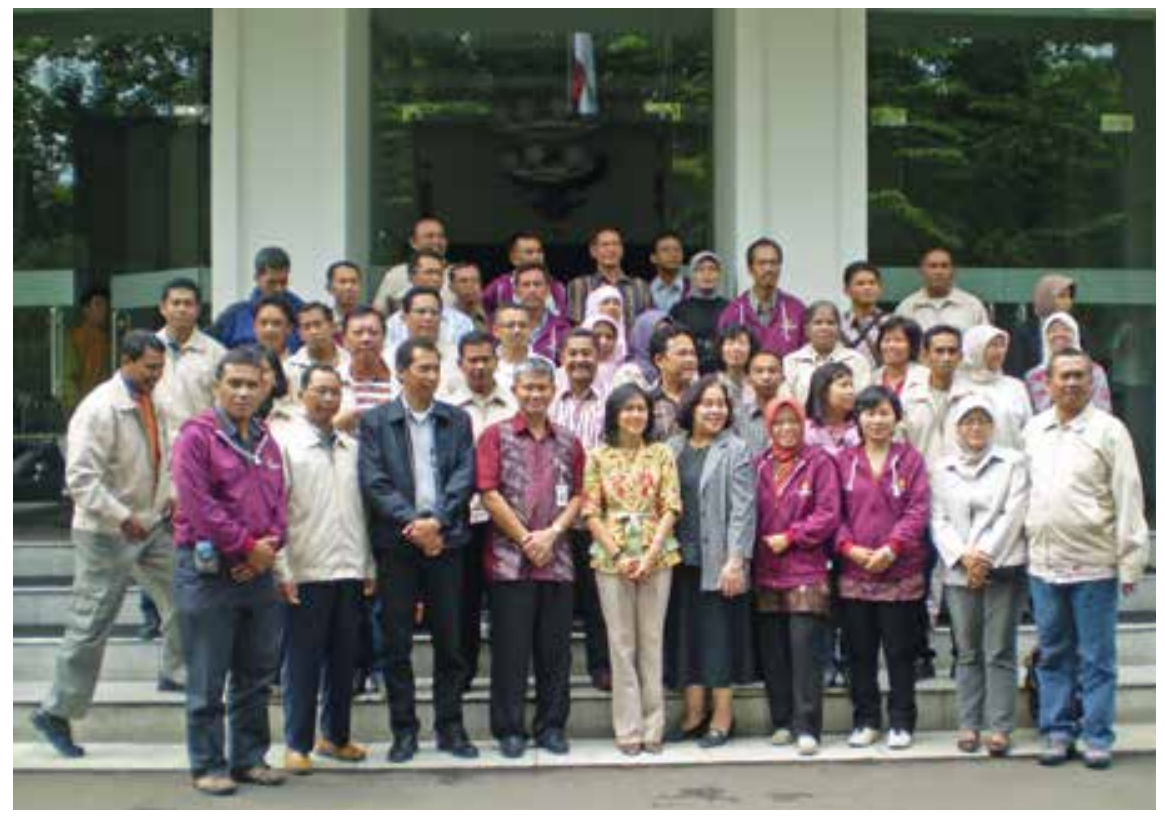

Gambar 6.2. Berfoto bersama pejabat Bappenas dan peserta Program Pendidikan REDS Lingkage Indonesia-Belanda sebelum keberangkatan ke Rotterdam, Belanda

sekali bagi saya untuk menjalankan tugas-tugas sebagai perencana di bidang ekonomi. Menurut pendapat saya, berdasarkan pengalaman yang saya pelajari dan lihat selama mengikuti pendidikan di Belanda, kata kunci keberhasilan para pelaku usaha di Negeri Kincir Angin tersebut adalah pada kerja sama dan daya saing. Barangkali ini merupakan dua hal yang kurang dimiliki oleh para pelaku usaha di Indonesia, utamanya usaha berskala kecil.

Tugas-tugas di bidang ekonomi di Bappeda Jeparalah yang akhirnya membawa saya untuk turut serta bersama pihak-pihak terkait, berusaha mencari solusi untuk kemajuan salah satu bidang usaha di Kabupaten Jepara yang sumbangannya cukup besar bagi Produk Domestik Regional Bruto (PDRB) Kabupaten Jepara yaitu industri kerajinan mebel ukir. 
Seperti kita ketahui bersama, perjalanan perkembangan industri kerajinan mebel ukir Kabupaten Jepara mengalami fase pasang surut. Booming pernah terjadi karena dampak situasi perekonomian pada saat itu, namun surut kembali akibat perilaku pelaku-pelaku usaha yang mendadak terjun pada industri tersebut yang kurang profesional sehingga kurang dapat mempertahankan kualitas produk. Sekarang mereka berusaha untuk merangkak naik lagi dan pemerintah Kabupaten Jepara terus berupaya untuk memajukan usaha kerajinan mebel ukir yang memang menjadi usaha yang menyerap tenaga kerja cukup banyak dan dapat dikatakan merupakan tulang punggung perekonomian masyarakat Jepara.

Sudah banyak upaya yang dilakukan untuk memajukan industri kerajinan mebel ukir ini, seperti menjaga kontinuitas pasokan bahan baku, pembinaan kepada perajin untuk meningkatkan kualitas produk, sampai dengan upaya menembus pasar luar negeri melalui keikutsertaan pameran di dalam dan luar negeri.

\subsection{Keterlibatan dalam Proyek Penelitian Rantai Nilai Industri Mebel yang dilaksanakan oleh CIFOR}

Pada tahun 2007, sebagai Kepala Bidang Ekonomi di Bappeda, saya menghadiri undangan lokakarya penelitian tentang peningkatan kesejahteraan pelaku industri mebel di Jepara. Lokakarya ini dilaksanakan oleh CIFOR bekerja sama dengan lembaga penelitian pertanian untuk pembangunan dari Perancis yaitu CIRAD (Centre de coopération internationale en recherche agronomique pour le développement), Fakultas Kehutanan Universitas Gadjah Mada, dan Pemerintah Kabupaten Jepara. Melalui perbincangan dengan teman-teman dari CIFOR, saya mendapat informasi bahwa CIFOR sedang merancang untuk melakukan penelitian kaji tindak tentang mebel (Action Research Furniture Value Chain). Kepada teman-teman dari CIFOR, saya katakan waktu itu bahwa saya mendukung lembaga apa pun yang akan mengadakan kegiatan yang menurut saya akan membawa dampak positif bagi perkembangan industri mebel di Kabupaten Jepara. 
Pada akhir tahun 2008, saya mendapat kabar bahwa CIFOR dengan pendanaan dari ACIAR (Australian Centre for International Agricultural Research) akan melakukan penelitian kaji tindak mengenai industri mebel di Jepara. Lalu sekitar awal tahun 2009, saya bersama-sama dengan satuan kerja yang terkait dengan industri mebel yaitu Bagian Perekonomian Setda Jepara dan Dinas Perindustrian dan Perdagangan diundang ke Kantor Pusat CIFOR di Bogor untuk melakukan lokakarya tentang aktivitas yang dibutuhkan untuk melaksanakan FCV di Kabupaten Jepara. Dari Jepara, kami berangkat bersama-sama tidak hanya dari Bagian Perekonomian dan Dinas Industri dan Perdagangan, tetapi juga dengan 2 orang wakil dari perajin kecil di Kabupaten Jepara, seorang dari Jepara Furniture Desain Centre (JFDC) dan 2 orang wakil dari Asosiasi Pengusaha Mebel Indonesia Jepara.

Menurut pendapat saya pada saat itu, CIFOR memang cukup tepat mengundang orang-orang dari Pemkab Jepara, JFDC, pelaku industri mebel baik yang cukup besar (Asmindo) maupun perajin kecil yang mewakili pelaku industri yang jumlahnya memang cukup besar (pada waktu itu perajin kecil belum mempunyai asosiasi). Belakangan, salah satu hasil dari kegiatan FCV di Jepara adalah terbentuknya wadah bagi perajin kecil untuk berorganisasi di mana mereka dapat berpikir bersama-sama untuk memecahkan permasalahan yang mereka temui dalam menjalankan usahanya dan organisasi tersebut diberi nama APKJ (Asosiasi Pengrajin Kecil Jepara).

Pada akhir lokakarya di Bogor tersebut, dilakukan penandatanganan Memorandum of Understanding (MOU) antara CIFOR dengan Pemkab Jepara tentang FVC Project. Dengan adanya MOU tersebut, maka Pemerintah Kabupaten Jepara setuju dan mendukung sepenuhnya kegiatan FVC di wilayah Kabupaten Jepara. Kesan saya ketika pertama kali datang ke kantor pusat CIFOR di Bogor adalah lembaga ini merupakan lembaga yang cukup bagus, terlihat dari sarana dan prasarana yang ada di areal kantor tersebut. Belakangan baru saya ketahui ternyata CIFOR merupakan lembaga yang didirikan oleh negara-negara yang di wilayahnya mempunyai areal hutan dan bermarkas di Bogor. 
Di areal kantor pusat CIFOR ada hutan yang mungkin merupakan miniatur hutan yang dapat berfungsi sebagai obyek penelitian. Dengan demikian dalam benak saya pada saat itu, barangkali CIFOR memutuskan untuk melaksanakan proyek FVC di Jepara karena kota ini merupakan pusat mebel di Jawa Tengah dan mungkin bukan hanya lingkup Jawa Tengah saja, melainkan nasional.

Sebelum CIFOR melaksanakan aktivitasnya, industri mebel di Kabupaten Jepara mengalami pasang surut. Sebelum tahun 1998, industri mebel berbahan baku kayu di Jepara belum terlalu maju, meskipun industri ini banyak menyerap tenaga kerja dan kontribusinya cukup besar bagi Produk Domestik Regional Bruto (PDRB) Kabupaten Jepara maju. Meskipun sebenarnya perkembangan pesat industri ini sudah mulai tampak sejak tahun 1991, baru sekitar tahun 1998-2000 terlihat perkembangan pesat dari industri ini.

Perkembangan selama tahun tersebut sangat dipengaruhi oleh krisis ekonomi yang terjadi di Indonesia. Selama krisis ekonomi ini, nilai tukar rupiah terhadap dolar terdepresiasi. Akibatnya, banyak daerah di Indonesia yang terpukul karena krisis yang tadinya berupa krisis moneter berkembang menjadi krisis ekonomi. Inflasi pada saat itu menembus angka 2 digit dan banyak terjadi pemutusan hubungan kerja (PHK) terutama pada industriindustri yang berbahan baku impor.

Kondisi sebaliknya terjadi di Kabupaten Jepara. Industri kerajinan mebel ukir, terutama yang memasarkan produknya ke luar negeri berkembang pesat. Karena hal ini disebabkan dengan adanya depresiasi nilai tukar rupiah terhadap dolar. Maka untuk jumlah barang yang sama dan harga yang sama, produsen mebel mendapatkan keuntungan yang lebih besar, karena produk mereka dibayar dengan dolar, sementara untuk biaya produksi (membayar pegawai, membeli bahan baku, dan sebagainya), para produsen mebel membayarnya dengan rupiah. Karena itu, dapat dikatakan bahwa Kabupaten Jepara justru mendapat hikmah dari krisis ekonomi secara nasional pada saat itu. 
Namun demikian, keadaan ini membawa dampak pada pengurasan bahan baku industri tersebut yaitu kayu. Terlebih lagi selama krisis tersebut terjadi peralihan kekuasaan dari orde baru ke orde reformasi, di mana terjadi kekacauan politik tidak hanya terjadi di pusat tetapi juga di daerah sehingga pengawasannya kurang. Situasi ini memberi peluang pembalakan kayu secara liar dan para penebang liar ini menjual kayunya kepada produsen mebel dengan harga murah. Akibat pembalakan liar secara besar-besaran ini, kemudian membawa dampak negatif bagi perkembangan industri kerajinan mebel ukir, terutama dari sisi pemenuhan bahan baku. Industri mebel ukir di Kabupaten Jepara terancam kekurangan bahan baku yang sampai sekarang. Saat ini, kebutuhan bahan baku kayu untuk industri mebel di sini masih harus didatangkan dari luar wilayah Jepara.

Dari tahun 2001 sampai dengan 2008, industri mebel ukir di Kabupaten Jepara mengalami penurunan. Penyebabnya adalah merosotnya kepercayaan pasar akibat banyaknya pelaku industri dadakan yang menjalankan usahanya secara tidak profesional. Namun sekarang, industri ini mulai berkembang kembali.

Kedatangan CIFOR dengan aktivitasnya di Jepara menurut saya cukup tepat dan aktivitas-aktivitas yang dilaksanakan dalam proyek FVC ini cukup menjanjikan untuk mendongkrak perkembangan industri kerajinan mebel ukir di Jepara.

Karena banyak industri mebel berbahan baku kayu di Kabupaten Jepara, maka diperlukan upaya-upaya agar dalam memproduksi mebelnya, perajin di Jepara tidak hanya bisa menggunakan bahan baku saja, tetapi berusaha untuk menjaga kontinuitas pasokan bahan baku. Upaya ini disertani penanaman pohon, menanam juga berarti menjaga keberlangsungan hutan di Kabupaten Jepara.

Salah satu hasil dari kegiatan CIFOR di Kabupaten Jepara yang cukup penting menurut pendapat saya adalah lahirnya organisasi para perajin untuk bersama-sama memikirkan kemajuan usahanya. Barangkali ide pembentukan suatu wadah organisasi adalah karena saat itu mereka merasa 
ada kepentingan-kepentingan yang belum dapat tertampung oleh organisasiorganisasi yang selama ini ada di Jepara.

Seingat saya waktu kami berkumpul di Bogor pada malam hari setelah makan malam, kami terlibat diskusi yang cukup intens dengan temanteman dari Jepara yang hadir waktu itu. Pada saat itu, saya termasuk orang yang menyarankan agar teman-teman perajin bergabung saja dengan organisasi yang sudah ada untuk mencoba meningkatkan usahanya. Akan tetapi, mereka memandang akan lebih baik lagi jika para perajin di Jepara mempunyai wadah sendiri. Menurut pendapat saya tidak masalah jika memang mereka ingin membentuk organisasi sendiri untuk memperjuangkan kepentingan-kepentingannya. Saya sarankan juga agar setelah organisasi terbentuk, mereka bekerja sama dengan organisasi sejenis dengan bidang garap yang kurang lebih sama yang sudah lebih dulu ada. Saya yakin bahwa dengan bersinergi dengan organisasi yang lebih besar, mereka akan dapat belajar dan ini merupakan pengalaman yang berharga untuk mengembangkan diri.

Ide dari teman-teman perajin tersebut kemudian diteruskan kepada rekanrekan dari CIFOR dan setelah melalui diskusi dan persiapan yang cukup panjang, berdirilah organisasi perajin kecil dengan nama APKJ (Asosiasi Pengrajin Kecil Jepara). Melihat dari namanya, sepintas orang akan mengira bahwa APKJ adalah sebuah organisasi yang menghimpun perajin di Kabupaten Jepara dengan tidak memandang bahan baku yang digunakan. Namun saat ini yang menjadi bidang garap APKJ adalah perajin yang memproduksi barangnya dengan bahan baku kayu, terutama perajin mebel.

Saat ini aktivitas organisasi tersebut mungkin masih banyak didampingi oleh teman-teman dari CIFOR. Namun ke depan saya berharap agar temanteman perajin berusaha terus menerus untuk mengasah kemampuannya, sehingga bisa melakukan upaya-upaya untuk mencari pemecahan atas masalah-masalah yang dijumpai dalam menjalankan usahanya. Kemandirian ini sangat penting karena CIFOR tidak akan selamanya ada di Jepara; suatu saat apabila proyek FVC sudah selesai, maka CIFOR akan meninggalkan Jepara. Karena itu segala sesuatu yang sudah dirintis bersama-sama, termasuk 
lahirnya APKJ, diharapkan akan dapat menjadi aset sumber daya manusia daerah yang mampu memajukan industri mebel ukir di Kabupaten Jepara.

Selama saya terlibat mengikuti berbagai kegiatan CIFOR, saya ketahui bahwa CIFOR berupaya untuk mengangkat usaha kecil (pelaku industri mebel skala kecil) di Kabupaten Jepara melalui empat pendekatan/strategi utama, yaitu pertama, mendekatkan para pelaku industri mebel berskala kecil dengan sumber bahan baku seperti pedagang kayu dan petani hutan. Dengan membangun jaringan dengan petani hutan dan pedagang bahan baku, diharapkan akan dapat menjamin kelangsungan pasokan bahan baku dengan harga yang wajar dan rasional untuk menjalankan usahanya. Ke dua, dengan berupaya meningkatkan kapasitas para perajin dalam mengelola usahanya baik dari sisi produksi maupun pemasaran, di antaranya dengan memfasilitasi keikutsertaan dalam pameran-pameran dan menggunakan teknologi informasi untuk memasarkan produknya. Ke tiga, dengan membantu perajin untuk dapat menghasilkan produk-produk mebel yang bersertifikat yang akhir-akhir ini menjadi persyaratan mutlak para pembeli terutama dari Amerika dan Eropa. Pendekatan ke empat adalah dengan membantu para perajin untuk dapat maju secara bersama-sama, berpikir bersama-sama dalam upaya memecahkan permasalahan dalam menjalankan industri mebel. Kegiatan ini dilakukan dengan memfasilitasi para perajin kecil untuk berkelompok membentuk wadah yang diharapkan dapat membantu mereka dalam memajukan usahanya, seperti mengakses permodalan dari lembaga keuangan, mengupayakan pengadaan bahan baku, dan meningkatkan pemasaran.

Untuk melakukan keempat strategi tersebut, dilaksanakan kajian-kajian dalam bentuk seminar dan lokakarya yang melibatkan seluruh pihak terkait baik dari unsur-unsur pemerintah daerah, lembaga swadaya masyarakat, pelaku usaha, pengambil kebijakan seperti anggota DPRD, perguruan tinggi lokal, asosiasi-asosiasi yang terkait dengan industri mebel seperti Asmindo, Kadin, dan sebagainya. Melalui berbagai lokakarya tersebut, didapat rekomendasi-rekomendasi kegiatan untuk dilaksanakan pada tahun berikutnya. Saya melihat kegiatan-kegiatan yang dilakukan dalam proyek 
FVC ini telah membawa banyak kemajuan, terutama bagi pelaku industri kecil mebel (perajin).

\subsubsection{Manfaat Proyek FVC bagi industri mebel}

Banyak sekali manfaat yang saya dapat dari keterlibatan saya selaku birokrat daerah dalam proyek FVC yang dilaksanakan oleh CIFOR. Manfaat yang terutama saya dapatkan adalah bertambahnya pengalaman saya bekerja bersama para peneliti yang tentu mempunyai wawasan dan khasanah ilmu yang luas dalam bidangnya, sementara saya sebagai birokrat yang bekerja di daerah memang menurut pendapat saya perlu untuk mempertajam pisau analisis yang selama ini kurang saya asah karena terjebak pada rutinitas pekerjaan yang saya jalani sehari-hari.

Manfaat lainnya yaitu saya bisa bekerja sama dengan banyak orang, baik dari kalangan pelaku usaha mebel, perguruan tinggi lokal, kalangan legislatif maupun para pemangku kepentingan lain yang terlibat dalam proyek FVC ini.

Dengan mengenal banyak orang dan bekerja bersama dengan banyak orang dari latar belakang keilmuan dan keahlian yang beragam, sudah barang tentu ini membuat saya menjadi bertambah wawasan dan kemampuan dalam melaksanakan tugas terutama dalam bidang industri mebel yang memang menjadi primadona bagi pertumbuhan ekonomi di Kabupaten Jepara.

Salah satu manfaat nyata yang saya rasakan adalah masalah pengumpulan data untuk kepentingan analisis dan pengambilan kebijakan. Selama ini, saya menggunakan data resmi yang diterbitkan oleh dinas yang menangani perindustrian dan perdagangan dalam melakukan analisis untuk bahan pengambilan kebijakan peningkatan industri mebel dan yang lainnya. Namun dengan metode yang berbeda, ternyata terdapat perbedaan yang cukup signifikan antara data dari lembaga resmi dengan data yang ada di dalam proyek FVC ini. Setelah saya renungkan dan saya analisis, ternyata memang ada perbedaan yang mendasar dalam pendataan jumlah pelaku industri mebel yang tercatat dari pendataan dalam proyek FVC ini dengan 
data yang dikumpulkan oleh lembaga resmi yang menangani perindustrian dan perdagangan.

Data tentang jumlah pelaku industri yang ada di lembaga resmi yang mengurusi perindustrian dan perdagangan di Kabupaten Jepara dikumpulkan dari pelaku usaha yang memang mempunyai izin usaha, sementara data yang dicatat di proyek FVC, semua unit usaha baik yang mempunyai izin maupun tidak. Kemudian di FVC, pelaku industri mebel berbahan baku kayu juga dicatat dengan menggunakan alat GPS (Global Positioning System). Mereka bergerak ke seluruh penjuru Kabupaten Jepara dan setiap kali menemui tumpukan kayu, baik itu di halaman rumah penduduk, gudang, maupun toko ditandai dan dicatat sebagai pelaku usaha industri mebel berbahan baku kayu.

Meskipun ada perbedaan data yang cukup signifikan, karena baik metode pengumpulan maupun pencatatannya berbeda, menurut saya tidak jadi masalah. Bagi saya, data yang dikumpulkan oleh CIFOR melalui proyek FVCnya merupakan sumber yang berharga untuk melengkapi lembaga resmi yang bertugas membina industri mebel, baik Bappeda maupun Dinas Peridustrian dan Perdagangan. Karena dengan semakin banyaknya sumber data, menurut saya, kita akan mempunyai banyak sumber dan tentunya perlu dilakukan pengecekan lapangan mana data yang akurat.

Data dari CIFOR yang dikumpulkan lewat proyek FVC memang dipilahpilah atau dibagi menurut beberapa kategori, yaitu tempat penimbunan kayu, ruang pajang, gudang, tempat kerja, dan tempat penjualan bahan pendukung industri mebel yang kesemuanya dijumlah menjadi industri yang terlibat dalam produksi mebel berbahan baku kayu di Kabupaten Jepara. Data ini menurut saya cukup lengkap dan cukup akurat, serta dapat menjadi sumber pengayaan terutama bagi saya yang pada waktu itu bekerja sebagai perencana di Bidang Ekonomi Bappeda Kabupaten Jepara.

Manfaat lain yang dapat saya peroleh dalam melaksanakan proyek FVC ini adalah, sepanjang yang saya ketahui, CIFOR melakukan analisis yang mendalam untuk mencari formula dalam memecahkan permasalahan seputar 
pengembangan industri mebel berbahan baku kayu di Kabupaten Jepara. Analisis yang mendalam ini juga merupakan pengayaan yang cukup bagus bagi saya untuk diterapkan pada komoditas potensial lainnya di Kabupaten Jepara, mengingat tugas saya di Bappeda di bidang ekonomi tidak hanya terfokus pada pengembangan bidang industri mebel berbahan baku kayu saja tapi juga industri lainnya yang potensial untuk menciptakan pertumbuhan ekonomi di Kabupaten Jepara.

Seingat saya pada awal tahun 2010, saya pernah didatangi di kantor saya oleh salah seorang peneliti CIFOR untuk menggali informasi dari saya tentang keterlibatan Bappeda dalam pengembangan industri mebel terutama yang berbahan baku kayu. Belakangan saya ketahui bahwa proyek FVC ini mencoba memetakan aktor-aktor yang diperkirakan terlibat dalam peningkatan industri mebel berbahan baku kayu baik dari instansi pemerintah, LSM, legislatif, asosiasi profesi, dan lain sebagainya.

Setelah mereka mempunyai gambaran tentang organisasi yang berperan dalam peningkatan industri mebel berbahan baku kayu di Kabupaten Jepara, mereka menyelenggarakan lokakarya dan seminar dengan melibatkan aktoraktor tersebut untuk merumuskan kegiatan apa yang diperlukan dalam proyek FVC ini. Saya melihat semua kegiatan yang dilakukan dalam proyek FVC didahului oleh pembahasan yang mendalam dalam lokakarya para aktor yang terlibat dalam pengembangan industri mebel berbahan baku kayu. Dengan demikian aktivitas yang dilakukan memang benar-benar aktivitas yang diperlukan di lapangan yang digali dari beberapa sumber yang cukup kompeten dalam bidang pengembangan industri mebel di Kabupaten Jepara baik dari kalangan birokrat, LSM, legislatif, asosiasi profesi, perguruan tinggi, pelaku usaha, dan lain-lain.

Pola penggalian permasalahan seperti yang dilakukan dalam proyek FVC dari CIFOR ini menurut saya cukup efektif dan dapat diterapkan di instansi manapun untuk mencari cara pemecahan masalah, baik dalam bidang ekonomi maupun bidang-bidang lainnya. Pengalaman pemecahan masalah dengan didahului dengan mencari aktor-aktor yang terkait dalam masalah tersebut belakangan saya coba gunakan untuk menganalisis pengembangan 
komoditas lain bersama-sama dengan lembaga yang peduli dengan pembangunan ekonomi di Kabupaten Jepara.

Harus diakui bahwa memecahkan permasalahan yang dihadapi dalam pengembangan industri kerajinan mebel berbahan baku kayu di Kabupaten Jepara memang tidak mudah. Masalah yang dijumpai saat ini memang cukup kompleks dan perlu tindakan yang serius dari seluruh pemangku kepentingan dalam industri ini. Karena itu masing-masing pihak perlu terus memainkan peranannya secara maksimal sesuai kapasitasnya masing-masing.

Ada lima permasalahan pokok yang dihadapi industri kerajinan mebel ukir di Kabupaten Jepara yang terkait dengan bahan baku, produksi, desain, pemasaran dan modal. Masing-masing masalah ini saya jelaskan di bawah ini.

\section{Permasalahan bahan baku}

Industri mebel berbahan baku kayu telah menjadi tulang punggung perekonomian Kabupaten Jepara sejak ratusan tahun lalu, terutama mebel bermotif ukiran. Sejak dahulu, kayu jati dalam mebel yang bermotif ukiran merupakan bahan baku utama. Hingga sekarang kondisi ini masih dominan namun dengan semakin berkurangnya bahan baku kayu jati, banyak produsen yang melirik penggunaan bahan baku lain seperti mahoni, utamanya untuk produk mebel yang tidak bermotif ukiran.

Sebelum krisis moneter yaitu sekitar tahun 1997 sampai dengan 2000, kebutuhan kayu jati untuk mebel berbahan baku kayu di Jepara dicukupi dari kayu yang dihasilkan oleh Perhutani. Kala itu produk utama yang dihasilkan oleh industri mebel berbahan baku kayu di Kabupaten Jepara adalah mebel bermotif ukiran dan produk yang tidak berornamen ukir (polosan) masih belum marak. Produksi mebel bermotif ukiran memerlukan keterampilan khusus dari seniman-seniman ukir dan masa pengerjaannya relatif memakan waktu yang agak lama. Dengan pasokan kayu jati dari Perhutani yang cukup pada saat itu, harga bahan baku cukup stabil dan masih dalam jangkauan para produsen dengan keuntungan penjualan yang memadai. 
Namun ketika krisis moneter di Indonesia tahun 1997/1998, nilai tukar rupiah terdepresiasi terhadap dolar dan ini menyebabkan produsen mebel yang menjual produknya keluar negeri (ekspor) mendapatkan keuntungan yang berlipat ganda. Sebaliknya bagi pembeli dari luar (importir negara asing), keadaan ini juga memacu untuk melakukan pembelian dengan kuantitas yang lebih banyak lagi karena dengan nominal dolar yang sama dengan tahun sebelumnya, mereka mendapatkan kursi yang lebih banyak.

\section{Dampak keadaan tersebut adalah semakin banyak pembeli dari luar} negeri yang melakukan transaksi pembelian mebel berbahan baku kayu di Kabupaten Jepara. Produk yang diminati oleh pembeli dari luar tersebut adalah kursi taman yang dapat diproduksi secara cepat dan massal oleh para produsen mebel di Kabupaten Jepara. Kursi taman ini tidak ada sentuhan ukirannya sama sekali dan untuk memproduksinya para produsen mebel tetap menggunakan bahan baku kayu jati yang berkualitas bagus.

Berbeda dengan mebel bermotif ukiran yang harus dikerjakan oleh senimanseniman ukir yang memerlukan waktu lama, kursi taman dapat diproduksi dengan cepat dan massal secara manual maupun menggunakan mesin. Karena itu, pemanfaatan kayu jati untuk memproduksi mebel yang tak bermotif ukir secara besar-besaran ini mengakibatkan bahan baku kayu jati menjadi berkurang karena lambatnya kecepatan untuk pemulihan dibandingkan dengan permintaan kayu jati dari para produsen. Dalam berbagai seminar dan dialog dengan para pemangku kepentingan yang terlibat dalam pengembangan industri kerajinan mebel ukir di Jepara, saat ini kayu jati yang dipasok oleh Perhutani hanya dapat memenuhi kurang dari $20 \%$ total kebutuhan para produsen mebel di Jepara.

Menurut data hasil penelitian CIFOR, pada tahun 2010 di Kabupaten Jepara terdapat 1.337 brak (Tempat kerja pembuatan mebel).. setiap unit brak mengonsumsi $104,15 \mathrm{~m}^{3}$ per tahun, konsumsi bahan baku kayu untuk brak skala kecil dan mikro sekitar 99,27 $\mathrm{m}^{3}$ per tahun, sedangkan untuk brak skala menengah dan besar masing-masing $282 \mathrm{~m}^{3}$ dan $1.115 \mathrm{~m}^{3}$ per tahun. Total prakiraan kayu yang diserap oleh industri mebel dan kerajinan kayu Jepara adalah sebesar $863.147 \mathrm{~m}^{3}$ per tahun. Angka ini jauh lebih besar dari 
produksi kayu yang dihasilkan dari hutan tanaman industri yang dihasilkan oleh Perhutani dan kekurangannya dipenuhi dari hutan rakyat dan kayu yang didatangkan dari luar Jepara.

Permasalahan bahan baku dalam industri mebel Jepara juga diperparah oleh penebangan liar yang dilakukan oleh masyarakat pada waktu terjadi kekacauan di masa reformasi. Akibatnya adalah penggundulan hutan, pasokan bahan baku menjadi berkurang drastis akhirnya memicu kenaikan harga bahan baku, terutama kayu jati.

Meningkatnya bahan baku kayu jati tentunya memukul para produsen mebel, utamanya produsen skala kecil. Keadaan ini membuat biaya produksi meningkat, sementara para produsen skala kecil (perajin) tidak secara otomatis mampu menaikkan harga jualnya karena posisi tawar mereka rendah (ketidakmampuan menembus akses pasar). Apabila hal ini berlangsung terus-menerus, maka akan membahayakan kelangsungan industri mebel berbahan baku kayu di Kabupaten Jepara. Menurut penulis, ke depannya perlu dilakukan upaya-upaya untuk mencukupi kebutuhan bahan baku kayu dari wilayah kabupaten ini sendiri, atau paling tidak, meningkatkan produksi kayu utamanya dari hutan rakyat. Oleh karena itu, aktivitas yang telah dilakukan oleh proyek FVC berupa bantuan Jati Unggul Nusantara kepada para perajin mebel untuk ditanam di lahannya, mudah-mudahan akan dapat meningkatkan upaya para produsen mebel agar semaksimal mungkin ikut serta menanam bahan baku. Diharapkan mereka tidak hanya menjadi konsumen kayu saja tetapi paling sedikit, dapat memberikan sumbangan terhadap ketersediaan bahan baku kayu di sini.

Mahalnya harga bahan baku yang harus dibayar oleh produsen adalah karena: Pertama, memang ada kenaikan harga kayu jati dari Perhutani. Ke dua, para produsen mebel terutama perajin tidak bisa langsung mengakses kayu dari Perhutani karena ada pembatasan harus dalam jumlah tertentu, sedangkan para perajin skala kecil membeli kayu dalam jumlah yang kurang dari yang dipersyaratkan. Akibatnya para perajin membeli kayu bukan dengan harga dasar yang ditetapkan oleh Perhutani yang memang sudah tinggi, tetapi juga harus ditambah dengan keuntungan yang dimasukkan dalam harga kayu 
oleh pedagang kayu, ditambah biaya angkut dan biaya-biaya lainnya. Untuk itu ke depannya, selain kegiatan penanaman Jati Unggul Nusantara bantuan CIFOR oleh perajin, perlu dipertimbangkan untuk melakukan diversifikasi bahan baku kayu selain jati.

Di samping diversifikasi bahan baku, barangkali perlu juga diciptakan desain-desain mebel yang hemat bahan baku. Sebetulnya di Kabupaten Jepara ada suatu lembaga yang bidang garapnya adalah pengembangan desain-desain mebel yaitu JFDC, kantornya berada di gedung JTTC (Jepara Trade and Tourism Centre) dan satu lokasi dengan kantor APKJ. Para perajin perlu mencoba untuk bekerja sama dengan JFDC untuk menciptakan inovasi desain mebel yang laku di pasaran, namun hemat bahan baku. Bila hal ini bisa dimanfaatkan, biaya produksi akan bisa dihemat, meskipun harus diakui hal ini tidaklah mudah. Hal lain yang bisa dilakukan para produsen skala kecil adalah membentuk kelompok, berupa koperasi atau bentuk yang lainnya untuk mengakses bahan baku dari Perhutani. Dengan berkelompok, mereka dapat mengikuti lelang kayu dari Perhutani untuk didistribusikan kepada anggotanya. Bila hal ini bisa dilakukan, maka biaya perolehan bahan baku akan bisa ditekan dan ini berarti pengurangan biaya produksi yang akhirnya akan bermuara pada peningkatan pendapatan bagi para produsen mebel skala kecil.

Sepengetahuan saya, pembentukan kelembagaan untuk memperkuat para perajin juga sudah dilakukan dalam proyek FVC ini. Melalui proyek ini CIFOR telah memfasilitasi para perajin untuk membentuk kelembagaan dan pada tahun 2009 telah terbentuk APKJ. Menurut penulis, APKJ dapat menjadi media bagi para pelaku industri mebel skala kecil (perajin) untuk mengatasi permasalahan-permasalahan dalam menjalankan usahanya, terutama permasalahan bahan baku, pemasaran, dan peningkatan kualitas produk.

Saya pernah berkunjung ke Belanda yang perekonomiannya sudah maju dan melihat bagaimana asaha kecil dan menengah di sana bisa berhasil mengatasi permasalahannya dan menekan kendala-kendala yang dijumpai 
dalam menjalankan usahanya. Usaha kecil dan menengah (UKM) yang saya kunjungi itu adalah usaha pertanian, tepatnya hortikultura (sayuran dan buah-buahan) serta petani bunga.

Meskipun tidak tepat sama, bagaimana para petani mengelola usahanya dan membentuk lembaga (berkelompok) untuk memajukan usahanya serta menghadapi pasar secara bersama-sama, saya pikir dapat diterapkan untuk komoditas apapun termasuk komoditas mebel di Jepara. Saya melihat bagaimana para petani bunga di sana membentuk lembaga pemasaran dalam bentuk koperasi dan berhasil menjadi lembaga pemasaran yang tangguh, yang setiap harinya melakukan penjualan bunga dengan cara lelang dengan pembeli dari seluruh Eropa bahkan dunia. Koperasi seperti ini menjadi alat pemasaran yang efektif bagi para petani bunga di sana untuk mengakses pasar dan berdasarkan wawancara dengan mereka, hampir tidak dijumpai kendala yang berarti dalam memasarkan produknya. Melalui koperasi dan lembaga lelang tersebut mereka dapat menjual produknya dengan harga yang sangat baik.

Ada juga beberapa petani tomat yang membentuk lembaga koperasi yang bergerak di bidang pengemasan modern. Koperasi tersebut mendirikan pabrik yang mengemas produksi tomat dari anggotanya dengan peralatan canggih dan memasarkan tomat kemasan tersebut baik ke supermarket yang ada di Belanda dan diekspor ke negara Eropa lainnya. Dengan membentuk koperasi, para petani tomat mendapat keuntungan tidak hanya dari produk tomatnya, tetapi juga dari hasil usaha pabrik kemasan tersebut. Sekali lagi terlihat bahwa kata kunci dalam keberhasilan mereka adalah mengatasi persaingan dan berkelompok.

Berdasarkan uraian saya di atas, kegiatan CIFOR melalui proyek FVC saya kira sudah tepat dengan memfasilitasi para perajin kecil untuk berkelompok dengan membentuk asosiasi. Sekarang tinggal para pengurus APKJ yang perlu bekerja keras membangun jaringan dengan asosiasi sejenis lainnya atau seluruh pihak terkait lainnya dengan pengembangan industri mebel di Kabupaten Jepara bahkan mungkin di luar Jepara. 


\section{Permasalahan produksi}

Permasalahan ini terutama berkaitan dengan kualitas dan desain produk. Kualitas produk yang rendah dan desain yang kurang laku di pasaran tentunya akan memengaruhi hasil penjualan yang akhirnya akan memengaruhi pendapatan produsen mebel berbahan baku kayu. Hal ini terjadi pada awal era reformasi, ketika krisis politik waktu itu diikuti dengan krisis ekonomi, dan nilai rupiah terdepresiasi terhadap dolar. Keadaan ini membawa dampak bagi banyak pelaku usaha baru di bidang mebel di Jepara karena tertarik oleh keuntungan yang tinggi.

Sayangnya, para pelaku usaha yang relatif baru ini kebanyakan kurang memperhatikan kaidah-kaidah kualitas dalam memproduksi mebel, misalnya mereka tidak melakukan proses pengeringan kayu sesuai dengan yang seharusnya, penerapan teknologi konstruksi yang kurang benar, dan alasan lainnya. Karena kualitas yang kurang baik pada waktu itu, maka citra mebel dari Jepara di dunia menjadi menurun. Hal seperti tentunya tidak boleh dibiarkan berlangsung terus.

Selain proses pengeringan dan teknologi yang benar, penggunaan kayu yang sudah benar-benar tua harus diterapkan jika para perajin ingin menghasilkan produk yang berkualitas. Bahkan ketika para perajin menggunakan kayu kering dan menerapkan teknologi konstruksi yang benar, bila umur kayu yang digunakan belum mencapai standar (kayu yang digunakan masih terlalu muda), kualitas produk mebel yang dihasilkan akan terpengaruh. Mebel dengan kayu muda ini kekuatannya akan kalah jauh dibandingkan dengan mebel yang diproduksi dari kayu yang cukup umur. Dengan demikian, untuk memproduksi mebel yang berkualitas, selain teknologi konstruksi yang benar dan pengeringan yang benar, juga harus digunakan kayu yang benarbenar cukup umur.

Kadang-kadang untuk menutupi berbagai kekurangan tersebut di atas, para perajin melakukan tindakan-tindakan tertentu misalnya, menggunakan teknik tertentu seperti pemolesan, sehingga produk yang dibuat sepertinya berkualitas tinggi dan ditawarkan dengan harga yang sesuai dengan kualitasnya. Namun sebenarnya barang tersebut berkualitas rendah. 
Para perajin tidak sadar bahwa sebenarnya tindakan tersebut dalam jangka panjang akan merugikan mereka. Tindakan pragmatis ini dilakukan untuk meningkatkan penjualan dengan biaya produksi rendah, karena bagi mereka yang penting produknya laku dan mereka mendapatkan keuntungan tinggi. Dalam jangka pendek barangkali hal tersebut bisa berhasil, tetapi dalam jangka panjang akan menyebabkan kekecewaan konsumen. Tentunya konsumen yang kecewa akan pindah ke produsen lain. Bahkan kalau citra tersebut sudah menyangkut daerah, bukan tidak mungkin para konsumen akan mencari mebel ke daerah lain. Hal seperti ini tentunya tidak boleh terjadi, dan para pelaku industri kerajinan harus memperbaiki perilakunya. Mereka harus benar-benar menerapkan tata cara memproduksi barang yang benar, mulai dari penggunaan bahan baku yang benar, teknologi yang benar, dan persyaratan kayu yang tepat.

Saya berharap dan tampaknya pembinaan untuk memproduksi mebel dengan cara-cara yang benar sudah dilakukan oleh CIFOR dalam proyek FVC ini. Di samping itu, pemerintah daerah melalui SKPD (Satuan Kerja Perangkat Daerah) terkait juga sudah melakukan pembinaan. Banyak sekali pelatihan, seminar, dan lokakarya tentang tata cara memproduksi mebel dengan benar telah dilaksanakan. Sekarang tampaknya citra mebel Jepara di mata dunia sedang merangkak naik.

\section{Permasalahan desain}

Pada umumnya, para perajin memproduksi mebelnya sesuai pesanan baik desain, bahan baku yang digunakan, sampai dengan finishing-nya. Ketergantungan ini menyebabkan mereka tidak bisa berinovasi untuk menciptakan desain-desain baru yang memang disukai pasar. Tingginya ketergantungan mereka kepada pembeli ini membuat daya tawar mereka menjadi lemah. Dengan demikian, mereka tidak bisa menciptakan harga karena harga lebih banyak ditentukan oleh importir di luar negeri sehingga keuntungan para perajin menjadi tidak maksimal.

Ke depannya, perlu diupayakan agar para perajin mampu mengakses informasi pasar dan peka terhadap desain-desain yang sedang digemari oleh pasar. Dengan kemampuan yang meningkat ini, para perajin diharapkan 
dapat menciptakan desain-desain sendiri yang memang disukai pasar dan mampu memasarkan produknya dengan harga oleh mereka tetapkan sendiri, bukan harga yang diciptakan oleh pembeli. Dengan adanya JFDC dan APKJ, barangkali perlu dicoba kerja sama antara keduanya untuk pengembangan desain mebel dari para perajin.

\section{Permasalahan modal}

Berdasarkan informasi dari beberapa perajin yang saya temui dalam beberapa kesempatan, mereka mendapatkan permodalan lebih kurang $40 \%$ dari perbankan, 20\% dari pemberi order dan sisanya dari sumber-sumber lain. Keadaan ini sebenarnya cukup baik mengingat secara nasional kredit dari perbankan yang diakses oleh para pelaku usaha kecil dan menengah kurang dari 10\%. Dengan demikian, bila dibandingkan dengan keadaan nasional secara makro, akses kredit perbankan bagi UMKM di Kabupaten Jepara cukup besar.

Untuk mengetahui secara lebih mendalam tentang dinamika aksesibilitas industri mebel ke kredit perbankan di Kabupaten Jepara sebenarnya bisa dilihat dari hubungan antara para pelaku industri mebel dengan perbankan secara umum. Berapa kredit yang tersalur dari perbankan di Jepara kepada para pelaku industri ini, bagaimana pembayarannya lancar atau tidak, dan berapa NPL (Non-Performing Loan) dari bank yang disebabkan oleh macetnya pelunasan kredit dari para pelaku industri mebel.

Dengan menjawab pertanyaan-pertanyaan tersebut, akan diketahui sebenarnya kondisi industri mebel di Kabupaten Jepara saat ini. Apakah industri ini berkembang dengan baik dan prospektif bagi dunia perbankan atau bahkan sedang menurun sehingga perbankan menjadi berhati-hati dalam menyalurkan kreditnya kepada pengusaha industri ini.

Melihat banyaknya permasalahan yang dihadapi saat ini, banyak berkembang pendapat di dunia perbankan di Jepara bahwa industri ini kondisinya sedang menurun, sehingga mereka sangat berhati-hati dalam mendistribusikan kreditnya kepada pengusaha mebel di Kabupaten Jepara. Namun melihat daya tahan industri mebel Jepara yang sudah sekian lama masih tetap eksis 
meskipun mengalami proses naik turun, maka sebenarnya saat ini hanya sedang terhambat perkembangannya. Industri ini tetap mempunyai prospek positif untuk dapat mencapai kembali bahkan melebihi zaman ketika terjadi booming pada tahun 1998 sampai dengan 2000.

Untuk mengatasi masalah permodalan, diperlukan upaya-upaya pemerintah untuk membina para pelaku industri ini dalam mengupayakan modal bukan hanya dari sektor perbankan. Barangkali perlu diupayakan dari sektor-sektor lain seperti lembaga keuangan mikro, koperasi, dan sebagainya. Peningkatan akses ke permodalan ini sangat penting diupayakan demi pengembangan suatu usaha, terutama untuk meningkatkan skala usaha.

\section{Permasalahan pemasaran}

Para perajin memasarkan mebelnya melalui kerja sama dengan eksportir atau memasarkannya kepada pembeli dalam negeri yang datang kepada mereka. Dengan kondisi semacam ini tentunya dari sisi pemasaran mereka berada dalam posisi yang lemah. Di samping itu, berkembang juga persaingan yang kurang sehat di antara para perajin, kadangkala mereka saling membanting harga hanya sekedar supaya barangnya laku terjual.

Keadaan yang demikian akhirnya akan merusak harga barang dan membuat nilai barang mereka menjadi murah dan keuntungan yang didapatkan menjadi tidak memadai dan bahkan ada yang sampai merugi sehingga pelan-pelan usahanya bangkrut. Oleh karena itu, dapat dimengerti bila pada saat sekarang terjadi penurunan jumlah pelaku usaha dibanding pada saat booming tahun sekitar tahun 1998 sampai 2000. Keadaan demikian tentunya tidak boleh dibiarkan terus-menerus dan mungkin diperlukan standarisasi harga untuk produk yang sama dengan kualitas yang sama.

Selain itu dengan adanya asosiasi perajin mungkin bisa diwujudkan komitmen bersama untuk tidak melakukan banting harga. Namun mewujudkan standarisasi harga tidaklah mudah mengingat mebel yang dibuat untuk jenis yang sama, kualitasnya bisa berbeda sesuai kualitas bahan baku dan keterampilan pembuatnya. Namun saya kira untuk barang yang jenis dan kualitasnya sama, bisa diciptakan standarisasi harga asalkan ada 


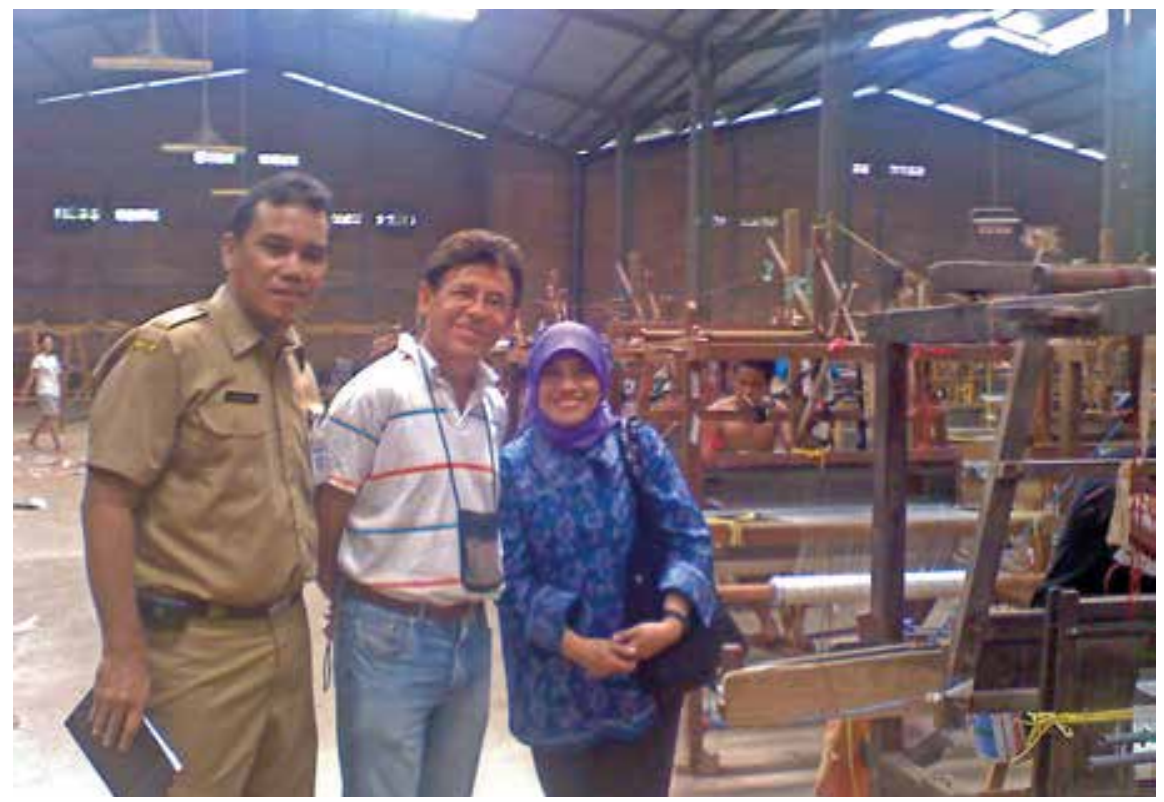

Gambar 6.3. Mengantar Dr. Ogenis Brillhante, Staf Pengajar IHS Erasmus University Rotterdam Belanda ke Desa Troso

kemauan yang sungguh-sungguh dari para perajin dan sarana untuk itu sudah ada, yaitu dengan terbentuknya asosiasi pengrajin kecil Jepara.

Permasalahan lain di bidang pemasaran mebel Jepara saat ini adalah masih sedikitnya jumlah para perajin yang mencoba melakukan penetrasi pasar, misalnya melalui keikutsertaan dalam pameran-pameran atau melakukan promosi sendiri. Keadaan ini mungkin karena sejak dahulu mereka mengandalkan keterkenalan daerah Jepara sebagai kota ukir yang banyak memproduksi mebel ukir sehingga pembeli baik dari luar negeri maupun domestik yang datang sendiri mencari mebel di Kabupaten Jepara. Para perajin kebanyakan dalam posisi pasif dalam memasarkan mebelnya, dan hanya menjual mebelnya kepada para pembeli melalui pedagang perantara atau para pembeli langsung yang datang ke Jepara. 
Dalam kondisi semacam ini, tentunya para perajin dikendalikan oleh para pembeli dalam penciptaan harga karena mereka tidak tahu harga pasar produk yang mereka jual ke pedagang perantara di luar negeri. Dengan demikian, margin keuntungan yang diterima para perajin rendah dan keuntungan tertinggi dinikmati para importir di luar negeri.

Ke depannya, dengan keberadaan proyek FVC di Kabupaten Jepara, saya kira perlu diupayakan pemberdayaan perajin di bidang pemasaran. Saya mendengar dari beberapa perajin mebel bahwa sebenarnya hal ini sudah dilakukan, di antaranya memperkenalkan para perajin dengan teknologi informasi yang dapat memfasilitasi mereka untuk membuat web di internet yang berisi tentang produk-produk mereka. Di samping itu, CIFOR juga tampaknya telah berusaha memfasilitasi mereka untuk mengikuti pameran-pameran.

Saluran perdagangan mebel yang banyak terjadi sampai sekarang adalah perajin memasarkan mebelnya melalui pedagang perantara yang kemudian menjualnya di luar daerah dan selanjutnya dibeli oleh konsumen. Cara lainnya adalah perajin menjual kepada eksportir dan kemudian diekspor. Dengan cara-cara ini, para perajin tidak langsung berhubungan dengan pasar mebel di negara tujuan ekspor. Karena tidak tahu harga pasar, para perajin hanya pasrah menerima harga yang ditawarkan oleh pedagang perantara dan nilainya kurang menguntungkan bagi perajin. Pedagang perantara bisa menekan harga karena mereka dapat berpindah-pindah dari satu perajin ke perajin yang lain.

Salah satu upaya yang perlu dilakukan oleh seluruh pihak yang terkait dengan pengembangan industri ini adalah bagaimana meningkatkan daya tawar para perajin. Semoga saja keberadaan proyek FVC di Jepara dapat meningkatkan kemampuan para pelaku industri mebel dalam memasarkan produknya. Karena industri kerajinan mebel di Jepara sudah berlangsung turun temurun dan sudah menjadi aset daerah, akan sangat disayangkan bila pelaku-pelaku industri ini semakin berkurang karena selalu merugi dalam menjalankan usahanya. 


\subsubsection{Manfaat nyata FVC bagi Penulis}

Sepanjang penulis ketahui, proyek FVC yang dimulai sekitar tahun 2008 ini merupakan kerja sama antara CIFOR, pemerintah Kabupaten Jepara dan ACIAR. MoU dari proyek ini ditandatangani di kantor CIFOR di Bogor antara Bupati Jepara, perwakilan dari CIFOR dan ACIAR. Penulis sendiri terlibat dalam proyek ini sebagai wakil dari pemerintah daerah dari unsur Bappeda karena bidang tugas penulis saat itu sebagai Kepala Bidang Ekonomi yang salah satu tugasnya adalah menyusun perencanaan pembangunan ekonomi, industri mebel.

Tujuan dari kerja sama dalam proyek FVC ini adalah untuk melakukan penelitian rantai nilai industri mebel jati dan mahoni di Jepara dan hasil yang diharapkan adalah peningkatan efisiensi industri ini dan peningkatan taraf penghidupan perajin mebel Jepara. Sampai saat saya menulis artikel ini, seingat saya ada beberapa hasil yang telah dicapai oleh proyek ini. Beberapa produk yang dihasilkan dari kegiatan FVC antara lain: Peta wisata dan belanja mebel Jepara yang berisi informasi tentang sentra-sentra kerajinan mebel di Kabupaten Jepara sampai ke tingkat desa dan produk mebel yang dihasilkan. Di Kabupaten Jepara ini masing-masing desa memang mempunyai spesifikasi khusus dalam memproduksi mebel dari kayu. Misalnya untuk lemari banyak diproduksi di Desa Sukodono.

Adanya peta wisata ini, menurut saya merupakan salah satu terobosan yang bagus untuk meningkatkan akses pasar para perajin. Siapapun mereka, apakah wisatawan atau pebisnis yang memang mencari produk mebel dari Jepara untuk diekspor atau dijual di pasar domestik, dapat dengan mudah mencari lokasi desa yang memproduksi barang yang dicari. Dengan demikian, secara tidak langsung ini merupakan promosi bagi para produsen di lokasi desa sentra tersebut.

Selain itu, dengan adanya peta wisata tersebut, produsen mebel juga dituntut untuk meningkatkan kualitas produknya. Ini menjadi semacam antisipasi jika seandainya banyak pembeli datang ke sebuah desa sentra dan bila kualitas produk yang dihasilkan baik, maka pembeli pasti akan bercerita kepada koleganya dan akan semakin banyak pembeli yang datang untuk 
membeli produk yang dihasilkan. Akan tetapi, bila produsen di desa sentra tidak dapat meningkatkan kualitas produknya atau bahkan mereka banyak memproduksi barang yang berkualitas rendah, maka akan terjadi sebaliknya.

Proyek FVC ini juga telah memfasilitasi terbentuknya kelembagaan perajin yaitu APKJ dan mengadakan pelatihan-pelatihan untuk meningkatkan kemampuan dalam rangka peningkatan usaha para perajin. Berdasarkan informasi dari para perajin mebel, beberapa pelatihan yang telah dilaksanakan oleh CIFOR melalui proyek ini, antara lain pelatihan manajemen pameran, pemasaran, dan kewirausahaan. Aktivitas-aktivitas ini menurut pendapat saya akan membawa manfaat besar bagi para perajin mebel di Jepara dalam mengembangkan usahanya. Di samping itu, dengan berkelompok dalam suatu lembaga, para perajin mebel dapat mengupayakan untuk mengatasi permasalahan bersama dalam bidang industri mebel, seperti upaya mengadakan bahan baku dan pemasaran secara bersama.

Asosiasi perajin kecil sudah terbentuk dan hingga tulisan ini dikerjakan sudah mulai beraktivitas. Ketika masih di Bappeda dulu saya juga pernah didatangi oleh teman-teman dari APKJ untuk berdiskusi tentang pengembangan industri kerajinan mebel di Jepara. Asosiasi lain yang terkait dengan pengembangan kerajinan mebel di Jepara telah ada seperti Asmindo dan Kadin. Oleh karena itu, menurut saya pengurus APKJ perlu terus bekerja bersama-sama dan bahu-membahu dengan organisasi sejenis yang telah mempunyai pengalaman dalam bidang industri mebel. Tidak kalah pentingnya bagi APKJ untuk sering-sering berkomunikasi dengan instansi pemerintah daerah sehingga dapat mengakses program-program yang sesuai dengan visi, misi, dan tujuan pembentukan APKJ.

Beberapa kegiatan yang ditujukan untuk menembus akses pasar yang difasilitasi CIFOR di antaranya berupa keikutsertaan dalam pameranpameran perdagangan dan pengembangan portal pemasaran melalui website www.javamebel.com yang menurut saya suatu langkah maju yang belum pernah dilakukan oleh para perajin sebelumnya.

Melalui keikutsertaan dalam pameran-pameran dan promosi produk lewat internet menurut saya akan dapat terjadi pergerakan naik dalam rantai 
nilai pemasaran. Kalau sebelumnya posisi perajin hanya sebagai produsen yang memasok barang kepada eksportir, maka dengan kemampuan untuk menembus pasar lokal, regional dan international, posisi perajin bisa meningkat menjadi penjual yang langsung dapat berhubungan dengan pembeli. Meskipun mewujudkan hal ini tidak semudah membalik telapak tangan, harus diakui bahwa diperlukan kerja keras dari semua pihak yang terkait dengan industri ini sesuai peran dan fungsinya masing-masing.

Kegiatan lainnya yang telah membawa perubahan yang cukup berarti bagi para perajin dalam proyek FVC ini adalah upaya peningkatan kerja sama antara para perajin dengan petani hutan dan penjual kayu, termasuk penanaman jati di pekarangan sendiri atau di lahan komunal sebagai model peningkatan pasokan bahan baku dalam jangka panjang. Kegiatan ini diharapkan akan dapat mengatasi masalah kelangkaan bahan baku.

Seperti kita ketahui bersama, ketersediaan bahan baku utamanya kayu jati di Jepara jumlahnya kira-kira baru mencukupi 20\% dari total kebutuhan seluruh produsen mebel di sini sementara sisanya dari didatangkan dari luar wilayah sekitarnya. Seperti telah dijelaskan di atas biaya bahan baku yang ditanggung oleh perajin menjadi lebih mahal, apalagi bila terjadi kelangkaan kayu, yang dapat memukul aktivitas para perajin dan menghambat perkembangan usahanya atau bahkan membuat mereka mungkin bangkrut dan perajin menghentikan usahanya. Dengan adanya penanaman jati di pekarangan perajin sendiri dan di lahan-lahan komunal sampel, kegiatan ini diharapkan dapat berkembang ke lahan milik perajin lainnya. Dengan demikian, dalam 10 atau 20 tahun ke depan diharapkan akan mengurangi tekanan dalam ketersediaan bahan baku.

Kemudian kegiatan lainnya yang menurut saya cukup bermanfaat dan dalam mengatasi permasalahan industri mebel berbahan baku kayu adalah kegiatan mewujudkan green furniture. Pendekatan ini berusaha meningkatkan kemampuan perajin dalam memasuki pasar mebel yang bersertifikat melalui pelatihan sertifikasi lacak balak. Pelatihan ini membantu kemampuan para perajin dalam memproduksi mebel yang bersertifikat yang baru-baru ini disyaratkan oleh negara tertentu, terutama Eropa, yang membeli produk 
mebel dari negara lain. Sertifikasi ini dilakukan untuk mengantisipasi kerusakan lingkungan sebagai akibat penggunaan bahan baku kayu secara massal dalam bidang industri mebel. Dengan kemampuan perajin untuk mengurus sertifikasi, kemampuan perajin diharapkan akan meningkat dalam mengatasi hambatan perdagangan yang berlaku di negara-negara importir mebel.

Dari semua aktivitas CIFOR yang melibatkan seluruh pemangku kepentingan dalam pengembangan industri mebel, baik pemerintah, pemerintah daerah, dan swasta, banyak sekali manfaat yang saya dapat. Manfaat pertama adalah bertambahnya kolega/teman dari berbagai kalangan dari kalangan pemerintah, pelaku usaha mebel, asosiasi dan perguruan tinggi. Semua pihak ini merupakan orang-orang yang mempunyai kepedulian terhadap pengembangan industri mebel dan perekonomian di Kabupaten Jepara secara umum. Manfaat ke dua adalah saya memperoleh pembelajaran yang sangat berharga dalam upaya memecahkan masalah pengembangan komoditas melalui keterlibatan dalam kegiatan proyek FVC ini, baik berupa seminar-seminar dan diskusi lokakarya.

Peningkatan kemampuan bagi seorang aparatur pemerintah seperti saya yang bertugas menyusun perencanaan pembangunan daerah merupakan sesuatu yang amat penting. Di kegiatan FVC ini, saya banyak bekerja dan bertemu dengan orang-orang dari berbagai latar pendidikan dan profesi yang tentunya mempunyai sudut pandang dan cara yang berbeda dalam mencoba memecahkan permasalahan pembangunan, khususnya dalam pengembangan industri mebel. Bersama berbagai pihak dalam saya belajar mengidentifikasi masalah-masalah yang dihadapi dan kemudian mencoba merumuskan caracara mengatasi masalah yang dihadapi, dalam hal ini pengembangan industri mebel di Kabupaten Jepara. Meskipun saya sebenarnya sudah banyak melakukan kegiatan-kegiatan sejenis sebagai aparatur yang mempunyai tugas menyusun perencanaan pembangunan di bidang ekonomi, keterlibatan saya di proyek FVC memberi kesempatan untuk melakukan terobosan baru dalam menyusun perencanaan. Kesempatan ini sangat berharga bagi saya untuk meningkatkan kemampuan sebagai aparatur pemerintah dalam bidang perencanaan pembangunan. 
Mengukir Fajar: Perajin Mebel Berbisnis, Berserikat dan Meraih Sertifikat Legalitas Kayu

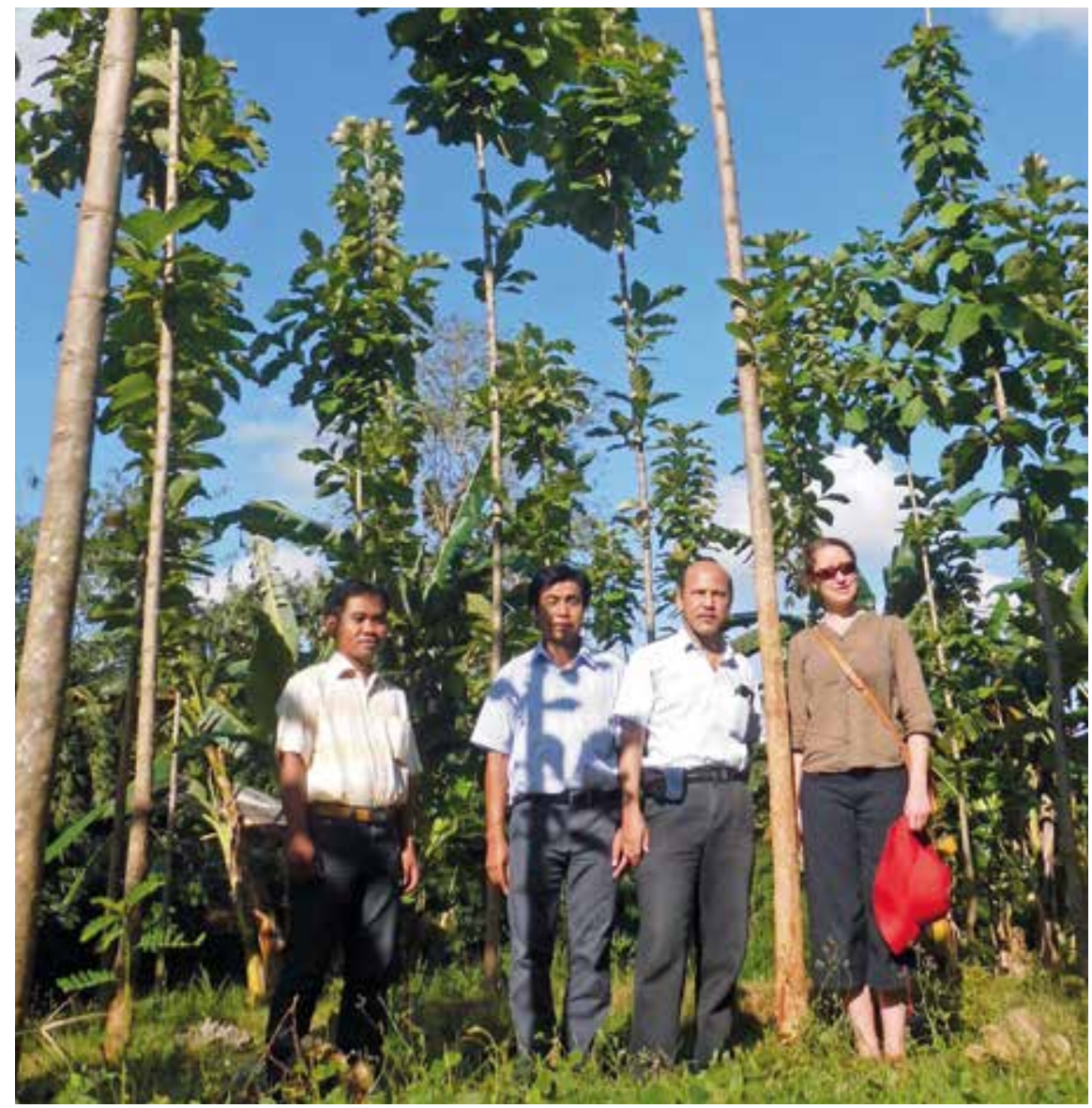

Gambar 6.4. Kunjungan tim peninjau ACIAR ke lokasi penanaman JUN yang merupakan inisiasi proyek FVC

Beberapa hal yang merupakan pengayaan bagi saya adalah bagaimana seluruh pemangku kepentingan yang terlibat dalam proyek ini merumuskan atau mencermati apa yang terjadi dengan industri mebel saat ini. Bersamasama kami memotret keadaan industri mebel saat ini, permasalahanpermasalahan yang dihadapi dari sisi bahan baku, produksi, desain dan pemasaran dan kemudian merumuskan apa yang diinginkan di masa depan 
dan merencanakan langkah-langkah untuk mencapainya. Selanjutnya, memetakan siapa yang melakukan apa, merupakan pembelajaran bagi seluruh pihak yang terlibat dalam kegiatan proyek ini.

Satu hal yang mungkin banyak membawa manfaat bagi saya adalah kesempatan bekerja bersama para peneliti dari CIFOR maupun dari lembaga lainnya yang terlibat dalam proyek ini. Terus terang sebagai birokrat, kemampuan analisis saya mungkin memang agak kurang, mungkin karena sebagai aparatur pemerintah saya sering terjebak dalam rutinitas dan bekerja dengan prosedur yang sudah baku. Dengan bekerja bersama teman-teman peneliti dari CIFOR dan lembaga lainnya, saya bisa menambah pengetahuan bagaimana yang seharusnya dilakukan dalam memecahkan suatu masalah.

Demikianlah berbagai manfaat yang dapat saya rasakan dengan keberadaan proyek FVC di Jepara. Dari tulisan saya di atas, dapat dilihat banyak juga manfaat dari keberadaan proyek ini baik bagi pelaku usaha mebel utamanya perajin kecil, bagi asosiasi yang menaruh perhatian pada pengembangan industri mebel, dan bagi aparatur pemerintah yang terlibat dalam pengembangan industri ini.

Seingat saya, berdasar MoU proyek FVC akan berakhir tahun 2013 ini. Pertanyaan yang kemudian muncul adalah bagaimana setelah proyek ini berakhir? Apakah perajin kecil yang telah membentuk kelembagaan dan menjalankan kelembagaannya dengan baik dapat terus meningkatkan kesejahteraan anggotanya? Untuk menjawab pertanyaan ini mungkin perlu pemikiran bersama, mengingat kemampuan sumber daya manusia yang terbatas di kalangan perajin, agar apa yang telah dimulai dengan keberadaan proyek FVC ini dapat dilanjutkan dan berkembang dengan lebih maju lagi di masa-masa yang akan datang.

\subsection{Harapan-harapan untuk kemajuan ke depan}

Industri kerajinan mebel ukir di Kabupaten Jepara merupakan industri yang menjadi tulang punggung perekonomian daerah. Dari angka-angka statistik dapat dilihat bahwa kontribusi terbesar untuk PDRB di Kabupaten Jepara adalah industri pengolahan sebesar lebih kurang 28\%, kemudian sektor 
pertanian sebesar lebih kurang 26\% dan ke tiga sektor perdagangan hotel dan restoran sebesar lebih kurang 24\%. Dari sembilan sektor yang menyumbang PDRB Kabupaten Jepara, ketiga sektor tersebut merupakan penyumbang yang cukup besar. Apabila sektor industri pengolahan diuraikan lagi ke dalam sektor-sektor di bawahnya, maka lebih dari 50\% sumbangan sektor industri pengolahan dihasilkan dari industri kerajinan mebel yang berbahan baku kayu.

Selain menjadi penyumbang terbesar PDRB Kabupaten Jepara, industri kerajinan mebel juga banyak menyerap tenaga kerja. Tidak kurang dari sekitar 100 ribu orang tenaga kerja, baik sebagai pegawai, pengusaha, tukang, dan buruh. Karena itu sudah sepatutnyalah apabila pemerintah daerah dan seluruh pihak yang terkait dengan industri ini bahu membahu berupaya meningkatkan kinerja industri ini.

Sebenarnya telah banyak upaya yang telah dilakukan oleh pemerintah daerah untuk meningkatkan kinerja industri ini, berupa upaya memperluas akses pasar melalui bantuan dana kepada asosiasi untuk mengikuti pameranpameran di dalam dan luar negeri, upaya untuk meningkatkan kualitas para produsen melalui kegiatan pelatihan-pelatihan teknik produksi, maupun manajemen usaha. Namun demikian, pemerintah daerah saja tidaklah cukup untuk mengembangkan industri yang strategis bagi Kabupaten Jepara ini, sehingga diperlukan keterlibatan seluruh pihak terkait di dalamnya untuk secara bersama-sama berupaya membangun dan meningkatkan kinerja industri ini.

Keberadaan proyek ini di Kabupaten Jepara, menurut saya cukup banyak memberikan sumbangan yang berarti bagi upaya pengembangan industri ini. Perkembangan nyata dari hasil keberadaan proyek ini adalah CIFOR berhasil meningkatkan kemampuan para perajin kecil dalam upayanya untuk meningkatkan usahanya. Ini terlihat dari terbentuknya asosiasi perajin kecil yang berhasil didirikan oleh para perajin. Sebelumnya, mungkin karena keterbatasan kemampuan sumber daya manusia, para perajin kecil tidak mempunyai wadah yang dapat dijadikan sebagai media untuk membicarakan permasalahan bersama. Meski sudah banyak asosiasi dengan bidang garap 
industri mebel didirikan di Kabupaten Jepara, seperti Asmindo dan yang lainnya, saya berharap teman-teman dari APKJ dapat bekerja sama bahumembahu dengan asosiasi lain dengan bidang garap yang sama untuk meningkatkan kinerja industri mebel di Jepara.

Saya berpendapat APKJ bisa mencoba untuk mengupayakan pemecahan permasalahan seputar perajin yang secara umum mempunyai karakteristik yang sama. Meskipun ada asosiasi yang mempunyai bidang garap yang sama barangkali karakteristik permasalahan anggotanya berbeda. Dalam masalah modal misalnya, perajin kecil barangkali modalnya masih kisaran ratusan juta, sehingga permasalahan yang muncul berbeda dengan pengusaha besar yang modalnya bisa puluhan miliar. Kemudian, permasalahan lainnya di bidang pemasaran bagi pengusaha besar mungkin lebih terkait dengan bagaimana menembus pasar ekspor, sementara para perajin kecil mungkin baru sebatas membicarakan pasar lokal dan domestik.

Dengan kondisi tersebut di atas, maka APKJ dan assosiasi mebel lainnya yang sudah lebih dulu berkiprah di Jepara bisa bekerja sama membentuk sinergi yang kokoh untuk kemajuan bersama. Sementara para perajin bisa menimba pengalaman dari teman-teman Asmindo misalnya, bagaimana menjalankan roda organisasi, melakukan pengembangan industri mebel dan bekerja sama dengan pihak-pihak lain.

Saya mencoba untuk melakukan kategorisasi pelaku-pelaku industri mebel berbahan baku kayu di Jepara. Hasil dari pemantauan saya terhadap jenis pelaku industri ini dapat saya simpulkan sebagai berikut: penjual bahan baku (kayu), perajin kecil, perusahaan yang memasarkan mebel untuk pasar domestik dan ekspor, dan importir yang ada di luar negeri. Dari antara para pelaku ini, para perajin posisinya masih lemah karena tidak mampu menembus pasar. Sementara itu margin keuntungan terbesar dinikmati oleh importir yang ada di luar negeri. Karena itu diperlukan kerja sama semua pihak untuk dapat menciptakan rantai tata niaga yang setara, di mana setiap pelaku dalam rantai tata niaga industri ini menerima keuntungan yang adil sesuai dengan perannya masing-masing. 
Upaya-upaya yang telah dan sedang dilakukan oleh CIFOR bersama seluruh pemangku kepentingan dalam proyek FVC diharapkan dapat meningkatkan posisi semua pihak sesuai dengan perannya dalam rantai tata niaga. Salah satu kelemahan dari pelaku industri kecil di Indonesia dan mungkin juga para pelaku industri kerajinan mebel di Jepara adalah ingin meraih keuntungan secara cepat dengan biaya yang ditekan seminimal mungkin. Untuk merealisasikan hal ini, tidak jarang mereka menggunakan bahan baku yang kurang berkualitas sehingga produk yang dihasilkan berkualitas rendah.

Hal ini terjadi mungkin karena perajin belum mengetahui tata cara pengeringan kayu yang benar atau memang ada unsur kesengajaan untuk menekan biaya produksi. Namun dengan adanya kegiatan FVC ini, saya berharap ada penyuluhan mengenai proses produksi yang benar, mulai dari pemilihan bahan baku sampai perlakuan bahan baku sebelum dibuat mebel, sehingga pelaku industri yang memahami tata cara proses produksi yang benar akan semakin bertambah dan akhirnya upaya untuk meningkatkan kualitas produk mebel dari Jepara dapat terwujud.

Peningkatan kualitas mebel Jepara akan dapat mengembalikan kepercayaan pembeli dari dalam maupun luar negeri. Kondisi ini selanjutnya akan meningkatkan daya saing mebel dari dan akhirnya diharapkan akan lebih banyak lagi pembeli yang datang ke Jepara untuk membeli produknya dengan harga yang memadai. Pada akhirnya semua kemajuan ini akan meningkatkan kesejahteraan para pelaku industri kerajinan mebel berbahan baku kayu di Jepara.

Penulis bersama kepala Bappeda Kabupaten Jepara diundang untuk mengikuti peluncuran buku tentang kisah-kisah para aktor/pelaku industri mebel di Kabupaten Jepara sekitar pertengahan tahun 2011. Dalam sambutannya, pemimpin proyek FVC menyebutkan ada empat strategi yang dilakukan dalam proyek FVC untuk meningkatkan kinerja para perajin mebel berbahan baku kayu di Jepara yaitu: Pertama, strategi yang disebut moving up, yaitu yang bertujuan untuk meningkatkan status para perajin dari yang tadinya bersifat pasif menanti pembeli atau menunggu untuk produknya dibeli oleh para eksportir, menjadi naik satu tingkat menjadi 
eksportir yang punya akses pasar yang luas sehingga dapat meningkatkan kesejahteraannya.

Strategi ke dua, yaitu collaborating down, merupakan berupaya mendekatkan para perajin dengan penyedia bahan baku yaitu petani hutan. Strategi ini ditujukan agar para perajin mempunyai hubungan baik dengan pemasok bahan baku sehingga kontinuitas pasokan bahan baku bagi para perajin dapat terjamin.

Strategi yang ke tiga, yaitu green furniture mengupayakan agar para perajin dapat mengetahui seluk-beluk tentang produk mebel bersertifikasi yang akhir-akhir ini dipersyaratkan oleh para pembeli terutama di negara-negara Eropa dan Amerika. Strategi ini dimaksudkan agar para perajin dapat mengatasi hambatan perdagangan yang diterapkan oleh negara-negara tujuan ekspor.

Strategi yang ke empat, adalah pembentukan asosiasi perajin. Tujuannya adalah untuk meningkatkan kemampuan para perajin dalam berkelompok, berorganisasi, dan memecahkan bersama permasalahan-permasalahan yang mereka jumpai dalam mengelola usahanya. Masalah utama yang telah diketahui berupa masalah bahan baku, permodalan, produksi, dan pemasaran.

Semua strategi tersebut telah dilakukan dalam proyek FVC ini. Strategi pertama misalnya, para perajin telah dibantu untuk dapat menembus akses pasar dengan keikutsertaan dalam pameran-pameran dan penyediaan website untuk mempromosikan produk-produknya. Tentunya tindakan-tindakan ini merupakan tindakan awal yang harus dilanjutkan karena menurut informasi yang saya ketahui, proyek FVC akan berakhir tahun 2013. Untuk selanjutnya, para pelaku industri mebel sendirilah yang harus melanjutkan dan mengembangkan kegiatan-kegiatan yang memang dirasa tepat dan telah dirasakan manfaatnya oleh para perajin.

Strategi lainnya, yaitu collaborating down, telah dilakukan dengan melibatkan asosiasi pedagang kayu dalam proyek ini, yang juga didukung melalui upaya menanam Jati Unggul Nusantara (JUN) di pekarangan-pekarangan 
para perajin. Kemudian strategi green furniture dilaksanakan dengan mengikutsertakan para perajin dalam pelatihan-pelatihan, lokakarya, maupun seminar-seminar tentang bagaimana mengurus sertifikasi.

Terakhir, strategi yang ke empat, telah berhasil dibentuk asosiasi yang mewadahi para perajin untuk berupaya memecahkan permasalahanpermasalahan dalam pengelolaan usahanya yang dinamakan APKJ. Organisasi yang relatif masih baru ini tentunya masih minim pengalaman dan menurut saya sangat penting bagi APKJ untuk bekerja sama dengan organisasi lainnya di Jepara yang mempunyai bidang garap yang sama. Untuk menjalankan roda organisasi tidaklah mudah. Dengan keterbatasan sumber daya manusia yang dimiliki perajin, bukanlah hal yang mudah bagi mereka untuk terus mempertahankan eksistensinya. Saat ini mungkin masih ada CIFOR yang mendampingi untuk sementara waktu. Untuk itulah para perajin harus menyiapkan diri dan bekerja sama dengan pihak lain seperti pemerintah, LSM, asosiasi sejenis, dan sebagainya.

Dari uraian di atas, saya menarik kesimpulan bahwa keberadaan proyek FVC di Jepara telah banyak membantu para perajin dalam upayanya meningkatkan kualitas dalam pengelolaan usahanya. Namun demikian, dasar-dasar yang sudah diletakkan oleh proyek FVC dalam upaya pengembangan industri kerajinan mebel berbahan baku kayu ini tidak boleh berhenti setelah proyek FVC ini berakhir. Adalah tugas semua pemangku kepentingan untuk terus-menerus berupaya meningkatkan kemampuan industri ini dalam meningkatkan kualitasnya, yang akhirnya akan bermuara pada peningkatan akses pemasaran dan kesejahteraan para pelaku industri kerajinan berbahan baku kayu.

Saat ini yang kita perlukan adalah kerja sama. Saya yakin dengan bekerja sama seberat apapun masalah yang dihadapi dalam pengembangan industri kerajinan berbahan baku kayu akan dapat diatasi. Semoga saja apa yang telah dihasilkan dalam proyek FVC ini tidak hanya berjalan sebatas pelaksanaan proyek saja, tetapi dapat dilanjutkan dan dikembangkan dalam upayanya bagi Kabupaten Jepara untuk kembali meraih kejayaan sebagai produsen mebel berbahan baku kayu yang berkualitas. 


\subsection{Beberapa hal yang dapat menjadi inspirasi dan yang harus dihindari}

Setiap manusia pasti ingin sukses dalam hidupnya, tetapi untuk mencapai kesuksesan tidaklah semudah membalik telapak tangan. Sering kita jumpai orang telah berjuang dengan segala daya dan upaya dan telah bekerja keras, tetapi kesuksesan belum juga menghampirinya atau nasib belum berpihak kepadanya.

Penulis sebagai aparatur pemerintah yang bekerja di Bappeda saat itu ikut terlibat dengan kegiatan CIFOR untuk mengangkat perajin kecil di Jepara melalui proyek FVC. Ketika kegiatan ini diluncurkan mungkin banyak yang skeptis dan bertanya apakah mungkin perajin kecil yang banyak memiliki keterbatasan dapat menjadi pengusaha (enterpreneur) handal yang dapat menembus kerasnya persaingan di dunia industri mebel.

Namun dengan berjalannya waktu, setelah kegiatan proyek FVC ini berjalan lima tahun ternyata hasilnya luar biasa. Paling tidak ada lembaga yang menjadi embrio dari perajin kecil untuk bersama-sama maju, yaitu terbentuknya asosiasi perajin kecil yang bernama APKJ yang bisa dijadikan wahana para perajin untuk memecahkan berbagai masalah secara bersama. Tentunya waktulah yang akan menjawab apakah embrio ini bisa berkembang dengan baik menjadi lembaga yang tangguh bagi para perajin untuk memajukan usahanya.

Berkenaan dengan hal tersebut menurut pendapat penulis ada beberapa hal yang seharusnya dilakukan bila kita ingin maju dan mencapai sukses yaitu:

1. Jangan pernah menyerah dengan keadaan yang sedang dihadapi, sekalipun teramat sulit. Ada baiknya kita berupaya memecahkan masalah yang sedang kita hadapi dengan usaha keras sampai titik darah penghabisan;

2. Bekerja bersama dalam memecahkan persoalan akan jauh lebih baik daripada bekerja sendiri-sendiri; 
3. Membina hubungan baik dengan berbagai macam orang dengan latar belakang pengetahuan yang berbeda akan dapat meningkatkan pengetahuan dan wawasan kita dalam menghadapi persoalan hidup.

Di samping itu juga ada beberapa hal yang harus dihindari untuk mencegah kita dari kegagalan dalam mencapai sukses yaitu:

1. Terlalu percaya diri, sehingga dalam mengambil keputusan hanya mengandalkan pendapat diri sendiri tanpa mendengarkan saran orang lain sebagai bahan pertimbangan;

2. Terlalu cepat menyerah dalam memecahkan masalah, padahal belum seluruh daya upaya dilaksanakan;

3. Kurang membina hubungan dengan banyak orang dengan latar belakang pengetahuan dan wawasan yang berbeda.

Demikianlah beberapa hal yang mungkin bisa menjadi renungan bagi pembaca untuk dijadikan sebagai bahan dalam mencapai sukses. Semoga bermanfaat. 


\section{Bab 7. \\ Hikmah dan pengalaman berharga}

Perjalanan hidup dan pengalaman para pelaku usaha mebel di Jepara memberikan pelajaran dan hikmah bagi perbaikan di masa mendatang. Kesalahan di masa lalu janganlah dijadikan penyesalan, namun dijadikan guru yang paling berharga dalam menyongsong masa depan yang lebih cerah.

Kegiatan yang memberi manfaat harus terus dikembangkan dan disebarluaskan kepada khalayak yang lebih luas untuk diambil manfaatnya. Kesuksesan yang telah diraih saat ini bukanlah akhir dari perjalanan, tetapi menjadi awal yang baru bagi perjalanan selanjutnya. Karena itu, hal-hal yang baik dan berguna bagi bagi banyak pihak harus terus dilanjutkan, yang akan membantu para pelaku industri mebel untuk menggapai cita-citanya yaitu untuk meningkatkan taraf penghidupannya, melestarikan industri mebel Jepara, serta melestarikan budaya dan menyeimbangkan hubungan jender.

Ketekunan dalam berusaha, bekerja, dan pantang berputus-asa merupakan kebiasaan yang sudah dimiliki oleh sebagian masyarakat Jepara pelaku industri mebel, seperti yang tercermin dalam cerita mereka dalam buku ini. Memulai wirausaha bukan hanya mengandalkan bakat bisnis, namun juga keberanian dan pemikiran yang kreatif untuk selalu berkreasi dan berkarya demi kemajuan. Selain itu, untuk mewujudkan sebuah usaha yang berhasil diperlukan ketekunan, ketangguhan, kesabaran, dan yang terpenting setelah berusaha adalah memasrahkan diri kepada Tuhan YME. 
Memahami konsumen dan selera mereka adalah hal yang penting dalam semua bisnis. Strategi yang tepat perlu dilakukan para pelaku industri mebel Jepara untuk terus melangkah maju dan berkembang. Berkarya dalam bidang mebel seakan sudah menjadi keharusan bagi masyarakat Jepara, baik laki-laki maupun perempuan. Sementara keinginan untuk mandiri dan berwirausaha merupakan cita-cita mulia yang ingin dicapai oleh semua aktor yang terlibat dalam penulisan ini. Berganti profesi atau jenis pekerjaan seperti kisah beberapa perajin dalam buku ini, bukanlah sesuatu yang diharamkan. Sikap tetap konsisten berusaha dan mencapai yang terbaik bagi diri dan keluarga serta berusaha mewujudkan mimpi merupakan pelajaran berharga yang bisa didapatkan dari kisah para perajin.

Ketangguhan perempuan Jepara tidak berakhir dengan meninggalnya R.A Kartini, seorang tokoh emansipasi wanita Indonesia. Kedigdayaan perempuan Jepara tempo dulu tetap dilanjutkan dalam dunia mebel saat ini. Banyak perempuan yang bekerja keras, tanpa menghiraukan kelembutan tangannya yang menjadi kasar, demi mencapai cita-cita dan meningkatkan penghidupan bagi diri serta keluarganya. Ada pepatah bahwa "a strong woman stand up for herself but a stronger woman stand up for everybody else" yang jika diterjemahkan menjadi wanita yang kuat hanya berdiri untuk dirinya sendiri, tetapi wanita yang lebih kuat, berdiri demi orang lain. Hal inilah yang selalu tercermin dalam setiap cerita perjuangan perempuan Jepara baik di masa lalu (Ratu Shima, Ratu Kalinyamat, dan RA. Kartini) maupun di masa sekarang yang diperjuangkan oleh perempuan-perempuan perkasa pekerja industri mebel di Jepara. Sudah sepantasnyalah keterlibatan perempuan dalam industri mebel terus ditingkatkan dalam keseluruhan rantai nilai mebel dan dukungan dari seluruh pihak terkait akan keterlibatan perempuan juga lebih dimaksimalkan.

Industri mebel Jepara pernah mengalami kejayaan yang begitu hebat karena dampak dari situasi perekonomian saat itu. Sayangnya kejayaan ini surut kembali akibat perilaku pelaku usaha yang kurang profesional karena mendadak terjun ke industri ini tetapi tidak bisa mempertahankan kualitas produk dan komitmen terhadap pembeli. Kemampuan pelaku usaha mebel dalam membuat produk yang berkualitas dan sesuai dengan harga yang 
ditawarkan akan menjadi salah satu kunci keberhasilan industri mebel Jepara di masa mendatang.

Pemerintah Kabupaten Jepara juga terus berupaya untuk memajukan usaha kerajinan mebel ukir yang menyerap banyak tenaga kerja dan menjadi tulang punggung perekonomian masyarakat Jepara ini. Upaya ini terutama dalam menjaga kontinuitas pasokan bahan baku, pembinaan kepada perajin untuk meningkatkan kualitas produk sampai upaya menembus pasar luar negeri melalui keikutsertaan pameran di dalam dan luar negeri.

Bersosialisasi dan berorganisasi membuat wawasan dan khasanah perajin makin terbuka sehingga tidak terpaku pada pemikiran sendiri yang selama ini dijalani. Dengan mengenal banyak orang dan bekerja bersama banyak orang dari latar belakang keilmuan dan keahlian yang beragam, telah menambah kemampuan dalam melaksanakan tugas dan pekerjaan di kehidupan sehari-hari.

Perbedaan cara pendataan hendaknya jangan dijadikan perdebatan namun menjadi salah satu penambah wawasan bagi para pihak terkait dalam melakukan analisis kebijakan dan pemikiran terkait kemajuan industri mebel Jepara. Data yang dikumpulkan oleh CIFOR melalui proyek FVC merupakan sumber yang berharga untuk melengkapi lembaga resmi di Kabupaten Jepara yang bertugas membina industri mebel seperti Bappeda, Dinas Perindustrian dan Perdagangan, dan pihak terkait lainnya.

Mengukir bukan hanya sebuah profesi unggul yang diwarisi oleh masyarakat Jepara, tetapi sudah merupakan budaya, branding, dan jati diri masyarakatnya. Bekerja di luar Jepara dengan keterampilan mengukir yang dimiliki, selain demi tujuan mencari nafkah bagi diri dan keluarga juga membawa nama dan budaya ukir yang melekat dalam diri.

Membentuk kelompok sebagai wadah untuk berkumpul dan bersatu agar dapat menyalurkan aspirasi perajin mebel dalam meningkatkan produk dan pemasarannya merupakan langkah yang baik demi kemajuan bersama. 
Meninggalkan keegoisan diri dan kepentingan pribadi merupakan kunci keberhasilan berjalannya sebuah kelompok atau organisasi.

Koperasi merupakan bentuk badan usaha yang banyak bermanfaat bagi banyak orang. Salah satu manfaatnya adalah dalam sisi permodalan yang selalu menjadi masalah bagi para perajin mebel di Jepara. Selain itu koperasi juga dapat mengurangi persaingan tidak sehat yang sering terjadi di antara para perajin dalam memasarkan mebel. Mengorbankan mutu demi harga yang murah dapat merusak citra produk mebel Jepara.

Kebanyakan usaha kecil mebel dikelola secara kekeluargaan dengan pola tradisional tanpa sistem manajemen yang tercatat baik, terutama dari sisi keuangan usaha. Penyelenggaraan tata usaha, dari sisi produksi dan niaga mebel, perlu pemahaman dan cara-cara manajemen bisnis yang baik dalam rangka menghadapi persaingan usaha yang makin ketat. Selain itu, kualitas produk yang dibuat juga harus sesuai dengan spesifikasi yang disepakati dengan pembeli. Jika komitmen dengan pembeli tidak bisa dipertahankan, maka akan sulit untuk meraih kepercayaan lagi.

Berpikir kreatif dan selalu ingin maju dalam segala hal, menjadi modal utama dalam meningkatkan kemampuan diri. Perajin mebel harus selalu belajar dan mengenal hal-hal baru yang bisa didapatkan dari pelatihan, berkumpul dalam organisasi, melalui internet, dan cara-cara lain untuk dimanfaatkan bagi peningkatan kesejahteraan mereka.

Sikap perajin haruslah tangguh dan mempunyai komitmen untuk terus membesarkan usahanya. Persaingan di dunia usaha tidak hanya membutuhkan modal secara finansial namun juga membutuhkan ketangguhan dan jiwa kreativitas untuk bertahan. Pengembangan usaha membutuhkan komitmen yang kuat untuk berhasil. Semua usaha harus dilakukan untuk menggapai mimpi yang sudah tergores. Keyakinan bahwa setiap usaha akan memberikan hasil harus terus didengungkan dalam hati tanpa menyalahkan keadaan jika yang terjadi tidak atau belum sesuai harapan. 
Kesediaan untuk selalu menyesuaikan diri dengan keadaan pasar yang senantiasa berubah menurut waktu tentu perlu sekali. Kondisi eksternal usaha seperti ekonomi, politik, teknologi, sosial budaya dan perundangan dapat berganti setiap waktu. Persaingan yang makin lama makin ketat mengharuskan setiap pelaku usaha memiliki VRIO yaitu Valuable atau sesuatu yang berharga dan bermanfaat yang bisa ditawarkan ke pasar; Rareness yaitu kelangkaan atau sesuatu yang hanya dimiliki oleh pelaku usaha itu sendiri; Inimitability yaitu sesuatu yang tidak bisa ditiru oleh pesaing; dan Organisational yaitu pengorganisasian usaha yang baik. 

Riset aksi (action research) untuk meningkatkan efisiensi rantai nilai dan meningkatkan penghidupan perajin mebel (Furniture Value Chains atau FVC) adalah sebuah proyek penelitian yang didanai oleh Pusat Penelitian Pertanian Internasional Australia (Australian Centre for International Agricultural Research atau ACIAR) yang dilaksanakan oleh CIFOR, Badan Penelitian dan Pengembangan Kehutanan Departemen Kehutanan (Balitbanghut), dan Institut Pertanian Bogor (IPB) sejak tahun 2008 hingga tahun 2013. Tujuan utama dari riset ini adalah untuk mengupayakan terciptanya perbaikan struktur dan fungsi industri mebel Jepara, dari perolehan bahan baku kayu hingga proses pemasaran ke konsumen.

Peran para aktor lokal sangat penting dalam pelaksanaan riset aksi. Mereka sudah sekian lama berkutat dalam dinamika industri mebel dan tetap berusaha meski jatuh bangun dalam mengembangkan industrinya. Buku ini menceritakan pengalaman pribadi para pelaku industri mebel yang terdiri dari perajin laki-laki, perempuan serta pengambil kebijakan. Cerita-cerita ini memberikan perspektif nyata bahwa industri mebel tidak cukup hanya mengandalkan bakat bisnis semata, namun juga keberanian dan keterbukaan pemikiran yang kreatif untuk selalu berkreasi dan berkarya demi kemajuan.

\section{cifor.org/furniture}

\begin{tabular}{|c|c|c|}
\hline CGIAR & $\begin{array}{l}\text { RESEARCH } \\
\text { PROGRAM ON } \\
\text { Forests, Trees and } \\
\text { Agroforestry }\end{array}$ & $\begin{array}{l}\text { Penelitian ini dilaksanakan oleh CIFOR sebagai bagian dari Program } \\
\text { Penelitian CGIAR pada Hutan, Pohon dan Wanatani (CRP-FTA). } \\
\text { Program kolaboratif ini bertujuan untuk meningkatkan pengelolaan } \\
\text { dan pemanfaatan hutan, wanatani, dan sumber daya genetis pohon } \\
\text { yang mencakup lanskap dari hutan sampai ke lahan budidaya. } \\
\text { CIFOR memimpin CRP-FTA melalui kemitraan dengan Bioversity } \\
\text { International, CIRAD, International Center for Tropical Agriculture dan } \\
\text { World Agroforestry Centre. }\end{array}$ \\
\hline
\end{tabular}

\section{cifor.org}
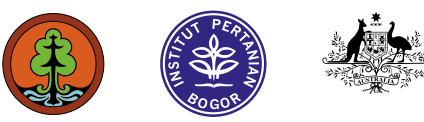
melalui penelitian yang membantu membentuk kebijakan dan praktik kehutanan di negara berkembang. CIFOR adalah anggota Konsorsium CGIAR. Kantor pusat kami berada di Bogor, Indonesia, dengan kantor wilayah di Asia, Afrika dan Amerika Selatan. 